
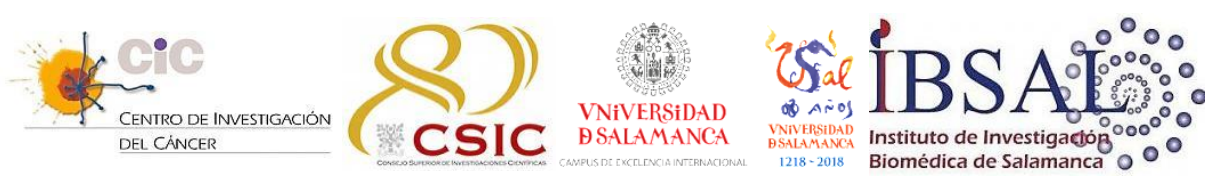

CENTRO DE INVESTIGACIÓN DEL CÁNCER

INSTITUTO DE BIOLOGÍA MOLECULAR Y CELULAR DEL CÁNCER

(CSIC-USAL)

\title{
NUEVAS FUNCIONES DE LA QUINASA HUMANA VRK1 EN LA RESPUESTA AL DAÑO EN EL ADN Y LA ESTRUCTURA DE LA CROMATINA
}

TESIS DOCTORAL

Ignacio Campillo Marcos

Salamanca, España 


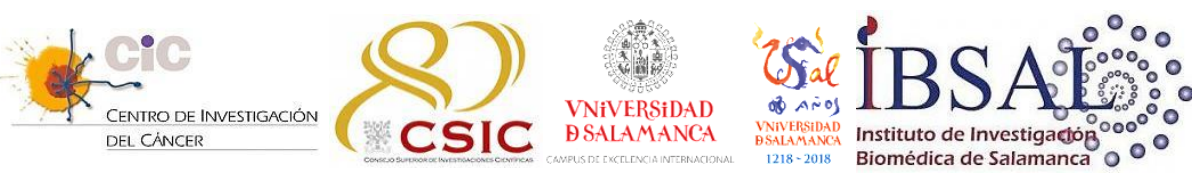

D. Pedro A. Lazo-Zbikowski Taracena, Profesor de Investigación del Consejo Superior de Investigaciones Científicas (CSIC),

\section{CERTIFICA:}

Que la memoria titulada "NUEVAS FUNCIONES DE LA QUINASA HUMANA VRK1 EN LA RESPUESTA AL DAÑO EN EL ADN Y LA ESTRUCTURA DE LA CROMATINA", presentada por el licenciado en biotecnología Ignacio Campillo Marcos, ha sido realizada bajo su dirección en el Instituto de Biología Molecular y Celular del Cáncer y reúne, a su juicio, originalidad y contenidos suficientes para ser presentada ante el tribunal correspondiente y optar al grado de doctor por la Universidad de Salamanca.

Y para que así conste a efectos legales, expide el presente certificado en Salamanca, a 14 de junio de 2019.

Fdo. Pedro A. Lazo-Zbikowski Taracena 

Esta memoria ha sido realizada siendo IGNACIO CAMPILLO MARCOS beneficiario de un contrato predoctoral para la formación de doctores contemplado en el Subprograma Estatal de Formación del Programa Estatal de Promoción del Talento y su Empleabilidad, en el marco del Plan Estatal de Investigación Científica y Técnica y de Innovación 2013-2016 (Referencia: BES-2014-067721) (2015-2019).

La investigación en el laboratorio ha sido financiada por los siguientes proyectos:

Ministerio de Economía y Competitividad (SAF2013-44810R)

Ministerio de Economía y Competitividad (SAF2014-57791-REDC)

Junta de Castilla y León, Consejería de Educación (CSI002U14)

Junta de Castilla y León, Consejería de Educación (CSI001U16)

Ministerio de Economía y Competitividad, Agencia Estatal de Investigación (SAF201675774R) 



\section{TABLA DE CONTENIDO}

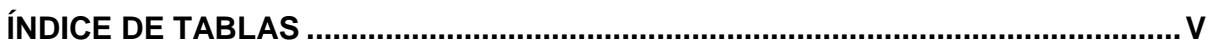

ÍNDICE DE FIGURAS....................................................................................... VII

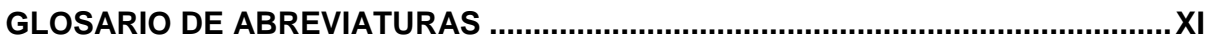

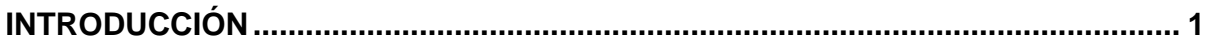

1. Cromatina: Estructura y función................................................................ 3

1.1 Estructura de los nucleosomas ....................................................... 3

1.1.1 Variantes de histonas en el nucleosoma ........................................... 5

1.2 Moduladores de la estructura de la cromatina........................................... 6

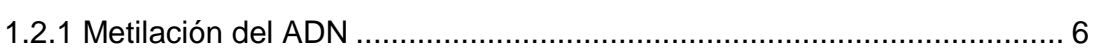

1.2.2 Posicionamiento de los nucleosomas ................................................. 6

1.2.3 Modificaciones covalentes de histonas............................................... 9

1.3 Cambios en la cromatina asociados a procesos celulares ....................... 11

1.3.1 Modificación de la cromatina en replicación ........................................ 11

1.3.2 Modulación de la estructura de la cromatina durante la transcripción .. 13

1.3.3 Cambios en la cromatina asociados a la reparación del ADN .............. 16

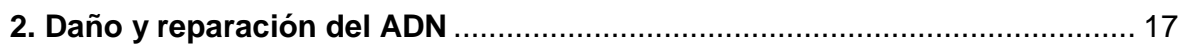

2.1 Agentes causantes de daño en el ADN............................................... 18

2.1.1 Procesos celulares endógenos causantes de daño génico .................. 18

2.1.2 Agentes exógenos causantes de daño en el ADN.............................. 19

2.2 Reparación de las roturas de cadena sencilla (SSBs) .............................. 20

2.2.1 Reparación directa o in situ ......................................................... 20

2.2.2 Reparación por escisión de bases ..................................................... 20

2.2.3 Reparación por escisión de nucleótidos ............................................ 21

2.2.4 Reparación de apareamientos erróneos o mismatch repair (MMR)...... 21

2.3 Reparación de las roturas de doble cadena (DSBs) ............................... 22

2.4 Cambios en la estructura de la cromatina y dinámica de formación de focos

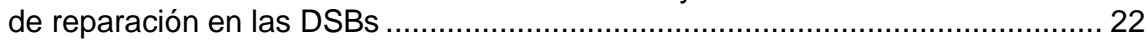

2.4.1 Reconocimiento del daño y activación de las proteínas sensoras ........ 23

2.4.2 Reclutamiento de las proteínas mediadoras: selección del mecanismo de reparación ......................................................................................... 25

2.4.3 Vías de reparación de DSBs: recombinación homóloga $(H R)$ y unión de extremos no homólogos (NHEJ) .............................................................. 32

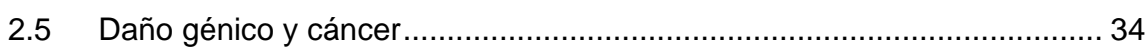

2.5.1 Inhibidores de PARP en el tratamiento del cáncer............................... 35

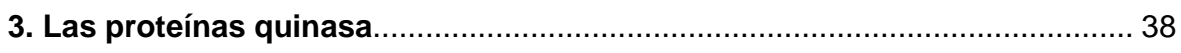

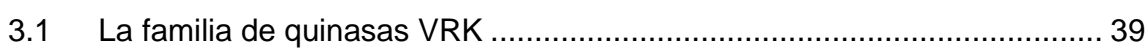

3.2 Estructura de las quinasas VRK ..................................................... 40 


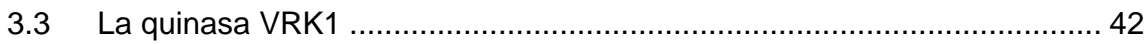

3.3.1 Localización subcelular de VRK1 ................................................ 42

3.3.2 Papel de VRK1 en proliferación y progresión del ciclo celular .............. 43

3.3.3 Importancia de VRK1 en el ensamblaje de la envuelta nuclear ............ 43

3.3.4 VRK1 en la fragmentación del aparato de Golgi .................................. 44

3.3.5 Regulación de factores de transcripción mediada por VRK1 ............... 44

3.3.6 VRK1 y la fosforilación de histonas................................................... 45

3.3.7 La quinasa VRK1 en la respuesta al daño génico ............................. 47

3.3.8 Implicación de VRK1 en cáncer .......................................................... 49

3.3.9 VRK1 y las enfermedades neurodegenerativas.................................. 49

3.3.10 Ratones knock-out para VRK1 ................................................... 51

3.3.11 Regulación de la quinasa VRK1 ................................................ 51

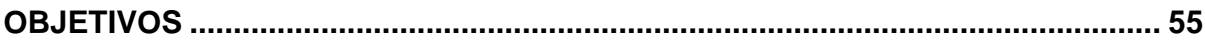

MATERIALES Y MÉTODOS ................................................................................ 57

1. Técnicas de manipulación de proteínas...................................................... 59

1.1 Obtención de extractos proteicos de células en cultivo ............................ 59

1.2 Extracción ácida de histonas............................................................... 59

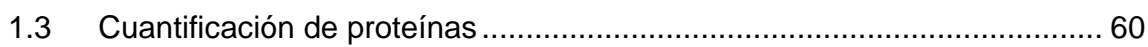

1.4 Electroforesis en geles SDS-PAGE .................................................. 60

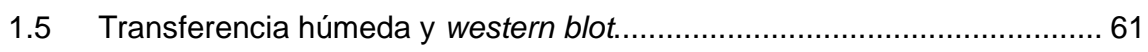

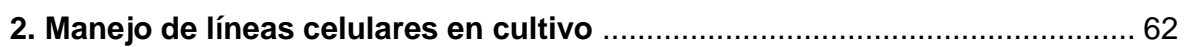

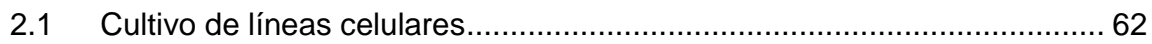

2.2 Supresión de la expresión génica mediante ARNi .................................. 63

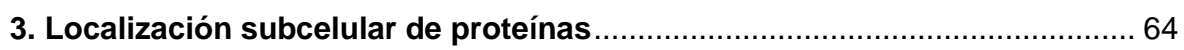

3.1 Inmunofluorescencia y microscopía confocal ....................................... 64

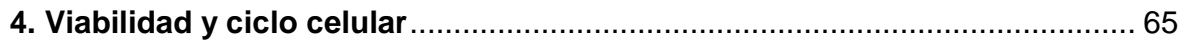

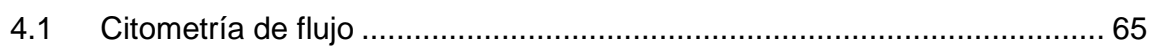

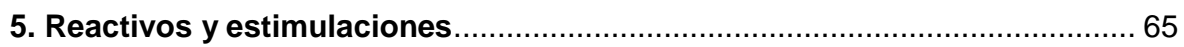

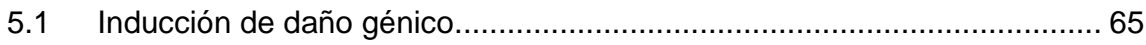

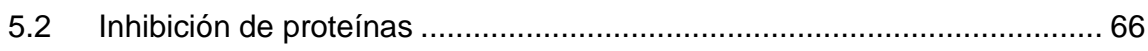

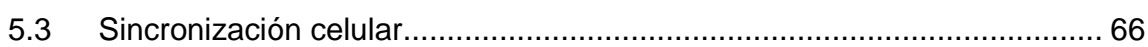

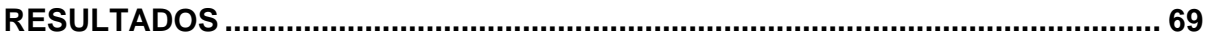

1. Papel de VRK1 en la respuesta al daño en el ADN causado por la combinación de olaparib y radiación ionizante ................................................. 71

1.1 El olaparib sensibiliza a las células tumorales al daño génico inducido por

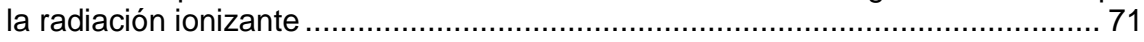

1.2 El olaparib sensibiliza a las líneas celulares tumorales que carecen de TP53 al tratamiento con radiación ionizante. 74 
1.3 El silenciamiento de VRK1 afecta significativamente a la respuesta al daño en el ADN inducida por olaparib e IR, y es independiente de p53........................ 76

1.4 La ausencia de suero en el medio de cultivo ralentiza la tasa de crecimiento de las células tumorales 81

1.5 El silenciamiento de VRK1 interfiere en la acetilación de la histona $\mathrm{H} 4$ en la lisina 16 inducida por olaparib e IR. 82

1.6 La respuesta al daño en el ADN causada por olaparib, IR o su combinación mediada por NBS1 se ve afectada en ausencia de VRK1 86

1.7 El silenciamiento de VRK1 interfiere en la respuesta al daño en el ADN inducida por el tratamiento con olaparib, IR o su combinación en células en reposo.

1.8 El efecto del silenciamiento de $V R K 1$ sobre la respuesta al daño génico inducido por olaparib y/o IR es independiente de p53 y ATM en células sin suero $(0,5 \%)$

1.9 La inhibición de ATM mimetiza el efecto del silenciamiento de VRK1 sobre la formación de focos de $\mathrm{YH} 2 \mathrm{AX}$ y 53BP1 en respuesta a olaparib 101

1.10 El silenciamiento de VRK1, pero no la inhibición de ATM, interfiere en la acetilación de la H4K16 asociada al tratamiento con olaparib. 103

2. Efecto del inhibidor chaetocin en la regulación del ciclo celular y la respuesta al daño en el ADN. 106

2.1 Los cambios en la metilación de la cromatina alteran el perfil de ciclo celular sin modificar la viabilidad 106

2.2 El inhibidor chaetocin es capaz de inducir daño en el ADN por sí mismo, pero no muestra efectos sinérgicos con la radiación ionizante. 109

2.3 La inhibición de la metilación asociada al tratamiento con chaetocin impide la correcta formación de focos de 53BP1 tras la inducción de daño con IR .......110

2.4 El inhibidor chaetocin impide la formación de focos de 53BP1 asociada al tratamiento con olaparib 114

2.5 El efecto del inhibidor chaetocin sobre la formación de focos de 53BP1 no depende del tiempo transcurrido desde la irradiación 116

2.6 La inhibición de la metilación asociada al tratamiento con chaetocin no modifica el reclutamiento de otras proteínas implicadas en la reparación de las DSBs generadas por IR 119

2.7 La pérdida de la acetilación de la histona $\mathrm{H} 4$ en la lisina 16 no interfiere en la formación de focos de 53BP1 en respuesta a IR. 121

2.8 El inhibidor chaetocin reduce los niveles de la dimetilación de la histona $\mathrm{H} 4$ en la lisina 20 e, indirectamente, favorece la acetilación de la H4K16 .............. 123

3. Implicación de la quinasa humana VRK1 en la regulación de las modificaciones covalentes de las histonas $\mathrm{H} 3$ y $\mathrm{H} 4$ 126

3.1 Efecto del silenciamiento de VRK1 sobre la acetilación de la lisina 16 de la histona $\mathrm{H} 4$. 126

3.1.1 La inhibición de las deacetilasas de histonas compensa el efecto del silenciamiento de VRK1 sobre la H4K16ac 128

3.1.2 La disminución de los niveles de la H4K16ac en ausencia de VRK1 es comparable al efecto que tiene el inhibidor MG149 sobre esta acetilación . 129 
3.2 La ausencia de VRK1 altera el patrón de metilación de la lisina 4 de la histona $\mathrm{H} 3$.

3.2.1 La inhibición de la metilación mediada por chaetocin mimetiza el efecto

de la ausencia de VRK1 sobre la H3K4me3 133

3.3 El silenciamiento de VRK1 modifica la dinámica de acetilación/metilación de la lisina 9 de la histona $\mathrm{H} 3$ 134

3.3.1 Los niveles de acetilación de la H3K9 aumentan tras el tratamiento con inhibidores de deacetilasas en presencia y ausencia de VRK1 136

3.3.2 El silenciamiento de VRK1 reduce los niveles de acetilación de la H3K9 de manera similar a los inhibidores de HATs. 138

3.3.3 La inhibición de las demetilasas mediada por JMJD2i mimetiza el efecto del silenciamiento de VRK1 sobre la trimetilación de la H3K9. 140

1. Papel de VRK1 en la respuesta al daño en el ADN causado por la combinación de olaparib y radiación ionizante. 145

1.1 El olaparib sensibiliza a las células cancerosas al tratamiento con radiación ionizante y genera una respuesta independiente de p53 146

1.2 La quinasa VRK1 regula la respuesta al daño génico derivada del tratamiento con olaparib e IR..... 147

1.3 El desarrollo de inhibidores de VRK1 para su utilización en tratamientos combinados con olaparib e IR ..... 151

2. Efecto del inhibidor chaetocin en la regulación del ciclo celular y la respuesta al daño en el ADN 154

2.1 Consecuencias del tratamiento con los inhibidores chaetocin y JMJD2i sobre la regulación del ciclo celular ........................................................... 154

2.2 Implicación del inhibidor chaetocin en la respuesta al daño en el ADN .. 156

3. Implicación de la quinasa humana VRK1 en la regulación de las modificaciones covalentes de las histonas $\mathrm{H} 3$ y $\mathrm{H} 4$ 162

3.1 Cambios en la acetilación de la lisina 16 de la histona $\mathrm{H} 4$ asociados al silenciamiento de VRK1. 162

3.2 Regulación de la trimetilación de la lisina 4 de la histona H3 mediada por la quinasa VRK1 164

3.3 Cambios en la acetilación y trimetilación de la lisina 9 de la histona H3 mediados por VRK1 166

3.4 Modificación del patrón de acetilación/metilación de las histonas H3 y H4 como consecuencia del silenciamiento de VRK1 169

CONCLUSIONES 173 


\section{ÍNDICE DE TABLAS}

Tabla 1: Lista de aminoácidos y bases nitrogenadas con sus abreviaturas...... XVI

Tabla 2: Moduladores de la estructura de la cromatina implicados en replicación..... 13

Tabla 3: Descripción y principales características de las líneas celulares utilizadas.. 62

Tabla 4: Secuencias y uso de los oligonucleótidos empleados. 63

Tabla 5: Inhibidores de los distintos modificadores de histonas utilizados, señalando las dianas para las que fueron diseñados y las formas de uso de cada uno de ellos. 66 Tabla 6: Lista de anticuerpos primarios y secundarios empleados, indicando su correpondiente dilución para western blot (WB) y/o inmunofluorescencia (IF) .... 68 



\section{ÍNDICE DE FIGURAS}

Figura 1: Estructura esquemática de las histonas canónicas que forman el nucleosoma.

Figura 2: Familias de complejos remodeladores de cromatina dependientes de ATP. 8

Figura 3: Esquema que ilustra las principales modificaciones en las histonas que componen el nucleosoma durante las distintas etapas de la transcripción..... 15

Figura 4: Los sistemas de reparación del ADN participan activamente en la prevención del envejecimiento y de patologías como el cáncer

Figura 5: Esquema representativo de las principales modificaciones en la cromatina y de las proteínas implicadas en la respuesta al daño en el ADN que participan en el reclutamiento de BRCA1 o 53BP1 28

Figura 6: Esquemas representativos de los dos principales mecanismos de reparación de roturas de doble cadena, unión de extremos no homólogos (NHEJ) y recombinación homóloga (HR)

Figura 7: Estructura de PARP1 y su implicación en distintas respuestas celulares... 36

Figura 8: Representación esquemática del quinoma humano 38

Figura 9: Estructura esquemática de las quinasas VRK, indicando los principales motivos y dominios, y el porcentaje de homología entre los tres miembros de la familia

Figura 10: Principales sustratos de la quinasa humana VRK1, indicando los residuos fosforilados en cada caso

Figura 11: Estructura de la quinasa humana VRK1 en la que aparecen señaladas las distintas mutaciones asociadas a procesos neurodegenerativos y su localización en la proteína 50

Figura 12: Efecto del olaparib, la IR y su combinación sobre la formación de focos de YH2AX y 53BP1 en la línea celular MDA-MB-231.

Figura 13: Efecto del olaparib, la IR y su combinación sobre la formación de focos de YH2AX y 53BP1 en la línea celular A549 (TP53 +/+). 74

Figura 14: Efecto del olaparib, la IR y su combinación sobre la formación de focos de YH2AX y 53BP1 en la línea celular H1299 (TP53 -/-) 76 
Figura 15: El silenciamiento de VRK1 interfiere en la formación de focos de $\mathrm{yH} 2 \mathrm{AX}$ y 53BP1 tras la inducción de daño génico con olaparib y/o IR en la línea celular A549 $($ TP53 $+/+)$

Figura 16: El silenciamiento de VRK1 interfiere en la formación de focos de $\mathrm{yH} 2 \mathrm{AX}$ y 53BP1 tras la inducción de daño génico con olaparib y/o IR en la línea celular H1299 (TP53 -/-)

Figura 17: El crecimiento de las células tumorales A549 y H1299 se ralentiza al retirar el suero del medio de cultivo 82

Figura 18: La ausencia de VRK1 reduce significativamente la acetilación de la H4K16 tras el tratamiento con olaparib, IR o su combinación en células A549 $($ TP53 +/+) .... 84

Figura 19: El silenciamiento de VRK1 conlleva una disminución altamente significativa de la acetilación de la H4K16 tras el tratamiento con olaparib e IR por separado, o en combinación, en la línea celular H1299 (TP53 -/-).....

Figura 20: El silenciamiento de VRK1 reduce significativamente la acumulación de NBS1 en las zonas dañadas tras el tratamiento con olaparib, IR o su combinación en células A549 (TP53 +/+) 88

Figura 21: El efecto del silenciamiento de VRK1 sobre la formación de focos de NBS1 tras el tratamiento con olaparib, IR o su combinación no depende de ATM 90

Figura 22: La ausencia de VRK1 impide la formación de focos de NBS1 tras el tratamiento con olaparib, IR o su combinación en células H1299 (TP53 -/-) 91

Figura 23: La ausencia de VRK1 altera la formación de focos de $\mathrm{YH} 2 \mathrm{AX}$ y 53BP1 en respuesta al tratamiento con olaparib, IR o su combinación en células A549 sin suero $(0,5 \%)$ .94

Figura 24: El silenciamiento de VRK1 interfiere en la formación de focos de $\mathrm{yH} 2 \mathrm{AX}$ y 53BP1 en respuesta al tratamiento con olaparib, IR o su combinación en células en reposo carentes de p53 (H1299) 98

Figura 25: El efecto del silenciamiento de VRK1 sobre la formación de focos de $\mathrm{YH} 2 \mathrm{AX}$ y $53 \mathrm{BP} 1$ en respuesta al tratamiento con olaparib, IR o su combinación es independiente de ATM en células sin suero $(0,5 \%)$. 101

Figura 26: La inhibición de ATM mimetiza el efecto del silenciamiento de VRK1 sobre la formación de focos de $\mathrm{YH} 2 \mathrm{AX}$ y 53BP1 103

Figura 27: La ausencia de VRK1 conlleva una reducción significativa de los niveles de la H4K16ac en las células HT144 (ATM -/-). 104 
Figura 28: La inhibición de ATM no interfiere en la acetilación de la H4K16 en las células A549 105

Figura 29: Cambios en la trimetilación de la H3K9 tras el tratamiento con chaetocin o JMJD2i

Figura 30: El inhibidor de metiltransferasas chaetocin y el de demetilasas JMJD2i modifican el perfil de ciclo de las células U2OS sin alterar su viabilidad. 108

Figura 31: El inhibidor chaetocin induce daño en el ADN, pero no muestra un efecto sinérgico sobre la formación de focos de $\mathrm{YH} 2 \mathrm{AX}$ al combinarlo con IR 110

Figura 32: El inhibidor chaetocin impide la correcta formación de focos de 53BP1 tras la inducción de daño con IR sin modificar sus niveles proteicos 112

Figura 33: La inhibición de demetilasas mediada por JMJD2i no afecta a la formación de focos de $\mathrm{YH} 2 \mathrm{AX}$ y $53 \mathrm{BP} 1$ en respuesta a IR 113

Figura 34: El inhibidor chaetocin impide la correcta formación de focos de 53BP1 tras el tratamiento con olaparib 115

Figura 35: El tratamiento con el inhibidor de demetilasas JMJD2i no altera la formación de focos de 53BP1 en respuesta a olaparib. 116

Figura 36: El tratamiento con chaetocin impide la correcta formación de focos de 53BP1 independientemente del tiempo transcurrido desde la irradiación 118

Figura 37: La inhibición de la metilación mediada por chaetocin no afecta ni a la formación de focos de NBS1 y MDC1 ni a sus niveles proteicos. 121

Figura 38: La inhibición de Tip60 mediada por MG149 reduce significativamente los niveles de H4K16ac, pero no interfiere en la formación de focos de 53BP1 122

Figura 39: El inhibidor chaetocin reduce considerablemente los niveles de H4K20me2 en respuesta al daño génico inducido por IR 124

Figura 40: La acetilación de la H4K16 aumenta en respuesta al daño inducido con IR, pero no varía en presencia o ausencia de chaetocin. 125

Figura 41: El silenciamiento de VRK1 reduce significativamente los niveles de la H4K16ac

Figura 42: Los inhibidores entinostat y SAHA promueven un aumento significativo de los niveles de la H4K16ac que no depende de la presencia o ausencia de VRK1 ... 129 Figura 43: El inhibidor MG149 mimetiza el efecto de la ausencia de VRK1 sobre la H4K16ac 131 
Figura 44: El silenciamiento de VRK1 conlleva una disminución considerable de los niveles de la trimetilación de la H3K4 132

Figura 45: El silenciamiento de VRK1 y el tratamiento con el inhibidor chaetocin reducen significativamente los niveles de la $\mathrm{H} 3 \mathrm{~K} 4 \mathrm{me} 3$ 134

Figura 46: El silenciamiento de VRK1 conlleva el aumento de la metilación de la H3K9 y la disminución de la acetilación de este residuo 136

Figura 47: La inhibición de las deacetilasas mediada por entinostat y SAHA conlleva un aumento significativo de los niveles de la $\mathrm{H} 3 \mathrm{~K} 9 \mathrm{ac}$ 138

Figura 48: Tanto el silenciamiento de VRK1 como el tratamiento con los inhibidores C646 y MG149 reducen los niveles de acetilación de la H3K9. 140

Figura 49: La inhibición de las demetilasas mediada por JMJD2i muestra el mismo efecto sobre la trimetilación de la $\mathrm{H} 3 \mathrm{~K} 9$ que el silenciamiento de VRK1 142

Figura 50: Diagrama que muestra las distintas etapas de la respuesta al daño en el ADN inducida por IR y como se ven alteradas por inhibidores específicos de proteínas clave de la DDR 152

Figura 51: Esquema representativo del efecto de los inhibidores chaetocin y JMJD2i sobre el ciclo celular. 155

Figura 52: Modelo hipotético que muestra, por una parte, el reclutamiento de 53BP1 y su unión a la cromatina en respuesta al daño génico (izquierda) y, por otra, cómo la inhibición de la H4K20me2 mediada por chaetocin favorece, de manera indirecta, la acetilación de la H4K16 e impide la acumulación de 53BP1 en las DSBs y, en consecuencia, la correcta reparación del ADN (derecha). 160

Figura 53: Regulación de la acetilación de la H4K16 mediada por VRK1 164

Figura 54: Modelo hipotético de la regulación de las modificaciones covalentes en la lisina 4 de la histona $\mathrm{H} 3$ asociada a la quinasa VRK1 166

Figura 55: Cambios en la acetilación y la trimetilación de la H3K9 mediados por VRK1, indicando las enzimas que esta quinasa de la cromatina podría estar regulando 168

Figura 56: Efecto indirecto de los inhibidores de acetilasas/deacetilasas sobre la H3K9me3 y de los de metiltransferasas/demetilasas sobre la H3K9ac (representado con línea discontinua)..... 169

Figura 57: Cambios globales en el patrón de acetilación/metilación asociados al silenciamiento de VRK1. 170 
GLOSARIO DE

ABREVIATURAS

\section{A}

acetil-CoA: acetil-coenzima A

ADN: ácido desoxirribonucleico

ADNc: ADN codificantes

ADP: adenosine diphosphate

a-EJ: alternative end joining

AP: apurínico o apirimidínico

APS: ammonium persulfate

ARN: ácido ribonucleico

ARNi: ARN de interferencia

ARNm: ARN mensajero

ARN pol II: ARN polimerasa II

ARPs: actin-related proteins

ASF1a: anti-silencing factor $1 a$

ATF2: activating transcription factor 2

ATM: ataxia-telangiectasia mutated

ATR: ataxia-telangiectasia and Rad3 related protein kinase

ATP: adenosine triphosphate

\section{B}

BAB: dominio básico-ácido-básico

BAF: barrier-to-autointegration factor

BAFs: BRG1- associated factors

BARD1: BRCA1-associated RING domain protein 1
BER: base excision repair

BRCA1: breast cancer associated 1

BRD: bromodominio

BSA: bovine serum albumin

C

CB1N: ciclina B1 nuclear

CDKs: quinasas dependientes de ciclinas

CENP-A: histone H3-like centromeric protein $A$

CHD: chromodomain-helicase-DNA binding

CK1: casein kinase 1

CRE: cAMP-response element

CREB: CRE-binding protein

CSR: class-switch recombination

CtIP: CtBP interacting protein

D

DAPI: 4', 6'-diamidino-2-fenilindol

DBD: DNA-binding domain

DDR: DNA damage response

DMEM: Dulbecco's modified-minimum essential medium

DMSO: dimetil sulfóxido

DNA-PKcs: DNA-dependent protein kinase, catalytic subunit

DNMTs: DNA metiltransferases

DRAM: damage-regulated autophagy modulator 
DSBs: double-strand breaks

DTT: dithiothreitol

\section{E}

EDTA: ethylenediamine-tetraacetic acid

EP300: E1A-associated protein p300, familia CBP/p300

EST: expression sequences tags

$\mathbf{F}$

FAD: flavin adenine dinucleotide

FBS: fetal bovine serum

$\mathrm{Fe}^{2+}$ : ion hierro

G

g: fuerza de la gravedad

GDP: guanosine diphosphate

GG-NER: global genome NER

GNAT: GCN5-related Nacetyltransferase

GTP: guanosine triphosphate

Gy: Gray

\section{H}

H2A.Bbd: H2A Barr body deficient (o H2A.B)

H2AK15ub: ubiquitinación de la lisina 15 de la histona $\mathrm{H} 2 \mathrm{~A}$

H2AK119ub: ubiquitinación de la lisina 119 de la histona H2A
H2BFWT: histone H2B type WT (o H2B.W)

H2BK120ub: ubiquitinación de la lisina 120 de la histona H2B

H3K4ac: acetilación de la lisina 4 de la histona $\mathrm{H} 3$

H3K4me3: trimetilación de la lisina 4 de la histona $\mathrm{H} 3$

H3K9ac: acetilación de la lisina 9 de la histona $\mathrm{H} 3$

H3K9me2/3: di- y trimetilación de la lisina 9 de la histona $\mathrm{H} 3$

H3S10ph: fosforilación de la serina 10 de la histona $\mathrm{H} 3$

H3K14ac: acetilación de la lisina 14 de la histona $\mathrm{H} 3$

H3K27ac: acetilación de la lisina 27 de la histona $\mathrm{H} 3$

H3K27me2/3: di- y trimetilación de la lisina 27 de la histona $\mathrm{H} 3$

H3K36me3: trimetilación de la lisina 36 de la histona $\mathrm{H} 3$

H3K45ph: fosforilación de la lisina 45 de la histona $\mathrm{H} 3$

H3K79me2: dimetilación de la lisina 79 de la histona $\mathrm{H} 3$

H4S1ph: fosforilación de la serina 1 de la histona $\mathrm{H} 4$

H4R3me: metilación de la arginina 3 de la histona $\mathrm{H} 4$

$\mathrm{H} 4 \mathrm{~K}(5,8,12,16)$ ac: acetilaciones de las lisinas 5, 8, 12 y 16 de la histona $\mathrm{H} 4$

H4K16ac: acetilación de la lisina 16 de la histona $\mathrm{H} 4$

H4K20me1/2/3: mono-, di- y trimetilación de la lisina 20 de la histona $\mathrm{H} 4$

$\mathrm{H}_{2} \mathrm{O}_{2}$ : peróxido de hidrógeno 
HATs: acetiltransferasas 0 acetilasas de histonas

$\mathrm{HCl}$ : ácido clorhídrico

HDACs: deacetilasas de histonas

HDMs: demetilasas de histonas

HJ: Holliday junctions

HR: homologous recombination

HSA: helicase-SANT

I

IF: inmunofluorescencia

INO80: inositol requiring 80

IP: ioduro de propidio

IR: radiación ionizante

ISWI: imitation switch

J

JMJC: Jumonji C

JMJD2i: JMJD2 inhibitor

JNK: c-Jun N-terminal kinase

\section{K}

$\mathrm{KCl}$ : cloruro de potasio

kDa: kiloDalton

KDMs: demetilasas de lisinas

LSDs: demetilasas lisina-específicas

\section{M}

M: molar

macroH2A1.1: macrohistona H2A1.1

macroH2A2: macrohistona H2A2

MAPKs: mitogen-activated protein

kinases

MCM: minichromosome maintenance

MCPH1: microcephalin o BRIT1

MDC1: mediator of DNA damage

checkpoint protein 1

MEK1: mitogen-activated protein

kinase 1

mg: miligramo

$\mathrm{MgCl}_{2}$ : cloruro de magnesio

min: minuto

ml: mililitro

mm: milímetro

mM: milimolar

MMC: mitomicina C

MMS: metil-metanosulfonato

MNU: metil-nitrosurea

Mre11: meiotic recombination 11

MRN: Mre11-Rad50-NBS1

MYST: MOZ, Ybf2/Sas3, Sas2 y Tip60

\section{$\mathbf{N}$}

$\mathrm{N}$ : normal

$\mathrm{NaCl}$ : cloruro de sodio

$\mathrm{NAD}^{+}$: nicotinamide adenine dinucleotide 
NaF: fluoruro de sodio

NBS1: Nijmegen breakage syndrome 1

NER: nucleotide excision repair

NES: nuclear exportation signal ng: nanogramo

NHEJ: non-homologous end joining

NLS: nuclear localization signal

nm: nanómetro

nM: nanomolar

0

ORCs: origin recognition complexes

$\mathbf{P}$

PARP: poly-ADP ribose polymerase

PBAF: polybromo-associated BAF

PBS: phosphate buffer salinum

PCNA: proliferating cell nuclear antigen

PIC: complejo de pre-iniciación

PIKK: phosphoinositole 3-kinase-like kinases

PKCס: proteína quinasa Cঠ

PKMTs: protein lysine

methyltransferases

Plk1: polo-like kinase 1

Plk3: polo-like kinase 3

PMSF: phenyl methyl sulfonyl fluoride

pre-RC: pre-replication complex
PRC1: complejo represor Polycomb 1

PRMTs: protein arginine methyltransferases

\section{$\mathbf{R}$}

Ran: Ras-related nuclear

$\mathrm{Rb}$ : retinoblastoma

RIPA: radio immunoprecipitation assay

ROS: reactive oxygen species

RPA: replication protein $A$

rpm: revoluciones por minuto

RPMI: Roswell Park Memorial Institute

\section{S}

SAGA: Spt-Ada-GCN5 acetyltransferase

SAHA: suberoylanilide hydroxamic acid

SAM: S-adenosil-metionina

SDS: sodium dodecyl sulfate

SDS-PAGE: SDS-polyacrilamide gel electrophoresis

SEC: complejo de superelongación

SET: suppressor of variegation, enhancer of zeste, and trithorax

SIRT: sirtuinas

SSA: single strand annealing

SSBs: single-strand breaks

S/T-Q: Serina/Treonina-Glutamina

SWI/SNF: switch/sucrose-nonfermenting 


\section{T}

TBS-T: Tris buffer salinum - Tween-20

TCR: transcription-coupled repair

TEMED: N, N, N', N'-

tetrametiletilenodiamina

TSH2B: testis-specific histone $\mathrm{H} 2 \mathrm{~B}$ o H2B tipo 1 A

U

UV: radiación ultravioleta

u.a.: unidades arbitrarias

\section{V}

V: voltio

VEA: Valina-Glutámico-Alanina

VRK: Vaccinia-related kinase

\section{W}

WB: western blot

\section{$\mathbf{Z}$}

$\mathrm{Zn}^{2+}$ : ion zinc

\section{Otras abreviaturas}

53BP1: p53-binding protein 1

8-oxo-G: 7, 8-dihidro-8-oxoguanosina

$\mu \mathrm{g}:$ microgramo

$\mu \mathrm{l}$ : microlitro

$\mu \mathrm{m}$ : micrómetro

$\mu \mathrm{M}$ : micromolar

${ }^{\circ} \mathrm{C}$ : grado centígrado 


\begin{tabular}{|c|c|c|}
\hline \multicolumn{3}{|c|}{ Aminoácidos } \\
\hline \multicolumn{2}{|c|}{ Abreviatura } & Aminoácido \\
\hline A & Ala & Alanina \\
\hline C & Cys & Cisteína \\
\hline D & Asp & Aspártico \\
\hline E & Glu & Glutámico \\
\hline F & Phe & Fenilalanina \\
\hline G & Gly & Glicina \\
\hline H & His & Histidina \\
\hline I & Ile & Isoleucina \\
\hline K & Lys & Lisina \\
\hline L & Leu & Leucina \\
\hline M & Met & Metionina \\
\hline N & Asn & Asparagina \\
\hline T & Thr & Treonina \\
\hline V & Val & Valina \\
\hline W & Trp & Triptófano \\
\hline
\end{tabular}

\begin{tabular}{|c|c|}
\hline \multicolumn{2}{|c|}{ Bases Nitrogenadas } \\
\hline A & Adenina \\
\hline T & Timina \\
\hline G & Guanina \\
\hline C & Citosina \\
U & Uracilo \\
\hline
\end{tabular}

Tabla 1: Lista de aminoácidos y bases nitrogenadas con sus abreviaturas. 
Introducción 



\section{CROMATINA: ESTRUCTURA Y FUNCIÓN}

En las células eucariotas, la longitud del ADN genómico (de aproximadamente 4 metros en las células humanas) implica una organización estructurada del mismo que permita su empaquetamiento en el núcleo. Este ADN genómico se enrolla alrededor de las histonas y forma la cromatina. La primera imagen de las fibras de cromatina se obtuvo mediante microscopía electrónica y en ella se observaba una serie de partículas esféricas unidas mediante fragmentos de ADN (1). Posteriormente, estas partículas esféricas pasaron a llamarse nucleosomas y constituyen la unidad fundamental de la cromatina (2).

\subsection{Estructura de los nucleosomas}

Cada nucleosoma está formado por un octámero de histonas (nucleosome core), el ADN y la histona de unión (DNA and histone linkers), siendo una estructura altamente conservada desde las levaduras hasta los organismos eucariotas más evolucionados (3).

El octámero de histonas consta de dos copias de las histonas $\mathrm{H} 2 \mathrm{~A}, \mathrm{H} 2 \mathrm{~B}, \mathrm{H} 3$ y H4, en torno a las cuales se enrolla un segmento de ADN de 147 pares de bases (core DNA). La unión entre el $A D N$ y las histonas, mediada principalmente por la interacción entre los grupos fosfato del ADN y las cadenas laterales de lisinas y argininas de las histonas, impide que pueda ser digerido por las nucleasas (3). Además, esta unión restringe el acceso al ADN de los factores implicados en transcripción, replicación o reparación, por lo que, tanto las posiciones como la estructura de los nucleosomas, deben modificarse dinámicamente de manera espontánea o vía remodelación enzimática para garantizar el correcto funcionamiento de los distintos procesos celulares (4).

Las cuatro histonas que forman parte del nucleosoma son proteínas relativamente pequeñas (11-15 kDa) y de carácter básico. Todas ellas poseen un dominio central (histone-fold domain) altamente conservado que consta de tres hélices $\alpha$ ( $\alpha 1, \alpha 2$ y a3), conectadas por dos pequeños bucles ( $L 1$ y L2), y cuya función principal consiste en formar heterodímeros $\mathrm{H} 2 \mathrm{~A}-\mathrm{H} 2 \mathrm{~B}$ y $\mathrm{H} 3-\mathrm{H} 4$. Cada uno de los heterodímeros $\mathrm{H} 2 \mathrm{~A}$ $\mathrm{H} 2 \mathrm{~B}$ se incorpora de manera independiente al nucleosoma, mientras que los heterodímeros $\mathrm{H} 3-\mathrm{H} 4$ forman un tetrámero $(\mathrm{H} 4-\mathrm{H} 3: \mathrm{H} 3-\mathrm{H} 4)$. Este tetrámero se une a cada uno de los dímeros $\mathrm{H} 2 \mathrm{~A}-\mathrm{H} 2 \mathrm{~B}$ vía $\mathrm{H} 2 \mathrm{~B}: \mathrm{H} 4$ y da lugar a una cadena simétrica 
(H2A-H2B:H4-H3:H3-H4:H2B:H2A) que favorece la unión entre estas histonas y el $\operatorname{ADN}(3,4)$.
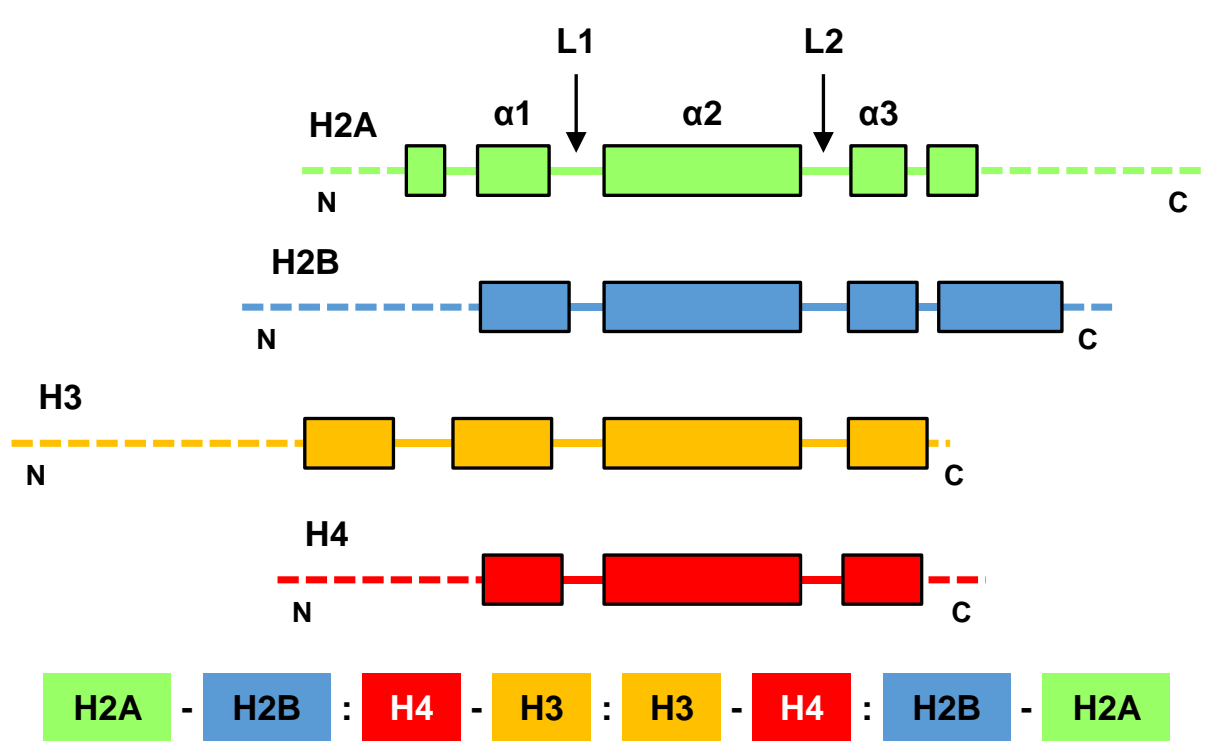

Figura 1: Estructura esquemática de las histonas canónicas que forman el nucleosoma. Adaptado de (3) y (4).

Los extremos $\mathrm{N}$-terminal de estas histonas y el $\mathrm{C}$-terminal de la histona $\mathrm{H} 2 \mathrm{~A}$ son colas flexibles, muy poco organizadas y ricas en lisinas y argininas. Estas regiones contienen sitios diana para multitud de enzimas implicadas en la modificación de histonas (writers), que generan puntos de unión para otras proteínas (readers) $(3,4)$. A su vez, las histonas H2A y H2B poseen regiones ricas en aminoácidos ácidos (acidic patch) en la superficie del nucleosoma que también sirven de anclaje para diversas proteínas (4).

La familia de histonas $\mathrm{H} 1$ (linker histones) también forma parte de la estructura del nucleosoma, pero sus miembros están menos conservados entre especies. Sus principales funciones son estabilizar el ADN enrollado en el nucleosoma, promover el plegamiento y ensamblaje de estructuras más compactadas de la cromatina, controlar el espaciado entre nucleosomas, regular la expresión génica y suprimir la transcripción de elementos repetitivos transponibles presentes en el ADN. Dichas funciones dependen, en muchas ocasiones, de modificaciones postraduccionales en estas histonas asociadas a procesos celulares como la replicación o la mitosis (3). 


\subsubsection{Variantes de histonas en el nucleosoma}

En mamíferos, además de las histonas canónicas (H2A, H2B, H3.1 (o H3.2) y H4), que se sintetizan durante la fase $S$ del ciclo (5), existen variantes de histonas que presentan homología de secuencia con las canónicas y que, por lo general, se sintetizan e incorporan al nucleosoma de manera independiente al ciclo celular. Estas variantes presentan diferentes características estructurales y funcionales, necesarias para la regulación de la cromatina (6).

En el genoma humano se han descrito multitud de genes que codifican variantes de histonas, sin tener en cuenta los correspondientes a las histonas canónicas. Existen 8 variantes de la histona H2A (H2A.X, H2A.Z.1, H2A.Z.2.1, H2A.Z.2.2, H2A.Bbd (H2A Barr body deficient o H2A.B), macroH2A1.1, macroH2A1.2 y macroH2A2) y 6 de la histona H3 (H3.3, CENP-A (histone H3-like centromeric protein A), H3.1T, H3.5, H3.X (también conocida como H3.Y.2) y H3.Y (denominada a su vez H3.Y.1)) en células somáticas. También se han identificado dos variantes de la histona H2B en los testículos (H2BFWT (histone H2B type WT o H2B.W) y TSH2B (testis-specific histone H2B o H2B tipo 1A). Sin embargo, no se han descubierto variantes de la histona H4 en organismos eucariotas superiores (6).

Estas variantes de histonas pueden influir directamente sobre la estructura nucleosomal. Este es el caso de la histona H2A.Bbd, cuya incorporación conduce a la formación de una cromatina menos compactada que facilita la transcripción (7), o de la variante H2A.Z.2.2, que contiene cambios estructurales en su extremo C-terminal que desestabilizan el nucleosoma (8).

En muchos casos, el efecto de estas histonas no canónicas depende de si el nucleosoma es homotípico (dos copias de la misma histona), heterotípico (una histona canónica y una variante) o posee dos variantes diferentes. Por ejemplo, los nucleosomas que contienen H2A.Z y H3.3 son menos estables y suelen localizarse en regiones reguladoras del genoma, como promotores activos o enhancers (9).

Además, la incorporación de variantes a la estructura de la cromatina tiene efectos indirectos sobre su organización y sobre otros procesos biológicos. Esto se debe a que las modificaciones postraduccionales asociadas a estas variantes no son las mismas que las de las histonas convencionales. Por esta razón, existen proteínas que reconocen específicamente a la histona $\mathrm{H} 2 \mathrm{AX}$ fosforilada en respuesta al daño génico (10) o a nucleosomas hiperacetilados en su histona $\mathrm{H} 4$ que contienen la variante H2A.Z.1 (11). 
En resumen, la incorporación de variantes de histonas es un proceso altamente regulado que modifica la organización de la cromatina alterando la estructura y estabilidad de los nucleosomas y/o promoviendo el reclutamiento de distintas proteínas responsables de sus funciones biológicas (12).

\subsection{Moduladores de la estructura de la cromatina}

La epigenética, que se define como los cambios en el fenotipo causados por mecanismos que no dependen de la secuencia de ADN, es esencial en el control de la expresión génica (13). Estos cambios epigéneticos se asocian a distintos procesos celulares e implican metilación del ADN, alteraciones en el posicionamiento de los nucleosomas y modificaciones covalentes de histonas, que, en su conjunto, modulan la estructura de la cromatina.

\subsubsection{Metilación del ADN}

La metilación del ADN consiste en la unión covalente de un grupo metilo $\left(-\mathrm{CH}_{3}\right)$ en la posición 5 de la citosina. Aquellas citosinas susceptibles a metilarse se localizan en dinucleótidos $\mathrm{CpG}$ y se acumulan en las denominadas islas $\mathrm{CpG}$, propias de regiones promotoras y/o del primer exón. Sin embargo, la expresión génica no depende de la densidad de islas $\mathrm{CpG}$ en sí mismas, sino de que estén metiladas o no. Las enzimas que catalizan esta reacción se denominan ADN metiltransferasas (DNMTs) y utilizan como donador del grupo metilo a la S-adenosil-metionina (SAM). La familia de las DNMTs consta de 5 miembros en mamíferos: DNMT1, DNMT2, DNMT3a, DNMT3b y DNMT3L, aunque parece que sólo DNMT1, DNMT3a y DNMT3b participan activamente en el patrón global de metilación de citosinas. De estas tres, DNMT3a y DNMT3b son metilasas de novo, asociadas a la embriogénesis y al desarrollo de las células germinales, mientras que DNMT1 es una metilasa de mantenimiento que se encarga de restaurar el patrón de metilación original en las nuevas cadenas de ADN sintetizadas durante la replicación (14).

\subsubsection{Posicionamiento de los nucleosomas: chaperonas de histonas y complejos remodeladores de cromatina dependientes de ATP}

La incorporación y eliminación de las histonas que forman parte del nucleosoma es un proceso altamente controlado tanto espacial como temporalmente y está mediado por chaperonas y complejos remodeladores de cromatina dependientes de ATP $(15,16)$. Las chaperonas participan en distintas etapas de la formación del nucleosoma y se unen directamente a las histonas recién sintetizadas para controlar su estabilidad y/o 
degradación. Algunas de ellas están implicadas en el tráfico de histonas entre el citoplasma y el núcleo, regulando las interacciones entre histonas e importinas; otras facilitan la unión a las histonas de las enzimas encargadas de modificarlas postraduccionalmente $\mathrm{y} / \mathrm{o}$ favorecen las interacciones entre histonas que permiten el ensamblaje de los nucleosomas (12). Desde el descubrimiento de la primera chaperona de histonas, la nucleoplasmina, se han identificado y caracterizado otras muchas asociadas a diferentes procesos celulares como la transcripción, la replicación y la reparación del $\operatorname{ADN}(12,16,17)$.

Junto con las chaperonas, los remodeladores de cromatina también participan activamente en el posicionamiento de las histonas, ya que son complejos multiproteicos capaces de alterar la estructura de la cromatina mediante la incorporación o eliminación de dichas histonas (12). Esto es posible gracias a la presencia de una subunidad ATPasa de la subfamilia Snf2 (dos plegamientos en tándem tipo RecA, DExx y HELICc) en dichos complejos, que permite reestructurar los nucleosomas utilizando la energía de la hidrólisis del ATP. Estos remodeladores de cromatina son muy abundantes en la célula, y se clasifican en cuatro familias: SWI/SNF (switch/sucrose-non-fermenting), ISWI (imitation switch), CHD (chromodomain-helicase-DNA binding) e INO80 (inositol requiring 80 ) $(18,19)$.

La familia SWI/SNF se caracteriza por presentar un dominio HSA (helicase-SANT) en su extremo N-terminal, implicado en el reclutamiento de actina o proteínas relacionadas con ella (ARPs, actin-related proteins), y un bromodominio (BRD) en su región carboxilo, que reconoce lisinas acetiladas en los extremos $\mathrm{N}$-terminales de las histonas (20). En humanos, existen dos tipos de SWI/SNF que constan de ocho o más proteínas y que se constituyen en torno a Brg1 y Brm. Los factores asociados a cada uno de estos tipos, denominados BAF (BRG1-associated factors) y PBAF (polybromoassociated $\boldsymbol{B A F}$, regulan las funciones de esta familia de remodeladores de cromatina, su ensamblaje y sus dianas $(18,19)$.

Los complejos ISWI son más pequeños que los SWI/SNF (de dos a cuatro subunidades, entre las que se encuentran las ATPasas SNF2H o SNF2L) y se caracterizan por la presencia de los dominios HAND, SANT y SLIDE en su región Cterminal con capacidad de unión al ADN y a las colas de las histonas (21). Las funciones de estos remodeladores están principalmente asociadas al espaciado de los nucleosomas, la respuesta al daño en el ADN y la represión transcripcional $(18,19)$. 


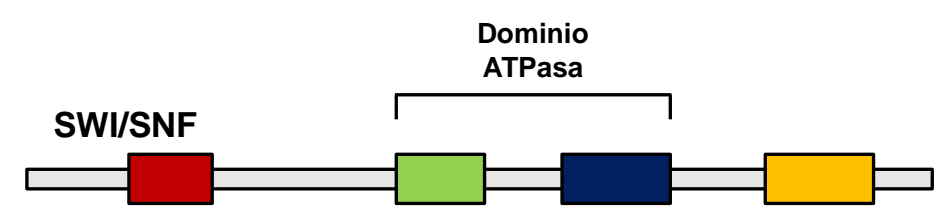

\section{ISWI}

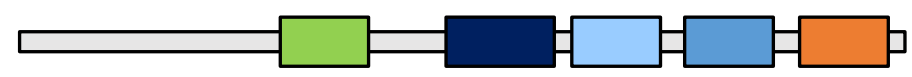

\section{CHD}

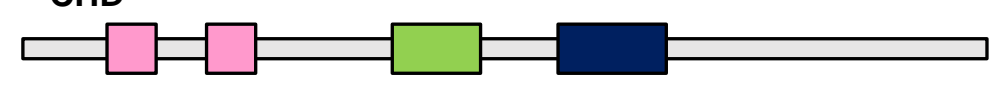

INO80

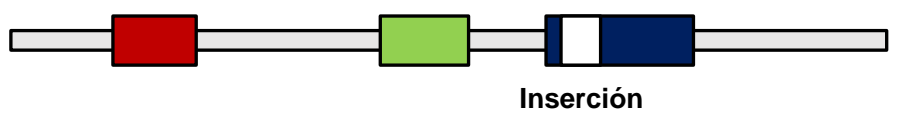

$\begin{array}{llll}\square & \text { Dominio HSA } & \square & \text { Dominio HAND } \\ \square & \text { DEXx } & \square & \text { Dominio SANT } \\ \square & \text { HELICC } & \square & \text { Dominio SLIDE } \\ \square & \text { Bromodominio } & \square & \text { Cromodominios }\end{array}$

Figura 2: Familias de complejos remodeladores de cromatina dependientes de ATP. Se indican los principales dominios que caracterizan a cada una de estas familias. Adaptado de (18) y (19).

La tercera de las familias, CHD, tiene como principal característica la presencia de dos cromodominios (CHD) en tándem en el extremo $\mathrm{N}$-terminal, responsables de la unión de estos remodeladores a las lisinas metiladas (21). Sin embargo, se han descrito tres subfamilias que se diferencian entre sí por sus motivos estructurales adicionales. La primera de estas subfamilias, formada por CHD1 y CHD2, tiene un dominio de unión al ADN que reconoce principalmente zonas ricas en pares AT en su región C-terminal. La siguiente subfamilia, compuesta por CHD3 (Mi-2 $\alpha$ ) y CHD4 (Mi$2 \beta$ ), carece de este dominio de unión al ADN, pero contiene dos motivos PHD tipo dedos de zinc en su extremo $\mathrm{N}$-terminal. Por último, la tercera subfamilia, que incluye a los miembros CHD6-9, posee dominios SANT en su región C-terminal. Cabe destacar que uno de los miembros de esta familia, CHD5, no se engloba en ninguna de estas subfamilias al contener dominios PHD y SANT en sus extremos $\mathrm{N}$ - y Cterminales, respectivamente (19).

Finalmente, la familia de remodeladores INO80 se caracteriza por la presencia de una larga inserción en su dominio ATPasa, al que se unen helicasas del tipo RuVB y 
proteínas relacionadas con la actina. De hecho, las subunidades motoras de estos complejos también poseen en su región $\mathrm{N}$-terminal un dominio HSA $(18,19,21)$.

\subsubsection{Modificaciones covalentes de histonas}

Como ya se ha mencionado en apartados anteriores, las histonas poseen extremos $\mathrm{N}$ terminales desestructurados que pueden ser modificados postraduccionalmente en función del proceso biológico en el que participen. Estas modificaciones covalentes alteran el patrón de interacción entre los nucleosomas o actúan como puntos de anclaje de proteínas no histonas, lo que conduce, por un lado, a la formación de distintas regiones en la cromatina (eucromatina y heterocromatina), y, por otro, a la regulación de procesos biológicos como la replicación, la transcripción o la reparación del ADN (22).

Una de las modificaciones covalentes mejor caracterizadas es la acetilación, catalizada por las acetiltransferasas de histonas (HATs). Estas enzimas transfieren el grupo acetilo procedente del acetil-coenzima A (acetil-CoA) al grupo amino $\varepsilon$ de algunas de las lisinas de las colas de las histonas y se clasifican en tres grandes familias: GNAT (GCN5-related $\mathbf{N}$-acety/transferase), MYST (por sus miembros MOZ, Ybf2/Sas3, Sas2 y Tip60) y CBP/p300, también conocida como EP300 (E1Aassociated protein p300) (23). Muchas de estas HATs forman parte de complejos multiproteicos y son los demás componentes de estos complejos los que determinan su actividad catalítica y especificidad (24).

La acetilación de histonas es un proceso reversible mediado por las deacetilasas (HDACs), las cuales catalizan la eliminación de los grupos acetilo de las lisinas (23). En humanos, se clasifican en 4 clases: I, II, III y IV. Las enzimas que pertenecen a las clases I (HDAC1-3 y -8), II (HDAC4-7, -9 y -10) y IV (HDAC11) pertenecen a la superfamilia de las arginasa/deacetilasas y utilizan como cofactor el zinc $\left(\mathrm{Zn}^{2+}\right)$. Sin embargo, la clase III (sirtuinas, SIRT1-7) cataliza una reacción particular en la que transforman la acetil-lisina y el $\mathrm{NAD}^{+}$(nicotinamide adenine dinucleotide) en lisina deacetilada, nicotinamida y 2'-O-acetil-ADP ribosa. De todos sus miembros, sólo las sirtuinas 1-3 tienen actividad deacetilasa y únicamente SIRT1 se localiza en el núcleo. La actividad de estas cuatro familias de HDACs depende de interacciones proteína-proteína y modificaciones postraduccionales, y puede estar regulada a través de su expresión, del procesamiento alternativo de su ARNm o de su localización subcelular (24). 
Otra de las modificaciones más prevalentes es la metilación, que afecta a residuos de lisina y arginina. Las metiltransferasas de histonas, conocidas también como PKMTs (protein lysine methyltransferases) o PRMTs (protein arginine methyltransferases) por su capacidad para metilar sustratos que no son histonas, catalizan la transferencia del grupo metilo procedente de la S-adenosil-L-metionina (SAM) a las lisinas (mono-, di- o trimetiladas) o argininas (mono- o dimetiladas de manera simétrica o asimétrica) localizadas en el extremo $\mathrm{N}$-terminal de las histonas, liberando S-adenosil-Lhomocisteina como producto de la reacción $(25,26)$. En el caso de las PKMTs, todas ellas, a excepción de DOT1L, presentan un dominio SET (suppressor of variegation, enhancer of zeste, and trithorax) encargado de mediar la metilación de los grupo amino $\varepsilon$ de las lisinas. Dentro de estas PKMTs, algunas sólo monometilan lisinas, como SET7/9, mientras que otras son capaces de mediar la mono-, di- y trimetilación de estas lisinas, como es el caso de G9a y EZH2. Por su parte, las PRMTs metilan el grupo guanidino terminal de las cadenas laterales de las argininas generando tres productos: monometilarginina, dimetilarginina asimétrica o dimetilarginina simétrica. PRMT7 sólo cataliza la monometilación, mientras que todas las demás también catalizan la monometilación y se clasifican en tipo I, si, a su vez, median la dimetilación asimétrica (PRMT1-4, -6 y -8), o tipo II, si la reacción es simétrica (PRMT5) (24).

Al principio se pensaba que la metilación de histonas era una modificación covalente estable y que sólo mecanismos no enzimáticos podían mediar la demetilación, pero los cambios en los niveles de metilación asociados al ciclo celular y a otros procesos biológicos pusieron de manifiesto la existencia de demetilasas de histonas (HDMs) (25). Estas HDMs, descritas únicamente para los residuos de lisina, se dividen en dos grupos en función del tipo de reacción enzimática que catalizan: las demetilasas lisina-específicas o LSD, y las de la familia Jumonji C (JMJC). Las enzimas LSD1/2 son amino-oxidasas dependientes de FAD (flavin adenine dinucleotide) que demetilan la $\mathrm{H} 3 \mathrm{~K} 4$ mono- y dimetilada generando $\mathrm{FADH}_{2}, \mathrm{H}_{2} \mathrm{O}_{2}$ y una imina, que se reduce y da lugar a la lisina demetilada y formaldehído en presencia de agua. La otra familia de demetilasas (JMJC) utiliza como cofactores de la reacción de oxidación/reducción al a-cetoglutarato y al hierro $\left(\mathrm{Fe}^{2+}\right)$, obteniendo como productos lisina demetilada, succinato y paraformaldehído. Esta reacción, catalizada por las JMJC, permite demetilar histonas que contienen lisinas mono-, di- o trimetiladas (24).

Junto con la acetilación y la metilación, la fosforilación y ubiquitinación de histonas son modificaciones esenciales en distintos procesos biológicos. Las proteínas quinasa, agrupadas en familias dentro del quinoma humano, son las encargadas de catalizar la 
transferencia del grupo fosfato $y$ del ATP a residuos de serina, treonina o tirosina, $y$ son las serina/treonina- o las tirosina-fosfatasas las que revierten esta unión covalente (27). Tanto la fosforilación como la defosforilación de histonas juegan un papel clave en la reparación del ADN, la regulación transcripcional y la compactación de la cromatina (24). La ubiquitinación de histonas, por su parte, es un proceso más complejo que el de la fosforilación y consiste en la unión reversible de una o más ubiquitinas a las lisinas correspondientes de las proteínas diana. El sistema de ubiquitinación está formado por 3 enzimas, de activación o E1, de conjugación o E2, y de ligación o E3, que median la formación de un enlace amida entre la glicina de la región C-terminal de la ubiquitina y la lisina de la proteína. Esto genera una proteína monoubiquitinada, pero el proceso puede repetirse secuencialmente para formar cadenas (28). La mono- o poliubiquitinación, en el caso de las histonas, está asociada a la aparición de marcas en la cromatina y de nuevos puntos de anclaje para otras proteínas en procesos celulares como la reparación del ADN o la regulación de la transcripción (29-32).

Dicho esto, se han descrito otras muchas modificaciones covalentes que también modulan la estructura de la cromatina y regulan la expresión génica, como son la sumoilación, propionilación, butirilación, crotonilación, 2-hidroxiisobutirilación, malonilación, succinilación y formilación de lisinas, la ADP ribosilación de lisinas y glutámicos, la deiminación y citrunilación de argininas, la isomerización de prolinas, la hidroxilación de tirosinas o la O-glucosil-N-acetilación de serinas y treoninas $(22,33)$.

\subsection{Cambios en la cromatina asociados a procesos celulares}

Durante la replicación, transcripción o reparación del $A D N$, la maquinaria celular necesita acceder al ADN que se encuentra empaquetado en fibras de cromatina en el núcleo. Esto exige una estricta regulación espacio-temporal de multitud de factores que permita modular la estructura de la cromatina en función de las necesidades celulares y sea capaz de devolverla posteriormente a su estado basal (34).

\subsubsection{Modificación de la cromatina en replicación}

Durante la replicación tiene lugar la duplicación del genoma, un proceso altamente regulado que garantiza la transmisión de la información genética a las células hijas. A su vez, esta duplicación del ADN tiene que ir acompañada de la duplicación de la cromatina en su conjunto para que el código epigenético también se transmita a la descendencia (34). 
El inicio de la replicación se puede dividir en tres etapas: el reconocimiento de los orígenes de replicación por los ORCs (origin recognition complexes) cuando las células salen de mitosis, el reclutamiento del complejo MCM (minichromosome maintenance), necesario para formar el pre-RC (pre-replication complex), durante G1 y el inicio de la replicación en sí mismo mediado por las quinasas DDK y las CDKs (quinasas dependientes de ciclinas) al comienzo de la fase $S$ (35).

Una vez iniciada, la replicación del ADN depende del replisoma, un complejo que necesita que se produzcan cambios en la estructura de la cromatina para funcionar correctamente. Estos cambios implican el desensamblaje de los nucleosomas que se encuentran delante de la maquinaria replicativa, el reciclaje de las histonas parentales en las cadenas de ADN recién sintetizadas, la síntesis de nuevas histonas en los sitios de replicación, el ensamblaje de las histonas nuevas y de las parentales para mantener la densidad de nucleosomas en las dos cadenas de ADN sintetizadas y la restauración de las marcas en las histonas y el ADN con el objetivo de devolver la cromatina a su estado original (36). Todos estos procesos están mediados por distintos modificadores de la estructura de la cromatina, que, en muchos casos, interaccionan con los componentes del replisoma y con otros factores no cromatínicos. Algunos de los más importantes aparecen reflejados en la tabla 2 (22, 25, 34-39):

\begin{tabular}{|c|c|}
\hline $\begin{array}{c}\text { Moduladores de cromatina } \\
\text { HBO1, conocida también como KAT7 } \\
\text { (HAT) }\end{array}$ & $\begin{array}{c}\text { Función } \\
\text { Inicio de replicación y acetilación de } \\
\text { histonas (H4K5, 8 y 12) }\end{array}$ \\
\hline FACT (Ch.) & $\begin{array}{c}\text { Inicio de replicación y ensamblaje / } \\
\text { desensamblaje de histonas }\end{array}$ \\
\hline ASF1 y NASP (Ch) & $\begin{array}{c}\text { Progresión de la horquilla de replicación } \\
\text { y ensamblaje / desensamblaje de } \\
\text { histonas }\end{array}$ \\
\hline Complejo RBAP46 (Ch.) - HAT1 (HAT) & $\begin{array}{c}\text { Acetilación de nuevas histonas (H4K5ac } \\
\text { y H4K12ac) }\end{array}$ \\
\hline ISWI e INO80 (RC) & $\begin{array}{c}\text { Progresión de la horquilla de replicación } \\
\text { en presencia de FACT }\end{array}$ \\
\hline p300 (HAT) & $\begin{array}{c}\text { Progresión de la horquilla de replicación, } \\
\text { acetilación de histona H3 y } \\
\text { procesamiento de los fragmentos de } \\
\text { Okazaki (Ch) }\end{array}$ \\
\hline EAflaje de la cromatina \\
\hline
\end{tabular}




\begin{tabular}{|c|c|}
\hline Moduladores de cromatina & Función \\
\hline HDAC1/2 (HDACs) & $\begin{array}{l}\text { Deacetilación de histonas para restaurar } \\
\text { el estado basal de la cromatina }\end{array}$ \\
\hline DNMT1 (DNMT) & Mantenimiento del ADN metilado \\
\hline $\begin{array}{c}\text { SMARCAD1 (RC) y SETDB1 (KMT1E) } \\
\text { (PKMT) }\end{array}$ & Mantenimiento de la heterocromatina \\
\hline WSTF-SNF2 (RC) & $\begin{array}{l}\text { Prevenir la formación injustificada de } \\
\text { heterocromatina }\end{array}$ \\
\hline $\begin{array}{l}\text { SET8, denominada también KMT5A } \\
\text { (PKMT) }\end{array}$ & $\begin{array}{l}\text { Reclutamiento de los ORCs a través de } \\
\qquad \text { la H4K20me1 }\end{array}$ \\
\hline ATRX5/6 (RC) & $\begin{array}{l}\text { Prevenir la re-replicación de dominios de } \\
\text { heterocromatina }\end{array}$ \\
\hline G9a (PKMT) & Silenciamiento génico (H3K9me1) \\
\hline ESCO1/2 (HAT) & Cohesión de las cromátidas hermanas \\
\hline
\end{tabular}

Tabla 2: Moduladores de la estructura de la cromatina implicados en replicación. HAT: acetiltransferasa; Ch: chaperona de histonas; RC: remodeladores de cromatina; HDAC: deacetilasa de histonas; DNMT: metiltransferasa del ADN; PKMT: lisina-metiltransferasa de histonas.

\subsubsection{Modulación de la estructura de la cromatina durante la transcripción}

La regulación de la expresión génica en la eucromatina es un proceso coordinado que implica el reclutamiento de moduladores de cromatina y factores de transcripción, que, en función del estímulo celular, promueven la activación transcripcional o el silenciamiento génico (22).

La transcripción mediada por la ARN polimerasa II (ARN pol II) transcurre siguiendo una serie de etapas ordenadas (iniciación, elongación y terminación) que se conocen como ciclo de transcripción. Este proceso depende del reclutamiento de factores de transcripción que se unen a regiones específicas del ADN y reclutan, a su vez, correguladores que activan o reprimen la transcripción. Además, otras proteínas, ARNs no codificantes y elementos de regulación en cis juegan un importante papel en el control de la transcripción y pueden interaccionar con los factores de transcripción o la ARN pol II en los promotores o las regiones génicas, de manera local, o en zonas más alejadas del genoma (enhancers) (40). 
La formación del complejo de pre-iniciación (PIC) y el reclutamiento de los factores de transcripción y de la ARN pol II a los promotores son los primeros eventos que tienen que ocurrir al inicio de la transcripción. Las modificaciones de histonas tienen un papel esencial a la hora de definir los promotores transcripcionalmente activos, siendo la trimetilación de la histona $\mathrm{H} 3$ en la lisina 4 la mejor caracterizada (H3K4me3). Esta modificación depende de gran variedad de metiltransferasas, entre las que se encuentran las MLL (mixed lineage leukemia) y los complejos SETD1A/B (SET domain containing $1 A$ and $B$ ). Dicha trimetilación participa en el reclutamiento del complejo TFIID, esencial para el reconocimiento del promotor y la formación del PIC, y de los complejos de acetiltransferasas SAGA y/o ATAC $(34,40)$. Concretamente, el reclutamiento de SAGA (Spt-Ada-GCN5 acetyltransferase), que tiene actividad acetilasa (GCN5/PCAF) y deubiquitinasa (USP22), media la acetilación de la histona H3 en la lisina 9 (H3K9ac) (41). Además, la fosforilación de la serina 10 de la histona H3 (H3S10ph) también promueve el reclutamiento de GCN5 $(25,42)$.

Otras modificaciones necesarias durante las primeras etapas de la transcripción son las fosforilaciones, acetilaciones y metilaciones de lisinas y argininas que afectan a la histona $\mathrm{H} 4(25,34,41,42)$. Algunas de estas modificaciones, junto con las de la histona $\mathrm{H} 3$, participan en el reclutamiento de complejos remodeladores de cromatina, como es el caso del SWI/SNF, capaz de unirse a las histonas acetiladas a través de sus bromodominios, y el ISWI, que depende de la H3K4me3 (34). También cabe destacar el papel de la ubiquitinación de la histona H2B (H2BK120ub) en estas primeras etapas, dado que, en un primer momento, media el reclutamiento del complejo SAGA $(22,29,34)$, pero que, posteriormente, tiene que deubiquitinarse vía USP22 para que se inicie la transcripción.

Todas las modificaciones mencionadas hasta ahora se localizan en la región promotora del gen que se va a transcribir, pero también es importante tener en cuenta las que afectan a regiones reguladoras como los enhancers. En estas zonas predomina la monometilación de la histona H4 en su lisina 20 (H4K20me1) y la acetilación de la lisina 27 de la histona H3 (H3K27ac). Esta última, a su vez, puede aparecer en las regiones promotoras (40).

El inicio de la elongación viene determinado por el reclutamiento del complejo de superelongación (SEC), dependiente de la H3K9ac (41) y de la fosforilación de la ARN Pol II $(34,40)$. Para su correcta progresión, es necesario que la histona 3 se metile en las lisinas 36 y 79. La trimetilación de la lisina 36 (H3K36me3), mediada por SETD2 $(22,40,43)$, parece ser clave en el reclutamiento del complejo FACT, que desplaza a los dímeros H2A-H2B durante esta fase de la transcripción $(34,40)$. Por su parte, la 
di- y trimetilación de la lisina 79 (H3K27me2/3) también son importantes para la activación transcripcional. Estas modificaciones están mediadas por DOTL1 y se localizan principalmente en regiones intergénicas, pero con un patrón distinto al de la H3K36me3 $(34,40)$.

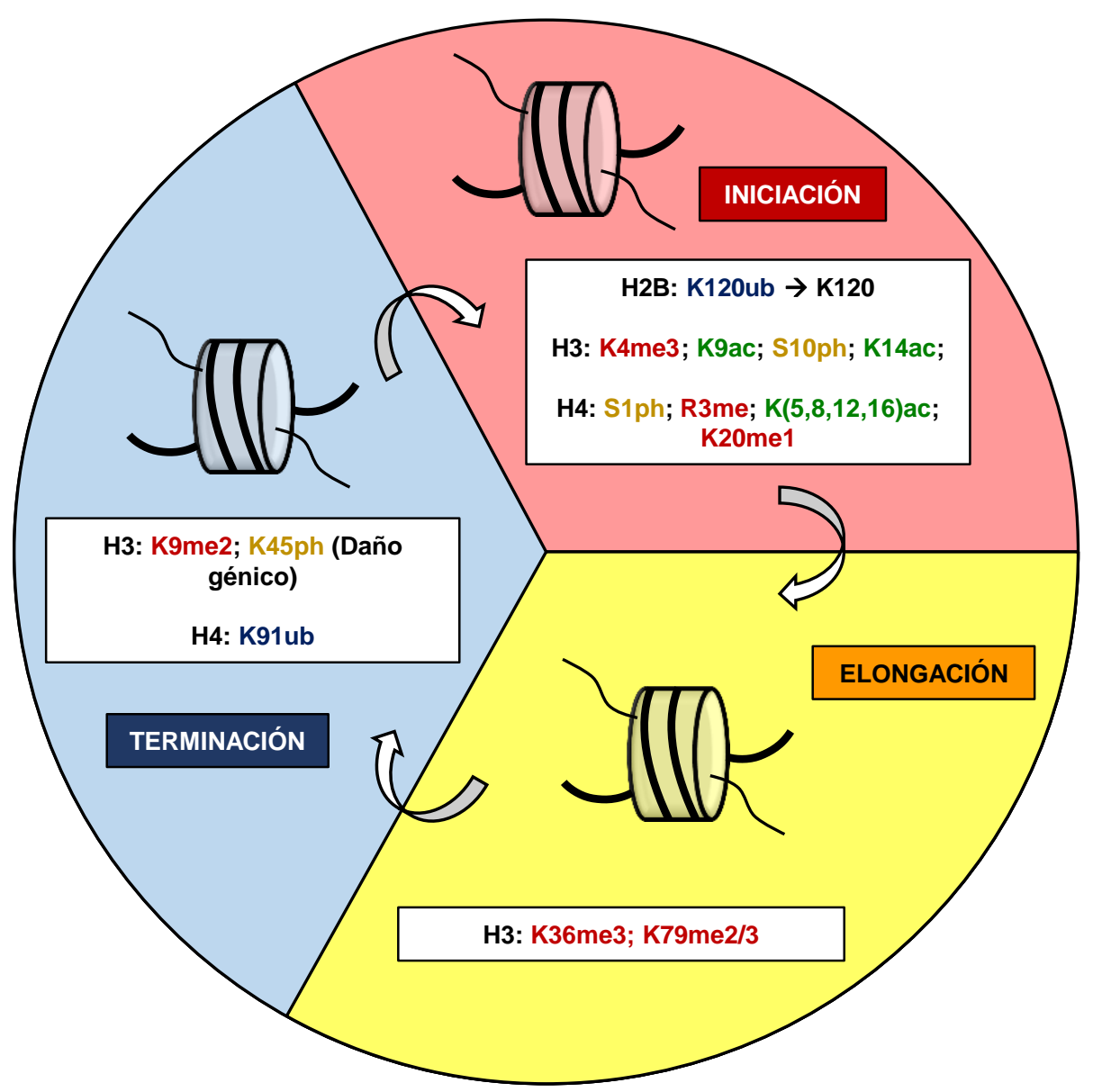

Figura 3: Esquema que ilustra las principales modificaciones en las histonas que componen el nucleosoma durante las distintas etapas de la transcripción. ub: ubiquitinación; me: metilación; ac: acetilación; ph: fosforilación. Adaptado de (40).

Finalmente, el proceso de terminación implica la poliadenilación del ARN mensajero (ARNm), su liberación de la ARN pol II y la separación de esta enzima del ADN molde. Desde el punto de vista de las modificaciones de histonas implicadas, no existe mucha información al respecto. Ahora bien, se ha descrito que la ubiquitinación de la lisina 91 de la histona $\mathrm{H} 4$ genera una cromatina más accesible para los factores de terminación (29) y que la dimetilación de la histona H3 en la lisina 9 (H3K9me2) cerca de los extremos 3' de los genes es una marca definitoria de final de transcripción (44). 
Además, se ha visto que la fosforilación de la treonina 45 de la histona H3 (H3K45ph) en respuesta al daño en el ADN conlleva la terminación de la transcripción, dado que acelera la degradación de ARN en el extremo 5' situado tras la cola de poliadeninas y promueve la disociación de la ARN pol II de la cromatina (45). También es importante hablar de las deacetilasas de histonas durante la terminación, ya que juegan un papel esencial en la recuperación del estado basal no acetilado de la cromatina (34).

Aparte de las modificaciones asociadas a la activación transcripcional, también hay que destacar su importancia en el silenciamiento génico. En el caso de la represión transcripcional, hay una mayor densidad de nucleosomas y las marcas más características son las metilaciones de la histona $\mathrm{H} 3$ en sus lisinas 9 y 27 (H3K9me2/3 y H3K27me3), la trimetilación de la histona H4 en su lisina 20 (H4K20me3) y la ubiquitinación de la histona H2A en su lisina 119 (H2AK119ub) (22, 29, 40). A su vez, otras modificaciones en las histonas como la sumoilación, la deiminación o la isomerización de prolinas, así como la metilación del ADN, están relacionadas con el silenciamiento de la expresión génica $(14,22)$.

En su conjunto, activación y represión transcripcional son procesos altamente coordinados, de forma que los factores asociados a la transcripción regulan negativamente a los del silenciamiento y viceversa. Esto establece un patrón característico que controla de manera estricta la expresión génica (29, 34, 40, 46-48).

\subsubsection{Cambios en la cromatina asociados a la reparación del ADN}

El genoma se encuentra empaquetado en fibras de cromatina que actúan como una barrera fisiológica para todos aquellos procesos asociados al ADN, como la replicación, la transcripción o la respuesta al daño génico (49).

Existen distintas fuentes de daño en el ADN que distorsionan la estructura de la cromatina y alteran la integridad del material genético. En este contexto, es necesario que la cromatina se relaje localmente y permita el reclutamiento y la acumulación de distintos factores de respuesta al daño en la zona donde se ha producido la lesión, para que pueda ser reparada y se restaure la homeostasis celular (49-51). Tanto los tipos de daño como los mecanismos implicados en su reparación, en los que participan distintos moduladores de la estructura de la cromatina, se detallan de manera más amplia en el siguiente apartado de esta introducción. 


\section{DAÑO Y REPARACIÓN DEL ADN}

Las células eucariotas están continuamente expuestas a agentes endógenos y/o exógenos causantes de roturas en el ADN que atentan directamente contra su integridad genómica. Para contrarrestar los posibles efectos de estas lesiones, existen diversos mecanismos altamente coordinados que se engloban en lo que se conoce como respuesta al daño en el ADN o DDR (DNA damage response), capaces de detectar, señalizar y reparar convenientemente el daño génico (52).
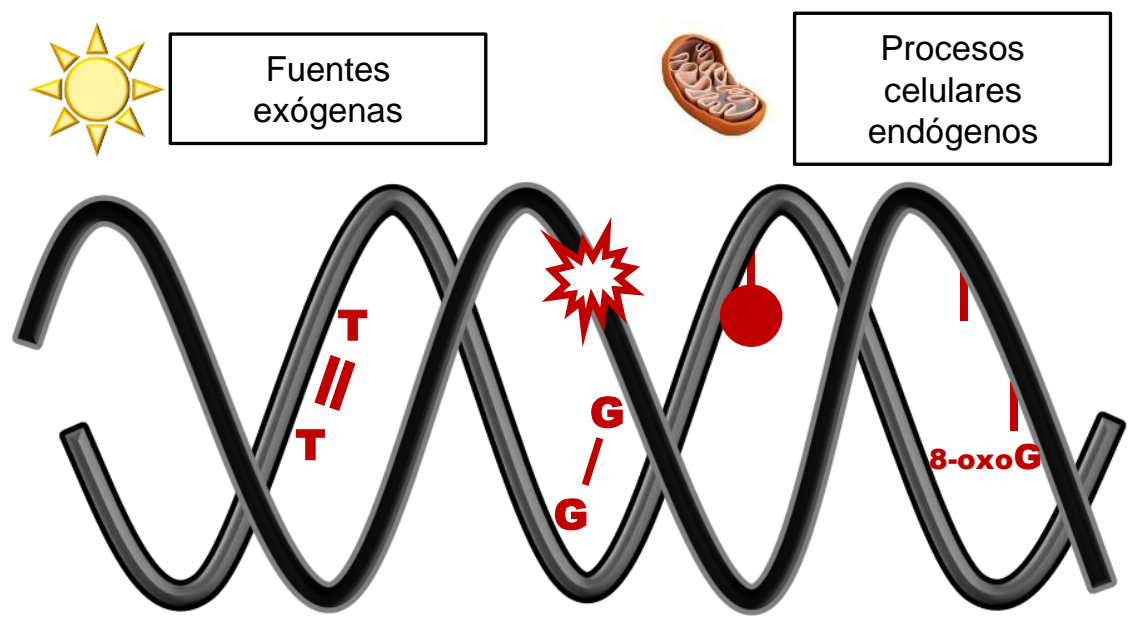

\section{Daño génico (SSBs y DSBs)}

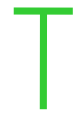

Cáncer y otras patologías

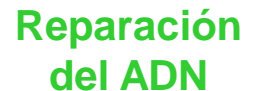

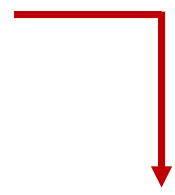

Envejecimiento

Figura 4: Los sistemas de reparación del ADN participan activamente en la prevención del envejecimiento y de patologías como el cáncer. Adaptado de (53).

La DDR se activa inmediatamente en respuesta a las lesiones en el ADN y debe, por una parte, inducir la parada del ciclo celular, con el fin de impedir que los defectos en el ADN se transmitan a las células hijas, y, por otra, iniciar la cascada de señalización adaptada a cada tipo de rotura que permita su reparación y restaure la integridad del material genético. En caso de que el daño génico se haya producido en células en división y se hayan reparado las roturas en el $A D N$, éstas vuelven a proliferar de 
forma normal. Sin embargo, en muchas ocasiones, las lesiones en el ADN son demasiado severas y no pueden repararse. Ante estas situaciones, las células activan un programa de muerte celular programada o una parada irreversible del ciclo celular, dependiendo del tipo celular y de la intensidad, duración y naturaleza del daño (54).

La acumulación de roturas en el ADN conlleva la aparición de mutaciones y aberraciones cromosómicas que, en última instancia, incrementan significativamente las posibilidades de sufrir cáncer y otras patologías relacionadas. Además, puede interferir en procesos celulares clave como la replicación o la transcripción, e inducir senescencia y apoptosis, directamente relacionadas con el envejecimiento (Figura 4). Por estas razones, la respuesta al daño en el ADN es esencial para el mantenimiento de la homeostasis celular (53).

\subsection{Agentes causantes de daño en el ADN}

Cada célula del organismo acumula multitud de lesiones en el ADN al día causadas por la propia actividad celular o por factores asociados al ambiente. Estas lesiones pueden afectar a una única hebra de ADN (SSBs, single-strand breaks) o a las dos (DSBs, double-strand breaks).

\subsubsection{Procesos celulares endógenos causantes de daño génico}

Una de las causas más corrientes de daño es la hidrólisis no enzimática del enlace glucosídico entre la desoxirribosa y la base nitrogenada, generando sitios AP (apurínicos o apirimidínicos) en el ADN que distorsionan su estructura (55).

También es frecuente la aparición de metilaciones atípicas en el ADN. La S-adenosilmetionina (SAM) es el donador de grupos metilo más habitual y se comporta como un agente alquilante débil. La lesión más abundante es la 7-metilguanosina, que se produce de manera espontánea y parece ser inocua, y la más citotóxica, la 3metiladenina. Otros agentes metilantes minoritarios también pueden inducir la aparición de 3-metiladenina y de otras modificaciones, como la $0^{6}$-metilguanina (55).

Otra alteración en el ADN asociada a procesos endógenos es la desaminación de bases como la citosina, adenina, guanina o 5-metilcitosina, que se transforman en uracilo, hipoxantina, xantina y timina, respectivamente. Si estos cambios no se reparan y dado que algunas de estas desaminaciones generan nucleótidos presentes de forma normal en el ADN, pueden generar mutaciones y transmitirse a la descendencia (56). 
Cabe destacar también el papel que juegan las especies reactivas de oxígeno (ROS, reactive oxygen species), derivadas de la respiración oxidativa y la peroxidación de los lípidos, en la generación de lesiones en el ADN. Estos productos procedentes del metabolismo celular actúan como fuertes oxidantes y reaccionan con las hebras de ADN generando roturas de cadena sencilla o de doble cadena. Entre las formas más deletéreas de daño causadas por ROS está la 7,8-dihidro-8-oxoguanosina (8-oxo-G), que se genera por oxidación de la guanina. Esta variante es capaz de interaccionar con nucleótidos de citosina y de adenina, lo que puede dar lugar a mutaciones de transversión GC-TA $(56,57)$.

Por último, estas lesiones en el ADN también pueden deberse a errores en la incorporación de nucleótidos durante la replicación o al funcionamiento defectuoso de enzimas como las ADN toposiomerasas I y II durante la transcripción, procesos celulares en los que es necesario que la estructura del $\operatorname{ADN}$ se relaje $(52,58)$.

\subsubsection{Agentes exógenos causantes de daño en el ADN}

Una de las mayores fuentes de daño exógeno en el ADN es la radiación ultravioleta (UV) asociada a la luz solar. La capa de ozono sólo es capaz de absorber la radiación UV más dañina, la luz UV-C, y son las otras partes del espectro ultravioleta (UV-A y UV-B) las que causan innumerables lesiones en el ADN (52). Este tipo de radiación genera dímeros de pirimidina (dentro de la misma cadena o en cadenas adyacentes) y otros fotoproductos que alteran la estructura normal de los ácidos nucleicos.

También las radiaciones ionizantes, como la radiación cósmica y aquellas que se emplean en tratamientos médicos con rayos $\mathrm{X}$ y radioterapia, son responsables de la aparición de roturas de cadena sencilla y doble cadena, ya que inducen la producción de altas cantidades de ROS que conducen a la oxidación del ADN (59).

Además de las radiaciones, la exposición a agentes químicos de distinta naturaleza genera lesiones en el ADN. Los miembros más representativos de este grupo son los agentes alquilantes como el metil-metanosulfonato (MMS), la metil-nitrosurea (MNU) o la temozolomida, entre otros, que unen grupos alquilo a las bases del $\operatorname{ADN}(59,60)$. Otros compuestos introducen enlaces covalentes ente las bases nitrogenadas de la misma cadena o con las de la cadena adyacente, como es el caso de la mitomicina $\mathrm{C}$ (MMC), el cisplatino, el psoraleno o las mostazas nitrogenadas. Finalmente, cabe destacar también que inhibidores de la ADN topoisomerasa (doxorrubicina, camptotecina y etopóxido) causan roturas de cadena sencilla y de doble cadena al unirse covalentemente a los complejos ADN-topoisomerasa (59). 


\subsection{Reparación de las roturas de cadena sencilla (SSBs)}

Para minimizar los efectos nocivos de las roturas de cadena sencilla en el ADN, existen mecanismos altamente conservados que se encargan de repararlas de manera específica en función de su origen.

\subsubsection{Reparación directa o in situ}

Este mecanismo se basa en la reparación inmediata de las lesiones en el ADN mediante la activación de enzimas concretas, capaces de eliminar los nucleótidos o las bases nitrogenadas equivocadas y mediar la síntesis correcta a continuación. Algunos ejemplos de este tipo de reparación son la activación de las enzimas 3metiladenina-ADN-glicosilasa y 0-6-metilguanina-ADN metiltransferasa, encargadas de eliminar el grupo metilo adicional de adeninas y guaninas, respectivamente (53, 55), o la fotorreactivación, que media la reparación de los dímeros de pirimidina generados tras la exposición a la radiación UV por acción de la fotoliasa $(61,62)$.

\subsubsection{Reparación por escisión de bases}

Este tipo de reparación, conocido por sus siglas en inglés BER (base excision repair), se activa principalmente en respuesta al daño génico producido por el metabolismo celular, incluyendo el asociado a las ROS y a la metilación, desaminación e hidroxilación de bases nitrogenadas. En este proceso, una ADN glicosilasa rompe el enlace entre la base dañada y el esqueleto de azúcar-fosfato del nucleótido en cuestión y genera un sitio AP, que también puede aparecer en el ADN por hidrólisis espontánea de la base. Llegados a este punto, la endonucleasa APE1 escinde el sitio AP y la polimerasa PARP y la quinasa PNK se activan y se unen a los extremos para protegerlos. Si la reparación sigue el camino corto (short patch), la ADN polimerasa $\beta$ incorpora el nucleótido correspondiente y elimina el azúcar-fosfato residual del extremo 5' mediante su actividad liasa, para que, finalmente, sea el complejo XRCC1ligasa 3 el que selle la unión. Por el contrario, si se activa el camino largo (long patch), las ADN polimerasas $\beta$ y $\delta / \varepsilon$, y la proteína PCNA (proliferating cell nuclear antigen) participan en la síntesis de una cadena de 2 a 10 nucleótidos que desplaza a la que ya estaba presente y que tiene que ser eliminada por la exonucleasa FEN1. Hecho esto, la ADN ligasa 1 es la encargada de sellar la unión (56). 


\subsubsection{Reparación por escisión de nucleótidos}

Este mecanismo, también denominado NER (nucleotide excision repair), es el más versátil para la reparación de SSBs, generalmente aductos en el ADN y dímeros de pirimidinas, y puede actuar a nivel de todo el genoma (GG-NER, global genome NER) o asociado a la transcripción (TCR, transcription-coupled repair).

El complejo XPC-hHR23B específico de GG-NER es el encargado de detectar los pares de bases afectados. Sin embargo, en el caso de la reparación mediada por TCR, es necesario, por una parte, conocer el tipo de lesión y, por otro, desplazar la ARN polimerasa para que dicha lesión se pueda reparar, proceso en el que participan los factores CSB y CSA. A partir de este punto, la reparación es idéntica en ambos casos. Las helicasas XPB y XPD, que forman parte del complejo TFIIH, generan una apertura de unos 30 pares de bases entorno a la zona donde se ha producido el daño y XPA se encarga de verificar la presencia de la lesión y de determinar cuál es la hebra afectada. Seguidamente, la proteína RPA (replication protein $\boldsymbol{A}$ ) se une al ADN y estabiliza el intermediario generado para que XPG y ERCC1/XPF corten la cadena dañada por sus extremos 3' y 5', respectivamente. Esto ocasiona la aparición de un hueco de entre 24 y 32 pares de bases que será rellenado posteriormente por las ADN polimerasas $\delta / \varepsilon y$, por último, son las ADN ligasas III y, en menor medida, la I en células replicativas, las que se encargan de sellar los extremos y restaurar el estado inicial de la doble hélice del ADN $(56,63)$.

\subsubsection{Reparación de apareamientos erróneos o mismatch repair (MMR)}

La maquinaria implicada en este mecanismo de reparación debe ser capaz de reconocer de manera eficiente los apareamientos erróneos o mistmatches, así como los loops de inserción/deleción generados durante el proceso replicativo, y promover la reparación en la nueva hebra de $\mathrm{ADN}$, que transporta la información genética errónea.

En mamíferos, los miembros de la familia MSH 2, 3 y 6 forman heterodímeros y se encargan de detectar estas lesiones en el ADN. El complejo MSH2/6 (MutSa) reconoce los apareamientos erróneos y los bucles de una o dos bases, mientras que el heterodímero MSH2/3 (MutS $\beta$ ) se une a los loops de inserción/deleción de mayor tamaño. A continuación, otros complejos heterodiméricos, MLH1/PMS2 (MutLa) y MLH1/PMS1 (MutL $\beta$ ), se unen a los heterodímeros mencionados anteriormente y a otros factores replicativos, y juegan un papel crucial a la hora de determinar la cadena que se está sintetizando y que, por tanto, debe repararse. Finalmente, un conjunto de 
proteínas entre las que destacan las ADN polimerasas $\delta / \varepsilon$, RPA, PCNA, RFC, la exonucleasa 1 y la endonucleasa FEN1, se encargan de escindir la cadena que contiene errores y de volver a sintetizarla de nuevo $(56,64)$.

\subsection{Reparación de las roturas de doble cadena (DSBs)}

En la mayoría de ocasiones, las roturas de doble cadena en el ADN, ya sean de origen endógeno o exógeno, atentan directamente contra la integridad genómica. Sin embargo, algunos procesos celulares conllevan alteraciones genéticas programadas basadas en este tipo de lesiones en el ADN. Este es el caso de las recombinaciones $\mathrm{V}(\mathrm{D}) \mathrm{J}$ y CSR (class-switch recombination), y la hipermutación somática. Estos procesos tienen lugar en los linfocitos $\mathrm{B}$ y $\mathrm{T}$ y son los responsables de generar diversidad de inmunoglobulinas y de receptores de células $\mathrm{T}$ ( $\boldsymbol{T}$-cell receptor), respectivamente, que permiten al organismo adaptarse y reconocer específicamente diversos antígenos y patógenos $(52,65)$. También existe intercambio de material genético mediado por roturas de doble cadena transitorias entre las cromátidas hermanas durante la meiosis, lo cual favorece la variabilidad genética vía reproducción sexual $(52,66)$.

Dicho esto, la reparación de las DSBs que no se producen de forma natural en la célula es esencial para el restablecimiento de la homeostasis celular, debido a la estrecha relación existente entre los defectos en el ADN y la esterilidad, el envejecimiento y patologías como el cáncer, las enfermedades neurodegenerativas y cardiovasculares, las deficiencias en el sistema inmunitario o el síndrome metabólico (52). Los principales mecanismos de reparación de este tipo de lesiones, las más deletéreas para el organismo, son la unión de extremos no homólogos (NHEJ, nonhomologous end joining), basada en la unión directa de los extremos generados tras la rotura, y la recombinación homóloga (HR, homologous recombination), que utiliza la cromátida hermana como molde para restaurar el estado inicial del material genético (67).

\subsection{Cambios en la estructura de la cromatina y dinámica de formación de focos de reparación en las DSBs}

El correcto funcionamiento de la respuesta a este tipo de daño en el ADN implica la coordinación de una gran cantidad de proteínas que operan en el contexto de una cromatina altamente organizada. En su conjunto, esta compleja maquinaria tiene que ser capaz de detectar de manera eficiente el tipo de daño en función de su origen, mediar el reclutamiento de otros factores implicados en la reparación, amplificar la 
señal y desencadenar la respuesta adecuada en cada caso, que va desde la parada del ciclo celular y la reparación en sí misma, hasta la activación de programas de senescencia o apoptosis si fuera necesario $(54,68)$.

\subsubsection{Reconocimiento del daño y activación de las proteínas sensoras}

La cromatina en sí misma constituye una barrera fisiológica para todos aquellos procesos celulares que implican el desdoblamiento de la doble hélice, como es el caso de la transcripción, la replicación o la reparación del ADN. En base a esta premisa, la detección del daño en el ADN y la activación de las proteínas sensoras deben ir acompañadas de modificaciones secuenciales en la estructura de la cromatina.

Uno de los cambios mejor caracterizados en respuesta a las roturas de doble cadena es la relajación local de la cromatina, asociada al aumento de la acetilación de las histonas $\mathrm{H} 2 \mathrm{~A}$ y $\mathrm{H} 4$. La acetilación de la histona $\mathrm{H} 4$, esencial en el inicio de la reparación, depende principalmente de las acetiltransferasas (HATs, histone acety/transferases) MOF y Tip60 (KAT5) (69-71). Esta última forma parte del complejo remodelador de cromatina NuA4, siendo uno de sus cuatro componentes con actividad catalítica, junto con la ATPasa p400 y las proteínas tipo helicasa Ruvbl1 y Ruvbl2, y tiene como sustratos, además de la histona $\mathrm{H} 4$, a la histona $\mathrm{H} 2 \mathrm{~A}$, la quinasa ATM (ataxia-telangiectasia mutated) y el factor de transcripción p53, entre otros. También la ATPasa p400 participa en la generación de una estructura más abierta de la cromatina en respuesta a las DSBs, ya que media el intercambio entre la histona $\mathrm{H} 2 \mathrm{~A}$ y su variante H2A.Z, dando lugar a nucleosomas menos estables. Es importante destacar que este evento precede y es imprescindible para la acetilación de la H4 mediada por Tip60 (Figura 5.A) (70). A su vez, la descondensación de la cromatina en respuesta al daño génico favorece la unión de Tip60 a dos marcas epigenéticas que quedan expuestas, las trimetilaciones de las lisinas 9 y 36 de la histona H3 (H3K9me3 y H3K36me3), asociadas a heterocromatina y eucromatina, respectivamente, lo que potencia su actividad acetiltransferasa $(72,73)$.

El papel de ATM es especialmente importante a la hora de detectar el daño e iniciar la cascada de señalización que media la reparación de estas roturas. En condiciones basales, se encuentra formando un dímero que es inactivo. Tras la inducción del daño génico, esta proteína pasa a formar monómeros activos (74), un proceso que depende de su acetilación en la lisina 3016 mediada por Tip60 (75) y su posterior autofosforilación en residuos de serina (367, 1893, 1981 y 2996) y treonina (1885) (76). Sin embargo, ATM no es completamente activa hasta que se recluta al lugar 
donde se ha producido la lesión, un proceso mediado por el complejo MRN (Mre11Rad50-NBS1) (76) y posterior a la relajación local de la cromatina (51) (Figura 5.A). También se ha descrito que la proteína de unión a nucleosomas HMGN1 modula la unión de ATM a la cromatina y promueve un aumento de la acetilación de la histona H3 en su lisina 14 en respuesta a IR (77). Además, estudios recientes demuestran que la acetilación de ATM mediada por Tip60 depende de la relajación de la cromatina y de la fosforilación de esta HAT. Esto se debe a que, en respuesta a radiación ionizante, c-Abl, una tirosina quinasa implicada en DDR, fosforila a Tip60 en la tirosina 44, y promueve su unión a la H3K9me3 expuesta tras la hiperacetilación de la cromatina inducida por el daño génico, favoreciendo así la posterior acetilación de ATM (78).

El complejo MRN está altamente conservado en la evolución y participa en la reparación de DSBs mediada por recombinación homóloga y unión de extremos no homólogos, así como en el mantenimiento de los telómeros y la regulación de los puntos de control del ciclo celular o checkpoints $(79,80)$. Está compuesto por las proteínas Mre11 (meiotic recombination 11), Rad50 y NBS1 (Nijmegen breakage syndrome 1, también conocida como nibrin o p95). Las proteínas Mre11, con actividad endo- y exonucleasa y de unión al ADN, y Rad50, que tiene actividad ATPasa, interaccionan y forman un heterotetrámero $\left(\mathrm{M}_{2} \mathrm{R}_{2}\right)$ con tres dominios (cabeza, espiral y gancho), que se unen a través del motivo $\mathrm{CxxC}$ de las dos unidades de Rad50, del mismo o de otros complejos, en presencia de zinc $\left(\mathrm{Zn}^{2+}\right)$ (81). NBS1, por su parte, carece de actividad catalítica, pero su fosforilación media el reclutamiento de otras proteínas implicadas en la reparación y su secuencia de localización nuclear y su interacción con Mre11 son las responsables de la translocación del complejo MRN al núcleo (80). En conjunto, el complejo MRN juega un papel esencial en el reconocimiento y unión de los extremos de ADN generados tras la rotura (82) y como punto de ensamblaje, bien entre distintas regiones de ADN dañadas, más o menos cercanas, o bien con otras proteínas asociadas a la respuesta al daño génico y a la activación de los puntos de control del ciclo celular (81).

En estos primeros compases de la respuesta, además de la acetilación de histonas, es importante que la histona $\mathrm{H} 2 \mathrm{AX}$, una variante de la histona $\mathrm{H} 2 \mathrm{~A}$ que constituye entre un 10 y un $15 \%$ en eucariotas superiores, se fosforile en su residuo de serina 139, pasando a denominarse $\operatorname{yH} 2 \mathrm{AX}(67,68)$. Esta fosforilación es posterior al reclutamiento del complejo MRN al sitio dañado (83) y, hasta hace relativamente poco tiempo, se pensaba que sólo estaba mediada por las quinasas de la familia PIKK (phosphoinositole 3-kinase-like kinases), que son ATM, ATR (ataxia-telangiectasia 
and rad3 related protein kinase) y DNA-PKcs (DNA-dependent protein kinase, catalytic subunit) (84). Sin embargo, estudios más recientes han demostrado que otras quinasas cromatínicas como VRK1 fosforilan también a la histona H2AX en el mismo residuo independientemente de ATM (Figura 5.A) (85).

Además de la histona H2AX, ATM fosforila a los tres miembros del complejo MRN. En el caso de NBS1, sus dianas de fosforilación son las serinas 278 y 343 (fosforilada también por VRK1 (86)) y en el de Rad50, la serina 635, ambas importantes para la activación del checkpoint de fase $S$, entre otras funciones. Por otra parte, ATM fosforila a Mre11 en las serinas 676, 678 y 681 y es esencial en la resección del ADN (87). A su vez, esta quinasa también fosforila a la acetiltransferasa MOF en la treonina 392, un paso clave para la supervivencia celular y la reparación del ADN en las fases $\mathrm{S} / \mathrm{G} 2$, poniendo en relieve el papel de MOF en los procesos anteriores y posteriores a la activación de ATM (71).

\subsubsection{Reclutamiento de las proteínas mediadoras: selección del mecanismo de reparación}

La histona $\mathrm{yH} 2 \mathrm{AX}$ promueve el reclutamiento y la acumulación de proteínas implicadas en DDR que forman focos de reparación en las regiones del ADN dañadas $(54,69)$. Una de las proteínas que reconoce directamente a $\mathrm{YH} 2 \mathrm{AX}$ es MDC1 (mediator of DNA damage checkpoint protein 1) (88) y esta interacción depende de la acetilación de la H4K16 mediada por MOF. Esta unión YH2AX-MDC1 conduce a la formación de un bucle de retroalimentación positivo, dado que conlleva un mayor reclutamiento de ATM activo y una mayor fosforilación de H2AX, lo que permite amplificar la respuesta (Figura 5.B) (69). Además, ATM fosforila a MDC1 en su treonina 4, una modificación covalente necesaria para que MDC1 dimerice y estabilice la unión del complejo MRN en la zona del ADN dañada mediante su interacción con NBS1 $(69,89)$.

La formación del complejo $\mathrm{yH} 2 \mathrm{AX}-\mathrm{MDC} 1$ depende también de la pérdida de otras modificaciones en la histona $\mathrm{H} 2 \mathrm{AX}$, como es el caso de la fosforilación de tirosina 142, ya que MDC1 sólo se une a $\mathrm{YH} 2 \mathrm{AX}$ si la Y142 está defosforilada. De hecho, la defosforilación del residuo 142, mediada por las fosfatasas EYA1 y 3, es importante para la activación de la DDR, dado que, en caso contrario, constituye un punto de unión para factores pro-apoptóticos (90). 

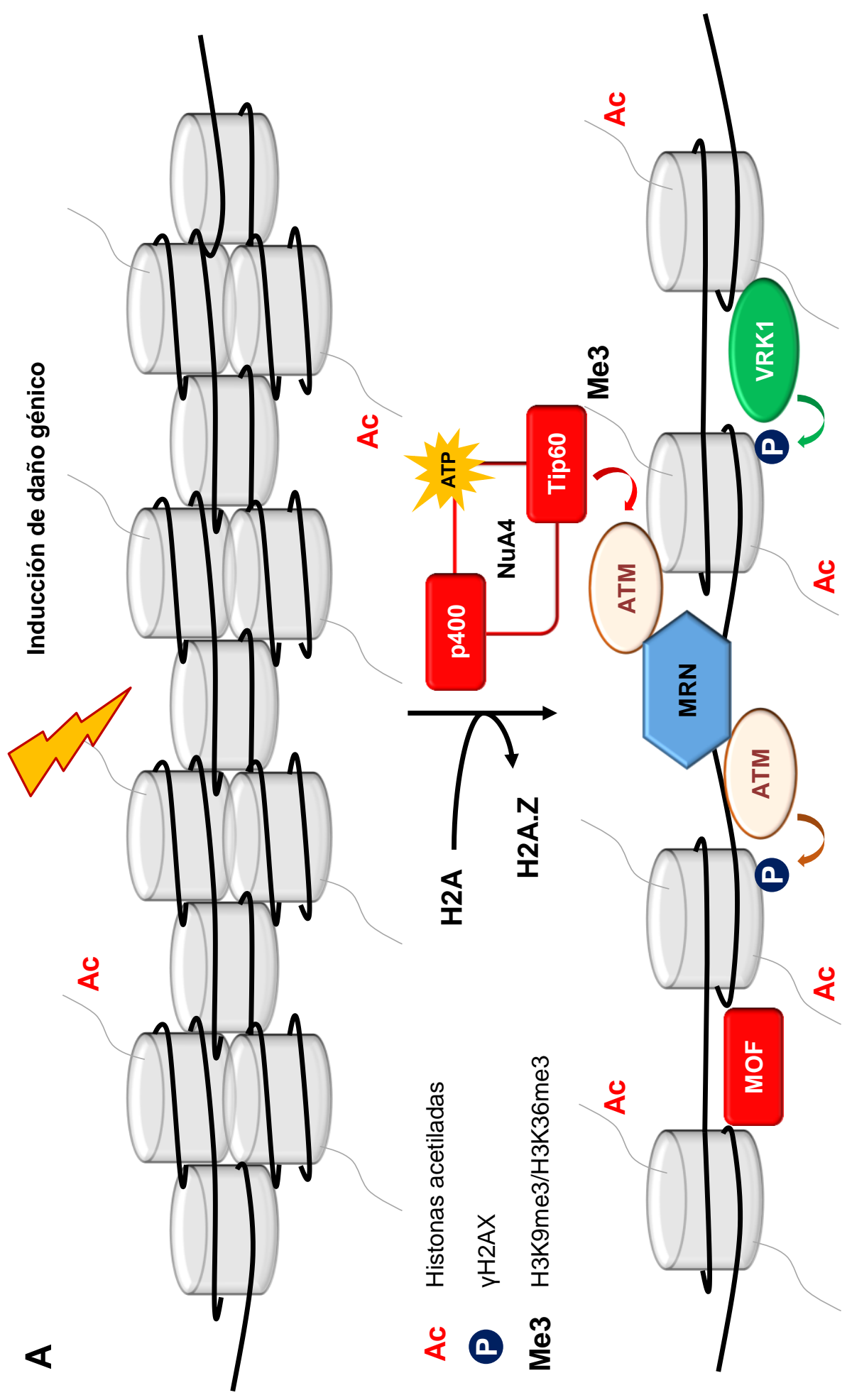


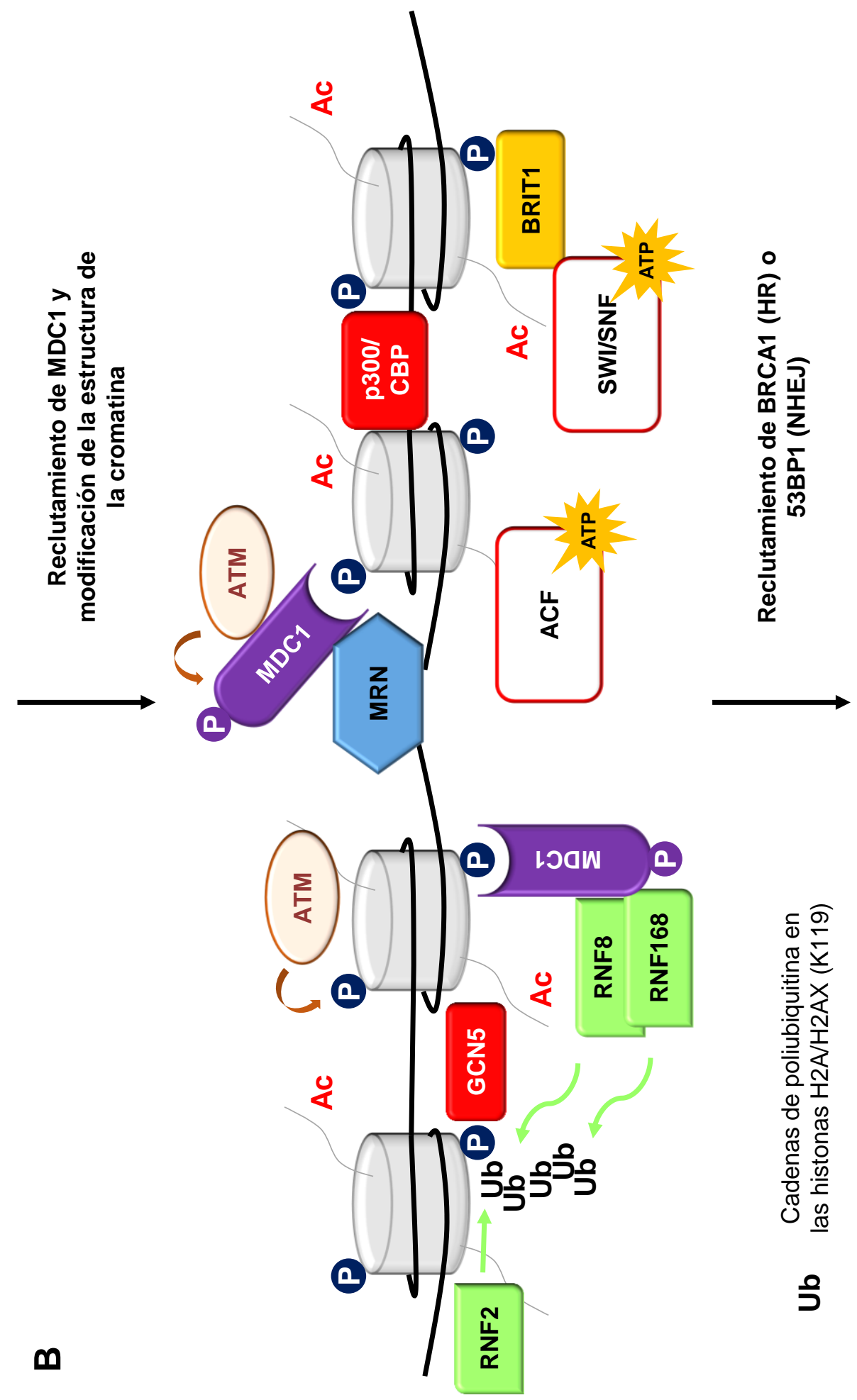




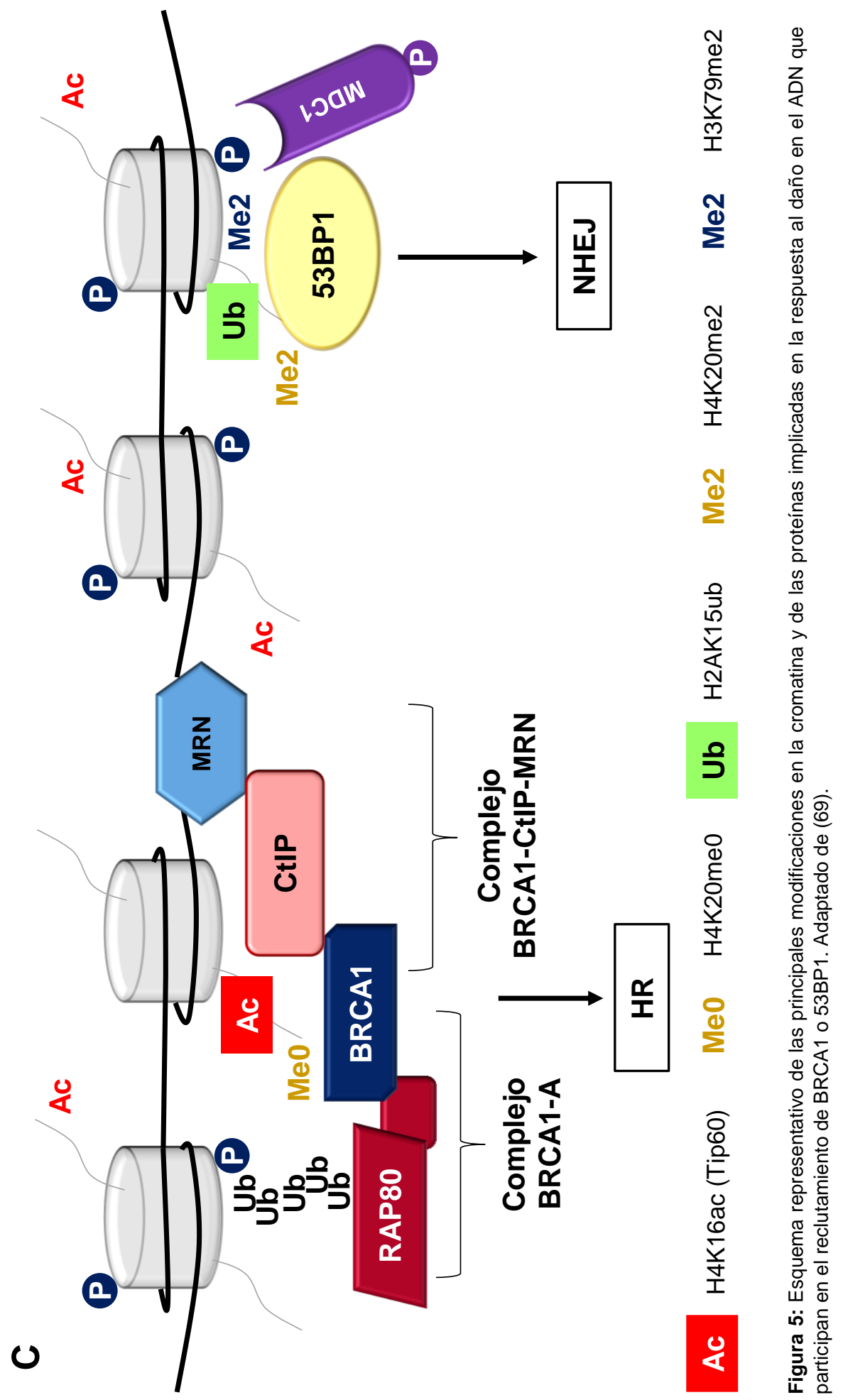


La acetilación de la histona $\mathrm{H} 3$ es otra de las modificaciones covalentes inducidas por el daño génico que depende de $\mathrm{yH} 2 \mathrm{AX}$. Esta acetilación es posible gracias a la unión de la acetiltransferasa GCN5 a los nucleosomas que contienen la histona H2AX fosforilada y sirve como punto de anclaje de complejos remodeladores de cromatina dependientes de ATP como el SWI/SNF. El reclutamiento de este complejo remodelador depende también de su interacción con la proteína BRIT1 (conocida también como MCPH1 o microcephalin 1), que se une a través de sus dominios BRCT a $\mathrm{YH} 2 \mathrm{AX}$. Una vez localizado en las zonas dañadas, SWI/SNF aumenta la accesibilidad de la cromatina y promueve aún más la fosforilación de H2AX asociada a ATM (Figura 5.B) $(10,69,91,92)$.

Otros complejos remodeladores de cromatina dependientes de ATP, como el ACF, se translocan a las DSBs de manera independiente a $\mathrm{YH} 2 \mathrm{AX}$. Este complejo consta de dos proteínas, la ATPasa SNF2H y la subunidad no catalítica ACF1, responsable del reclutamiento de SNF2H a la zona donde se ha producido la lesión (93).

Al igual que GCN5, otras HATs de las histonas H3 y H4, como p300 y CBP, se acumulan en las zonas dañadas y cooperan con algunas de las subunidades del complejo SWI/SNF (BRM y BRG1) en la relajación de la cromatina y el reclutamiento de otros factores necesarios para el proceso de reparación (69).

Junto con la acetilación, la ubiquitinación de histonas también es esencial en el reclutamiento de mediadores de la respuesta al daño en el ADN. RNF2, miembro del complejo represor Polycomb 1 (PRC1, Polycomb repressive complex 1), forma un heterodímero con BMI1, dando lugar a una ubiquitina ligasa E3 que se une al dominio BRCT de NBS1 y se dirige a la región dañada para mediar la monoubiquitinación de las histonas H2A y H2AX en su lisina 119 (32). A continuación, otras dos ubiquitina ligasas E3, RNF8 y RNF168, que reconocen e interaccionan con la proteína MDC1 fosforilada, diubiquitinan y forman cadenas de poliubiquitina a través de la lisina 63, repectivamente, claves para el devenir de la reparación (Figura 5.B) $(30,31)$.

Tanto el reclutamiento y fosforilación de MDC1 como la formación de cadenas de ubiquitina en las histonas $\mathrm{H} 2 \mathrm{~A} / \mathrm{H} 2 \mathrm{AX}$ juegan un importante papel en la acumulación de las proteínas mediadoras 53BP1 (p53-binding protein 1) y BRCA1 (breast cancer associated 1) en los sitios dañados, que establecen el nexo de unión entre las proteínas sensoras y las implicadas en la reparación propiamente dicha. Además, el que se reclute una u otra determina el mecanismo de reparación que se activa, NHEJ o HR, que se explicarán más detalladamente en apartados posteriores. 
53BP1 se recluta a las DSBs a través de su interacción directa con proteínas implicadas en la respuesta al daño y con modificaciones concretas en la cola de las histonas. Esta proteína mediadora interacciona con $\mathrm{YH} 2 \mathrm{AX}$ y con MDC1, lo cual resulta indispensable para la formación de los focos de reparación $(94,95)$, pero su unión a la cromatina también depende de otras modificaciones en las histonas. Una de ellas es la dimetilación de la histona H3 en su lisina 79 (H3K79me2), reconocida específicamente por los dominios Tudor de 53BP1. DOT1L es la enzima encargada de catalizar esta dimetilación y Bat3 media la regulación de dicha enzima durante las fases G1 y G2 del ciclo celular (96). A su vez, la dimetilación de la lisina 20 de la histona H4 (H4K20me2) es importante en el reclutamiento de 53BP1. En este caso, son SET8 y MMSET quienes regulan este proceso. SET8 monometila la H4K20 en las regiones próximas a la rotura, y, posteriormente, la fosforilación de la serina 102 de MMSET, catalizada por ATM, favorece su unión a MDC1 y promueve la dimetilación de la H4K20 en los sitos dañados, punto de unión de 53BP1 a través de sus dominios Tudor $(97,98)$. Junto con estos residuos, el módulo Tudor-UDR de 53BP1 reconoce a la histona H2A ubiquitinada en su lisina 15 (H2AK15ub) en el contexto del nucleosoma, una reacción que depende de la ubiquitina ligasa RNF168 (99). Otras proteínas, como la chaperona de histonas ASF1a (anti-silencing factor 1a) también promueven el reclutamiento de 53BP1 y la reparación por NHEJ, al interaccionar con MDC1 y favorecer su fosforilación mediada por ATM (100). Además, ATM fosforila a 53BP1 en múltiples sitios S/T-Q (Serina/Treonina-Glutamina). La fosforilación de las serinas 25 y 29, que también son diana de la quinasa VRK1 (101), no son indispensables para la formación de focos de 53BP1 (94), mientras que la de la serina 1219 es absolutamente necesaria para la DDR y media la parada de ciclo en fase G2/M (102). El patrón de fosforilación de 53BP1 mediado por ATM es esencial también para el reclutamiento de RIF1, que inhibe la resección del ADN en fase G1 y que antagoniza con BRCA1 en fase S, promoviendo la reparación por NHEJ frente a la HR (Figura 5.C, dcha) (103).

El reclutamiento de 53BP1 a los sitios donde se ha producido la lesión en el ADN no sólo depende de la aparición de nuevas marcas epigenéticas necesarias para su unión a la cromatina, sino que, a su vez, requiere la desaparición de modificaciones preexistentes. Así, la deacetilación de la lisina 16 de la histona $\mathrm{H} 4$ es esencial para que 53BP1 pueda unirse a la H4K20me2, promoviendo la reparación por NHEJ e induciendo un bloqueo global de la transcripción (104). Además, estudios más recientes han demostrado que la deacetilación de la lisina 18 de la histona H3 mediada por la deacetilasa SIRT-7 también es necesaria para la acumulación de 53BP1 en las DSBs (105). 
En el caso de BRCA1, una ubiquitina ligasa E3, la cadena de poliubiquitinas formada en las histonas $\mathrm{H} 2 \mathrm{~A} / \mathrm{H} 2 \mathrm{AX}$ juega un papel fundamental, ya que recluta directamente a la subunidad RAP80 del complejo BRCA1-A. El nombre de este complejo se debe a una de sus proteínas, Abraxas, que se fosforila en la serina 404 vía ATM y forma un dímero estable con BRCA1, lo que permite su acumulación en la zona dañada (106). Esta ubiquitina ligasa también forma parte de otro complejo, BRCA1-C, denominado así por la presencia de la endonucleasa CtIP (CtBP interacting protein), diana de las quinasas ATM/ATR (69). La elección de la vía de reparación (HR o NHEJ) depende de cambios en la cromatina y CtIP participa activamente en este proceso. Esta endonucleasa se fosforila en la serina 327 vía ATM o dependiente de CDKs cuando las células entran en fase $S$ y es importante para la formación del complejo BRCA1CtIP-MRN, que, en su conjunto, media el procesamiento de los extremos del ADN durante la recombinación homóloga entre las fases S y G2 (107). A su vez, el complejo que forma BRCA1 con CtIP promueve la eliminación de las marcas metiladas y ubiquitinadas de la cromatina necesarias para el reclutamiento de 53BP1. De hecho, el que la reparación por HR sólo se produzca en las fases S/G2 del ciclo celular depende de la unión específica del complejo BRCA1-BARD1 (BRCA1associated RING domain protein 1) a la lisina 20 no metilada de la histona $\mathrm{H} 4$ (H4K20me0) en la cromatina post-replicativa (108). Además, la acumulación de la acetilación de la H4K16 (H4K16ac) mediada por Tip60 es necesaria para que BRCA1 se acumule en las zonas donde se ha producido la rotura e impide que 53BP1 se pueda unir a la H4K20me2 (Figura 5.C, izda) (109). Recientemente se ha visto también que BRCA1 favorece la reparación por HR al promover la defosforilación de 53BP1 mediada por la fosfatasa PP4C, lo que conlleva la liberación de RIF1 de las DSBs (110).

La activación en sí misma de BRCA1 depende de su fosforilación mediada por las quinasas ATM/ATR. Ambas quinasas fosforilan a BRCA1 en sus motivos SQ o TQ en respuesta al daño en el ADN, y, a su vez, ATM fosforila a Chk2 en la treonina 68. Esta fosforilación induce la dimerización de Chk2 y la trans-fosforilación de las treoninas 383 y 387 , que la activan completamente para que fosforile a sus sustratos, entre los que se encuentran las fosfatasas Cdc25 y otras proteínas como p53, PML, E2F-1 y BRCA1, asociadas a la parada del ciclo celular, el inicio de la reparación del ADN y la inducción de apoptosis en respuesta al daño génico. En el caso concreto de BRCA1, la fosforilación de su serina 988 es importante para disociarse de los focos de reparación y promover la reparación por HR (111). Además, ATM y ATR también fosforilan a la quinasa Chk1, que se une a los dominios BRCT de BRCA1 y la activa de manera indirecta (112). Aparte de ATM, ATR y las quinasas Chk, Plk1 (polo-like 
kinase 1) también fosforila a BRCA1, concretamente en el residuo de serina 1164, y promueve la HR (113).

\subsubsection{Vías de reparación de DSBs: recombinación homóloga (HR) y unión de extremos no homólogos (NHEJ)}

Como se ha mencionado en los apartados anteriores, la detección y señalización de las roturas de doble cadena o DSBs, así como la fase del ciclo celular en la que se produzca la lesión, determinan el mecanismo de reparación. Principalmente, estos mecanismos son la unión de extremos no homólogos (NHEJ) y la recombinación homóloga $(\mathrm{HR})$. La reparación mediante NHEJ puede llevarse a cabo en cualquier fase del ciclo celular, pero, al no utilizar molde, suele conducir a la aparición de deleciones, inserciones y/o translocaciones cromosómicas. Por su parte, la HR es un mecanismo de reparación más preciso al usar como molde a las cromátidas hermanas y solamente ocurre durante las fases $S$ y G2 del ciclo celular $(114,115)$. Minoritariamente, las DSBs también se reparan mediante otros dos mecanismos, la unión de extremos alternativa o a-EJ (alternative end joining), y el anillamiento de cadenas sencillas o SSA (single strand annealing) (116).

En la reparación por unión de extremos no homólogos, el heterodímero Ku70/Ku80 se une a los extremos de ADN generados y recluta dos subunidades de DNA-PKcs para formar el complejo DNA-PK, encargado de proteger y estabilizar dichos extremos. La activación de este complejo es importante para que se produzca la interacción entre Artemis y DNA-PKcs. Artemis tiene actividad exonucleasa 5'-3' y endonucleasa, independiente y dependiente de DNA-PKcs, respectivamente, responsables del procesamiento de los extremos de ADN para que posteriormente puedan volverse a ligar. Dicha ligación depende del complejo X4-L4, formado por las proteínas XRCC4, ADN ligasa IV y XLF. XRCC4 es catalíticamente inactiva, pero forma un homodímero que interacciona con Ku y con el ADN. Además, tanto XRCC4 como XLF estimulan la actividad de la ADN ligasa IV, que es capaz de unir tanto extremos romos como cohesivos (Figura 6, izda) $(114,117)$. Cabe destacar también el papel de las polimerasas Pol $\mu$ y Pol $\lambda$ en este proceso, ya que son capaces de incorporar nucleótidos de manera dependiente o independiente de molde, y su actividad podría explicar el alto grado de diversidad en las uniones generadas por NHEJ (116). 
Unión de extremos no homólogos (NHEJ)
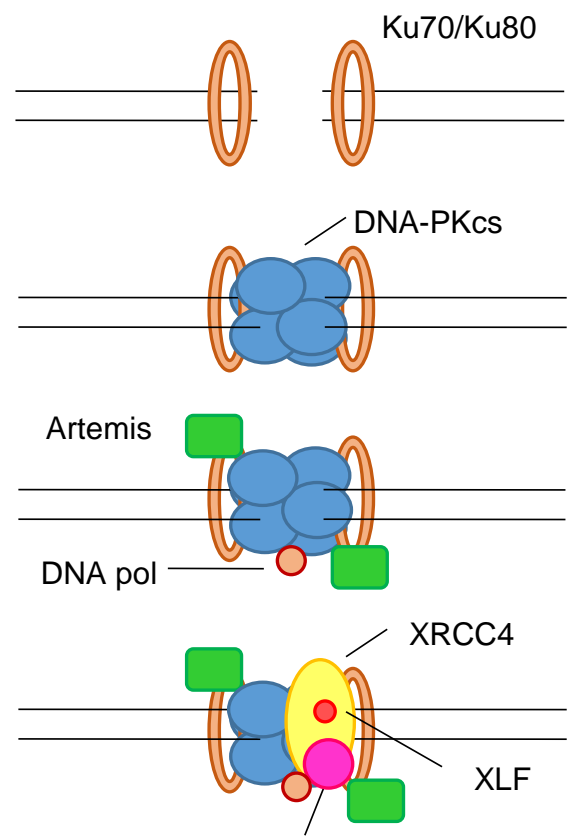

Lig IV

\section{Recombinación homóloga (HR)}
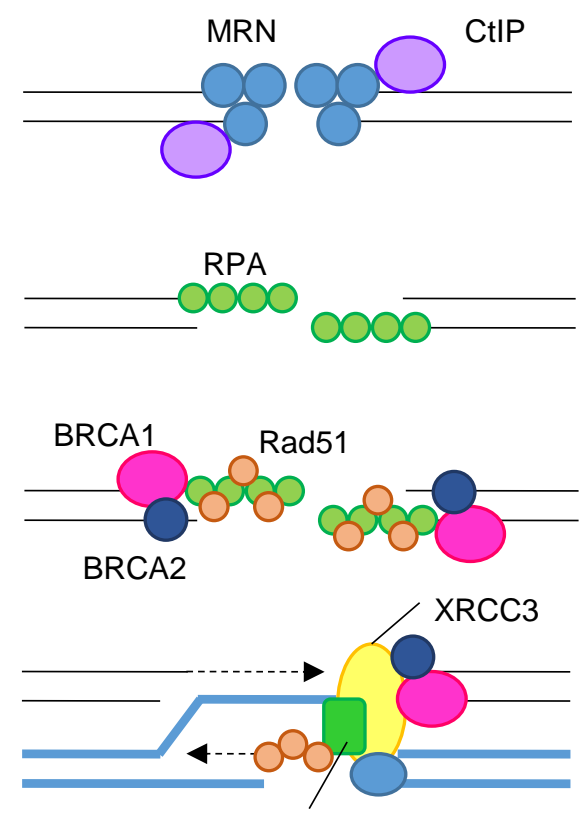

Rad54

Figura 6: Esquemas representativos de los dos principales mecanismos de reparación de roturas de doble cadena, unión de extremos no homólogos (NHEJ) y recombinación homóloga (HR). Adaptado de (118).

En el caso de la recombinación homóloga, es el complejo MRN el que se une a los extremos generados tras la rotura. A continuación, este complejo, junto con CtIP, la helicasa BLM y la nucleasa Exo1, procesan los extremos en dirección 5'-3', generando hebras de ADN de cadena sencilla que se unen a la proteína RPA para evitar que se formen estructuras secundarias. En este punto, se tiene que formar también un nucleofilamento constituido por multímeros de la recombinasa Rad51 con cadenas sencillas de ADN. Rad51 interacciona entonces con Rad52, y Rad54 es la encargada de estabilizar dicha interacción y potenciar su propia actividad catalítica, necesaria para la formación de dicho nucleofilamento. Dado que la afinidad de RPA por el ADN monocatenario es mayor que la de Rad51, los complejos BRCA1/BARD1 y BRCA2/DSS1, utilizando probablemente a PALB2 como puente, actúan como mediadores de este proceso y son capaces de desplazar a RPA del ADN de cadena sencilla. Aunque todas esas proteínas son necesarias para el reclutamiento de Rad51, 
es BRCA2 la que está unida a ella cuando es inactiva y, en respuesta al daño, esta unión desaparece cuando Rad51 se fosforila y comienza a sintetizarse el nucleofilamento. Seguidamente, este nucleofilamento invade el ADN bicatenario de la cromátida hermana en busca de su secuencia homóloga y se forma el lazo $\mathrm{D}$ ( $D$-loop, displacement loop), en el que pueden entrar uno o los dos extremos 3' producidos tras la rotura. Este intermediario precede a las uniones Holliday (HJ, Holliday junctions) entre el nucleofilamento y la hebra que actúa como molde, que son estructuras en forma de $X$ que se van desplazando a medida que el $A D N$ se va sintetizando a partir del extremo 3' libre, generándose un ADN heterodúplex de longitud variable que depende de la dirección en la que se desplace la unión. Rad54 es la proteína que media este desplazamiento en dirección 5'-3' o viceversa, mediante un proceso que consume ATP. En el caso de que los dos extremos 3' entren en la estructura del lazo D, se forman dos uniones Holliday y puede producirse sobrecruzamiento entre el molde y la cadena sintetizada, aunque este supuesto no suele ser muy frecuente (117). Finalmente, la resolución de las HJ puede llevarse a cabo mediante dos mecanismos en los que participan distintos complejos. En el primero, la helicasa BLM se transloca a las $\mathrm{HJ}$ adyacentes para que la topoisomerasa IIla las escinda completamente. El segundo, mediado por el complejo SLX1-SLX4MUS81-EME1, implica la acción de dos nucleasas. En primer lugar, SLX1 realiza una única escisión y es MUS81-EME1 quien lleva a cabo la segunda, siendo la proteína SLX4 el punto de unión entre ambas nucleasas. (Figura 6, dcha) (119).

Sea cual sea el mecanismo utilizado para la reparación del daño, las células deben regresar a su estado basal. Esto implica, por un lado, el desensamblaje de las estructuras de reparación, revirtiendo las modificaciones postraduccionales asociadas a la acumulación focal de las proteínas que median la DDR (50), y, por otro, la síntesis de nuevos nucleosomas que permitan empaquetar al ADN sintetizado en fibras de cromatina y la eliminación de las marcas epigenéticas de las regiones próximas al punto donde se produjo la lesión, esencial para la inactivación de la DDR y para que las células puedan volver a dividirse (69).

\subsection{Daño génico y cáncer}

La DDR juega un papel fundamental en la fisiología humana, ya que, tanto la acumulación de daño génico como las mutaciones en genes implicados en DDR, conllevan la aparición de enfermedades genéticas que afectan a la homeostasis celular y predisponen al desarrollo del cáncer y al envejecimiento prematuro (59). 
El desarrollo de tumores en humanos se basa, principalmente, en la capacidad que tienen sus células de proliferar de forma continuada, evadir las señales que bloquean el crecimiento, impedir que se activen los mecanismos de muerte celular, favorecer la inmortalidad replicativa, inducir la angiogénesis, activar los procesos de invasión y metástasis, modificar el metabolismo celular y eludir al sistema inmune. Detrás de estas características se encuentra la inestabilidad genómica, responsable de generar diversidad genética, y la inflamación, ambas necesarias para la aparición y progresión del tumor (120). Precisamente, los tratamientos contra el cáncer más prevalentes, quimioterapia y radioterapia, generan daño e inestabilidad genómica (52). Sin embargo, las células tumorales han desarrollado mecanismos que regulan positivamente algunos de los componentes implicados en la DDR para compensar la acumulación de daño génico. Por eso, se han desarrollado inhibidores específicos de las distintas vías de reparación del ADN, que, en combinación o por defectos en la reparación propios de las células tumorales, incrementan significativamente su potencial terapéutico. A esta estrategia basada en el bloqueo de dos o más rutas de reparación del ADN para inducir muerte celular se le denomina letalidad sintética (121, 122).

Diversos estudios demuestran también la capacidad de los tumores para alterar su inmunogenicidad y así impedir que sus células sean reconocidas por el sistema inmune. En base a estos descubrimientos, las nuevas estrategias contra el cáncer se focalizan en la identificación de nuevos antígenos tumorales que puedan utilizarse como diana en inmunoterapia. Además, estos tratamientos son más eficaces y resultan menos tóxicos para los pacientes que la quimioterapia y la radioterapia actuales (123). Con el objetivo de mejorar aún más las terapias, se ha comenzado a combinar la inmunoterapia con los inhibidores de la DDR, ya que dichos inhibidores aumentan la carga mutacional de las células cancerosas y vuelven a los tumores más inmunogénicos (122).

\subsubsection{Inhibidores de PARP en el tratamiento del cáncer}

La familia de polimerasas PARP (poly-ADP ribose polymerase) está compuesta por 18 miembros y PARP1 fue el primero que se identificó. La principal reacción catalizada por PARP1 es la polimerización de unidades de ADP-ribosa sobre sí misma o en otras proteínas diana. Es una enzima altamente conservada que consta de 3 dominios principales: un dominio de unión al ADN (DBD, DNA-binding domain) con motivos de dedo de zinc, uno central de automodificación, que contiene un motivo de interacción BRCT, y un dominio catalítico C-terminal. Esta enzima tiene multitud de funciones asociadas a la respuesta al daño en el ADN: juega un papel importante en 
la reparación de roturas de cadena sencilla mediante el mecanismo de escisión de bases, participa en la detección de las DSBs y en su reparación por HR, NHEJ o a-EJ, mantiene y estabiliza las horquillas de replicación, y modula la estructura de la cromatina en procesos celulares como la replicación, la transcripción o la DDR (Figura 7) (124).

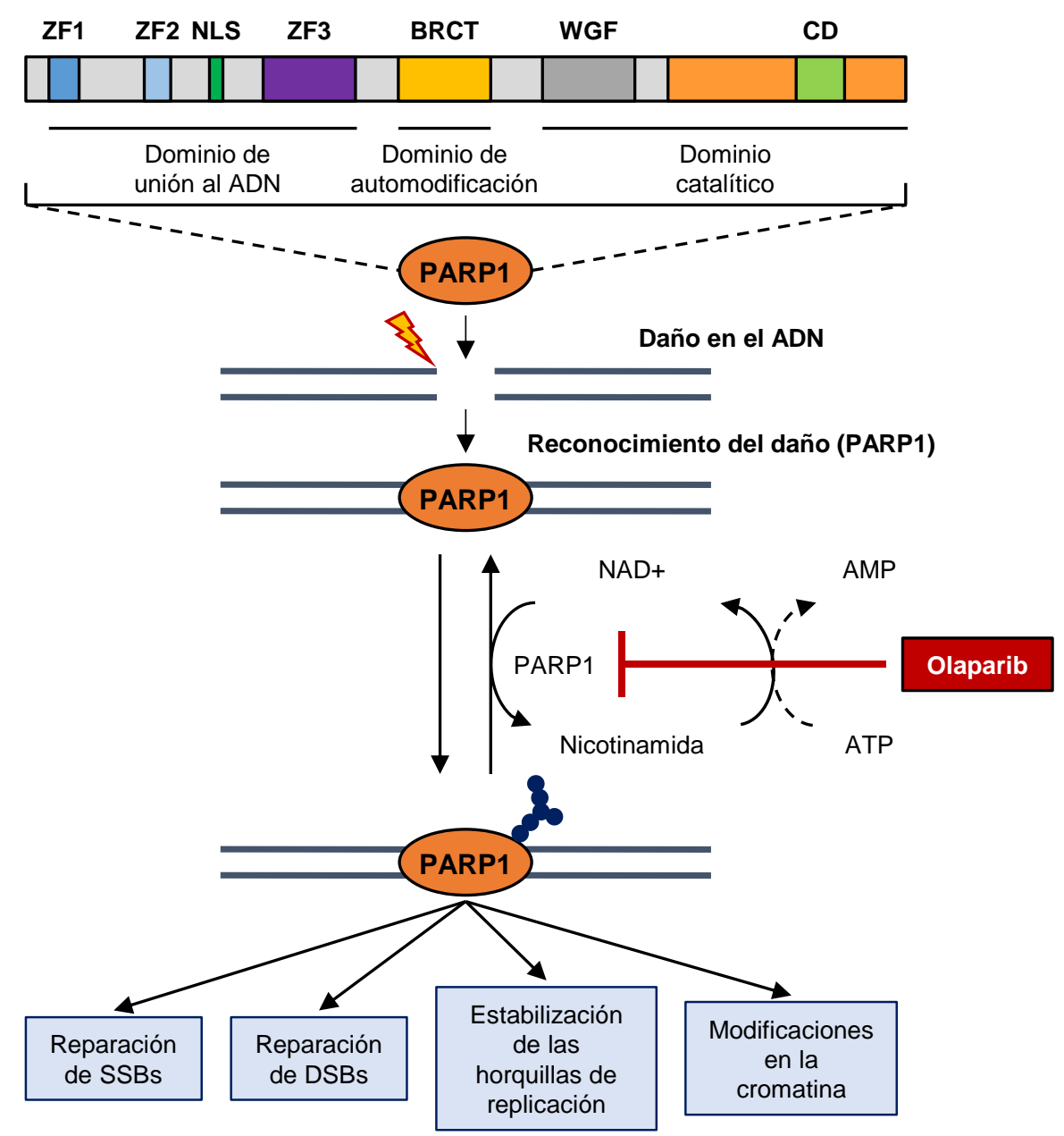

Figura 7: Estructura de PARP1 y su implicación en distintas respuestas celulares. Adaptado de (124).

En base al papel que juega PARP1 en la respuesta al daño en el ADN, esta polimerasa ha sido ampliamente utilizada como diana terapéutica. Inhibidores específicos de PARP1 como el olaparib (AZD2281) sensibilizan a las células tumorales a la radiación ionizante (125), lo que conduce a la muerte celular debido a la acumulación de DSBs (126). 
El olaparib se ha empleado en monoterapia o terapia combinativa en distintos tipos de cáncer y sobre distintos fondos genéticos, destacando los tumores de mama y ovario con mutaciones en $B R C A 1 / 2(127,128)$. También se ha descrito que los tumores que carecen de ATM se vuelven más sensibles al tratamiento con inhibidores de PARP como el olaparib $(129,130)$. Sin embargo, las estrategias clínicas actuales basadas en el uso de estos inhibidores van más allá de tumores que tienen mutados $B R C A$ o que presentan defectos en recombinación homóloga, e incluyen desde su utilización en quimioterapia neoadyuvante, adyuvante o en quimioprevención, hasta su combinación con inhibidores de ATR, de proteínas implicadas en los checkpoints del sistema inmune y de proteínas no relacionadas con la DDR que mimetizan químicamente la ausencia de BRCA (131). 


\section{LAS PROTEÍNAS QUINASA}

La fosforilación de las proteínas es una modificación postraduccional que se basa en la unión covalente de un grupo fosfato a residuos de serina, treonina o tirosina de la proteína diana específica. Las enzimas encargadas de catalizar estas reacciones son las proteínas quinasa y se caracterizan por mostrar una alta homología en su dominio quinasa, también conocido como dominio catalítico, constituido por una secuencia de entre 250 y 300 aminoácidos (132). La conservación de esta secuencia pone de manifiesto la importancia de esta modificación covalente en la regulación de procesos celulares como el metabolismo, el crecimiento, la proliferación, la diferenciación, la supervivencia, la migración o la reparación del ADN (27). Además, podemos decir que esta reacción es reversible gracias a la existencia de las proteínas fosfatasas, responsables de la eliminación del grupo fosfato de las proteínas previamente añadido por una quinasa.

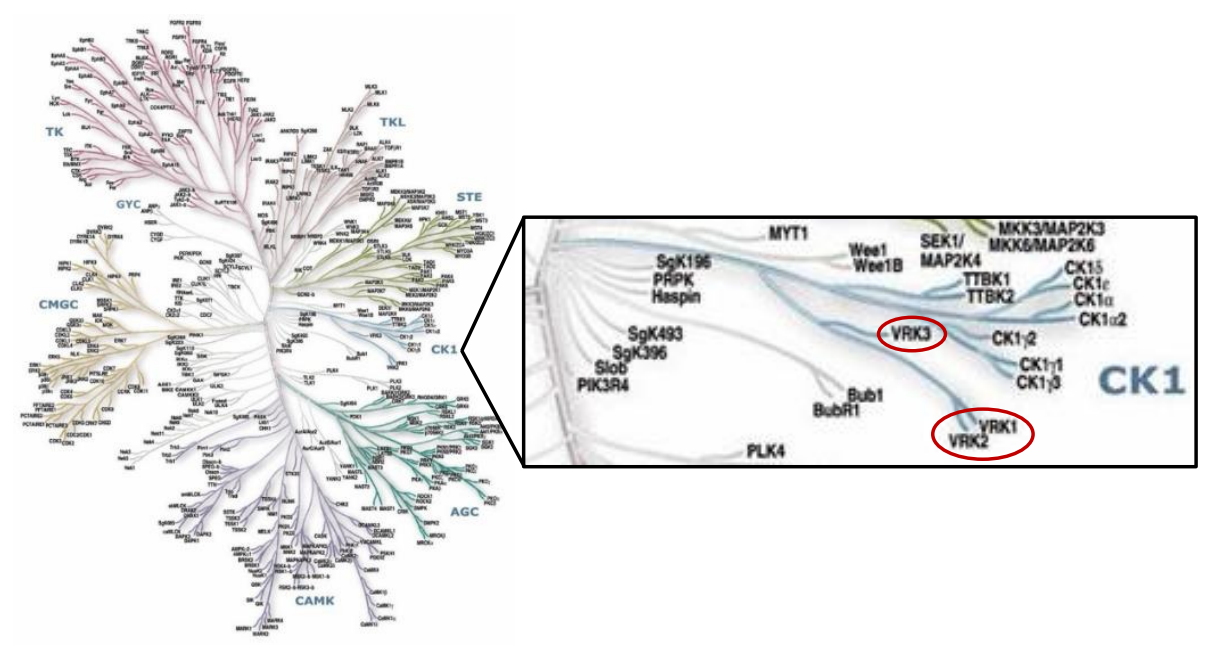

Figura 8: Representación esquemática del quinoma humano. Se muestra con más detalle el grupo de las caseín quinasas de tipo 1, en el que se encuentra la familia de quinasas VRK. Adaptado de (133).

En el año 2002, Manning y su grupo de investigación catalogaron filogenéticamente todas las quinasas humanas en lo que se denominó el "quinoma humano", tomando como punto de partida las bases de datos genómicas disponibles, los ADN codificantes (ADNc) y las EST (expression sequences tags) (133). En esta nueva clasificación, una ampliación de la llevada a cabo previamente por Hanks y Hunter en 1995, se identificaron 518 quinasas potenciales y 106 pseudogenes (copias no 
funcionales), y se incorporaron cuatros nuevos grupos. Entre ellos, cabe destacar el de las caseín quinasas de tipo 1 (CK1), que engloba a la familia de quinasas VRK (Vaccinia-related kinases) (Figura 8).

\subsection{La familia de quinasas VRK}

Esta familia de quinasas humanas consta de tres miembros, VRK1 y VRK2, y la pseudoquinasa VRK3. En 1997, Nezu y sus colaboradores identificaron la quinasa humana VRK1 a través de una librería enriquecida en ADNc fetales de hígado humano, diseñada con el objetivo de conocer nuevos reguladores de la división celular en células con altas tasas de proliferación. A continuación, utilizando la secuencia completa de VRK1 y las bases de datos de EST disponibles, identificaron un nuevo miembro de la familia, VRK2. Estos mismos investigadores denominaron a esta familia de quinasas Vaccinia-related kinases (VRKs) por su homología con la quinasa B1R del virus Vaccinia, implicada en la replicación del genoma viral. En el caso de VRK1, esta homología era del 39\%, mientras que VRK2 mostraba un 36\% (134). El tercer miembro de la familia, VRK3, no fue descubierto hasta 2003, también mediante el uso de bases de datos de ADNc (135). Inicialmente, se consideró que sólo las quinasas VRK1 y VRK2 eran catalíticamente activas, ya que VRK3 era una pseudoquinasa con mutaciones en aminoácidos clave en el dominio catalítico y que era incapaz de unir ATP (136). Sin embargo, estudios más recientes demuestran la capacidad que tiene VRK3 de fosforilar sustratos siguiendo un mecanismo no canónico, al igual que ocurre con otras pseudoquinasas (137).

Desde un punto de vista evolutivo, se cree que la familia de quinasas VRK surgió a partir de un único gen $V R K$ que se duplicó a lo largo de la evolución en la rama de los vertebrados, de forma que en organismos invertebrados sólo encontramos un gen $V R K$, a diferencia de los tres presentes en vertebrados (138). No se han encontrado genes ortólogos en levaduras. Sin embargo, se conocen dos isoformas de CK1 en estos organismos, los genes Hrr25 en Saccharomyces cerevisiae y su ortólogo en Schizosaccharomyces pombe, hhp1, que codifican proteínas implicadas en la respuesta al daño $(139,140)$. En el nematodo Caenorhabditis elegans existe un único ortólogo, VRK-1, que juega un papel importante en la proliferación normal de la línea germinal y regula la actividad de CEP-1, ortólogo de p53 (141). VRK-1 también fosforila a BAF (barrier-to-autointegration factor) y regula su localización y función, claves en el proceso de división celular, ya que esta proteína actúa como nexo entre la cromatina y la envuelta nuclear (142). Además de la regulación de CEP-1 y BAF, se ha descrito más recientemente que este nematodo expresa el gen VRK-1 en distintos 
tipos celulares y que participa en la proliferación y diferenciación de las células uterinas, poniendo en relieve el papel de las quinasas VRK en la organogénesis (143). Otro de los organismos en los que se puede encontrar un ortólogo del gen VRK1 es la mosca de la fruta, Drosophila melanogaster, y se denomina NHK-1. Se ha descrito el papel de esta quinasa en la fosforilación de la histona H2A en la treonina 119 (T119) durante la mitosis, pero no en la fase $S$ del ciclo celular (144). Sin embargo, éste no es el único sustrato conocido para NHK-1, ya que se ha descubierto que también fosforila a BAF, lo que permite la separación de los cromosomas de la envoltura nuclear y la posterior formación del cariosoma (145). Por su parte, en ratones (Mus musculus), encontramos tres ortólogos, al igual que en el ser humano. El primero de los miembros descubierto en esta especie se denominó 51PK y se describió como una quinasa nuclear con altos niveles de autofosforilación en residuos de serina (146). Estas tres quinasas murinas se expresan principalmente durante la etapa embrionaria y en órganos con alta tasa de proliferación como el hígado, el bazo o el timo fetal (146).

\subsection{Estructura de las quinasas VRK}

Cada uno de los tres miembros de la familia de quinasas VRK se localiza en regiones diferentes del genoma humano. El gen correspondiente a la quinasa VRK1 se encuentra en la región cromosómica 14q32.2 y codifica una proteína de 396 aminoácidos. En su extremo N-terminal se localizan el sitio de unión al ATP (residuos 43-71) y el dominio quinasa activo (residuos 173-185), altamente conservado entre especies $(138,147)$. En la región C-terminal encontramos un dominio básico-ácidobásico (BAB, residuos 356-396) (144) y las señales de importe (NLS, residuos 356360) (136) y exporte nuclear (NES). Esta región C-terminal no presenta homología con el resto de proteínas de la familia y se cree que juega un importante papel regulador (147). Además, se ha demostrado que esta región C-terminal es esencial para la estabilidad estructural de la proteína y para su actividad autocatalítica (148).

El gen VRK2 se localiza en la región cromosómica 2p16.1 y codifica dos isoformas generadas por procesamiento alternativo: VRK2A, de 508 aminoácidos, y VRK2B, de 397. La parte $\mathrm{N}$-terminal de ambas isoformas contiene, al igual que la quinasa VRK1, el sitio de unión al ATP (residuos 35-61) y el dominio quinasa activo (residuos 162 174). Sin embargo, el extremo C-terminal difiere considerablemente entre ambas. En el caso de VRK2A, la región comprendida entre los aminoácidos 395 y 508 contiene dos dominios $B A B$ solapados y una región transmembrana hidrofóbica (residuos 492 - 
508), mientras que VRK2B sustituye dicha región por un triplete VEA (ValinaGlutámico-Alanina) (149).

Las proteínas humanas VRK1 y VRK2 presentan una homología del 44\%, que se reducen al 33 y $23 \%$ respectivamente al compararlas con el tercer miembro de la familia, VRK3 (136). El gen que codifica esta pseudoquinasa se encuentra en la región 19q13.33 y consta de 474 aminoácidos, aunque puede generar una variante de 424 aminoácidos por la pérdida del exón 4 (136). En su región $\mathrm{N}$-terminal se encuentra una secuencia de localización nuclear bipartita (NLS, residuos 49-64) (136) y en su extremo C-terminal, el dominio catalítico (residuos 148-472), que, estructuralmente hablando, es muy similar al de la quinasa VRK2 (residuos 15-330) (150).

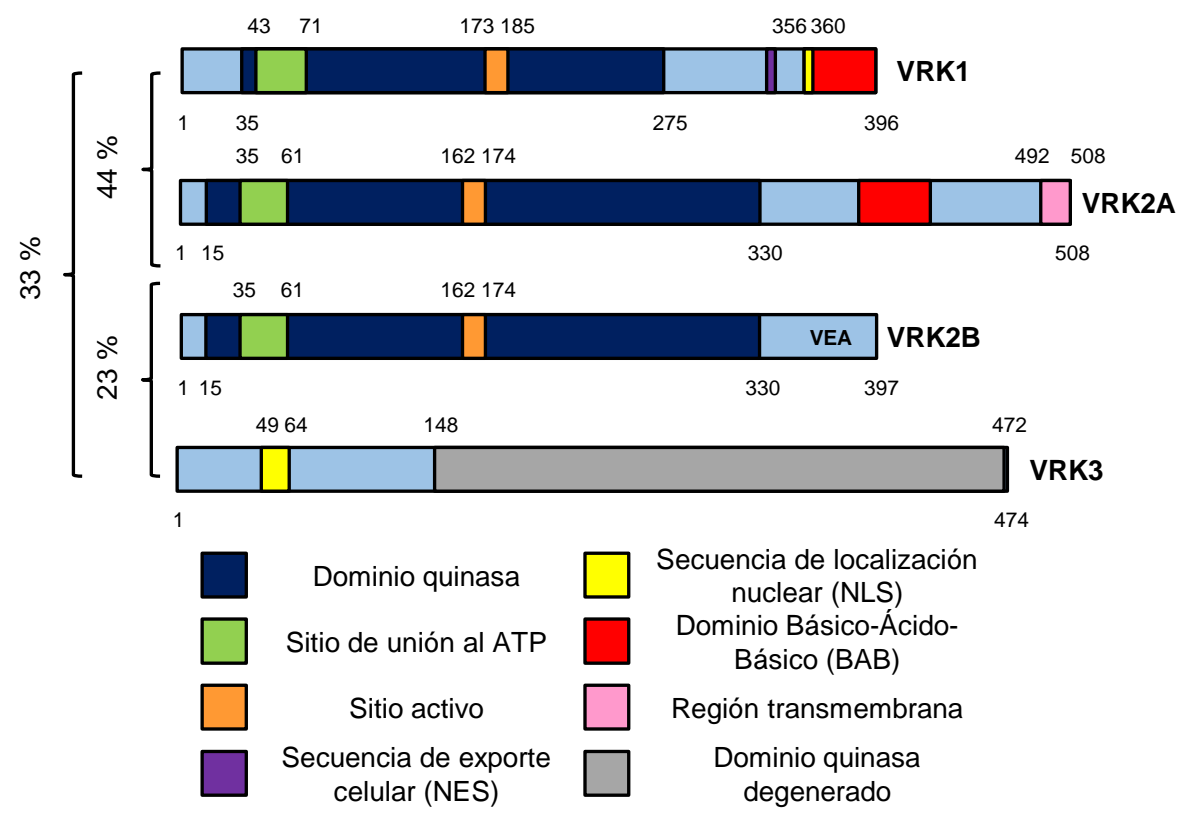

Figura 9: Estructura esquemática de las quinasas VRK, indicando los principales motivos y dominios, y el porcentaje de homología entre los tres miembros de la familia.

La mayoría de las quinasas presentan en su estructura un loop de activación situado en el dominio catalítico, que tiene que fosforilarse para que la proteína se vuelva activa. Esto no ocurre en las quinasas VRK, ya que poseen una hélice adicional ( $a \mathrm{C} 4)$ en este segmento de activación que les permite mantener una conformación cerrada constitutivamente activa (150). Al margen de esta característica, VRK3 presenta modificaciones en dominios clave para su actividad catalítica. Uno de ellos es el Gloop (GxGxfG), una región rica en glicinas necesaria para la unión del ATP, donde 
VRK3 sustituye estas glicinas por aminoácidos de mayor tamaño. También se ha

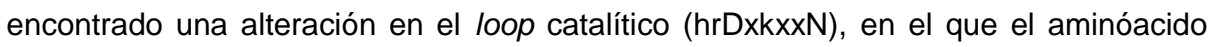
aspártico (D) se sustituye por asparagina (N). Pero, además de todo esto, presenta una sustitución en el motivo DYG previo al loop de activación, donde el aspártico (D) pasa a ser una glicina $(G)$, y la pérdida del aminoácido aspártico en el dominio de unión al metal (DFG). Por tanto, todos estos datos parecían indicar que la pseudoquinasa VRK3 sería inactiva por su incapacidad de unir ATP, la imposibilidad de orientar correctamente el sustrato en el sitio catalítico y los problemas asociados a la transferencia de los grupos fosfato (150). Ahora bien, estos estudios estructurales se realizaron con el dominio catalítico de VRK3 (residuos 148-472), localizado en el extremo C-terminal, sin tener en cuenta la región $\mathrm{N}$-terminal (residuos 1-147). Trabajos posteriores demostraron la capacidad de VRK3 para fosforilar sustratos gracias al dominio extra-catalítico $\mathrm{N}$-terminal y al dominio quinasa, necesarios para interaccionar con el sustrato y adquirir la conformación necesaria para poder fosforilarlo (137).

\subsection{La quinasa VRK1}

La quinasa VRK1 es el miembro mejor caracterizado de la familia de quinasas VRK. Se expresa de manera ubicua en todos los tejidos analizados, pero los mayores niveles de ARN mensajero (ARNm) se detectan en aquellos con alta tasa de proliferación, como el hígado, el timo, los testículos fetales y las líneas celulares tumorales (134).

\subsubsection{Localización subcelular de VRK1}

Debido a su secuencia de localización nuclear, VRK1 se encuentra principalmente en el núcleo, libre en el nucleoplasma o asociada a la cromatina (136, 147, 151-153). De hecho, se sabe que esta quinasa forma parte de complejos transcripcionales y que está asociada a la cromatina junto con histonas y factores de ensamblaje (154). Además, en algunas ocasiones, VRK1 puede encontrarse "secuestrada" en el nucleolo (155).

Asimismo, es importante tener en cuenta que la localización subcelular de VRK1 puede variar en función de la línea celular y de las condiciones de crecimiento, pudiéndose encontrar a VRK1 en el citoplasma. También cabe destacar la presencia de subpoblaciones de VRK1 en el aparato de Golgi (153). 


\subsubsection{Papel de VRK1 en proliferación y progresión del ciclo celular}

Diversos estudios han puesto de manifiesto la implicación de VRK1 en proliferación y progresión del ciclo celular. En primer lugar, se demostró que el silenciamiento de esta quinasa estaba directamente relacionado con defectos en proliferación, ya que las células carentes de VRK1 eran incapaces de completar el proceso de división normal, posiblemente por el papel que juega esta quinasa en la estabilización y el control de los niveles basales de p53 en ausencia de estrés (151).

En epitelios escamosos normales, los mayores niveles de expresión de VRK1 se encontraron en la capa basal, donde preferentemente proliferan las células, mientras que dichos niveles se iban reduciendo a medida que aumentaba la diferenciación del tejido epitelial. Además, el análisis de muestras de tumores escamosos de cabeza y cuello reveló una correlación positiva entre VRK1 y marcadores de proliferación como CDK2, CDK6, CB1N (ciclina B1 nuclear), topoisomerasa II, survivina, Cdc2, Ki67 o ciclina A, y negativa con p21 (156). A su vez, los niveles de esta quinasa se correlacionan con los de p63 en el epitelio escamoso de la faringe, ya que ambos van disminuyendo progresivamente hasta desaparecer completamente en células diferenciadas (157).

También se ha visto que VRK1 es necesaria para la salida de fase G0 y entrada en el ciclo celular, siendo un elemento de respuesta temprana en la fase G1. De hecho, los cambios en los niveles proteicos de VRK1 están íntimamente relacionados con los de marcadores positivos de ciclo como Rb fosforilado o PCNA, mientras que muestran una correlación negativa con inhibidores de ciclo celular como p27 $(157,158)$.

\subsubsection{Importancia de VRK1 en el ensamblaje de la envuelta nuclear}

La envuelta nuclear es una estructura dinámica que se desensambla durante las primeras etapas de la mitosis y que se reconstruye en torno a los cromosomas durante la telofase, restableciendo la arquitectura nuclear antes de iniciar la siguiente interfase en cada una de las células hijas (159). Este proceso implica la regulación de multitud de proteínas, entre las que se encuentra BAF (barrier to-autointegration factor), esencial en el mantenimiento de la estructura nuclear.

Se ha visto que la quinasa humana VRK1 fosforila la región N-terminal de BAF en el residuo de serina 4 y, de forma no tan efectiva, en las treoninas 2 y 3 (Figura 10). Estas fosforilaciones impiden la unión de BAF al ADN y afectan, en menor medida, a su capacidad para unirse a las proteínas con dominios LEM. Esto explicaría los cambios de localización subcelular de BAF, que se encuentra en el núcleo cuando no 
está fosforilada, uniendo el ADN a la membrana nuclear, mientras que la fosforilación mediada por VRK1 favorece la condensación de la cromatina y el desensamblaje de la envuelta nuclear, eventos clave que hacen que BAF adquiera una localización difusa durante las primeras etapas de la mitosis (160). A su vez, estudios más recientes han demostrado que el silenciamiento de VRK1 reduce drásticamente los niveles de fosforilación de BAF, lo que conduce, por una parte, a la formación de una envoltura nuclear aberrante durante la interfase y, por otra, a la deslocalización de BAF, que pasa a interaccionar de manera atípica con los cromosomas mitóticos (161). En conjunto, todos estos datos ponen de manifiesto el papel que juega VRK1 en el correcto mantenimiento de la arquitectura nuclear.

\subsubsection{VRK1 en la fragmentación del aparato de Golgi}

El aparato de Golgi, al igual que ocurre con otros orgánulos celulares, tiene que fragmentarse en pequeñas vesículas durante las fases G2/M del ciclo celular para poder repartirse a las células hijas. Se sabe que este proceso depende de fosforilaciones reversibles mediadas por serina/treonina quinasas, entre las que destacan MEK1 (mitogen-activated protein kinase 1) y PIk3 (polo-like kinase 3) (162, 163).

En este contexto, Plk3 es capaz de fosforilar a VRK1 en su región C-terminal, más concretamente, en el residuo de serina 342 (Figura 10). Además, ambas proteínas interaccionan a través de la región N-terminal de VRK1 (residuos 1-267) y colocalizan en el aparato de Golgi. Para estudiar el papel de VRK1 en la fragmentación del aparato de Golgi, se llevaron a cabo experimentos de silenciamiento de VRK1 y de expresión de mutantes de VRK1 K179E (inactivo) o con el residuo de serina 342 mutado (S342A, no fosforilable por Plk3), en los que se vio que dicha fragmentación no se podía llevar a cabo cuando VRK1 no es funcional o no es capaz de activarse por Plk3 (164). Esto demuestra que la correcta fragmentación del aparato de Golgi en las fases G2/M depende de la vía MEK1-PIk3-VRK1.

\subsubsection{Regulación de factores de transcripción mediada por VRK1}

Dentro de los sustratos conocidos de la quinasa humana VRK1 se encuentran varios factores de transcripción. El mejor caracterizado es p53, también conocido como "el guardián del genoma", esencial en el mantenimiento de la homeostasis celular. VRK1 se autofosforila y fosforila a p53 en la treonina 18, localizada en su dominio de transactivación (Figura 10). Esta modificación postraduccional favorece la acumulación y estabilización de p53 al impedir su unión a la ubiquitina ligasa Mdm2 y 
evitar así su consecuente degradación vía proteasoma, y al favorecer su unión al cofactor p300, con el que forma un complejo y que se activa y acetila a las lisinas 373 y 382 de p53, promoviendo su actividad transcripcional $(147,151,165)$. Por otro lado, se sabe que p53 regula negativamente los niveles proteicos de VRK1 y que este efecto se revierte al silenciar este factor de transcripción, definiendo un loop de autorregulación entre ambos (166). Esto se debe a que la activación de p53 induce la expresión de DRAM (damage-regulated autophagy modulator), responsable de la degradación de VRK1 por vía endocítica-lisosomal (167). Esta regulación negativa de VRK1 se revierte cuando cofactores que contienen el dominio $\mathrm{C} / \mathrm{H} 3$, como p300 o $\mathrm{CBP}$, compiten por su unión a p53 con aquellos que indirectamente median la degradación de VRK1 (168).

Otro de los factores regulados por VRK1 es ATF2 (activating transcription factor 2), un factor de activación dependiente de AMPc. VRK1 es capaz de fosforilar específicamente los residuos de serina 62 y treonina 73 de ATF2, promoviendo su acumulación en la célula y su activación transcripcional (Figura 10) (169).

VRK1 también regula por fosforilación al factor de transcripción c-Jun, en este caso, en las serinas 63 y 73 (Figura 10). Al igual que ocurría con ATF2, estas fosforilaciones estabilizan la proteína y la activan, promoviendo su actividad transcripcional. Estos mismos residuos son, a su vez, diana de la quinasa JNK (c-Jun $\boldsymbol{N}$-terminal kinase), la cual colabora con VRK1 en el proceso de activación transcripcional mediado por c-Jun (170).

Dentro de la familia de los factores de transcripción ATF, VRK1 fosforila no sólo a ATF2, como se ha mencionado anteriormente, sino que también interacciona y fosforila a la proteína CREB (CRE-binding protein) en la serina 133 (Figura 10). Cuando VRK1 fosforila y activa a estos dos factores de transcripción, éstos se unen a las regiones CRE (cAMP-response element) del promotor del gen de la ciclina 1 (CCND1) y promueven la transición de fase $\mathrm{G} 1$ a $\mathrm{S}$ del ciclo celular. Además, la sobreexpresión de Myc, factor de transcripción clave en crecimiento celular y proliferación, conduce a un aumento en los niveles de VRK1 y, por tanto, a una mayor expresión del gen CCND1 (171).

\subsubsection{VRK1 y la fosforilación de histonas}

Las histonas, ya sean las que forman el nucleosoma (H2A, H2B, H3 y H4) o sus variantes, sufren modificaciones postraduccionales en sus extremos amino $y$ carboxilo, entre las que caben destacar acetilación, metilación, fosforilación y 
ubiquitinación (22). Todas ellas están coordinadas y regulan procesos celulares como la replicación, la condensación de los cromosomas durante la mitosis, la transcripción, la respuesta al daño génico o la apoptosis $(22,43,172-175)$.

VRK1 es una quinasa de la cromatina que fosforila la treonina 3 (diana de Haspin) y la serina 10 (en cooperación con la quinasa Aurora B) de la histona H3 tanto in vitro como in vivo (Figura 10) (152). Estos residuos son clave en el proceso de condensación de la cromatina durante la mitosis, aunque también se ha descrito el papel que juega la fosforilación de la serina 10 en la relajación de la cromatina en interfase, asociado a otras modificaciones covalentes como las acetilaciones de las lisinas 9 y 14 de esa misma histona (176). Además, la quinasa VRK1 también es capaz de fosforilar, aunque en menor medida que a la H3, a las histonas $\mathrm{H} 2 \mathrm{~A}, \mathrm{H} 2 \mathrm{~B}$ y H4. Estos datos demuestran que la fosforilación de histonas mediada por VRK1 podría tener un papel esencial en la condensación de la cromatina durante la transición G2/M (152).

Estudios más recientes han caracterizado la relación entre VRK1 y Aurora B. Estas dos quinasas forman un complejo proteico, principalmente en mitosis, el cual inhibe de forma cruzada a ambas quinasas. Además, el silenciamiento de VRK1 impide la correcta formación de los centrómeros, altera la localización centromérica de Aurora B y reduce significativamente los niveles de expresión del gen que codifica para la survivina, proteína implicada en el reclutamiento de Aurora B (177).

La histona H2AX es otro de los sustratos de VRK1. Esta quinasa interactúa con H2AX y la fosforila en la serina 139 ( $\mathrm{H}$ H2AX) (Figura 10). Esta fosforilación, mediada también por ATM (178), juega un importante papel en la detección de las roturas de doble cadena en el ADN. Sin embargo, el efecto de VRK1 sobre la fosforilación de H2AX y la consecuente formación de focos de reparación en respuesta al daño génico inducido por radiación ionizante es independiente de ATM (85).

También la histona H2A es diana de VRK1. Esta quinasa fosforila la treonina 120 de dicha histona tanto in vitro como in vivo en líneas celulares normales y tumorales (Figura 10). Al estudiar esta modificación covalente en el promotor de gen CCND1 (ciclina D1), se vio que la ausencia de VRK1 conllevaba una pérdida de expresión de esta ciclina y una disminución significativa del crecimiento celular. Este efecto se debía a que el silenciamiento de esta quinasa iba acompañado de una reducción de la fosforilación en la H2AT120, que está íntimamente relacionado con un aumento en la ubiquitinación de H2A en el residuo 119 (H2AK119ub), y una disminución de la trimetilación de la histona $\mathrm{H} 3$ en la lisina 4 (H3K4me3), asociadas a represión y 
activación transcripcional, respectivamente. Además, ha quedado demostrado que VRK1 por sí misma y la mutación fosfomimética de la histona H2A, T120D, que mimetiza la fosforilación mediada por esta quinasa, son capaces de transformar células NIH/3T3 in vitro, lo que pone de manifiesto su implicación en la carcinogénesis (179).

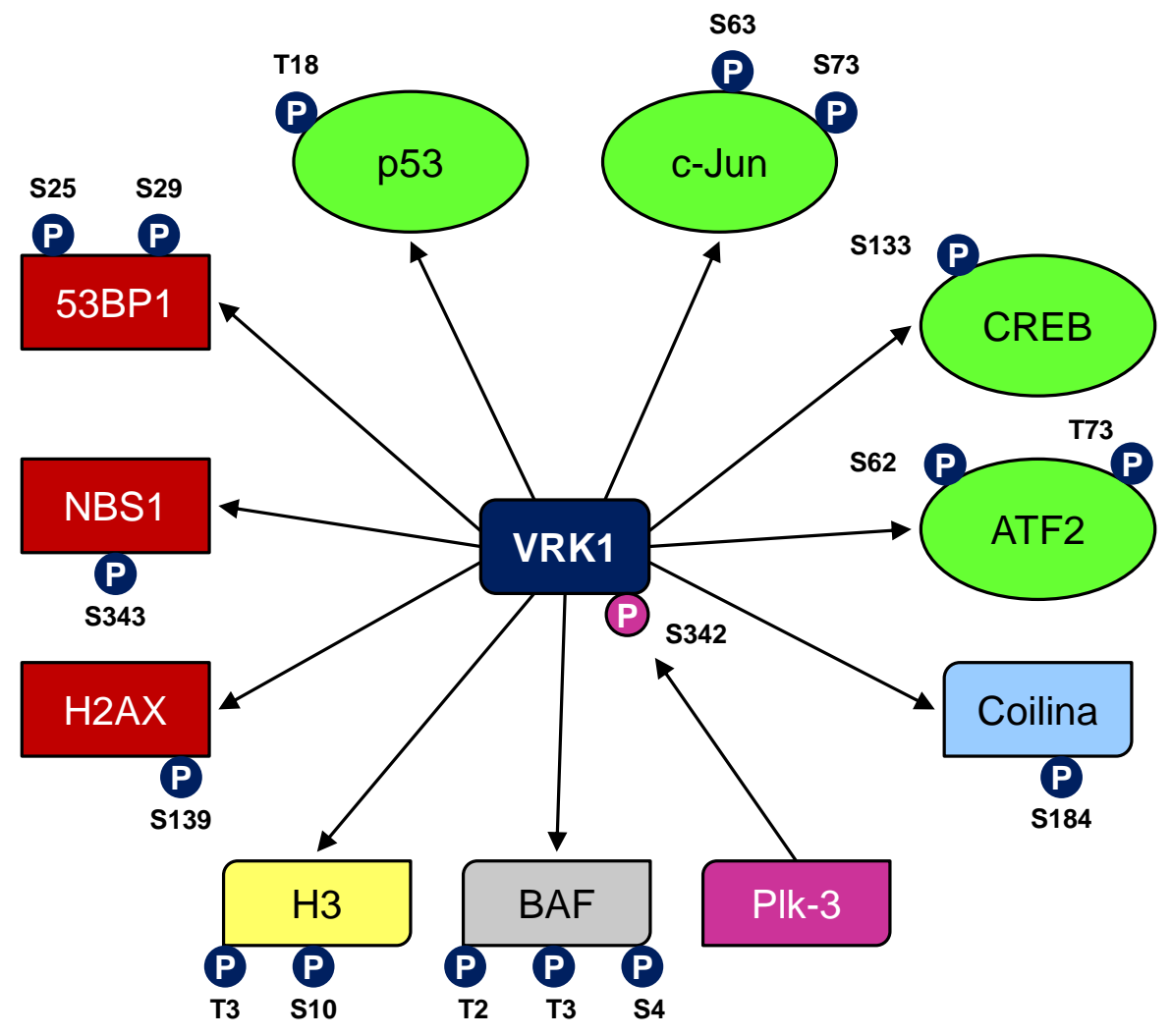

Figura 10: Principales sustratos de la quinasa humana VRK1, indicando los residuos fosforilados en cada caso.

\subsubsection{La quinasa VRK1 en la respuesta al daño génico}

Uno de los primeros eventos que tienen lugar cuando se produce alguna rotura en el ADN es la relajación local de la cromatina, de forma que las proteínas encargadas de la reparación puedan acceder más fácilmente a la región dañada. Estudios de silenciamiento de la quinasa humana VRK1 revelaron un cambio en el patrón basal de acetilación que, además, es independiente de ATM (85).

Tras la relajación de la cromatina, es necesario que la histona H2AX se fosforile en su serina 139 en la región próxima a las DSBs para favorecer el reclutamiento de otros 
mediadores de la respuesta y amplificar la señal de reparación. Como se ha mencionado en el apartado anterior, VRK1 es capaz de activarse en respuesta al daño génico inducido por radiación ionizante y mediar la fosforilación de la serina 139 de la histona $\operatorname{H2AX}(85)$.

Otro de los miembros de la cascada de señalización regulado por VRK1 es NBS1, que forma parte del complejo MRN. Esta quinasa forma un complejo basal con NBS1 y fosforila a esta proteína en la serina 343 en respuesta al daño génico inducido por radiación ionizante o doxorrubicina (Figura 10). Por esta razón, el número de focos de NBS1 se reduce drásticamente tras silenciar $V R K 1$ e inducir daño en el ADN. Además, la ausencia conjunta de VRK1 y ATM conlleva una bajada de los niveles de NBS1, que no se observa cuando ATM está presente y que se revierte utilizando inhibidores del proteasoma. Esto quiere decir que VRK1 fosforila y protege a NBS1 de su degradación vía proteasoma durante la DDR, siendo importante el papel de ATM en el mantenimiento de su estabilidad (86).

En la respuesta a las roturas de doble cadena mediada por unión de extremos no homólogos (NHEJ), especialmente importante en las células que no se dividen, es esencial la función de 53BP1 en el ensamblaje de otras proteínas reparadoras. En este contexto, la quinasa VRK1 se activa, interacciona y fosforila a 53BP1 en los residuos de serina 25 y 29 (Figura 10), que también son diana de ATM (94). Asimismo, la ausencia de VRK1 compromete la formación de focos de 53BP1 tras inducir daño génico con radiación ionizante, un efecto independiente de ATM y p53. Además, VRK1 es una proteína de respuesta temprana previa a la activación de ATM, ya que el silenciamiento de $V R K 1$ afecta a la formación de focos de $\mathrm{YH} 2 \mathrm{AX}$, pero no a la de MDC1, que es un evento posterior de la DDR y un sustrato conocido de ATM (101). Cabe destacar también que la disminución del número de focos de 53BP1 asociado a la ausencia de VRK1 es reproducible en líneas de cáncer de mama y en respuesta a distintos agentes causantes de roturas de doble cadena en el ADN (180).

Por último, es necesario mencionar el papel de p53 en la respuesta al daño, ya que media la activación transcripcional de genes implicados en parada de ciclo, esencial para evitar que el ADN dañado pueda transmitirse a las células hijas, o en apoptosis, cuando el daño génico es excesivo y no puede repararse convenientemente (181). Aparte de la fosforilación de p53 mediada por VRK1 y su loop de autorregulación, mencionados anteriormente, es importante resaltar que VRK1 y p53 forman un complejo basal capaz de activarse casi de manera inmediata en respuesta al daño inducido por luz ultravioleta (182). 


\subsubsection{Implicación de VRK1 en cáncer}

En base a las funciones de VRK1 en el contexto de la proliferación y la progresión del ciclo celular, sería de esperar que esta quinasa desempeñase un papel activo en la biología tumoral (151, 156-158). Mediante experimentos de supresión génica de VRK1 con el sistema CRISP/Cas9, se ha identificado a VRK1 como driver oncogénico (183), lo que es consistente con los estudios realizados en adenocarcinomas de pulmón en los que se habla de esta quinasa como una posible diana terapéutica por su implicación en el proceso de división celular (184). Además, la alteración de la respuesta al daño génico asociada al silenciamiento de VRK1 sensibiliza a las células tumorales a distintos agentes quimioterapéuticos (180).

A pesar de su papel oncogénico, puede decirse también, aunque parezca contradictorio, que VRK1 es un supresor tumoral. Esto es así debido a la regulación que esta quinasa ejerce sobre p53, que contribuye, de manera indirecta, al mantenimiento de la estabilidad genómica (185).

La quinasa VRK1 se expresa de manera diferencial en distintos tipos celulares, pero no se ha visto que esté mutada en cáncer. En algunos casos, se ha utilizado como marcador predictivo en pacientes de cáncer rectal que responden bien a la quimioterapia neoadyuvante (186). Sin embargo, la sobreexpresión de esta quinasa en mieloma múltiple (187) o en tumores de mama (188-191), pulmón (184), hígado (192, 193), glioblastoma / glioma (194, 195), cabeza y cuello (156), y esofágo (196, 197) implica un peor pronóstico.

\subsubsection{VRK1 y las enfermedades neurodegenerativas}

Mediante el uso de arrays peptídicos se indentificó a la coilina como nuevo sustrato de la quinasa humana VRK1. Esta proteína juega un papel fundamental en el ensamblaje de los cuerpos de Cajal y está implicada en varias enfermedades neurodegenerativas (198). Estudios posteriores demostraron que VRK1 forma un complejo intracelular con la coilina y la fosforila durante la mitosis en la serina 184 (Figura 10), un paso clave para la formación de los cuerpos de Cajal. Sin embargo, en ausencia de VRK1 o cuando esta quinasa no es activa, la coilina se ubiquitina y se dirige al citosol donde se degrada vía proteasoma (199). Aparte del papel que juega VRK1 en la formación de los cuerpos de Cajal, mutaciones en el gen que codifica esta quinasa están íntimamente relacionadas con patologías neurodegenerativas.

La primera mutación descubierta en el gen VRK1 fue la R358X (en homocigosis), que consistía en una transición C>T en el nucleótido 4 del exón 12. Dicha mutación 
modificaba la secuencia de localización nuclear de la proteína y generaba un codón de terminación prematuro que hacía que esta proteína fuese citosólica $(198,200)$. El fenotipo de estos pacientes, pertenecientes a una familia judía de etnia Ashkenazi, incluía microcefalia, ataxia muscular espinal con hipoplasia pontocerebelosa de tipo 1 , leve retraso mental y en el desarrollo, atrofia muscular y ataxia, que derivó en debilidad muscular severa y problemas respiratorios que condujeron a su muerte a edad temprana (200-202).

Otra de las mutaciones descritas fue la R133C, localizada en el dominio quinasa. Se describió a través de un estudio en el que se buscaban genes relacionados con trastornos cognitivos recesivos, y presentaba hipoplasia pontocerebelar como característica clínica (203). Por su parte, las mutaciones R89Q y V236M se encontraron en heterocigosis en dos hermanas que presentaban microcefalia, ataxia muscular espinal y neuropatía sensorio-motora axonal, y se manifestaron durante la niñez (201).
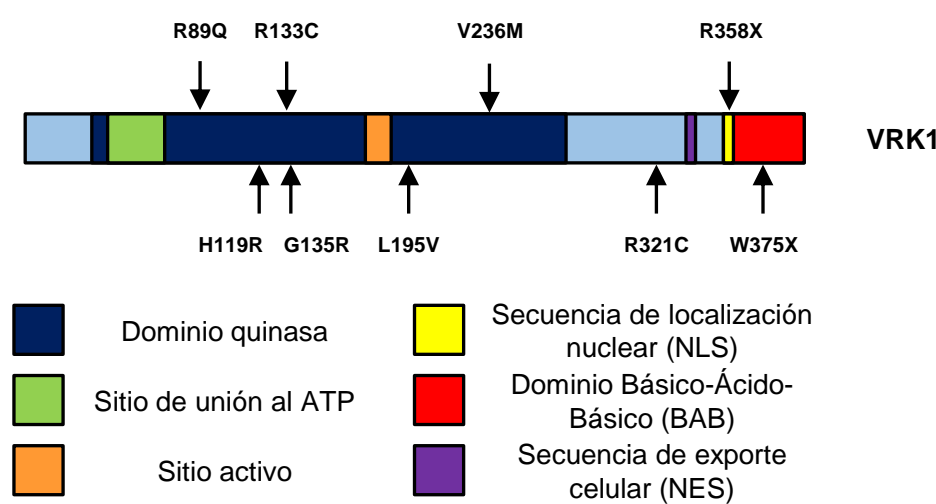

Secuencia de localización nuclear (NLS)

Dominio Básico-ÁcidoBásico (BAB)

Secuencia de exporte celular (NES)

Figura 11: Estructura de la quinasa humana VRK1 en la que aparecen señaladas las distintas mutaciones asociadas a procesos neurodegenerativos y su localización en la proteína.

Más tarde se descubrieron nuevas mutaciones en heterocigosis, en este caso, en un individuo adulto. Estas mutaciones son las H119R y R321C y se asociaron al desarrollo de esclerosis lateral amiotrófica en el paciente (204). También durante la etapa adulta se encontraron dos pacientes con las mutaciones H119R y R358X en heterocigosis que presentaban ataxia muscular espinal distal (205). A su vez, este mismo estudio reveló la presencia de otras dos mutaciones, G135R y L195V, de nuevo en heterocigosis, en un único individuo con esclerosis lateral amiotrófica juvenil, acompañada de atrofia muscular espinal distal y neuropatía sensorio-motora axonal (205). 
Por último, se ha descubierto una nueva mutación del gen VRK1, W375X, que apareció en homocigosis y que genera un codón de terminación prematuro, igual que la R358X. Los pacientes presentaban neuropatía sensorio-motora axonal y atrofia muscular espinal distal, manifestados durante la adolescencia (206).

Debido al elevado número de mutaciones en el gen $V R K 1$ que afectan a distintas regiones de la proteína, el estudio y caracterización de las mismas podría ayudar a entender un poco mejor las enfermedades neurodegenerativas en las que esta quinasa está implicada.

\subsubsection{Ratones knock-out para VRK1}

Estudios realizados con ratones hipomórficos para VRK1, que solamente expresan el $15 \%$ de la proteína en comparación con los silvestres, revelaron que estos animales son estériles, ya sean machos o hembras. Esto se debe, en el caso de los machos, a que la ausencia de VRK1, que se expresa en las células de Sertoli de los testículos y en la espermatogonia, conlleva un defecto progresivo en la proliferación y diferenciación de las células espermatogónicas que conduce a la ausencia total de mitosis y meiosis en el testículo adulto (207). Además, la pérdida de VRK1 interfiere también en el mantenimiento de la población de las células madre en la espermatogonia (208). En las hembras, la disminución de los niveles de expresión de VRK1 va acompañada de un retraso en la progresión meiótica durante la oogénesis, que, en última instancia, genera esterilidad total (209). A su vez, experimentos más recientes han demostrado que los ovarios carentes de VRK1 presentan defectos severos durante la foliculogénesis que afectan al crecimiento y a la calidad de los oocitos (210).

\subsubsection{Regulación de la quinasa VRK1}

Debido a la cantidad de funciones asociadas a la quinasa VRK1, es necesario que su actividad esté estrictamente regulada a través de diversos mecanismos. A nivel transcripcional, se sabe que la actividad de esta quinasa está controlada por factores mitogénicos presentes en el suero, que promueven la transición G0/G1 del ciclo celular (157), pero, además, diversos factores de transcripción participan en la activación de VRK1 en respuesta a señales proliferativas, como es el caso de E2F1 (156) y Myc (171).

Más recientemente se ha visto que el factor de transcipción aberrante EWS-FLI1, asociado al sarcoma de Ewing, altera el patrón de expresión génica de este tipo de 
cáncer, reprimiendo supresores tumorales y activando oncogenes y nuevas dianas terapéuticas potenciales, como es el caso de VRK1 (211).

Mención aparte merece la relación entre Sox2 y VRK1. Sox2 es uno de los "factores de Yamanaka", esenciales en reprogramación celular (212), que también participa en la autorrenovación de las células madre, en proliferación y en procesos de diferenciación celular. Se ha descrito que VRK1 y Sox2 muestran un patrón de localización similar en epitelio escamoso y que forman un complejo estable. Además, Sox2 regula la expresión de VRK1 y juntos cooperan en la activación del gen CCND1. Sin embargo, existe un loop de autorregulación entre Sox2 y VRK1, por el que esta quinasa también modula la expresión de este factor de transcripción. Finalmente, cabe resaltar que los niveles de Sox2 y VRK1 se reducen significativamente a medida que las células inician su programa de diferenciación (213).

También es importante destacar el papel de las macrohistonas en este contexto de activación/represión transcripcional. La macrohistona H2A1.2 es una variante de la histona $\mathrm{H} 2 \mathrm{~A}$ con un dominio C-terminal más grande, denominado macrodominio, y cuya expresión se asocia generalmente a represión transcripcional. Esta macrohistona interacciona con VRK1 a través de su región C-terminal durante la interfase e impide que esta quinasa fosforile a la histona $\mathrm{H} 3$ durante esa etapa del ciclo celular (214). A su vez, se ha visto que las macrohistonas H2A1.2 y H2A.2 inhiben la expresión de los genes que codifican para VRK1, Sox2 y ciclina D1, implicados en proliferación, durante la diferenciación celular (213).

La autofosforilación de VRK1 también tiene un importante papel regulador que, a su vez, potencia su actividad catalítica y su estabilidad $(136,147,157)$. Uno de los residuos que se autofosforilan, la serina 355 (165), se fosforila también en respuesta al daño en el $A D N$ vía la proteína quinasa $C \delta$ (PKCঠ). Esta fosforilación regula negativamente la actividad quinasa de VRK1 y promueve la muerte celular dependiente de p53 (215).

Como se ha mencionado en apartados anteriores, VRK1 también se activa en respuesta a radiación ionizante y otros agentes quimioterapéuticos, poniendo en marcha los mecanismos de respuesta al daño en el $\operatorname{ADN}(85,86,101,180,182)$.

Otro de los mecanismos por los que se regula la actividad de VRK1 es la interacción con otras proteínas. Estudios proteómicos identificaron a la GTPasa Ran entre las proteínas candidatas para regular las quinasas VRK. Se vio que esta GTPasa era capaz de interaccionar de forma estable con los tres miembros de la familia, 
independientemente de que estuviese unida a GTP o GDP. Sin embargo, la interacción entre Ran-GDP y cualquiera de estas quinasas regulaba negativamente su capacidad de autofosforilación y fosforilación de sustratos (216).

Finalmente, se ha estudiado también la posibilidad de utilizar inhibidores específicos frente a esta quinasa, ya que los dirigidos frente a otras familias de quinasas no muestran efectos significativos sobre la autofosforilación de VRK1 y la fosforilación de sustratos como p53 o H3 (217). Dichos inhibidores, luteolina y ácido ursólico, son capaces de interaccionar con VRK1 e inhibir su actividad quinasa, pero requieren dosis muy altas para su funcionamiento, con el consecuente aumento de la toxicidad y de los posibles efectos secundarios $(218,219)$. 



\section{Objetivos}

1. Caracterizar la implicación de la quinasa humana VRK1 en la respuesta al daño génico causado por la combinación del fármaco quimioterapéutico olaparib y la radiación ionizante.

2. Estudiar la regulación del ciclo celular y la reparación de las roturas de doble cadena en el ADN asociadas al tratamiento con el inhibidor de metiltransferasas chaetocin.

3. Analizar el papel de la quinasa de la cromatina VRK1 en el patrón basal de acetilación y metilación de las histonas H3 y H4. 



\section{Materiales y}

métodos 



\section{TÉCNICAS DE MANIPULACIÓN DE PROTEÍNAS}

\subsection{Obtención de extractos proteicos de células en cultivo}

Para obtener extractos proteicos totales, se lisaron las células en cultivo con tampón de lisis suave $(50 \mathrm{mM}$ de Tris- $\mathrm{HCl}, \mathrm{pH} 8.0,150 \mathrm{mM}$ de $\mathrm{NaCl}$, Tritón X-100 al 1\% y 1 $\mathrm{mM}$ de EDTA) o RIPA ( $150 \mathrm{mM}$ de $\mathrm{NaCl}, 1,5 \mathrm{mM}$ de $\mathrm{MgCl}_{2}, 10 \mathrm{mM}$ de $\mathrm{NaF}, 4 \mathrm{mM}$ de EDTA, $50 \mathrm{mM}$ de Hepes, Tritón X-100 al 1\%, SDS al 0,1\% y glicerol al 10\%), en función de la línea celular. A su vez, ambos tampones se suplementaron con inhibidores de proteasas ( $1 \mathrm{mM}$ de PMSF, $10 \mu \mathrm{g} / \mathrm{ml}$ de aprotinina y $10 \mu \mathrm{g} / \mathrm{ml}$ de leupeptina) y fosfatasas ( $1 \mathrm{mM}$ de ortovanadato de sodio y $1 \mathrm{mM}$ de $\mathrm{NaF}$ ) antes de iniciar la lisis. Tras incubar los extractos celulares obtenidos durante 20 minutos en hielo, se centrifugaron a $13.200 \mathrm{rpm}$ a $4^{\circ} \mathrm{C}$ durante 20 minutos y se recuperó la fracción soluble, mientras que el precipitado restante fue descartado.

\section{$1.2 \quad$ Extracción ácida de histonas}

Con el objetivo de analizar las variaciones en las modificaciones covalentes de las histonas que forman parte del nucleosoma, se puso en práctica el protocolo de extracción ácida de histonas (220). Tras los experimentos correspondientes, se recogieron las células por centrifugación (10 minutos, $300 \mathrm{~g}$ ), se lavaron con $10 \mathrm{ml}$ de PBS $1 \mathrm{X}$ y se centrifugaron de nuevo (10 minutos, $300 \mathrm{~g})$, descartando el sobrenadante. A continuación, se resuspendió el precipitado celular en $1 \mathrm{ml}$ de tampón de lisis hipotónico (10 mM de Tris- $\mathrm{HCl} \mathrm{pH} 8,1 \mathrm{mM}$ de $\mathrm{KCl}, 1,5 \mathrm{mM}$ de $\mathrm{MgCl}_{2}$ y $1 \mathrm{mM}$ de DTT), suplementado con inhibidores de proteasas ( $1 \mathrm{mM}$ de PMSF, $10 \mu \mathrm{g} / \mathrm{ml}$ de aprotinina y $10 \mu \mathrm{g} / \mathrm{ml}$ de leupeptina) durante 30 minutos en la noria, para favorecer la lisis tanto hipotónica como mecánica, y se pasó la solución a un tubo de 1,5 ml. Desde este punto hasta finalizar el protocolo, los distintos pasos se realizaron a $4^{\circ} \mathrm{C}$. Seguidamente se precipitaron los núcleos intactos por centrifugación (10 minutos, $10.000 \mathrm{~g})$ y se eliminó el sobrenadante con la pipeta. A continuación, se resuspendieron los núcleos resultantes con $400 \mu \mathrm{l}$ de ácido sulfúrico $0,4 \mathrm{~N}$ hasta que la solución fuese completamente homogénea, utilizando el vórtex si fuera preciso, y se incubó dicha solución durante, al menos, 30 minutos o toda la noche en la noria. Pasado este tiempo, se precipitaron los debris nucleares por centrifugación (10 minutos, $16.000 \mathrm{~g}$ ) y el sobrenadante, que contiene las histonas, se pasó a un nuevo tubo de 1,5 ml. En este punto, se utilizó ácido tricloroacético a una concentración final del $33 \%$ para precipitar las histonas, y la mezcla resultante, de aspecto lechoso, se incubó en hielo durante 30 minutos o toda la noche. El siguiente paso fue centrifugar 
la mezcla para que sedimentasen las histonas (10 minutos, $16.000 \mathrm{~g}$ ). Posteriormente se retiró con mucho cuidado el sobrenadante y se lavaron 2 veces las histonas con acetona fría, sin resuspenderlas, para eliminar el ácido residual todavía presente en la solución. Finalmente, se eliminó el sobrenadante con la pipeta, se dejó secar el precipitado de histonas durante 20 minutos a temperatura ambiente $y$, pasado ese tiempo, se resuspendieron las histonas en 100-120 $\mu$ le agua milliQ para cuantificarlas a continuación y analizarlas por western blot.

\subsection{Cuantificación de proteínas}

Una vez obtenidos los extractos proteicos totales o los enriquecidos en histonas, se cuantificaron utilizando el método de Bradford, que se basa en el empleo del azul brillante G-250 Coomassie, un colorante que, al unirse a las proteínas de la muestra, vira de un color pardo a uno rojo-azulado y altera su máximo de absorción (de $465 \mathrm{~nm}$ a $595 \mathrm{~nm}$ ). Se utilizó el reactivo comercial Bio-Rad Protein Assay (Bio-Rad) y se realizó una curva patrón usando concentraciones conocidas de albúmina sérica bovina (BSA, bovine serum albumin). Una vez cuantificados, se prepararon extractos proteicos con la misma cantidad de proteína total, se les añadió tampón de carga (62,5 mM de Tris-HCl pH 6,8, glicerol al 10\%, SDS al 2,3\%, azul de bromofenol al $0,1 \%$ y $\beta$-mercaptoetanol al $5 \%$ ) y se hirvieron durante 5 minutos a $100{ }^{\circ} \mathrm{C}$.

\subsection{Electroforesis en geles SDS-PAGE}

Las proteínas se separaron en función de su tamaño mediante electroforesis vertical en geles SDS-PAGE (sodium dodecylsulfate - polyacrilamide gel electrophoresis). EI SDS (dodecilsulfato sódico) es un detergente aniónico que desnaturaliza y se une a las proteínas, confiriéndoles una carga negativa uniforme debido a sus grupos sulfato. De esta forma, la propia carga de la proteína queda enmascarada por las múltiples moléculas de SDS y se alcanza una relación carga:masa uniforme. Así, todas las proteínas migran de igual manera hacia el polo positivo en función de su masa molecular.

Para la separación de proteínas de distinto tamaño se realizaron geles separadores (resolving) con concentraciones variables de acrilamida y bis-acrilamida (7,5-12,5\% y 0,2-0,33\%, respectivamente) en un tampón de $0,375 \mathrm{M}$ de Tris- $\mathrm{HCl} \mathrm{pH} 8,8$ y 3,5 mM de SDS, en función de la/s proteína/s que se quisieran analizar: 
Proteínas <25-30 kDa: 12,5\% acrilamida - 0,33\% bis-acrilamida.

Proteínas de 30-150 kDa: 10\% acrilamida - 0,27\% bis-acrilamida.

Proteínas $>150 \mathrm{kDa}: 7,5 \%$ acrilamida $-0,2 \%$ bis-acrilamida.

Encima de este gel separador se preparó el gel concentrador (stacking), compuesto por acrilamida al 4,8\% y bis-acrilamida al 0,128\% en tampón Tris-HCl pH 6,8 a 0,125 M y 3,5 mM de SDS. Para la solidificación de ambos tipos de geles, se añadió un agente iniciador de la polimerización, el persulfato de amonio (APS, ammonium persulfate) y un catalizador de la formación de radicales libres, el TEMED $(\mathrm{N}, \mathrm{N}, \mathrm{N}$ ', N'- tetrametiletilenodiamina).

El gel se corrió en condiciones desnaturalizantes en tampón de carrera $(25 \mathrm{mM}$ de Tris- $\mathrm{HCl}, 200 \mathrm{mM}$ de glicina y 1,7 mM de SDS) y se utilizaron marcadores de peso molecular preteñidos Precision Plus Protein ${ }^{T M}$ Standards Dual Color (Bio-Rad).

\subsection{Transferencia húmeda y western blot}

Después de la electroforesis, las proteínas se transfirieron a membranas ImmobilonFL (Millipore) mediante transferencia húmeda (221) para su posterior detección con anticuerpos específicos. El tampón de transferencia utilizado estaba formado por Tris$\mathrm{HCl}$ a $25 \mathrm{mM}, 19,2 \mathrm{mM}$ de glicina y metanol al 10-20\%, en el que la concentración de metanol varía según el peso molecular de las proteínas de interés (a menor tamaño de la proteína, mayor concentración de metanol). La transferencia se realizó durante 1-1,5 horas a $80-90 \mathrm{~V}$ o durante toda la noche a $40 \mathrm{~V}$.

Para llevar a cabo el western blot, la membrana de transferencia se bloqueó durante 1 hora a temperatura ambiente o toda la noche a $4^{\circ} \mathrm{C}$ en agitación en leche en polvo desnatada o BSA al 5\%, resuspendidos en el tampón TBS-T (25 mM de Tris- $\mathrm{HCl}$ pH $8,50 \mathrm{mM}$ de $\mathrm{NaCl}, 2,5 \mathrm{mM}$ de $\mathrm{KCl}$ y Tween-20 al 0,1\%). A continuación, la membrana se incubó con el anticuerpo primario necesario (ver tabla 6) para detectar la proteína de interés a la dilución correspondiente en TBS-T, o en leche o BSA al 5\% en TBS-T, según las recomendaciones del fabricante, durante 1-2 horas a temperatura ambiente o toda la noche a $4^{\circ} \mathrm{C}$. Después de la incubación, se realizaron 3 lavados durante 10 minutos cada uno con TBS-T en agitación, y se incubó la membrana con los anticuerpos secundarios conjugados a distintos fluorocromos en función de su reactividad durante 1 hora a una dilución 1:10.000 en oscuridad y, tras 3 lavados de 10 minutos con TBS-T, la membrana se reveló en el LI-COR Odyssey Infrared Imaging System, que detecta la fluorescencia emitida por los anticuerpos secundarios, 
que reconocen la fracción constante de los anticuerpos específicos de las proteínas a estudiar en cada caso. Posteriormente, se utilizó el software ImageJ para cuantificar la intensidad de las bandas obtenidas como se especifica en experimentos concretos.

\section{MANEJO DE LÍNEAS CELULARES EN CULTIVO}

\subsection{Cultivo de líneas celulares}

Las líneas celulares y los medios de cultivo usados para su correcto crecimiento se especifican en la tabla 3. Estas líneas se cultivaron en monocapa en frascos de cultivo (Flasks, $B D$ Falcon) a $37^{\circ} \mathrm{C}, 5 \%$ de $\mathrm{CO}_{2}$ y $98 \%$ de humedad relativa. Los medios de cultivo (DMEM, RPMI; Sigma-Aldrich) se suplementaron con 10\% de FBS (suero fetal bovino), $2 \mathrm{mM}$ de L-glutamina, y los antibióticos penicilina (50 unidades $/ \mathrm{ml}$ ) y estreptomicina $(50 \mu \mathrm{g} / \mathrm{ml})$, obtenidos de GIBCO-life technologies. Para levantar las células de los frascos se utilizó una solución de tripsina-EDTA (TryplE ${ }^{T M}$, Thermo Fisher Scientific) y para observar las líneas celulares se empleó un microscopio óptico invertido Zeiss Axiovert 25.

\begin{tabular}{|c|c|c|c|c|}
\hline $\begin{array}{c}\text { Línea } \\
\text { celular }\end{array}$ & Organismo & Procedencia & Características & $\begin{array}{c}\text { Medio de } \\
\text { cultivo }\end{array}$ \\
\hline A549 & Humano & $\begin{array}{r}\text { Adenocarcinoma de } \\
\text { pulmón } \\
\text { Carcinoma de } \\
\text { pulmón }\end{array}$ & $\begin{array}{c}\text { Deficientes de } \\
\text { p53 }\end{array}$ & DMEM \\
\hline H1299 & Humano & Melanoma & $\begin{array}{c}\text { Deficientes de } \\
\text { ATM }\end{array}$ & DMEM \\
\hline HT144 & Humano & Carcinoma de & Subtipo basal B & DMEM \\
\hline MDA-MB- & Humano & mama & - & DMEM \\
\hline U231 & Humano & Osteosarcoma & & \\
\hline
\end{tabular}

Tabla 3: Descripción y principales características de las líneas celulares utilizadas. 


\subsection{Supresión de la expresión génica mediante ARNi. Transfección con Lipofectamine o Lipotransfectine}

Para silenciar la expresión del gen VRK1 se usaron los dúplex de ARN de interferencia (ARNi) especificados en la tabla 4 de la casa comercial Dharmacon RNA Technologies. Como control negativo se empleó un dúplex de ARN carente de diana en las células humanas, ON-TARGETplus Non-targeting siRNA, de la misma casa comercial.

Estos experimentos de supresión génica se llevaron a cabo con los reactivos Lipofectamine $^{T M} 2000$ (Invitrogen) o Lipotransfectine (Solmeglass), con el fin de conseguir mayor eficiencia de transfección de los oligonucleótidos. Ambos reactivos contienen subunidades lipídicas que pueden formar liposomas de naturaleza catiónica en ambientes acuosos, capaces de formar complejos con los ácidos nucleicos (cargados negativamente). De esta forma, se evita la repulsión electrostática de la membrana celular (también de carga negativa) y se facilita la fusión de estos complejos con dicha membrana, lo que permite su posterior incorporación a la célula. En este caso, las cantidades correspondientes de los reactivos Lipofectamine o Lipotransfectine se diluyeron en un volumen de Opti-MEM (GIBCO-life technologies) $y$, tras 5-10 minutos de incubación, se añadieron a un volumen de Opti-MEM en el que previamente se habían resuspendido los ARN de interferencia a una concentración de $200 \mathrm{nM}$. Transcurridos 30 minutos, se añadieron las mezclas sobre las células cultivadas en medio sin antibiótico, dado que estas células podrían incorporarlos junto con los ARNi, lo que comprometería seriamente su viabilidad.

\begin{tabular}{|c|c|c|}
\hline $\begin{array}{c}\text { Denominación } \\
\text { siCtrl (ON-TARGETplus } \\
\text { Non-targeting siRNA) }\end{array}$ & UGGUUUACAUGUCGACUAA & $\begin{array}{r}\text { Control negativo de } \\
\text { silenciamiento }\end{array}$ \\
\hline siVRK1-02 & CAAGGAACCUGGUGUUGAA & $\begin{array}{r}\text { Silenciamiento de la } \\
\text { quinasa VRK1 }\end{array}$ \\
\hline siVRK1-03 & GGAAUGGAAAGUAGGAUUA & $\begin{array}{r}\text { Silenciamiento de la } \\
\text { quinasa VRK1 }\end{array}$ \\
\hline
\end{tabular}

Tabla 4: Secuencias y uso de los oligonucleótidos empleados. 


\section{LOCALIZACIÓN SUBCELULAR DE PROTEÍNAS}

\subsection{Inmunofluorescencia y microscopía confocal}

Los ensayos de inmunofluorescencia se emplearon para estudiar los cambios de localización subcelular de proteínas endógenas. En estos ensayos, se sembraron las células sobre cubreobjetos de vidrio, que, en ocasiones, se trataron con poli-L-lisina (Sigma-Aldrich) al 0,01\% para mejorar la adhesión celular al cristal. Finalizado el experimento, se lavaron las células con PBS $1 \mathrm{X}$ y se fijaron con paraformaldehído al $3 \%$ en PBS $1 \mathrm{X}$ durante 30 minutos a temperatura ambiente. Seguidamente se les añadió glicina $(200 \mathrm{mM})$ durante 15 minutos, también a temperatura ambiente, para reducir la toxicidad asociada a los grupos aldehídos libres tras la fijación. Posteriormente, se permeabilizaron con Tritón X-100 al 0,2\% en PBS 1X durante 30 minutos, y finalmente, se utilizó como solución de bloqueo BSA al 1\% en PBS $1 \mathrm{X}$ con azida sódica (agente bacteriostático; dilución 1:1000 a partir de una solución madre al $10 \%$ ) durante 1 hora a temperatura ambiente o durante toda la noche a $4^{\circ} \mathrm{C}$.

Para la detección de dos proteínas a la vez, se incubaron los anticuerpos primarios de manera secuencial (ver tabla 6), diluidos en BSA al $1 \%$ con azida sódica a la concentración adecuada y se incubó durante 6-8 horas a temperatura ambiente 0 durante toda la noche a $4^{\circ} \mathrm{C}$, siguiendo las recomendaciones de la hoja técnica de cada anticuerpo. Entre el primer y el segundo anticuerpo primario, las células se lavaron tres veces con PBS 1X. Tras la incubación con el segundo anticuerpo primario, se realizaron tres lavados con PBS $1 \mathrm{X}$ para eliminar los restos de anticuerpo libre y las células se incubaron durante 1 hora a temperatura ambiente con los anticuerpos secundarios marcados con los fluorocromos de cianina Cy2 o Cy3, que se diluyeron 10.000 veces en BSA al $1 \%$ en PBS $1 \mathrm{X}$. Dado que los anticuerpos secundarios utilizados son fotosensibles, todas las etapas restantes se llevaron a cabo en oscuridad. Para eliminar el exceso de anticuerpos secundarios, las células se lavaron de nuevo 3 veces con PBS 1X y, a continuación, se tiñeron los núcleos celulares con DAPI (4', 6'-diamidino-2-fenilindol; Roche) a una concentración de 1 $\mu \mathrm{g} / \mathrm{ml}$ en PBS $1 \mathrm{X}$ durante 15 minutos a temperatura ambiente. Por último, se lavaron 3 veces los cubreojetos con PBS $1 \mathrm{X}$ y se montaron sobre los portaobjetos con MOWIOL $\circledast 4$-88 (Calbiochem). Finalizado el montaje, las imágenes con marcaje fluorescente se realizaron con el microscopio confocal Leica TCS SP5, que utiliza láseres de argón (488 nm), DPSS (561 nm) y UV (405 nm). En todos los experimentos llevados a cabo se mantuvieron constantes la intensidad y la ganancia de dichos láseres, y la compensación de los fotomultiplicadores, de forma que se pudiesen 
comparar las fotos correspondientes al control y a las muestras a estudiar en cada caso.

El número de focos y la fluorescencia de las distintas proteínas evaluadas en esta tesis se representaron en forma de box plot, donde la caja representa los valores que van del primer al tercer cuartil, la línea central es la mediana y los extremos se extienden hasta las observaciónes mínima y máxima, respectivamente. Para la cuantificación de estos focos o de la fluorescencia, relativizada con respecto al área celular, se utilizó el software ImageJ y, en cada experimento, se indica el test específico con el que se calculó la significación estadística.

\section{VIABILIDAD Y CICLO CELULAR}

\subsection{Citometría de flujo}

Para estudiar la viabilidad y los cambios en el perfil de ciclo celular, se recogieron las células por centrifugación (5 minutos, 1200 rpm) y se lavaron con PBS 1X. A continuación, se resuspendieron en $1 \mathrm{ml}$ de PBS $1 \mathrm{X}$ y se dividieron a partes iguales en dos tubos de citómetro, uno para estudiar la viabilidad y el otro, para estudiar los cambios en el perfil de ciclo celular. En el caso de la viabilidad, se añadió ioduro de propidio (50 $\mathrm{\mu g} / \mathrm{ml}$; Sigma-Aldrich) a los tubos correspondientes y se incubaron durante 5 minutos en oscuridad antes de analizar las muestras por citometría de flujo (Accuri C6, BD). Para el análisis de ciclo celular, se centrifugaron las células para eliminar el PBS 1X (5 minutos, 1200 rpm) y se fijaron con etanol frío al $70 \%$ durante toda la noche. Pasado este tiempo, se centrifugaron de nuevo para eliminar los restos de etanol (5 minutos, $1200 \mathrm{rpm}$ ) y se incubaron durante 1 hora con ioduro de propidio y ARNasa (ambos a $50 \mathrm{\mu g} / \mathrm{ml}$; Sigma-Aldrich) en oscuridad y agitación, para, finalmente, estudiar los cambios en el perfil de ciclo celular por citometría de flujo (Accuri C6, BD).

\section{REACTIVOS Y ESTIMULACIONES}

\subsection{Inducción de daño génico}

Para inducir daño en el ADN, se emplearon diferentes dosis (0,5-1-3 Gy) de radiación ionizante usando el irradiador Gammacell 1000 Elite con fuente de ${ }^{137} \mathrm{Cs}$, que emite radiación gamma de $\mathrm{E}=662 \mathrm{KeV}$, y distintas concentraciones de olaparib (2,5-5-10 $\mu \mathrm{M}$; LC Laboratories), un agente quimioterapéutico ampliamente utilizado en clínica. 


\subsection{Inhibición de proteínas}

En este trabajo se utilizó el inhibidor KU55933 frente a la quinasa ATM ( $1 \mu \mathrm{M}$; Tocris Bioscience), con el fin de mimetizar su ausencia en el cultivo celular.

También se emplearon inhibidores dirigidos frente a modificadores de histonas específicos, que aparecen detallados en la tabla 5 :

\begin{tabular}{|c|c|c|c|}
\hline Inhibidor & Diana & $\begin{array}{l}\text { Condiciones de } \\
\text { uso (disueltos en } \\
\text { DMSO) }\end{array}$ & $\begin{array}{c}\text { Casa } \\
\text { comercial }\end{array}$ \\
\hline Entinostat (MS-275) & $\begin{array}{l}\text { Familias de } \\
\text { HDACs } 1 \text { y } 3\end{array}$ & $5 \mu \mathrm{M} ; 24 \mathrm{~h}$ & Selleckchem \\
\hline $\begin{array}{c}\text { SAHA (suberoylanilide } \\
\text { hydroxamic acid o } \\
\text { Vorinostat) }\end{array}$ & $\begin{array}{c}\text { Pan-inhibidor de } \\
\text { HDACs }\end{array}$ & $5 \mu \mathrm{M} ; 24 \mathrm{~h}$ & $\begin{array}{l}\text { Sigma-Aldrich } \\
\text { (Merck) }\end{array}$ \\
\hline C646 & $\begin{array}{c}\text { HATs } \\
(p 300 / C B P)\end{array}$ & $5 \mu \mathrm{M} ; 24 \mathrm{~h}$ & Selleckchem \\
\hline $\begin{array}{l}\text { MG149 (análogo del } \\
\text { ácido anacárdico) }\end{array}$ & $\begin{array}{l}\text { Familia MYST } \\
\text { (Tip60 y MOZ) } \\
\text { de HATs }\end{array}$ & $1 \mu \mathrm{M} ; 24 \mathrm{~h}$ & Axon Medchem \\
\hline Chaetocin & KMTs & 100 nM; 24 h & $\begin{array}{c}\text { Santa Cruz } \\
\text { Biotechnology }\end{array}$ \\
\hline $\begin{array}{l}\text { JMJD2 inhibitor } \\
\text { (JMJD2i) }\end{array}$ & $\begin{array}{l}\text { Familia de } \\
\text { demetilasas } \\
\text { JMJD2 }\end{array}$ & $100 \mu \mathrm{M} ; 24 \mathrm{~h}$ & $\begin{array}{c}\text { Calbiochem } \\
\text { (Millipore) }\end{array}$ \\
\hline
\end{tabular}

Tabla 5: Inhibidores de los distintos modificadores de histonas utilizados, señalando las dianas para las que fueron diseñados y las formas de uso de cada uno de ellos.

\subsection{Sincronización celular}

Antes de estudiar las variaciones del ciclo celular por citometría de flujo, y con el fin de obtener resultados más reproducibles, las células se trataron con nocodazol (100 $\mathrm{ng} / \mathrm{ml}=0,33 \mu \mathrm{M}$; Sigma-Aldrich) durante toda la noche. Este compuesto sintético se une a los dímeros de tubulina libres e impide la polimerización de los microtúbulos (222). De esta forma, las células quedan bloqueadas en la fase G2/M del ciclo celular hasta que este compuesto se elimina del medio de cultivo. 


\begin{tabular}{|c|c|c|c|c|}
\hline Anticuerpo & Tipo & $\begin{array}{l}\text { Dilución } \\
\text { (WB/IF) }\end{array}$ & $\begin{array}{l}\text { Clon y/o } \\
\text { referencia }\end{array}$ & Casa comercial \\
\hline 53BP1 & $\begin{array}{l}\text { Policlonal de } \\
\text { conejo }\end{array}$ & $-; 1 / 200$ & $\begin{array}{c}\mathrm{H} 300, \mathrm{sc}- \\
22760\end{array}$ & $\begin{array}{c}\text { Santa Cruz } \\
\text { Biotechnology }\end{array}$ \\
\hline 53BP1 & $\begin{array}{l}\text { Policlonal de } \\
\text { conejo }\end{array}$ & $\begin{array}{l}1 / 500 \\
1 / 200\end{array}$ & NB100-304 & Novus Biologicals \\
\hline NBS1 & $\begin{array}{l}\text { Monoclonal de } \\
\text { ratón }\end{array}$ & $-; 1 / 200$ & 611871 & BD Biosciences \\
\hline NBS1 (nibrin) & $\begin{array}{l}\text { Policlonal de } \\
\text { conejo }\end{array}$ & 1/1000; - & N 3162 & Sigma-Aldrich \\
\hline MDC1 & $\begin{array}{l}\text { Policlonal de } \\
\text { conejo }\end{array}$ & $\begin{array}{l}1 / 500 \\
1 / 200\end{array}$ & ab11169 & Abcam \\
\hline VRK1 & $\begin{array}{l}\text { Monoclonal de } \\
\text { ratón }\end{array}$ & $\begin{array}{l}1 / 1000 \\
1 / 200\end{array}$ & 1B5 & $\begin{array}{c}\text { Producción propia } \\
\qquad(153)\end{array}$ \\
\hline VRK1 & $\begin{array}{l}\text { Policlonal de } \\
\text { conejo }\end{array}$ & 1/1000;- & VC & $\begin{array}{c}\text { Producción propia } \\
\qquad(153)\end{array}$ \\
\hline $\begin{array}{l}\text { VRK1 }(\mathrm{N}- \\
\text { term })\end{array}$ & $\begin{array}{l}\text { Policlonal de } \\
\text { conejo }\end{array}$ & $-; 1 / 200$ & HPA000660 & Sigma-Aldrich \\
\hline$\beta$-actina & $\begin{array}{l}\text { Monoclonal de } \\
\text { ratón }\end{array}$ & 1/2000; - & AC15, A5441 & Sigma-Aldrich \\
\hline $\mathrm{yH} 2 \mathrm{AX}$ & $\begin{array}{l}\text { Monoclonal de } \\
\text { ratón }\end{array}$ & $-; 1 / 200$ & $\begin{array}{c}\text { JBW301; 05- } \\
636\end{array}$ & Millipore \\
\hline $\begin{array}{l}\text { Goat anti- } \\
\text { mouse lgG } \\
\quad(\mathrm{WB})\end{array}$ & $\begin{array}{c}\text { Cabra anti-ratón } \\
\text { IgG, DyLight } 680 \\
\text { (rojo) }\end{array}$ & 1/10000; - & 35518 & $\begin{array}{c}\text { Thermo Fisher } \\
\text { Scientific }\end{array}$ \\
\hline $\begin{array}{l}\text { Goat anti- } \\
\text { rabbit IgG } \\
\text { (WB) }\end{array}$ & $\begin{array}{l}\text { Cabra-anti- } \\
\text { conejo IgG, } \\
\text { DyLight } 800 \\
\text { (verde) }\end{array}$ & 1/10000; - & 35571 & $\begin{array}{c}\text { Thermo Fisher } \\
\text { Scientific }\end{array}$ \\
\hline $\begin{array}{l}\text { Goat anti- } \\
\text { mouse lgG } \\
\quad \text { (IF) }\end{array}$ & $\begin{array}{c}\text { Cabra anti-ratón } \\
\text { IgG unido a Cy3 } \\
\text { (rojo) }\end{array}$ & $-; 1 / 1000$ & $115-165-146$ & $\begin{array}{c}\text { Jackson } \\
\text { ImmunoResearch }\end{array}$ \\
\hline $\begin{array}{c}\text { Goat anti- } \\
\text { rabbit lgG (IF) }\end{array}$ & $\begin{array}{c}\text { Cabra-anti- } \\
\text { conejo IgG unido } \\
\text { a Cy2 (verde) }\end{array}$ & $-; 1 / 1000$ & $111-225-144$ & $\begin{array}{c}\text { Jackson } \\
\text { ImmunoResearch }\end{array}$ \\
\hline
\end{tabular}




\begin{tabular}{|c|c|c|c|c|}
\hline Anticuerpo & Tipo & $\begin{array}{l}\text { Dilución } \\
\text { (WB/IF) }\end{array}$ & $\begin{array}{l}\text { Clon y/o } \\
\text { referencia }\end{array}$ & Casa comercial \\
\hline Histona H3 & $\begin{array}{l}\text { Policlonal de } \\
\text { conejo }\end{array}$ & 1/1000; - & 9715 & Cell Signaling \\
\hline $\begin{array}{c}\text { Trimetil- } \\
\text { histona H3 } \\
\text { (Lys4) }\end{array}$ & $\begin{array}{l}\text { Policlonal de } \\
\text { conejo }\end{array}$ & $\begin{array}{l}1 / 500 \\
1 / 400\end{array}$ & 9727 & Cell Signaling \\
\hline $\begin{array}{c}\text { Acetil-histona } \\
\text { H3 (Lys9) }\end{array}$ & $\begin{array}{l}\text { Policlonal de } \\
\text { conejo }\end{array}$ & $\begin{array}{c}1 / 2000 \\
1 / 400\end{array}$ & $07-352$ & Millipore \\
\hline $\begin{array}{c}\text { Trimetil- } \\
\text { histona H3 } \\
\text { (Lys9) }\end{array}$ & $\begin{array}{l}\text { Policlonal de } \\
\text { conejo }\end{array}$ & $\begin{array}{l}1 / 500 \\
1 / 200\end{array}$ & $07-442$ & Millipore \\
\hline $\begin{array}{c}\text { Acetil-histona } \\
\text { H4 (Lys16) }\end{array}$ & $\begin{array}{l}\text { Monoclonal de } \\
\text { conejo }\end{array}$ & $\begin{array}{l}1 / 500 \\
1 / 400\end{array}$ & ab109463 & Abcam \\
\hline $\begin{array}{c}\text { Dimetil- } \\
\text { histona H4 } \\
\text { (Lys20) }\end{array}$ & $\begin{array}{c}\text { Policlonal de } \\
\text { conejo }\end{array}$ & $\begin{array}{l}1 / 500 \\
1 / 100\end{array}$ & 9759 & Cell Signaling \\
\hline
\end{tabular}

Tabla 6: Lista de anticuerpos primarios y secundarios empleados con su correpondiente dilución para western blot (WB) y/o inmunofluorescencia (IF). 


\section{Resultados}





\section{PAPEL DE VRK1 EN LA RESPUESTA AL DAÑO EN EL ADN CAUSADO POR LA COMBINACIÓN DE OLAPARIB Y RADIACIÓN IONIZANTE}

\subsection{El olaparib sensibiliza a las células tumorales al daño génico inducido por la radiación ionizante}

El uso de radiación ionizante (IR) en el tratamiento contra el cáncer se basa en la generación de especies reactivas de oxígeno (ROS) que causan roturas de cadena sencilla (SSBs) y de doble cadena (DSBs) en el ADN debido a su efecto oxidante (59). Dado que la mayor parte de estas lesiones son de cadena sencilla y que su principal mecanismo de reparación es la escisión de bases (BER), la inhibición de PARP, una enzima clave en este mecanismo de respuesta a estrés oxidativo, sensibiliza a las células tumorales a la radiación ionizante, ya que transforma esas SSBs en DSBs e incrementa significativamente su efecto nocivo sobre el tumor $(125,126)$. Para verificar estos resultados, utilizamos diferentes dosis de olaparib, un inhibidor de PARP ampliamente utilizado en quimioterapia, y de IR, por separado $y$ en combinación, sobre dos tipos celulares tumorales con distinto fondo genético, MDAMB-231 (carcinoma de mama triple negativo) y A549 (adenocarcinoma de pulmón, TP53 +/+), y estudiamos dos marcadores de la DDR que forman focos de reparación, $\mathrm{YH} 2 \mathrm{AX}$, de respuesta temprana, y 53BP1, esencial en la reparación de roturas de doble cadena mediada por unión de extremos no homólogos (NHEJ). Como se puede ver en la figura 12.A, el tratamiento por separado con olaparib $(2,5-5-10 \mu \mathrm{M}) \circ \mathrm{IR}(0,5-$ 1-3 Gy) mostró un aumento dosis-dependiente del número de focos de ambos marcadores en la línea MDA-MB-231. Además, observamos que la combinación de dosis más bajas de olaparib e IR causaban el mismo efecto, en cuanto a número de focos se refiere, que las dosis más altas de cada uno de ellos por separado (Figura 12.B). Tras cuantificar el número de focos de $\mathrm{yH} 2 \mathrm{AX}$ y 53BP1, vimos que la combinación más efectiva que permitía alcanzar los mismos niveles de daño que la dosis más alta de radiación (3 Gy) era la de $5 \mu \mathrm{M}$ de olaparib y 1 Gy de IR (Figura 12.C y D). Al realizar estos mismos experimentos en la otra línea celular, A549, obtuvimos resultados similares, ya que el número de focos de los dos marcadores utilizados no variaba significativamente entre la combinación de olaparib $(5 \mu \mathrm{M})$ e IR (1 Gy) y la dosis más alta de radiación (Figura 13). 

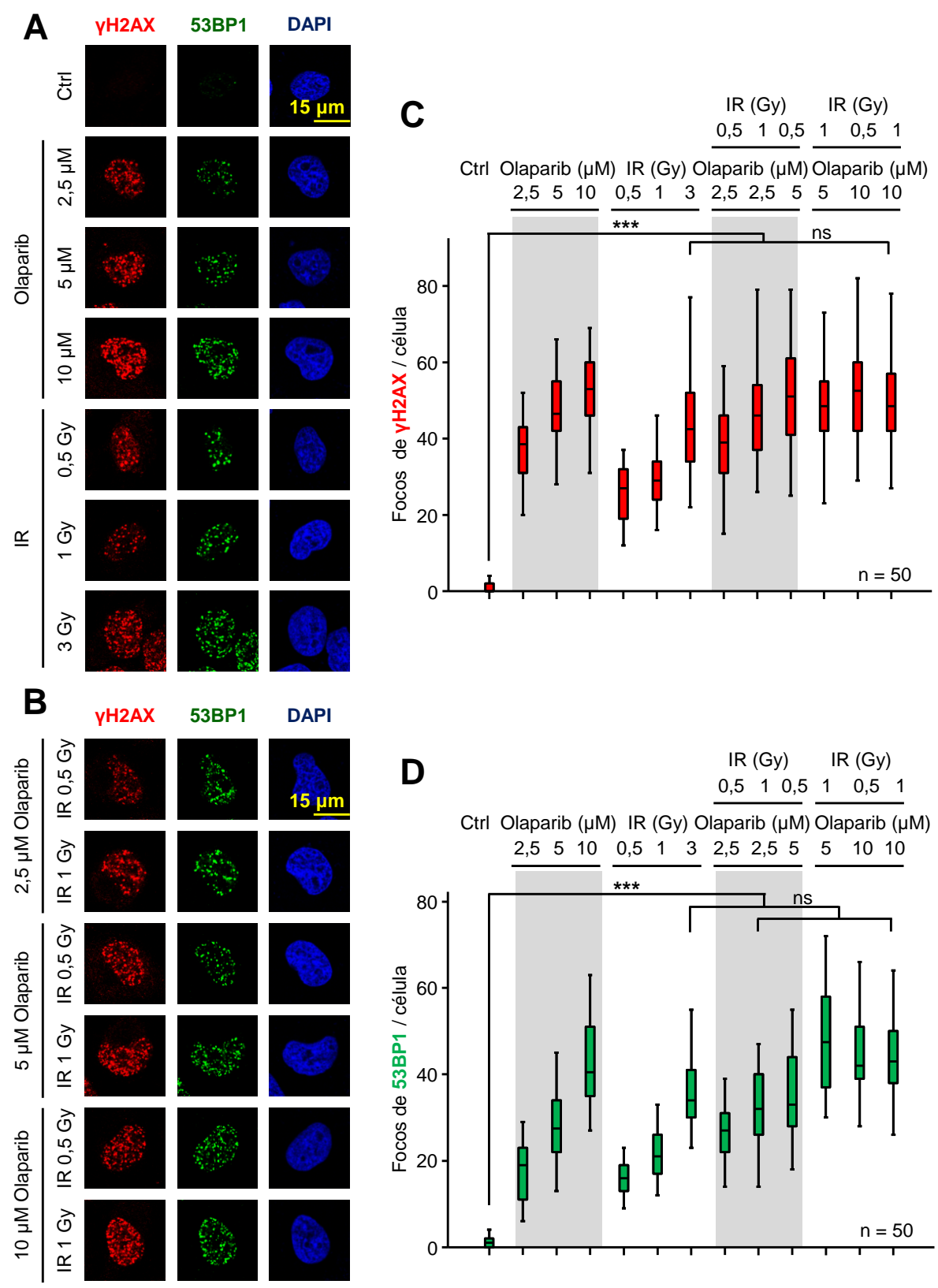
Figura 12: Efecto del olaparib, la IR y su combinación sobre la formación de focos de YH2AX y 53BP1 en la línea celular MDA-MB-231. Estas células se trataron con dosis crecientes de olaparib (2,5-5-10 $\mu \mathrm{M}, 24$ horas) y/o de irradiación (0,5-1-3 Gy). Tras 30 minutos post-IR, se fijaron y se analizó la formación de focos de YH2AX y 53BP1 mediante microscopía confocal. A. Efecto de distintas dosis de olaparib e IR, por separado, sobre la formación de focos de $\mathrm{YH} 2 \mathrm{AX}$ y 53BP1. B. Efecto de la combinación de olaparib e IR sobre el ensamblaje de focos de $\mathrm{YH} 2 \mathrm{AX}$ y 53BP1. C. Cuantificación del número de focos de $\mathrm{yH} 2 \mathrm{AX}$ en respuesta a los tratamientos con olaparib, IR o su combinación. D. Cuantificación del número de focos de 53BP1 tras inducir daño génico con olaparib, IR o su combinación. La significación estadística de las figuras C y D se calculó con el test de comparación múltiple de Dunn's. ns: no significativo; ${ }^{* * *}$, $p<0,001$.
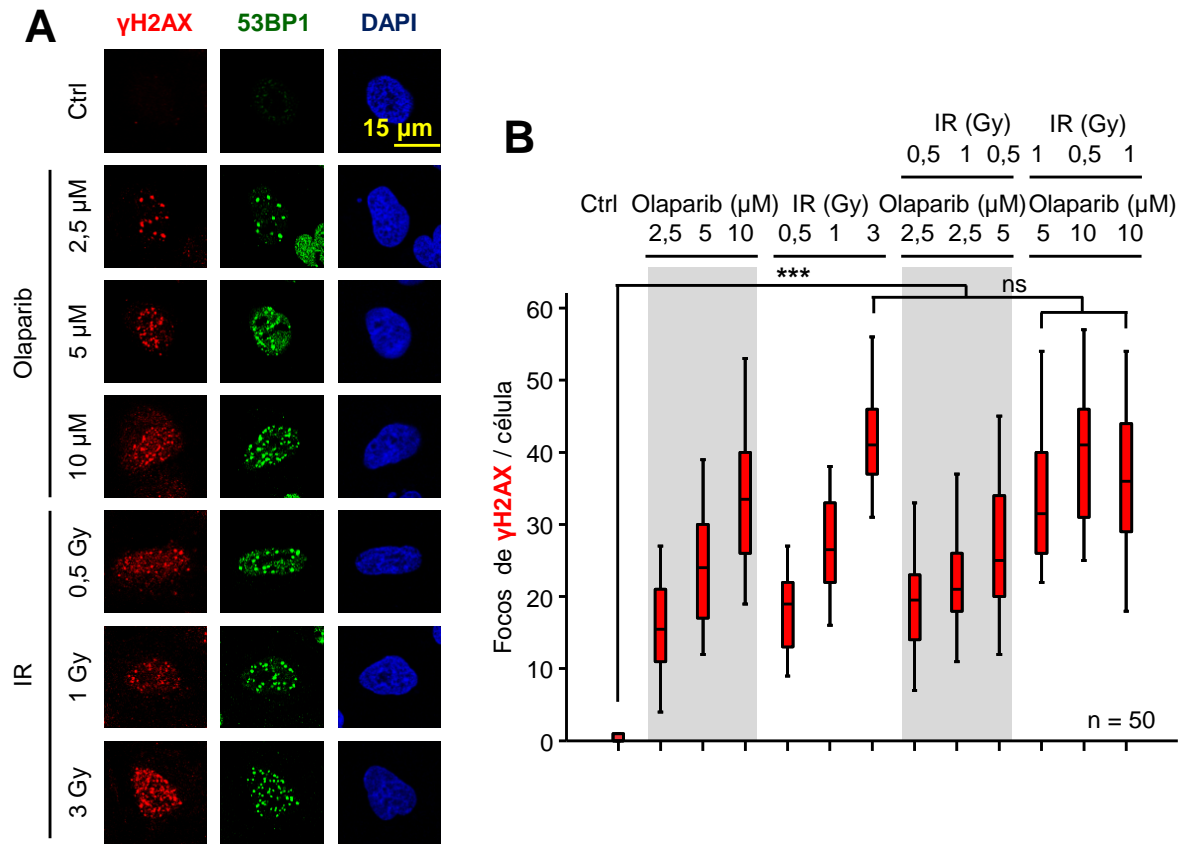

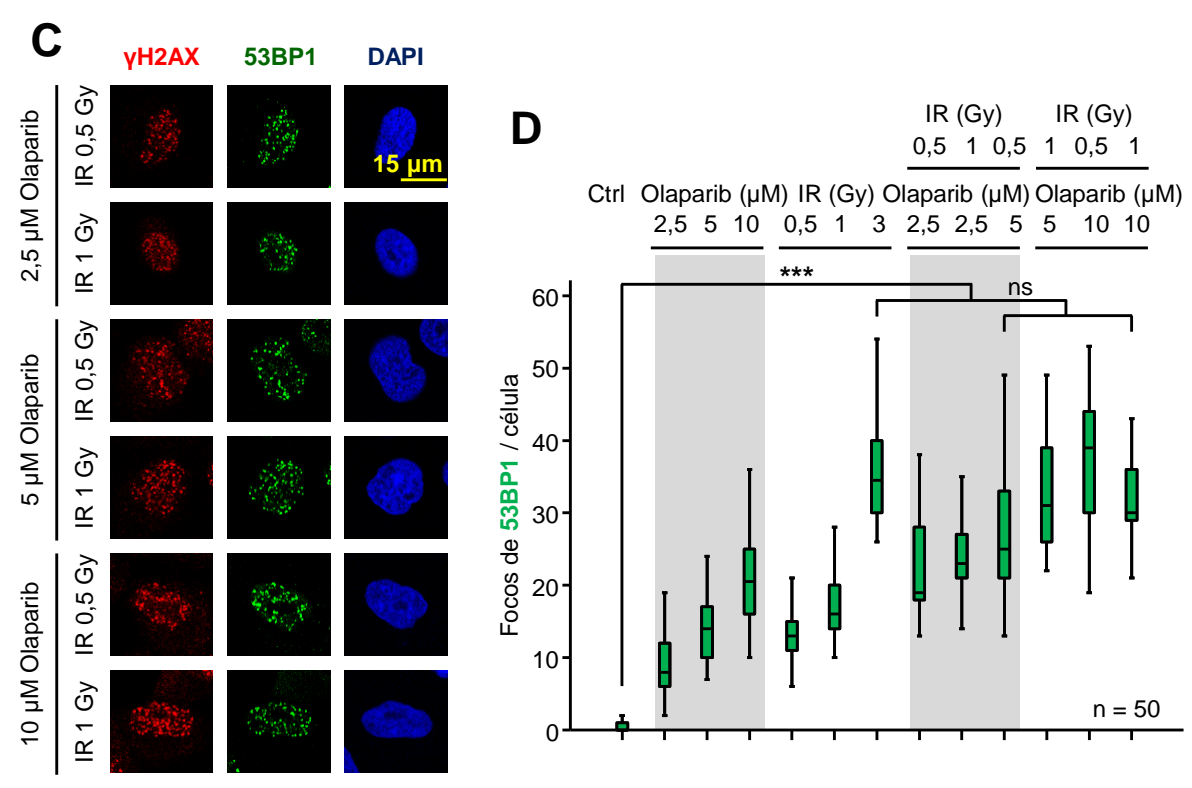

Figura 13: Efecto del olaparib, la IR y su combinación sobre la formación de focos de YH2AX y 53BP1 en la línea celular A549 (TP53 +/+). Tras el tratamiento con dosis crecientes de olaparib (2,5-5-10 $\mu \mathrm{M}, 24$ horas) y/o de irradiación (0,5-1-3 Gy), se fijaron las células (30 minutos después de irradiarlas) y se evaluó la formación de focos de yH2AX y 53BP1 mediante microscopía confocal. A. Efecto de distintas dosis de olaparib e IR, por separado, sobre la formación de focos de $\mathrm{YH} 2 \mathrm{AX}$ y 53BP1. B. Cuantificación del número de focos de $\mathrm{yH} 2 \mathrm{AX}$ en respuesta a los tratamientos con olaparib, IR o su combinación. C. Efecto de la combinación de olaparib e IR sobre el ensamblaje de focos de YH2AX y 53BP1. D. Cuantificación del número de focos de 53BP1 tras inducir daño génico con olaparib, IR o su combinación. La significación estadística de las figuras $B$ y $D$ se calculó con el test de comparación múltiple de Dunn's. ns: no significativo; ${ }^{* \star *}, \mathrm{p}<0,001$.

\subsection{El olaparib sensibiliza a las líneas celulares tumorales que carecen de TP53 al tratamiento con radiación ionizante}

El factor de transcripción p53, codificado por el gen TP53, está implicado en multitud de respuestas a estrés celular, incluido el daño en el ADN, y promueve la parada del ciclo celular o, en su defecto, la apoptosis, mediante una compleja ruta de señalización (223). Para evaluar si el efecto del olaparib sobre la sensibilización de las células tumorales a la radiación ionizante estaba mediado por una respuesta celular dependiente de p53, tratamos la línea de cáncer de pulmón H1299 (TP53 -/-) con distintas dosis de olaparib y radiación ionizante, tanto por separado como en combinación, y analizamos la respuesta al daño en el ADN a través de la formación de focos de $\mathrm{YH} 2 \mathrm{AX}$ y 53BP1. Al igual que ocurría con las otras dos líneas tumorales (MDA-MB-231 y A549, figuras 12 y 13, respectivamente), el número de focos de $\mathrm{YH} 2 \mathrm{AX}$ y $53 \mathrm{BP} 1$ obtenidos tras la combinación de olaparib $(5 \mu \mathrm{M})$ e IR (1 Gy) no 
difería significativamente del obtenido con la dosis más alta de IR (3Gy) (Figura 14). Por tanto, a la vista de estos resultados, podemos decir que la combinación de dosis más bajas de radiación ionizante y olaparib generan la misma cantidad de lesiones en el ADN, cuantificadas a través del número de focos de reparación observados, que las dosis más altas de IR. Además, la respuesta celular al daño génico causado por el olaparib y la IR no depende de p53.

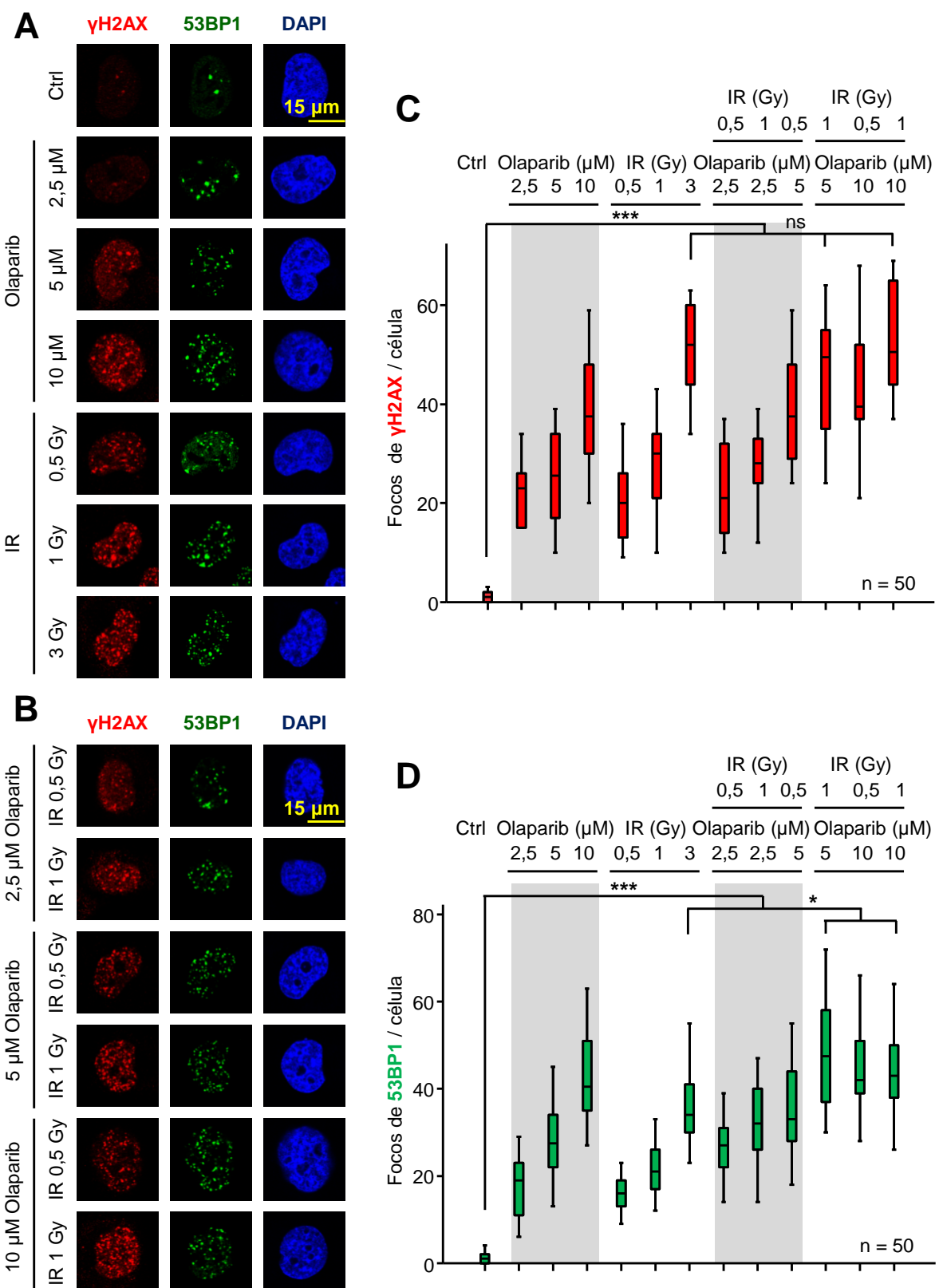


Figura 14: Efecto del olaparib, la IR y su combinación sobre la formación de focos de YH2AX y 53BP1 en la línea celular H1299 (TP53 -/-). Estas células se trataron con dosis crecientes de olaparib (2,5-5-10 $\mu \mathrm{M}, 24$ horas) y/o de irradiación (0,5-1-3 Gy). Tras 30 minutos post-IR, se fijaron y se analizó la formación de focos de $\mathrm{YH} 2 \mathrm{AX}$ y 53BP1 mediante microscopía confocal. A. Efecto de distintas dosis de olaparib e IR, por separado, sobre la formación de focos de $\mathrm{YH} 2 \mathrm{AX}$ y 53BP1. B. Efecto de la combinación de olaparib e IR sobre el ensamblaje de focos de $\mathrm{yH} 2 \mathrm{AX}$ y 53BP1. C. Cuantificación del número de focos de $\mathrm{yH} 2 \mathrm{AX}$ en respuesta a los tratamientos con olaparib, IR o su combinación. D. Cuantificación del número de focos de 53BP1 tras inducir daño génico con olaparib, IR o su combinación. La significación estadística de las figuras $C$ y $D$ se calculó con el test de comparación múltiple de Dunn's. ns: no significativo; *, $p<0,05 ;{ }^{* * *}, p<0,001$.

\subsection{El silenciamiento de VRK1 afecta significativamente a la respuesta al daño en el ADN inducida por olaparib e IR, y es independiente de p53}

Como se ha mencionado en la introducción, VRK1 es una quinasa de la cromatina que actúa a distintos niveles de la respuesta al daño en el $\operatorname{ADN}(85,86,101,180)$. Tras demostrar el efecto sinérgico del olaparib y la radiación ionizante sobre la formación de focos de $\mathrm{yH} 2 \mathrm{AX}$ y 53BP1 en distintas líneas celulares, quisimos determinar si la formación de estos focos de reparación se veía afectada en ausencia de VRK1. Con este objetivo, silenciamos la expresión génica de VRK1 en la línea A549 utilizando un ARN de interferencia (ARNi) específico frente a esta quinasa (siVRK1-02), durante 72 horas, y comparamos su efecto con una población control, transfectada con un ARNi sin diana específica (siCtrl). Tras 48 horas de silenciamiento, tratamos las células correspondientes con olaparib $(5-10 \mu \mathrm{M})$ durante 24 horas $y$, pasado este tiempo, las irradiamos (1-3 Gy). Además, incluimos la combinación de olaparib ( $5 \mu \mathrm{M}, 24$ horas) e IR (1 Gy) que permitía reducir las dosis de ambos tratamientos. Treinta minutos después de irradiar las células, las fijamos y analizamos la respuesta al daño génico utilizando los mismos marcadores que en los apartados anteriores, los focos de $\mathrm{HH} 2 \mathrm{AX}$ y 53BP1. En la línea celular A549, se observó una disminución significativa del número de focos de ambas proteínas tras el silenciamiento de VRK1, tanto en los tratamientos individuales con distintas dosis de olaparib o radiación, como en la combinación de ambos (Figura 15). 

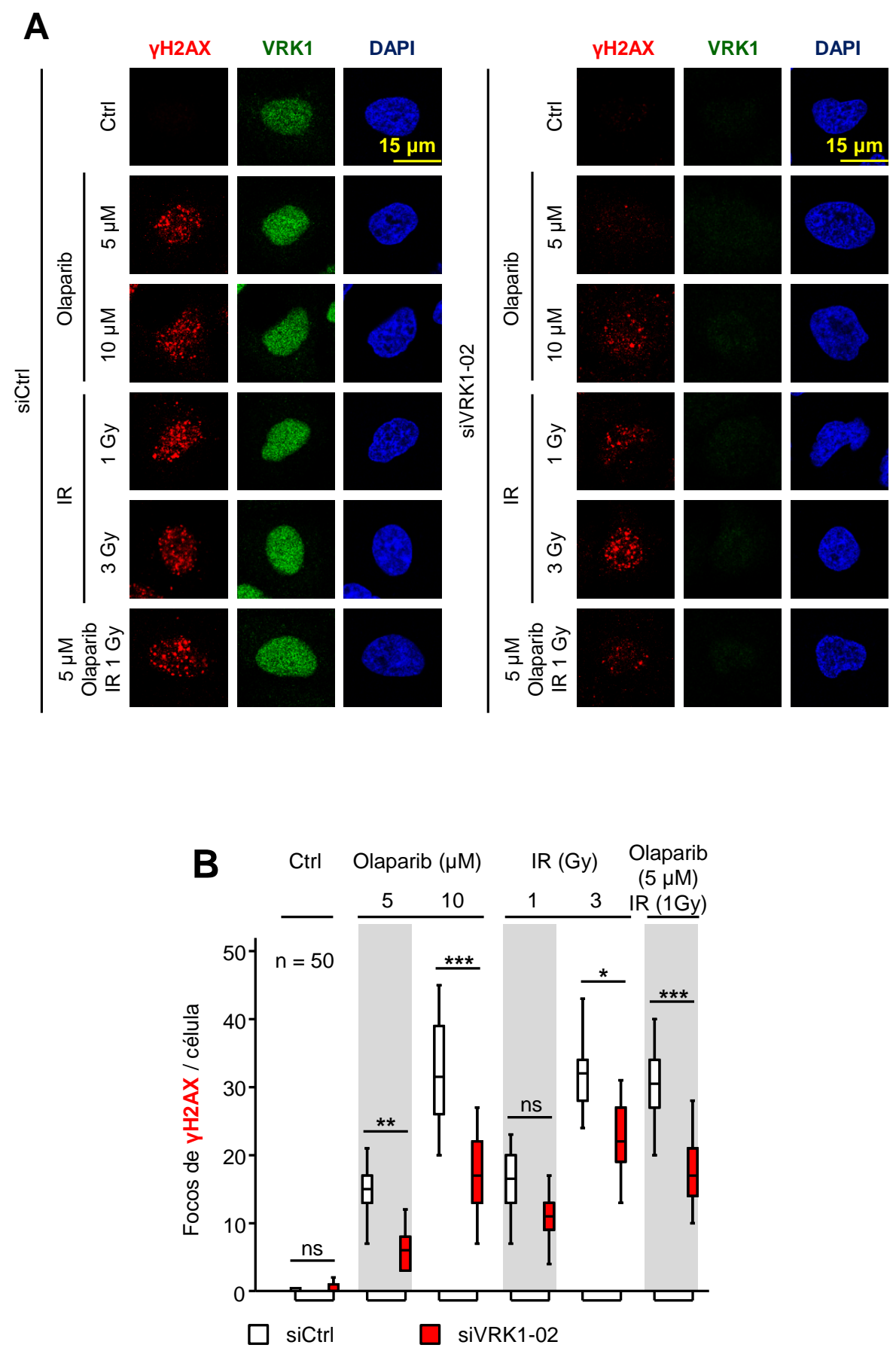


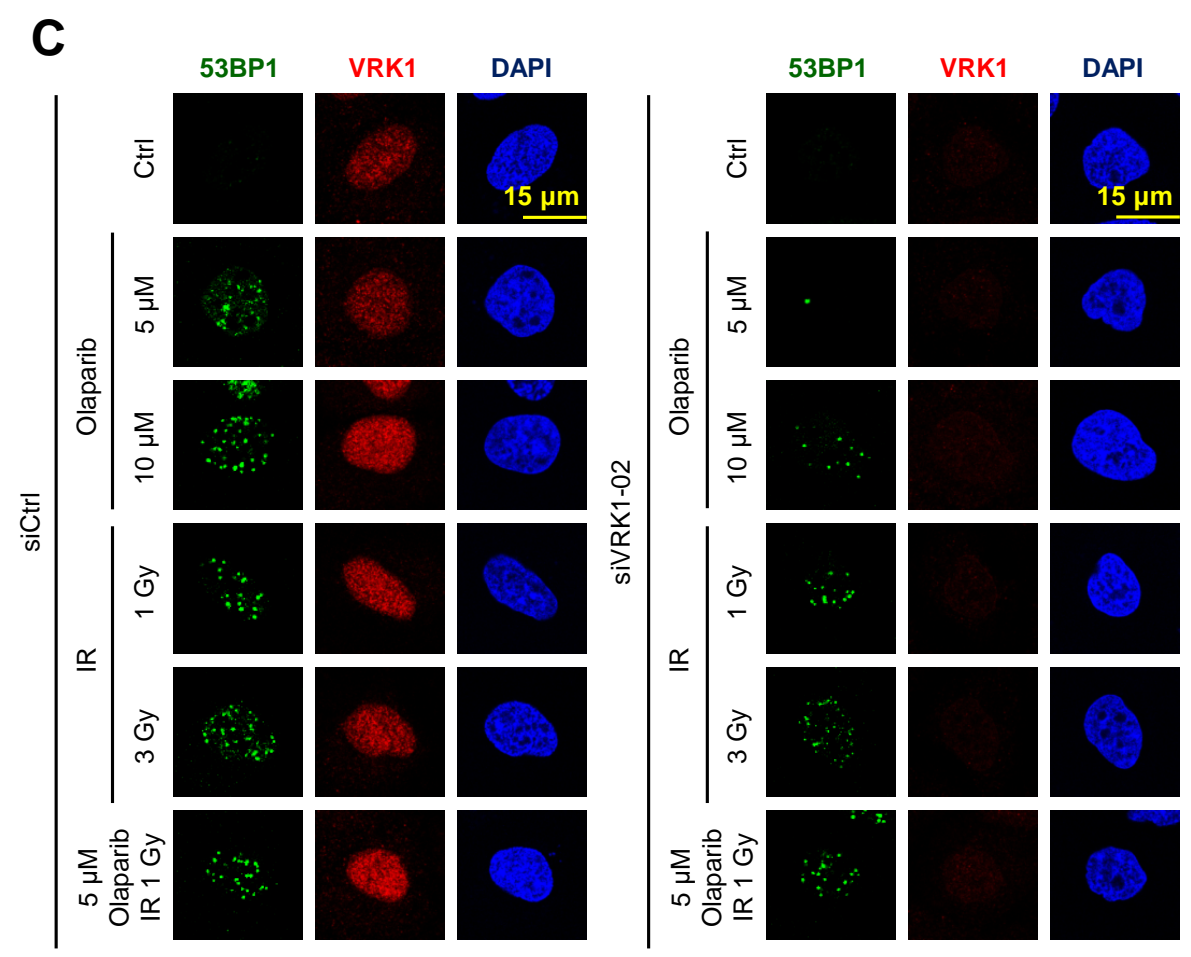

D Ctrl Olaparib $(\mu \mathrm{M}) \quad$ IR (Gy) $\begin{gathered}\text { Olaparib } \\ (5 \mu \mathrm{M})\end{gathered}$

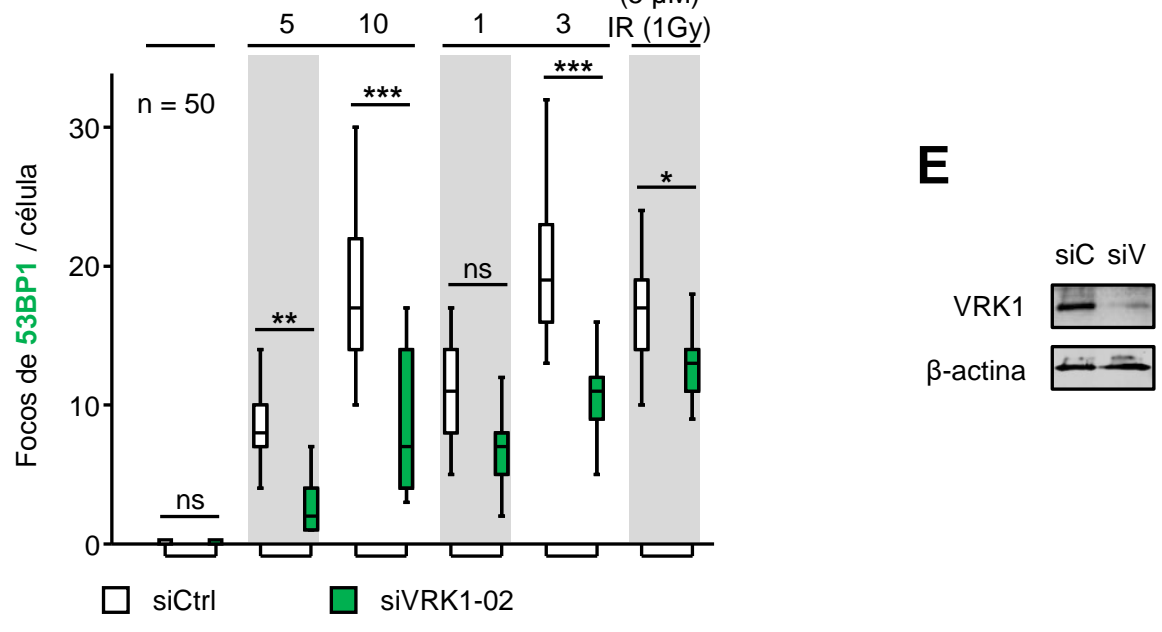


Figura 15: El silenciamiento de VRK1 interfiere en la formación de focos de $\mathrm{YH} 2 \mathrm{AX}$ y 53BP1 tras la inducción de daño génico con olaparib y/o IR en la línea celular A549 (TP53 $+/+$ ). Se transfectaron estas células con dos ARNi (siCtrl y siVRK1-02) y, 48 horas después, se trataron con olaparib $(5-10 \mu \mathrm{M})$. Tras 72 horas de silenciamiento y 24 de incubación con olaparib, se irradiaron las células correspondientes (1-3 Gy) y, pasados 30 minutos, se evaluó la formación de focos de $\mathrm{YH} 2 \mathrm{AX}$ y 53BP1 mediante microscopía confocal. A. Efecto del silenciamiento de VRK1 sobre la formación de focos de $\mathrm{yH} 2 \mathrm{AX}$ tras el tratamiento con olaparib, IR y su combinación. B. Cuantificación del número de focos de $\mathrm{yH} 2 \mathrm{AX}$ en respuesta a los tratamientos con olaparib, IR o su combinación, tanto en presencia como en ausencia de VRK1. La significación estadística se calculó con el test de comparación múltiple de Dunn's. C. Efecto del silenciamiento de VRK1 sobre la formación de focos de 53BP1 tras el tratamiento con olaparib, IR y su combinación. D. Cuantificación del número de focos de 53BP1 tras inducir daño génico con olaparib, IR o su combinación. La significación estadística se calculó con el test de comparación múltiple de Dunn's. E. Comprobación del silenciamiento de VRK1 mediante western blot. siCtrl: siC; siVRK1-02: siV. ns: no significativo; ${ }^{*}, p<0,05 ;{ }^{* \star}, p<0,01 ;{ }^{* \star *}, p<0,001$.

Para comprobar que el efecto del silenciamiento de VRK1 no dependía de p53, repetimos el mismo experimento, pero, en este caso, utilizando la línea celular H1299 (TP53 -/-). Los resultados obtenidos fueron muy similares a los de la línea A549 (Figura15), ya que el silenciamiento de esta quinasa también condujo a una reducción significativa de los focos de $\mathrm{yH} 2 \mathrm{AX}$ y 53BP1 tras el tratamiento con olaparib, IR o su combinación (Figura 16).

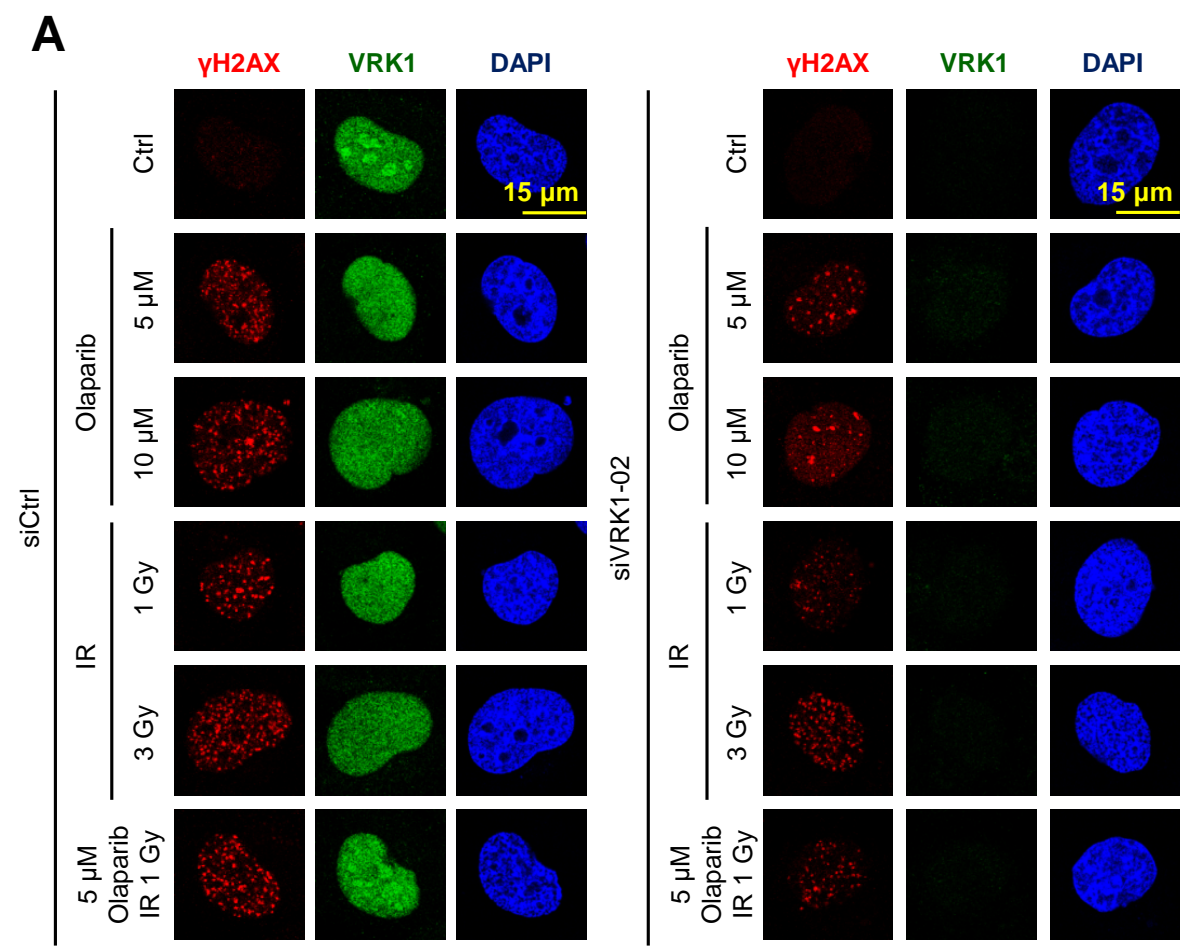



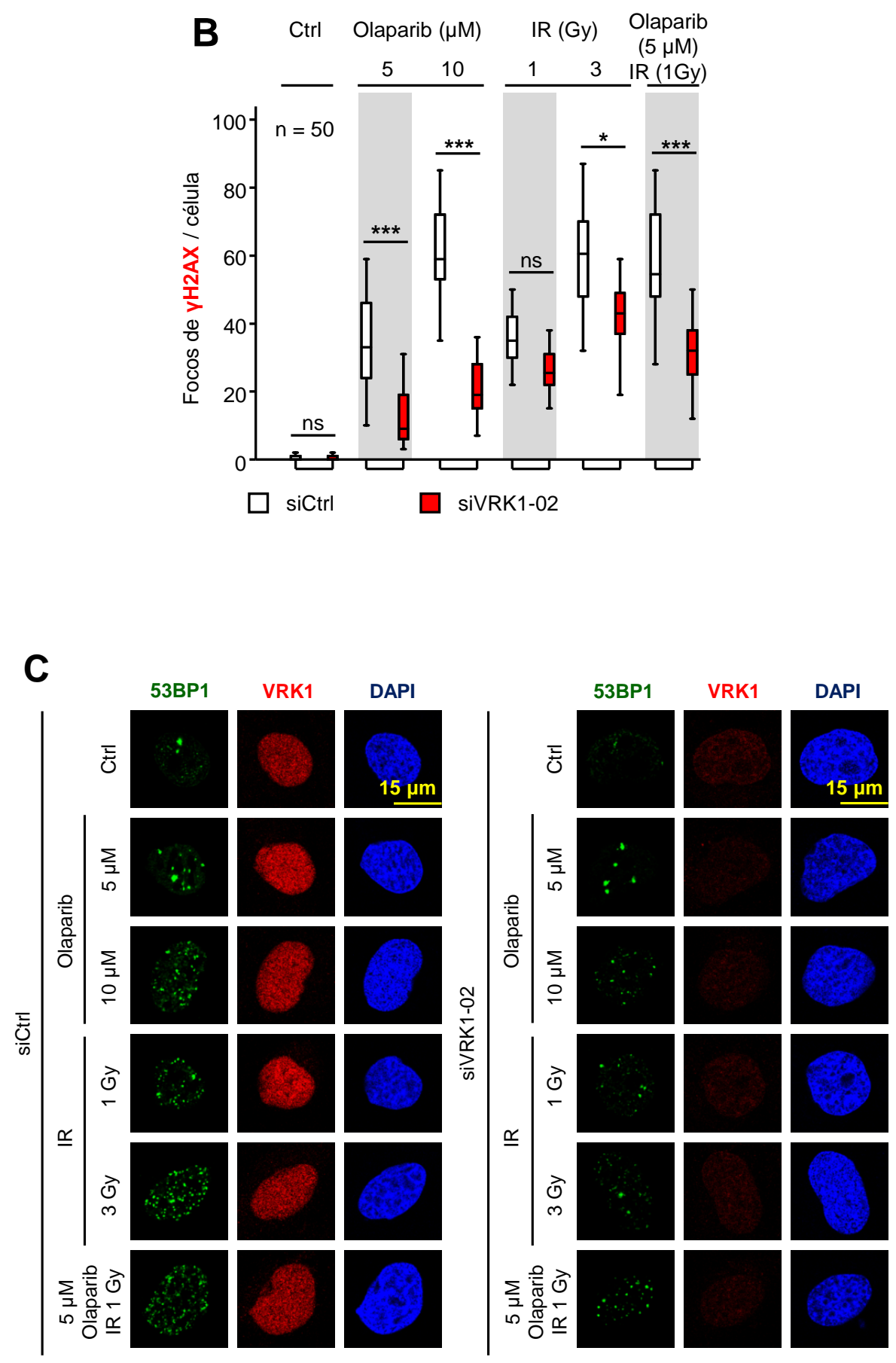


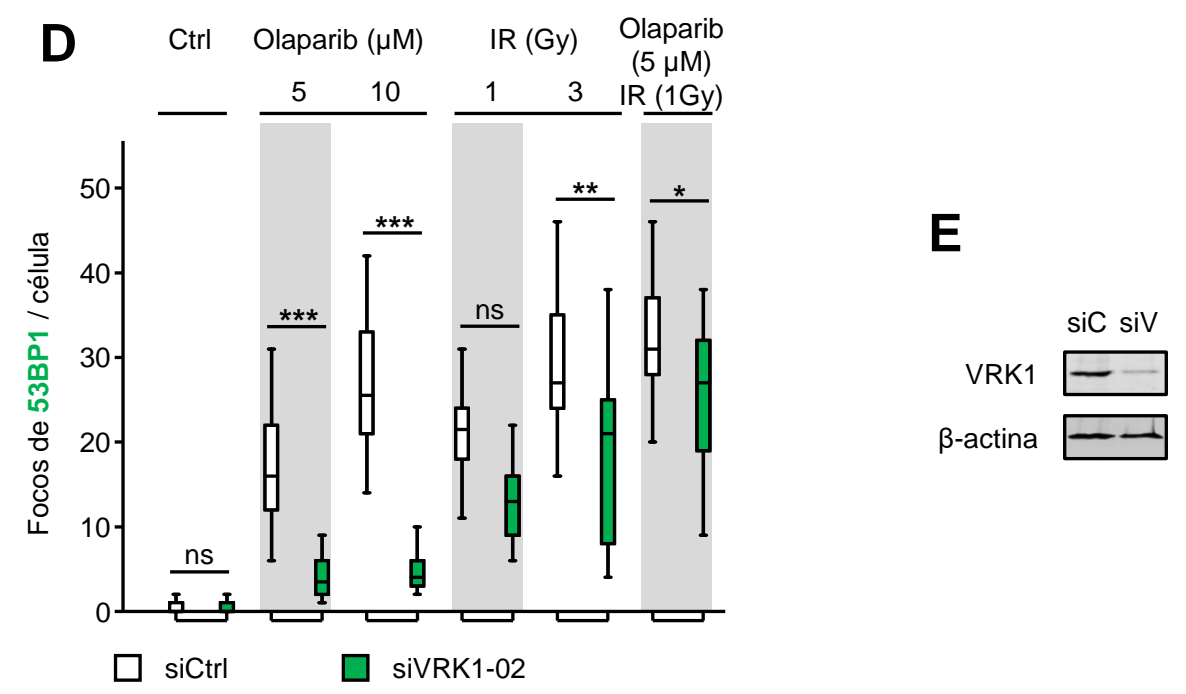

Figura 16: El silenciamiento de VRK1 interfiere en la formación de focos de yH2AX y 53BP1 tras la inducción de daño génico con olaparib y/o IR en la línea celular H1299 (TP53 -/-). Se silenció la expresión génica de VRK1 durante 72 horas y las células que se trataron con olaparib $(5-10 \mu \mathrm{M})$ se incubaron 24 horas con el fármaco. Pasadas las 72 horas de silenciamiento, se irradiaron las células correspondientes (1-3 Gy) y, 30 minutos después, se analizó la formación de focos de $\mathrm{HH} 2 \mathrm{AX}$ y 53BP1 mediante microscopía confocal. A. Efecto del silenciamiento de VRK1 sobre la formación de focos de $\mathrm{yH} 2 \mathrm{AX}$ tras el tratamiento con olaparib, $\mathrm{IR}$ y su combinación. B. Cuantificación del número de focos de $\mathrm{yH} 2 \mathrm{AX}$ en respuesta a los tratamientos con olaparib, IR o su combinación, tanto en presencia como en ausencia de VRK1. La significación estadística se calculó con el test de comparación múltiple de Dunn's. C. Efecto del silenciamiento de VRK1 sobre la formación de focos de 53BP1 tras el tratamiento con olaparib, IR y su combinación. D. Cuantificación del número de focos de 53BP1 tras inducir daño génico con olaparib, IR o su combinación. La significación estadística se calculó con el test de comparación múltiple de Dunn's. E. Análisis de los niveles proteicos de VRK1 tras el silenciamiento génico. siCtrl: siC; siVRK1-02: siV. ns: no significativo; ${ }^{*}, p<0,05 ;{ }^{* *}, p<0,01 ;{ }^{* * *}$, $\mathrm{p}<0,001$.

\subsection{La ausencia de suero en el medio de cultivo ralentiza la tasa de crecimiento de las células tumorales}

Todos los experimentos realizados hasta ahora se llevaron a cabo con células tumorales crecidas en medio de cultivo suplementado con suero al 10\%. Sin embargo, nos preguntamos cómo se comportarían estas líneas celulares tumorales ante la ausencia de factores mitogénicos en el medio. Con este fin, realizamos curvas de crecimiento en células A549 o H1299 crecidas en presencia de suero al 10\% O al $0,5 \%$ (condiciones en las que estas células únicamente reciben señales de supervivencia procedentes del suero). Tras analizar los datos obtenidos, vimos que el número de células de A549 (Figura 17.A) y H1299 (Figura 17.B) era significativamente 
menor después de incubarlas durante al menos 48 horas con medio sin suero $(0,5 \%)$ con respecto a las células control (10\% FBS).
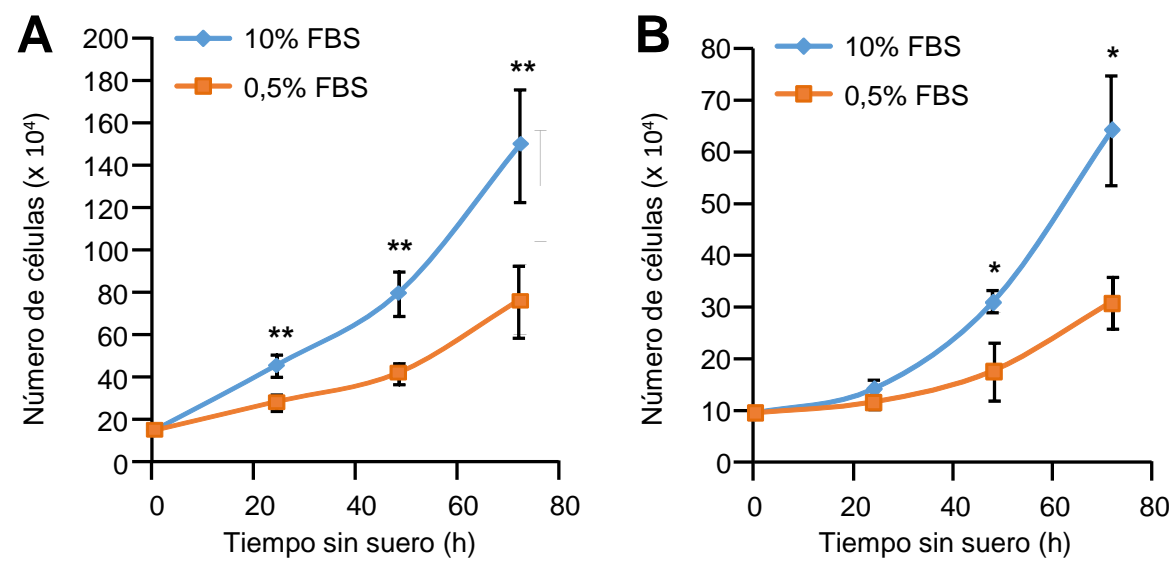

Figura 17: El crecimiento de las células tumorales A549 y H1299 se ralentiza al retirar el suero del medio de cultivo. Se sembró el mismo número de células en dos placas iguales para cada línea y cada tiempo, y, 24 horas después, se sustituyó el medio completo (10\% FBS) por medio con suero al $0,5 \%$. Posteriormente, se cuantificaron las células cada 24 horas (24-48-72 horas) utilizando la cámara de Nuebauer. A. Curvas de crecimiento de las células A549 en presencia o ausencia de suero $(0,5 \%)$. B. Curvas de crecimiento de la línea celular $\mathrm{H} 1299$ con o sin suero $(0,5 \%)$. El análisis estadístico se realizó a partir de los datos de tres experimentos independientes para cada línea celular utilizando la $t$ de Student. ${ }^{*}, p<0,05 ;{ }^{* *}, p<0,01$.

El interés de estos datos radica en que el daño génico, independientemente de su origen, no es exclusivo de células en proliferación, sino que también afecta a todas aquellas que no se están dividiendo, como es el caso de las neuronas o de las células madre tumorales. Por esta razón, y en base a los resultados obtenidos, los siguientes experimentos se llevaron a cabo tras el crecimiento de las células correspondientes con medio al $0,5 \%$ de suero durante 48 horas.

\subsection{El silenciamiento de VRK1 interfiere en la acetilación de la histona $\mathrm{H} 4$ en la lisina 16 inducida por olaparib e IR}

Tras la inducción del daño génico, la cromatina se relaja localmente en las regiones donde se ha producido la lesión y se activa la respuesta apropiada en función del tipo de daño (224). Este proceso depende de la acetilación de histonas, necesaria para el reclutamiento de la maquinaria de reparación, y se puede monitorizar utilizando la acetilación de la histona $\mathrm{H} 4$ en la lisina 16 (225). Además, se sabe que la pérdida de esta acetilación se asocia con defectos en la reparación del ADN (226). Por todo esto, quisimos estudiar las variaciones de esta acetilación en respuesta al tratamiento con 
olaparib, IR o su combinación, tanto en presencia como en ausencia de VRK1, en las líneas A549 (Figura 18) y H1299 (Figura 19). Tras analizar la acetilación de la H4K16 en los dos tipos celulares mencionados anteriormente, observamos que los niveles de la H4K16ac aumentaban significativamente tras la inducción de daño génico, alcanzando su nivel más alto con $10 \mu \mathrm{M}$ de olaparib, 3 Gy de IR y la combinación de 5 $\mu \mathrm{M}$ de olaparib con 1 Gy de IR en presencia de VRK1. Por el contrario, el silenciamiento de esta quinasa redujo considerablemente la acetilación de la H4K16 en ambas líneas. Estos datos demostraron que los cambios en la acetilación de esta histona debidos a la ausencia de VRK1 no dependen de respuestas mediadas por p53 y sugieren que esta quinasa podría tener un papel relevante en la regulación de las etapas posteriores de la respuesta al daño.

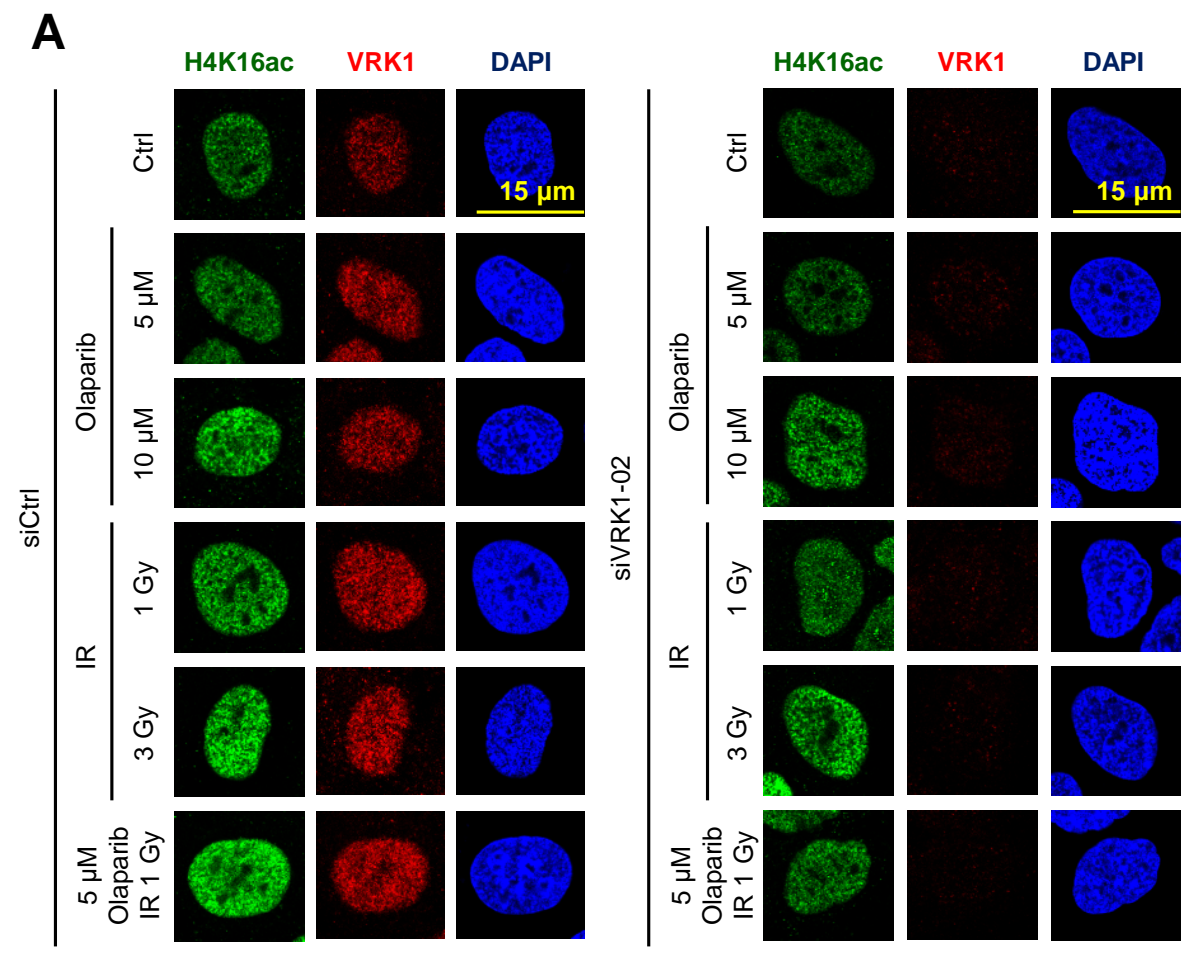




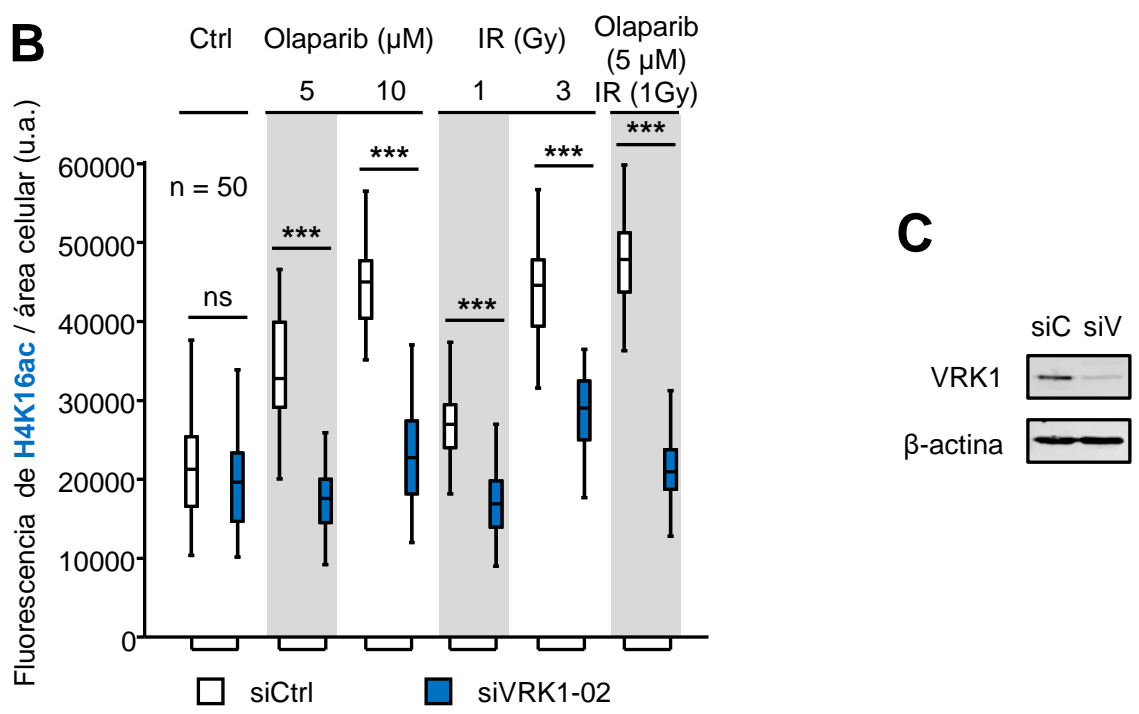

Figura 18: La ausencia de VRK1 reduce significativamente la acetilación de la H4K16 tras el tratamiento con olaparib, IR o su combinación en células A549 (TP53 +/+). Se transfectaron estas células con 2 ARNi (siCtrl y siVRK1-02, 72 horas), se retiró el suero del medio de cultivo 24 horas después (48 horas, $0,5 \%$ FBS), se trataron las células correspondientes con olaparib $(5-10 \mu \mathrm{M})$ y/o se irradiaron (1-3 Gy) pasadas 24 horas. A continuación (30 minutos post-IR), se evaluaron los cambios en la H4K16ac mediante microscopía confocal. A. Izda. Variaciones en la acetilación de la H4K16 en respuesta al tratamiento con olaparib, IR o su combinación. A. Dcha. Efecto del silenciamiento de VRK1 sobre los niveles de la H4K16ac tras la inducción de daño génico con olaparib, IR y su combinación. B. Cuantificación de la acetilación de la H4K16 asociada a los tratamientos con olaparib e IR, por separado o en combinación, en presencia o ausencia de VRK1. La significación estadística se calculó con el test de comparación múltiple de Dunn's. C. Comprobación del silenciamiento de VRK1 por western blot. siCtrl: siC; siVRK1-02: siV. ns: no significativo; ${ }^{* \star *}, p<0,001$. 

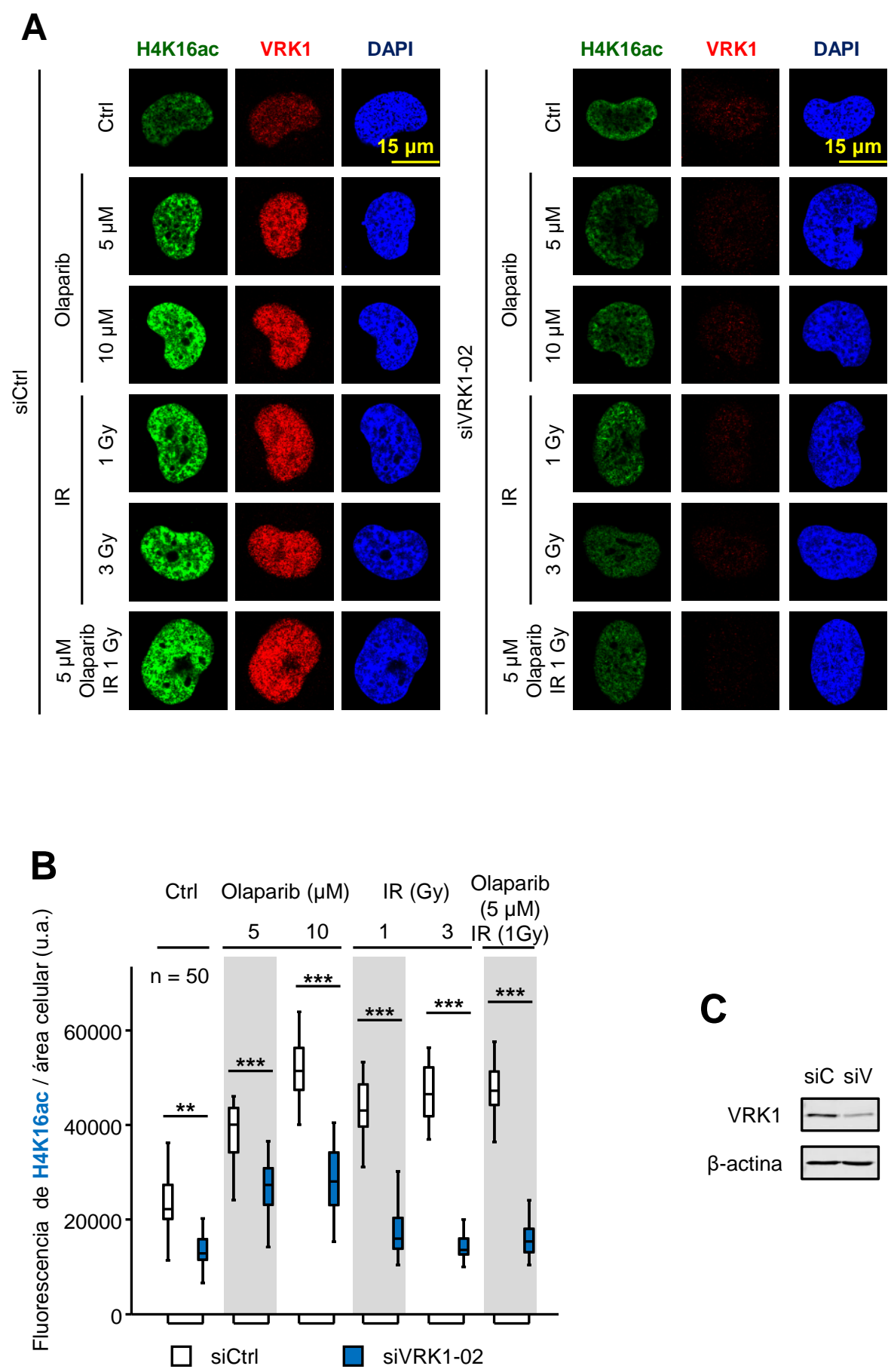

C

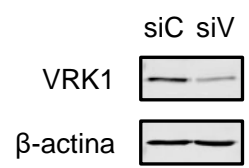


Figura 19: El silenciamiento de VRK1 conlleva una disminución altamente significativa de la acetilación de la H4K16 tras el tratamiento con olaparib e IR por separado, o en combinación, en la línea celular H1299 (TP53 -/-). Se silenció la expresión génica de VRK1 durante 72 horas y se retiró el suero del medio de cultivo 24 horas después (48 horas, 0,5\% FBS). A continuación, las células que se trataron con olaparib (5-10 $\mu \mathrm{M})$ se incubaron 24 horas con el fármaco. Pasadas las 72 horas de silenciamiento, las 48 sin suero y las 24 con olaparib, se irradiaron las células correspondientes (1-3 Gy) y, 30 minutos después, se analizaron los cambios en la H4K16ac mediante microscopía confocal. A. Izda. Variaciones en la acetilación de la H4K16 en respuesta al tratamiento con olaparib, IR o su combinación. A. Dcha. Efecto del silenciamiento de VRK1 sobre los niveles de la H4K16ac tras la inducción de daño génico con olaparib, IR y su combinación. B. Cuantificación de los cambios en la H4K16ac asociados a los tratamientos con olaparib e IR, por separado o en combinación, en presencia o ausencia de VRK1. La significación estadística se calculó con el test ANOVA y la corrección de Bonferroni. C. Análisis de los niveles proteicos de VRK1 tras el silenciamiento génico. siCtrl: siC; siVRK1-02: siV. ${ }^{* \star}, p<0,01 ;{ }^{* * *}, p<0,001$.

\subsection{La respuesta al daño en el ADN causada por olaparib, IR o su combinación mediada por NBS1 se ve afectada en ausencia de VRK1}

El complejo MRN juega un papel esencial durante las primeras etapas de la respuesta al daño génico, tanto en la protección de los extremos generados tras la rotura como en el reclutamiento de proteínas implicadas en la reparación $(81,82)$. Uno de sus componentes, NBS1, se fosforila y se activa rápidamente tras la inducción de daño en el ADN y dicha fosforilación depende, entre otras quinasas, de VRK1 (86). Por esta razón, quisimos saber si el silenciamiento de esta quinasa alteraba el reclutamiento de NBS1 a las zonas dañadas en respuesta a olaparib, IR o su combinación. Cuando tratamos la línea celular A549 con olaparib, IR o ambos, vimos un incremento considerable del número de focos de NBS1 en respuesta a las dosis más altas de olaparib (10 $\mathrm{M}$ ), IR (3 Gy) y la combinación de ambos (5 $\mu \mathrm{M}$ de olaparib + 1 Gy de $I R)$, con respecto a las células control. Sin embargo, el silenciamiento génico de la quinasa VRK1 impedía la acumulación de NBS1 en las zonas del ADN dañadas (Figura 20), poniendo de manifiesto que esta quinasa participa activamente en la correcta formación de focos de NBS1. 

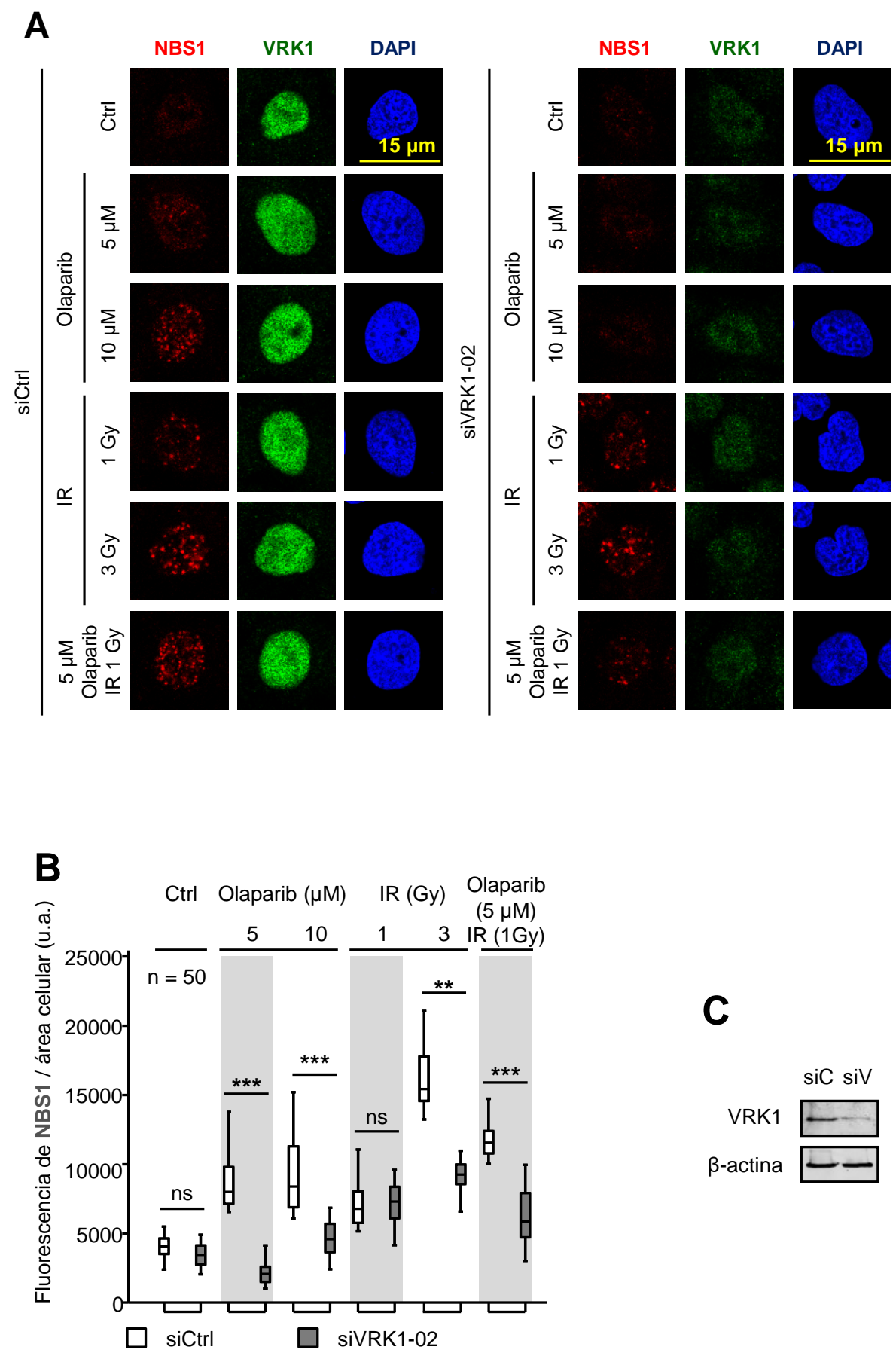

C

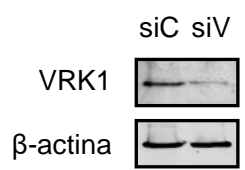


Figura 20: El silenciamiento de VRK1 reduce significativamente la acumulación de NBS1 en las zonas dañadas tras el tratamiento con olaparib, IR o su combinación en células A549 (TP53 +/+). Se transfectaron estas células con 2 ARNi (siCtrl y siVRK1-02, 72 horas), se retiró el suero del medio de cultivo 24 horas después (48 horas, 0,5\% FBS), se trataron las células correspondientes con olaparib $(5-10 \mu \mathrm{M})$ y/o se irradiaron (1-3 Gy) pasadas 24 horas. A continuación (30 minutos post-IR), se evaluó la formación de focos de NBS1 mediante microscopía confocal. A. Izda. Variaciones en los niveles de NBS1 en respuesta al tratamiento con olaparib, IR o su combinación. A. Dcha. Efecto del silenciamiento de VRK1 sobre los focos de NBS1 tras la inducción de daño génico con olaparib, IR y su combinación. B. Cuantificación de los focos de NBS1, medidos a través de su fluorescencia, asociados a los tratamientos con olaparib e IR, por separado o en combinación, en presencia o ausencia de VRK1. La significación estadística se calculó con el test de comparación múltiple de Dunn's. C. Comprobación del silenciamiento de VRK1 por western blot. siCtrl: siC; siVRK1-02: siV. ns: no significativo; ${ }^{* *}, p<0,01 ;{ }^{* \star *}, p<0,001$.

También quisimos analizar si este efecto era independiente de ATM, dado que esta quinasa también fosforila a NBS1 en respuesta al daño génico (87). Con este fin, tratamos las células HT144 (ATM -/-) con olaparib e IR, por separado, o con su combinación, y evaluamos su capacidad para formar focos de reparación de NBS1. En respuesta a olaparib $(5-10 \mu \mathrm{M})$, IR (1-3 Gy), o la combinación de ambos tratamientos ( $5 \mu \mathrm{M}$ de olaparib +1 Gy de IR), observamos que se formaban focos de NBS1 en las regiones del ADN dañadas en ausencia de ATM. Por el contrario, el silenciamiento de VRK1 redujo significativamente la formación de estos focos (Figura 21), demostrando que esta quinasa responde al daño en el ADN de manera independiente a ATM. Además, realizamos un experimento similar en la línea H1299 (TP53 -/-) y comprobamos que la ausencia de VRK1 en estas células carentes de p53 también se traducía en una reducción clara de la acumulación de NBS1 en las zonas dañadas en respuesta a olaparib, IR o la combinación de ambos tratamientos (Figura 22). 

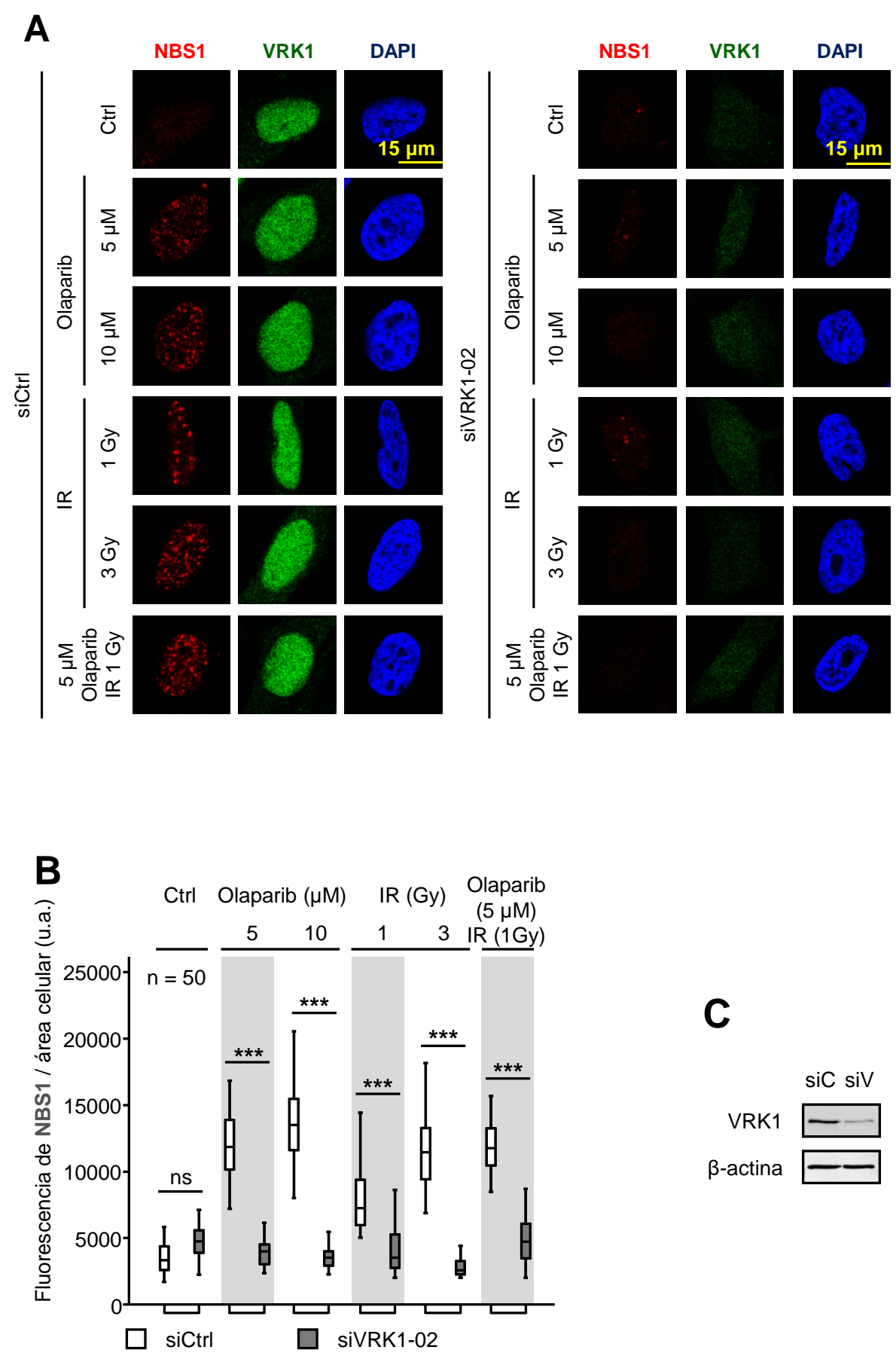
Figura 21: El efecto del silenciamiento de VRK1 sobre la formación de focos de NBS1 tras el tratamiento con olaparib, IR o su combinación no depende de ATM. Tras silenciar la expresión génica de $V R K 1$ (72 horas) y retirar el suero del medio de cultivo (48 horas, 0,5\% FBS) de las células HT144 (ATM -/-), se trataron las células correspondientes con olaparib $(5-10 \mu \mathrm{M})$ y/o se irradiaron (1-3 Gy) 24 horas después. Pasados 30 minutos, se analizó la formación de focos de NBS1 mediante microscopía confocal. A. Izda. Variaciones en los niveles de NBS1 en respuesta al tratamiento con olaparib, IR o su combinación. A. Dcha. Efecto del silenciamiento de VRK1 sobre los focos de NBS1 tras la inducción de daño génico con olaparib, IR y su combinación. B. Cuantificación de los focos de NBS1, medidos a través de su fluorescencia, asociados a los tratamientos con olaparib, IR o su combinación, en presencia o ausencia de VRK1. La significación estadística se calculó con el test de comparación múltiple de Dunn's. C. Análisis de los niveles proteicos de VRK1 tras el silenciamiento génico. siCtrl: siC; siVRK1-02: siV. ns: no significativo; ${ }^{* \star *}, p<0,001$.

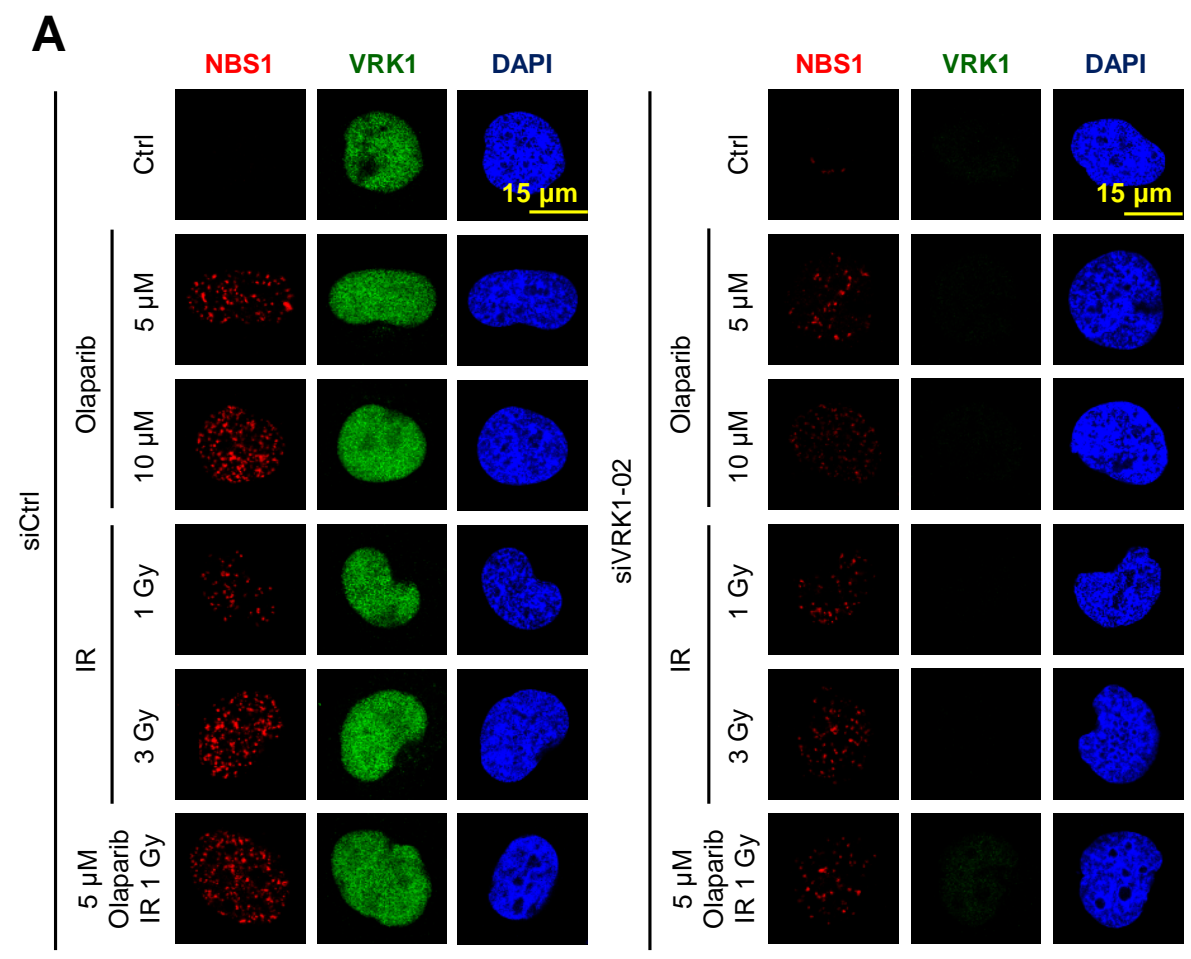




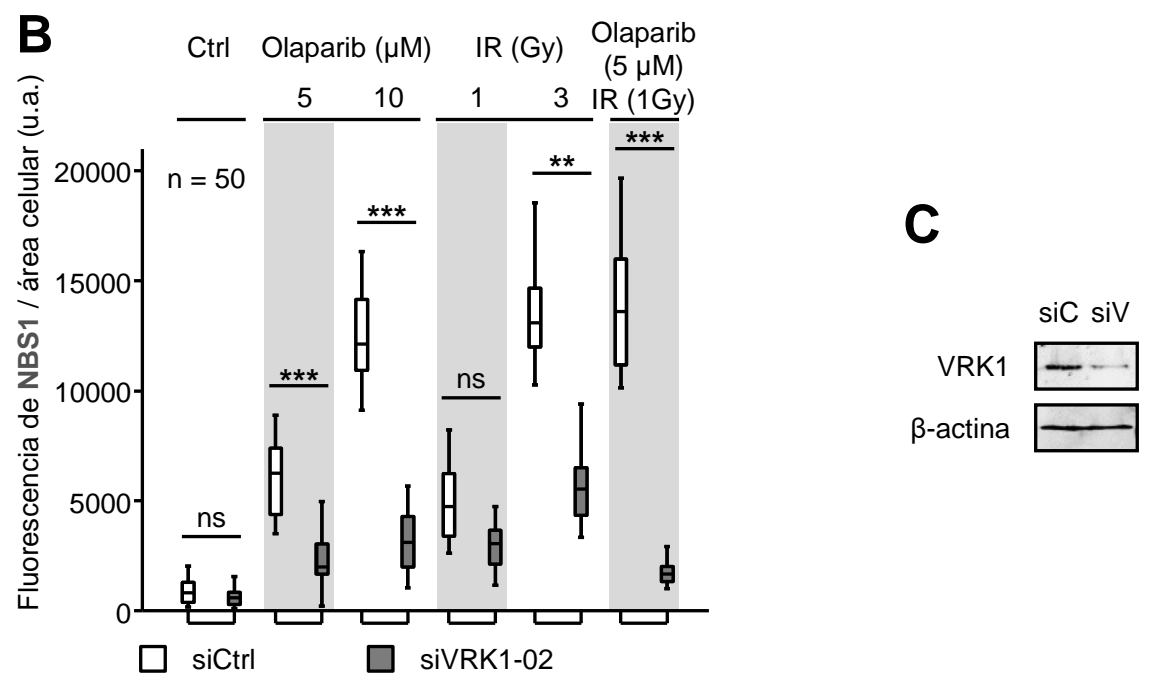

Figura 22: La ausencia de VRK1 impide la formación de focos de NBS1 tras el tratamiento con olaparib, IR o su combinación en células H1299 (TP53 -/-). Se transfectaron estas células con 2 ARNi (siCtrl y siVRK1-02, 72 horas), se retiró el suero del medio de cultivo 24 horas después (48 horas, $0,5 \%$ FBS), se trataron las células correspondientes con olaparib $(5-10 \mu \mathrm{M})$ y/o se irradiaron (1-3 Gy) pasadas 24 horas. A continuación (30 minutos post-IR), se evaluó la formación de focos de NBS1 mediante microscopía confocal. A. Izda. Variaciones en los niveles de NBS1 en respuesta al tratamiento con olaparib, IR o su combinación. A. Dcha. Efecto del silenciamiento de VRK1 sobre los focos de NBS1 tras la inducción de daño génico con olaparib, IR y su combinación. B. Cuantificación de los focos de NBS1, medidos a través de su fluorescencia, asociados a los tratamientos con olaparib e IR, por separado o en combinación, en presencia o ausencia de VRK1. La significación estadística se calculó con el test de comparación múltiple de Dunn's. C. Comprobación del silenciamiento de VRK1 por western blot. siCtrl: siC; siVRK1-02: siV. ns: no significativo; ${ }^{* *}, p<0,01 ;{ }^{* * *}, p<0,001$.

\subsection{El silenciamiento de VRK1 interfiere en la respuesta al daño en el ADN inducida por el tratamiento con olaparib, IR o su combinación en células en reposo}

Como se ha mencionado anteriormente, la respuesta al daño en el ADN implica la reorganización local de la cromatina. La radiación ionizante es una fuente conocida de estrés oxidativo que causa daño en el ADN y el olaparib, al ser un inhibidor de PARP, interfiere en la reparación de este tipo de daño. Por tanto, el daño oxidativo provocado por la combinación de ambos tratamientos conlleva la relajación local de la cromatina y la acumulación de factores de reparación en las zonas donde se ha producido la lesión, un proceso mediado por multitud de proteínas entre las que se encuentra la quinasa humana VRK1 (185). En el caso de que este tipo de roturas en el ADN se produzca en células en reposo (fases G0/G1 del ciclo celular), VRK1 promueve la fosforilación y activación de la histona H2AX (85), de NBS1 (86) y de 53BP1 (101, 
180), ya que las DSBs generadas sólo se pueden reparar por unión de extremos no homólogos (NHEJ). Hasta ahora, hemos demostrado que la ausencia de VRK1 afecta a la acetilación de la cromatina asociada a su relajación y a la respuesta mediada por NBS1 en células que no se están dividiendo, lo que nos llevó a preguntarnos si también alteraba el resto de etapas relacionadas con la reparación del daño generado por olaparib, IR o su combinación. Para validar esta hipótesis, silenciamos la expresión génica de VRK1 y retiramos los factores mitogénicos presentes en el suero del medio de cultivo en la línea celular A549 antes de inducir daño oxidativo con olaparib, IR o su combinación. Hecho esto, analizamos la formación de focos de YH2AX y 53BP1. Como se puede ver en la figura 23, la formación de estos focos asociada al tratamiento con olaparib e IR por separado, o a su uso combinado, se veía afectada significativamente tras silenciar VRK1. 

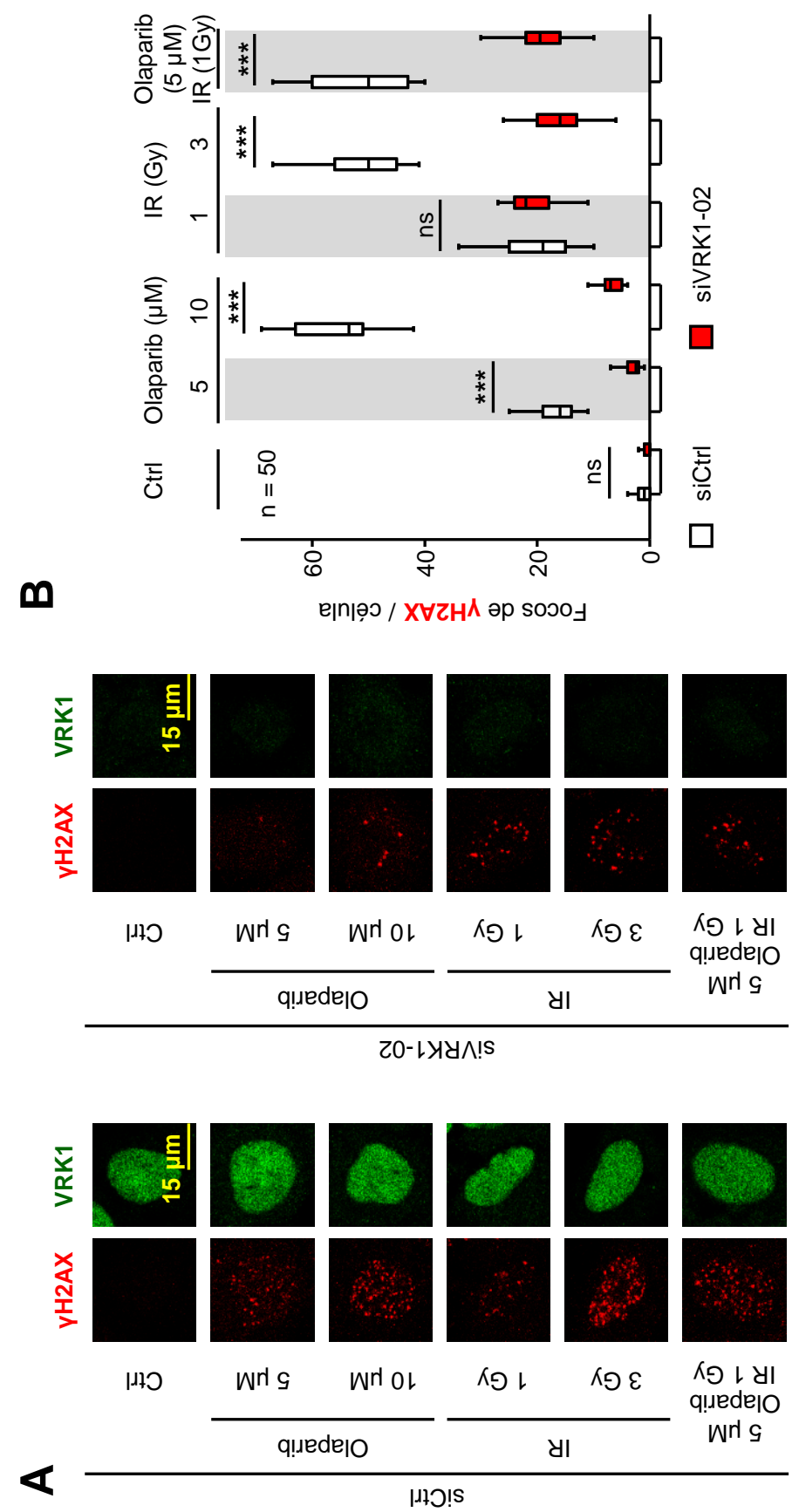

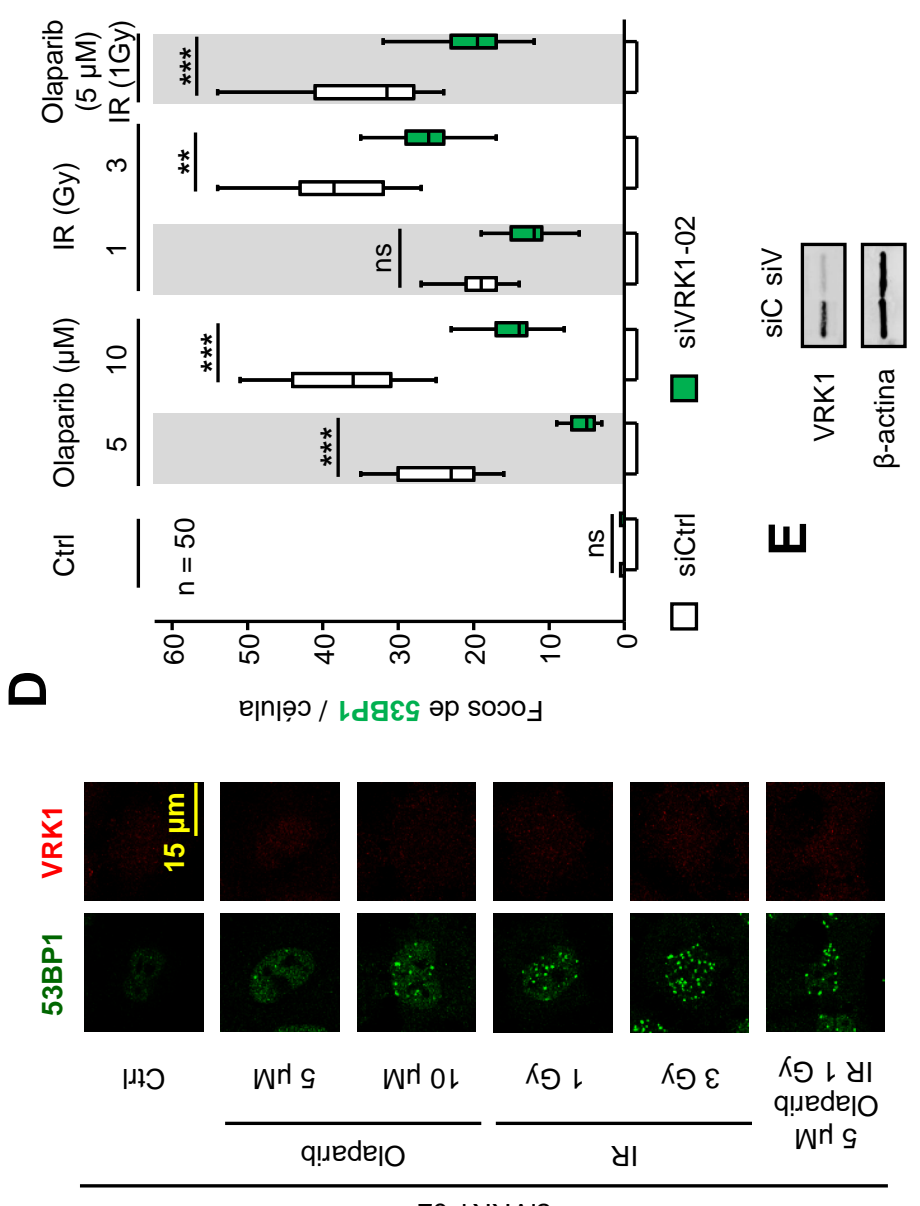

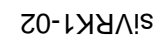

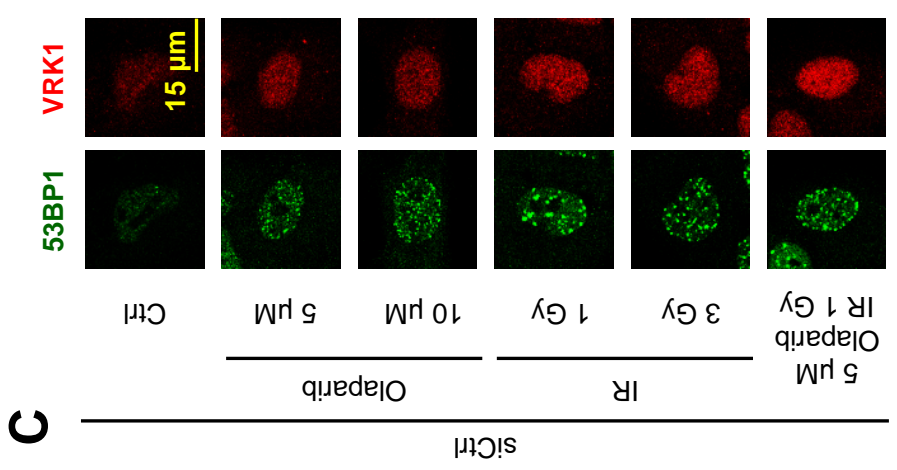


Figura 23: La ausencia de VRK1 altera la formación de focos de yH2AX y 53BP1 en respuesta al tratamiento con olaparib, IR o su combinación en células A549 sin suero $(0,5 \%)$. Se silenció la expresión génica de VRK1 durante 72 horas y se retiró el suero del medio de cultivo 24 horas después (48 horas). A continuación, las células que se trataron con olaparib $(5-10 \mu \mathrm{M})$ se incubaron 24 horas con el fármaco. Pasadas las 72 horas de silenciamiento, las 48 sin suero y las 24 con olaparib, se irradiaron las células correspondientes (1-3 Gy) y, 30 minutos después, se analizó la formación de focos de $\mathrm{HH} 2 \mathrm{AX}$ y 53BP1 mediante microscopía confocal. A. Efecto del silenciamiento de VRK1 sobre la formación de focos de $\mathrm{yH} 2 \mathrm{AX}$ tras la inducción de daño génico con olaparib, IR o su combinación. B. Cuantificación del número de focos de $\mathrm{YH} 2 \mathrm{AX}$ en respuesta al daño génico provocado por el tratamiento con olaparib y/o IR en presencia 0 ausencia de VRK1. La significación estadística se calculó con el test de comparación múltiple de Dunn's. C. Efecto del silenciamiento de VRK1 sobre la formación de focos de 53BP1 tras la inducción de daño génico con olaparib, IR o su combinación. D. Cuantificación del número de focos de 53BP1 en respuesta al daño génico provocado por el tratamiento con olaparib y/o IR en presencia o ausencia de VRK1. La significación estadística se calculó con el test de comparación múltiple de Dunn's. E. Análisis de los niveles proteicos de VRK1 tras el silenciamiento génico. siCtrl: siC; siVRK1-02: siV. ns: no significativo; ${ }^{* *}, p<0,01 ;{ }^{* *}, p<0,001$.

\subsection{El efecto del silenciamiento de VRK1 sobre la respuesta al daño génico inducido por olaparib y/o IR es independiente de p53 y ATM en células sin suero $(0,5 \%)$}

VRK1 es un regulador conocido de p53 en respuesta al daño en el ADN. La fosforilación de la treonina 18 de p53 mediada por esta quinasa tras la inducción de daño génico impide su degradación y favorece su acumulación en la célula (147). Por esta razón, quisimos determinar si la respuesta al daño mediada por VRK1 era dependiente de p53. Con este objetivo, analizamos el número de focos de $\mathrm{\gamma H} 2 \mathrm{AX}$ y 53BP1 tras el silenciamiento de VRK1, la retirada del suero del medio de cultivo y el tratamiento con olaparib y/o IR en la línea celular H1299 (TP53 -/-) y vimos que se reducía notablemente (Figura 24), lo que nos indica que la ausencia de VRK1 interfiere en la respuesta al daño génico y no depende de p53. 


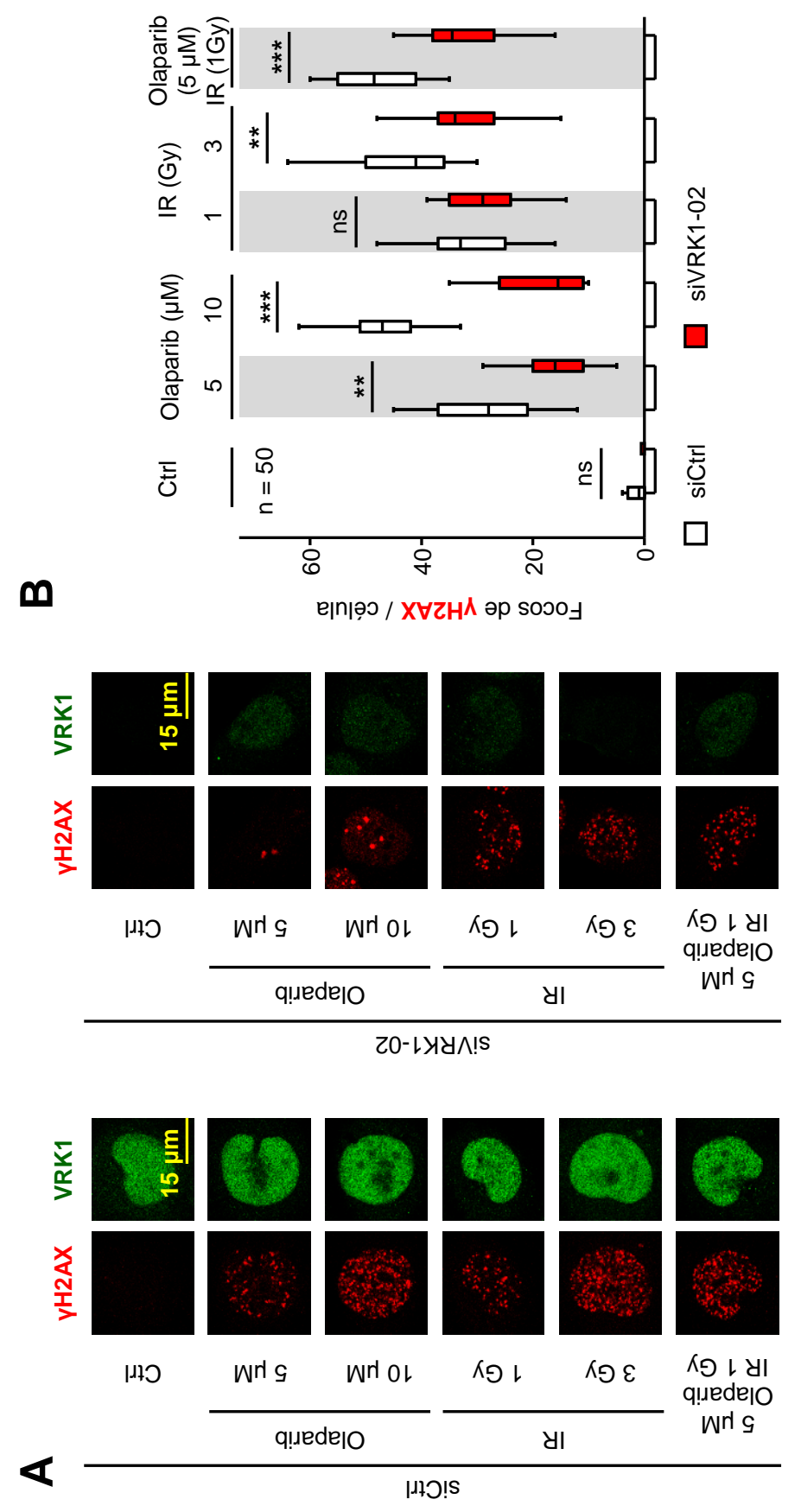



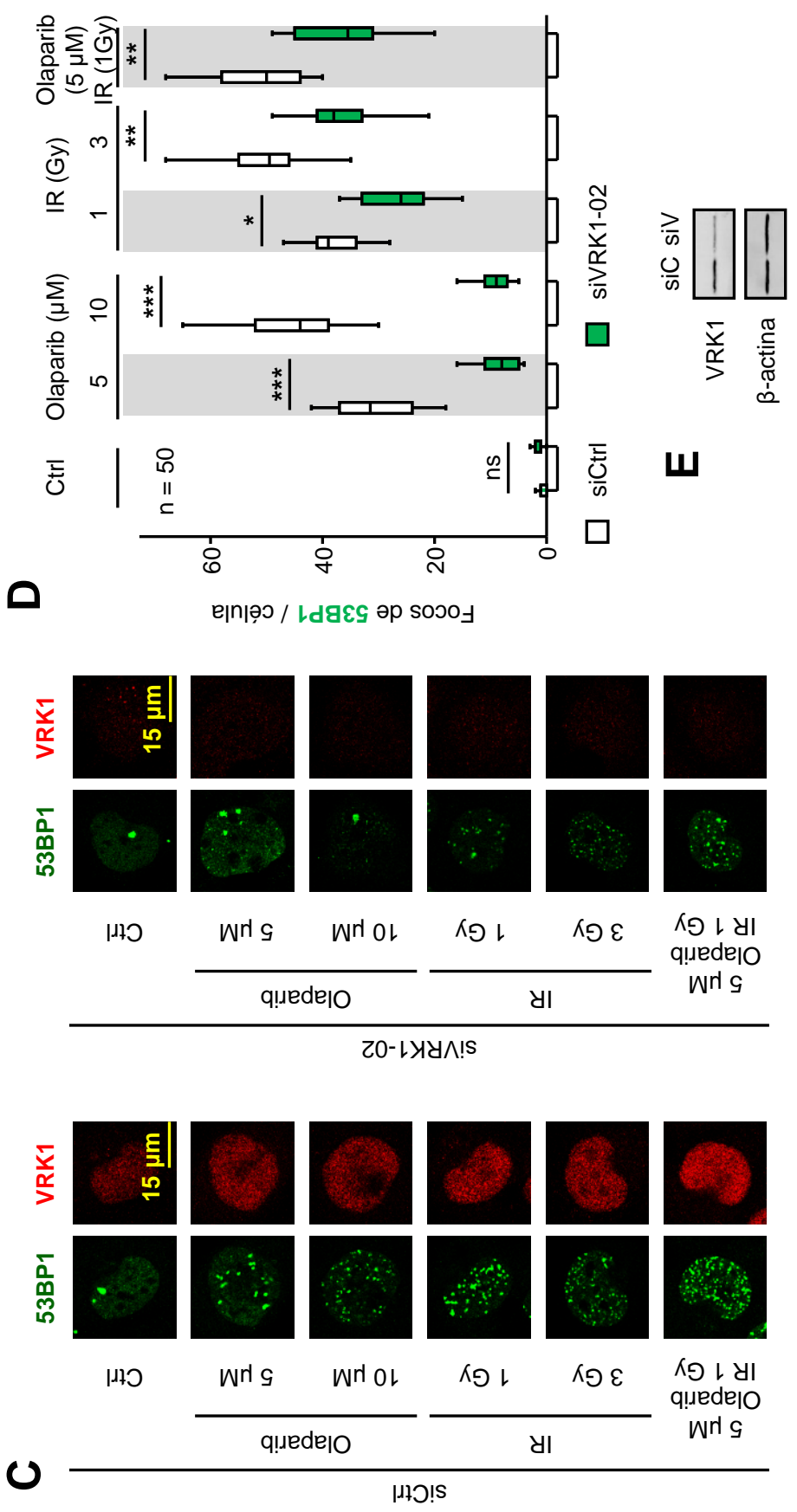
Figura 24: El silenciamiento de VRK1 interfiere en la formación de focos de $\mathrm{YH} 2 \mathrm{AX}$ y 53BP1 en respuesta al tratamiento con olaparib, IR o su combinación en células en reposo carentes de p53 (H1299). Se transfectaron estas células con 2 ARNi (siCtrl y siVRK1-02, 72 horas), se retiró el suero del medio de cultivo 24 horas después (48 horas, $0,5 \% \mathrm{FBS}$ ), se trataron las células correspondientes con olaparib (5-10 $\mu \mathrm{M})$ y/o se irradiaron (1-3 Gy) pasadas 24 horas. A continuación (30 minutos post-IR), se evaluó la formación de focos de $\mathrm{YH} 2 \mathrm{AX}$ y 53BP1 mediante microscopía confocal. A. Efecto del silenciamiento de VRK1 sobre la formación de focos de $\mathrm{YH} 2 \mathrm{AX}$ en respuesta a olaparib, IR o su combinación. B. Cuantificación del número de focos de $\mathrm{YH} 2 \mathrm{AX}$ tanto en presencia como en ausencia de VRK1 tras el tratamiento con olaparib e IR, por separado, o con su combinación. La significación estadística se calculó con el test de comparación múltiple de Dunn's. C. Efecto del silenciamiento de VRK1 sobre la formación de focos de 53BP1 tras la inducción de daño génico con olaparib y/o IR. D. Cuantificación del número de focos de 53BP1 en respuesta al daño génico provocado por el tratamiento con olaparib y/o IR en presencia o ausencia de VRK1. La significación estadística se calculó con el test de comparación múltiple de Dunn's. E. Comprobación del silenciamiento de VRK1 por western blot. siCtrl: siC; siVRK1-02: siV. ns: no significativo; ${ }^{*}, p<0,05 ;{ }^{* *}, p<0,01 ;{ }^{* * *}, p<0,001$.

A su vez, nos preguntamos qué efecto tendría el silenciamiento de VRK1 sobre la formación de focos de $\mathrm{YH} 2 \mathrm{AX}$ y 53BP1 en células carentes de ATM (HT144), otra de las quinasas celulares que fosforila a la histona $\mathrm{H} 2 \mathrm{AX}$ y a 53BP1 como consecuencia de la inducción de daño génico $(68,94,102)$. Para responder a esta cuestión, silenciamos la expresión génica de $V R K 1$, retiramos los factores mitogénicos presentes en el suero del medio de cultivo y tratamos las células con olaparib y/o IR, evaluando posteriormente la respuesta al daño a través de la formación de focos de $\mathrm{YH} 2 \mathrm{AX}$ y 53BP1, como en el caso anterior. Los resultados obtenidos fueron muy similares a los mostrados previamente en las líneas A549 y H1299 (Figuras 23 y 24, respectivamente), ya que la ausencia de VRK1 se tradujo también en estas células en una reducción significativa de los focos de reparación de yH2AX y 53BP1 (Figura 25), poniendo de manifiesto que la respuesta al daño en el ADN mediada por VRK1 es independiente de ATM. 

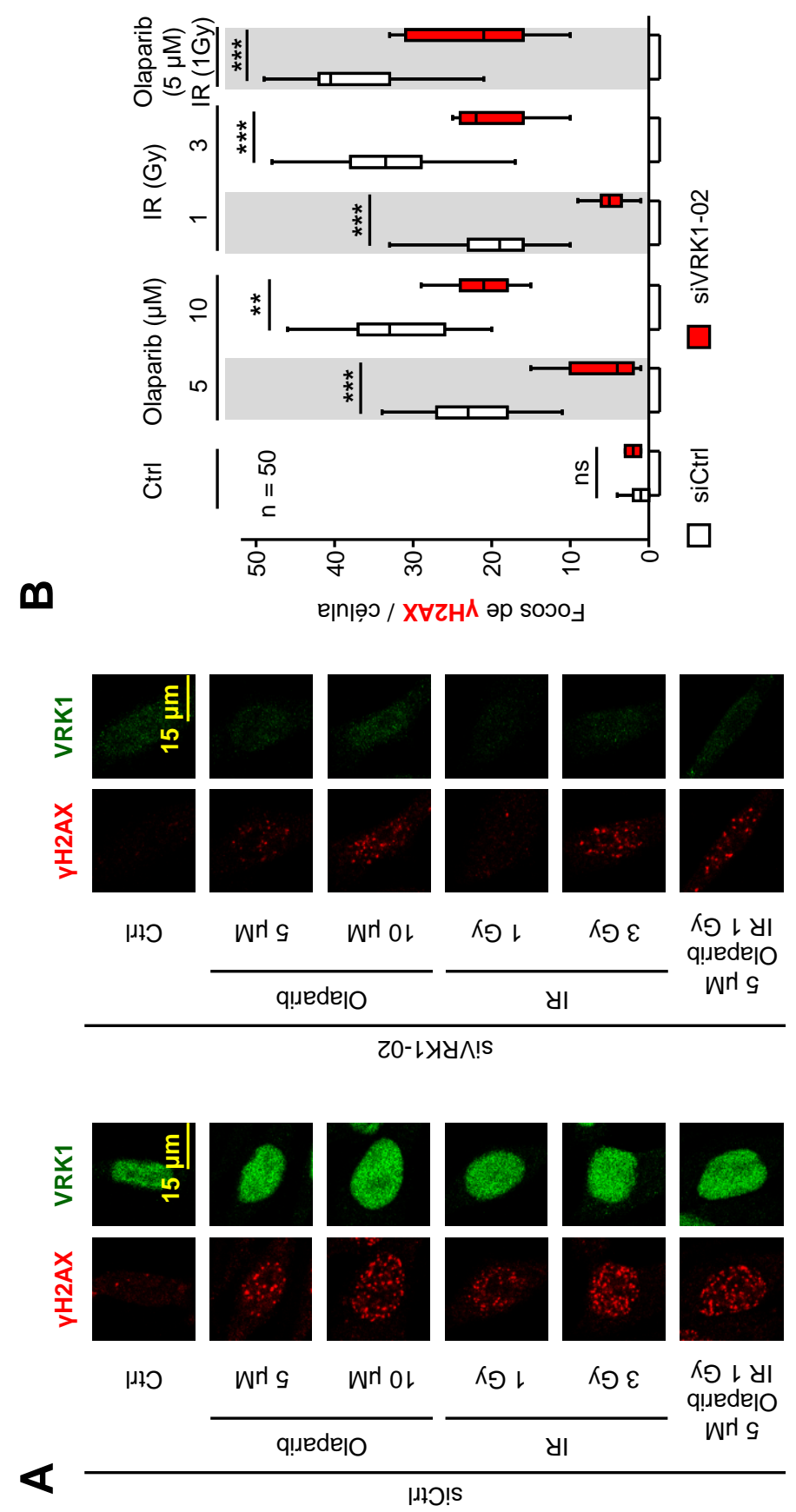

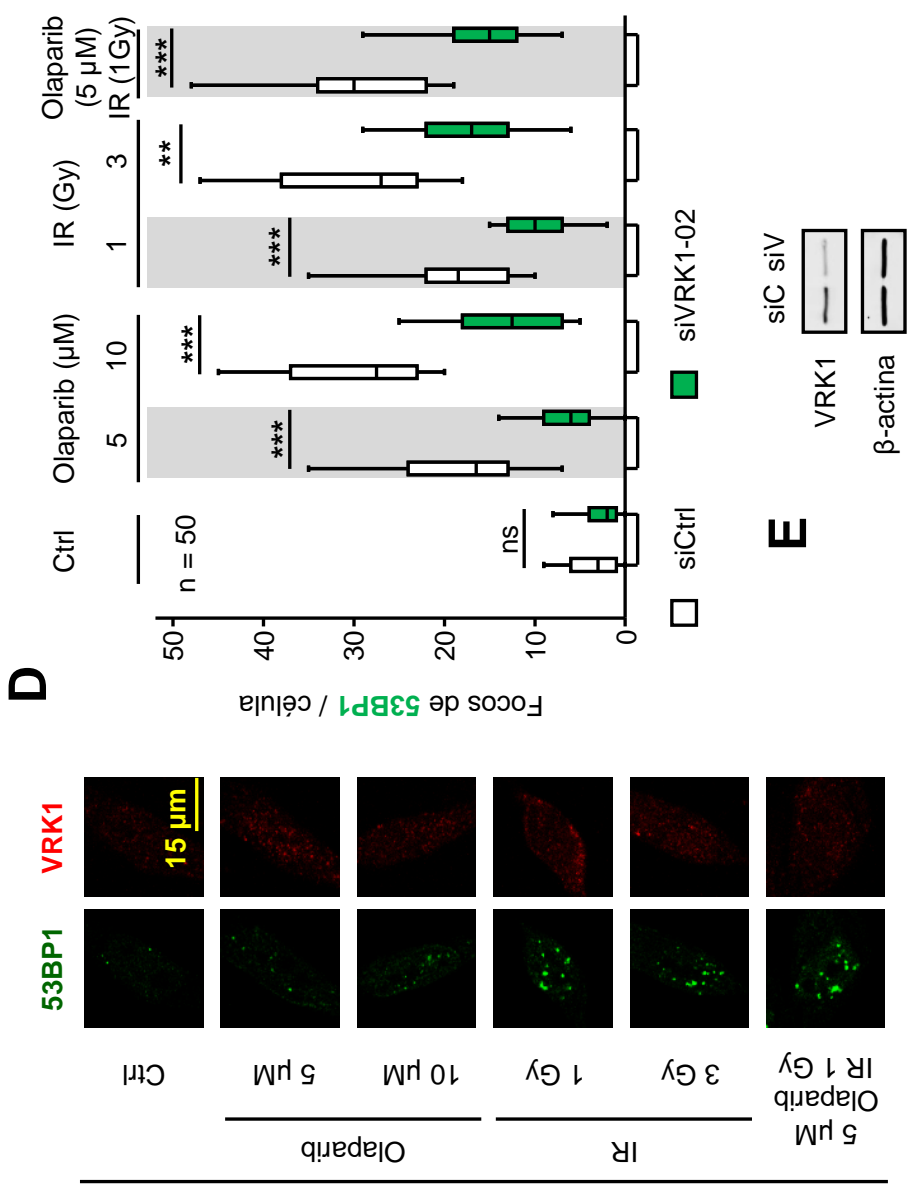

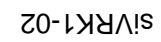

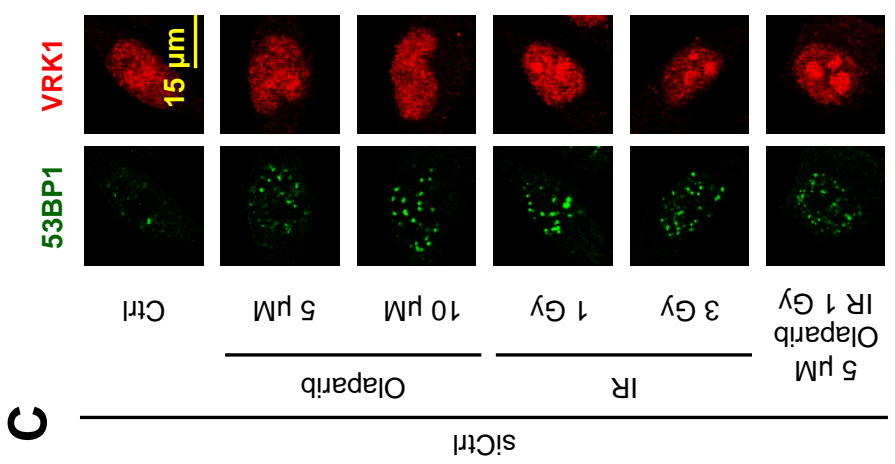


Figura 25: El efecto del silenciamiento de VRK1 sobre la formación de focos de yH2AX y 53BP1 en respuesta al tratamiento con olaparib, IR o su combinación es independiente de ATM en células sin suero (0,5\%). Tras silenciar la expresión génica de VRK1 (72 horas) y retirar el suero del medio de cultivo (48 horas) de la línea celular HT144 (ATM -/-), se trataron las células correspondientes con olaparib $(5-10 \mu \mathrm{M})$ y/o se irradiaron (1-3 Gy) 24 horas después. Pasados 30 minutos, se analizó la formación de focos de $\mathrm{yH} 2 \mathrm{AX}$ y 53BP1. A. Efecto del silenciamiento de $V R K 1$ sobre la formación de focos de $\mathrm{YH} 2 \mathrm{AX}$ en respuesta a olaparib, IR o su combinación. B. Cuantificación del número de focos de $\mathrm{yH} 2 \mathrm{AX}$ tanto en presencia como en ausencia de VRK1 tras el tratamiento con olaparib y/o IR. La significación estadística se calculó con el test de comparación múltiple de Dunn's. C. Efecto del silenciamiento de VRK1 sobre la formación de focos de 53BP1 tras la inducción de daño génico con olaparib, IR o su combinación. D. Cuantificación del número de focos de 53BP1 tras el tratamiento con olaparib y/o IR en presencia o ausencia de VRK1. La significación estadística se calculó con el test de comparación múltiple de Dunn's. E. Análisis de los niveles proteicos de VRK1 tras el silenciamiento génico. siCtrl: siC; siVRK1-02: siV. ns: no significativo; ${ }^{* *}, p<0,01 ;{ }^{* * *}, p<0,001$.

\subsection{La inhibición de ATM mimetiza el efecto del silenciamiento de VRK1 sobre la formación de focos de yH2AX y 53BP1 en respuesta a olaparib}

Estudios anteriores demostraron que VRK1 precede a la quinasa ATM en la respuesta al daño génico $(85,86,101)$. En base a estos datos, el siguiente objetivo que nos planteamos fue determinar si la inhibición de ATM tenía el mismo efecto que el silenciamiento de VRK1 sobre la formación de focos de $\mathrm{YH} 2 \mathrm{AX}$ y 53BP1. Para llevarlo a cabo, preincubamos las células A549 con KU55933, un inhibidor comercial de ATM, durante 3 horas antes de añadir el olaparib (24 horas), y, a continuación, analizamos la formación de focos de $\mathrm{YH} 2 \mathrm{AX}$ y 53BP1. Como cabía esperar, tanto la inhibición de ATM como el silenciamiento de VRK1 alteraban la respuesta al daño en el ADN, ya que el número de focos de $\mathrm{YH} 2 \mathrm{AX}$ y 53BP1 disminuyó considerablemente en ambos casos (Figura 26). 

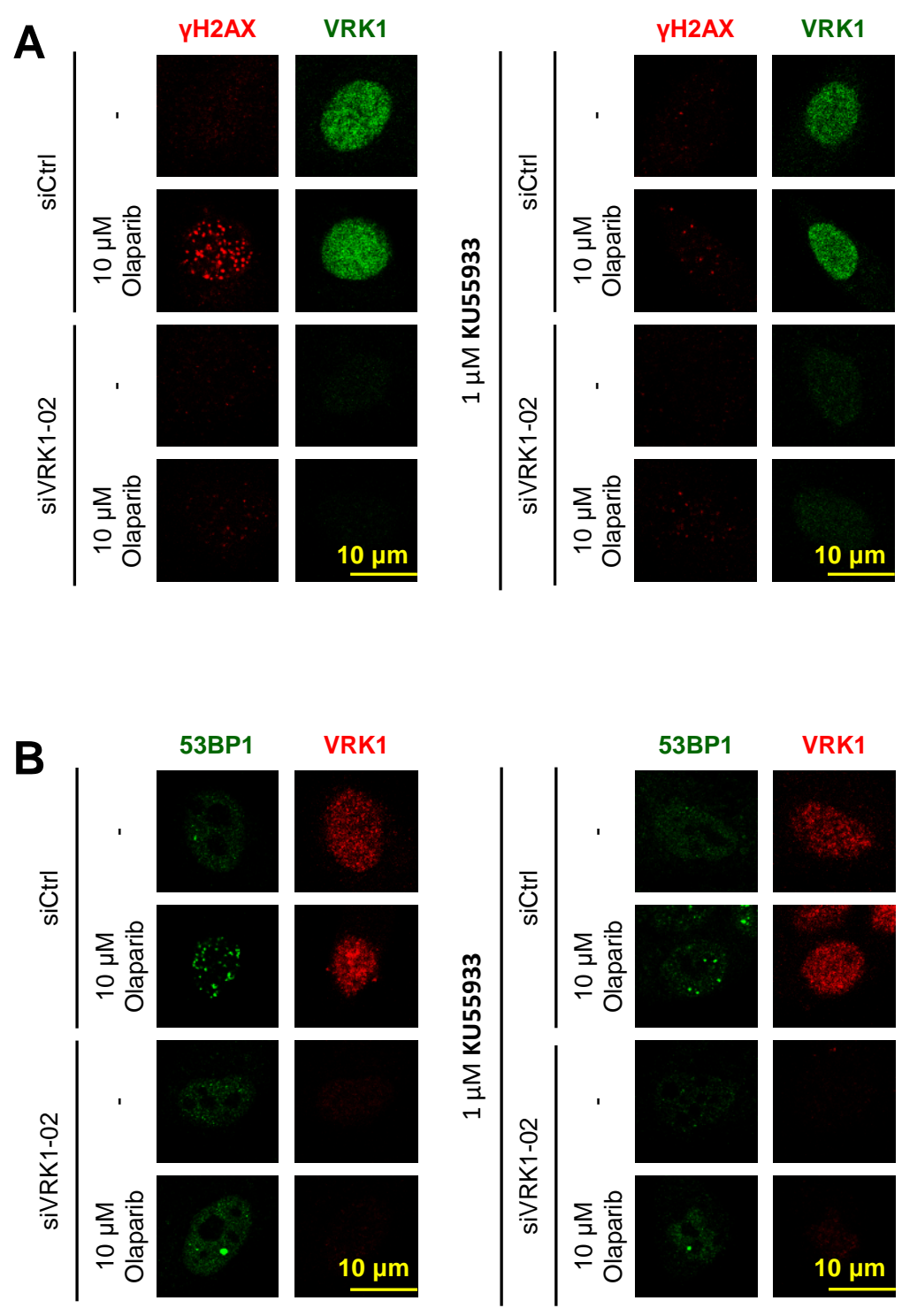

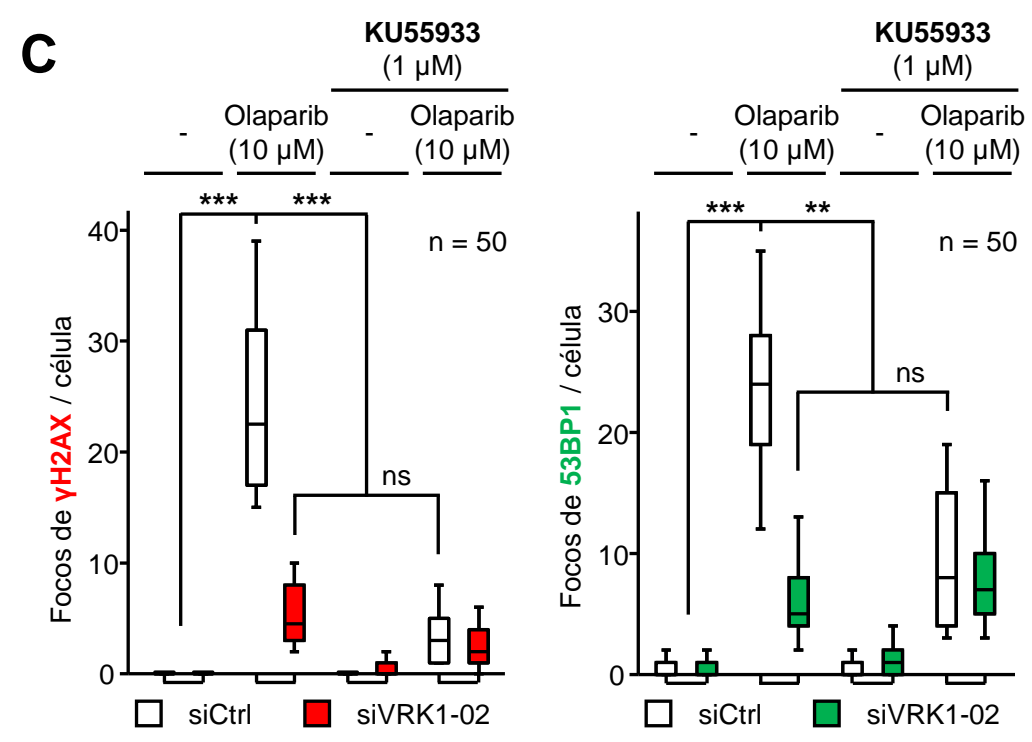

D

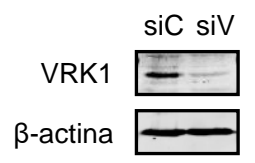

Figura 26: La inhibición de ATM mimetiza el efecto del silenciamiento de VRK1 sobre la formación de focos de YH2AX y 53BP1. Se transfectaron estas células con 2 ARNi (siCtrl y siVRK1-02, 72 horas) y se retiró el suero del medio de cultivo 24 horas después (48 horas, 0,5\% FBS). Tres horas antes de tratar las células correspondientes con olaparib (10 $\mu \mathrm{M}, 24$ horas), se preincubaron con $1 \mu \mathrm{M}$ de KU55933. Posteriormente, se evaluó la formación de focos de $\mathrm{YH} 2 \mathrm{AX}$ y 53BP1 asociados al tratamiento con olaparib en ausencia de VRK1 y/o tras la inhibición de ATM mediante microscopía confocal. A. Formación de focos de $\mathrm{yH} 2 \mathrm{AX}$ en respuesta a olaparib tras la inhibición de ATM y/o el silenciamiento de VRK1. B. Formación de focos de 53BP1 en respuesta al tratamiento con olaparib tras la inhibición de ATM y el silenciamiento de VRK1. C. Cuantificación del número de focos de $\mathrm{YH} 2 \mathrm{AX}$ y 53BP1 inducidos por olaparib en presencia o ausencia de VRK1 y/o tras inhibir a la quinasa ATM. La significación estadística se calculó con el test de comparación múltiple de Dunn's. D. Comprobación del silenciamiento de VRK1 por western blot. siCtrl: siC; siVRK1-02: siV. ns: no significativo; ${ }^{* *}, p<0,01 ;{ }^{* *}, p<0,001$.

\subsection{El silenciamiento de VRK1, pero no la inhibición de ATM, interfiere en la acetilación de la H4K16 asociada al tratamiento con olaparib}

La respuesta al daño génico inducido por olaparib implica la relajación local de la cromatina y se asocia a la acetilación de histonas como la H4K16ac. Anteriormente habíamos demostrado que esta acetilación es susceptible al silenciamiento de VRK1 asociada al daño génico, por lo que quisimos determinar si dependía o no de ATM. Con este fin, utilizamos dos enfoques distintos. El primero de ellos fue estudiar la 
acetilación de la H4K16 en el contexto de células que carecen de ATM (HT144); el segundo, caracterizar los cambios en dicha acetilación en una línea ATM +/+ (A549) en la que se inhibió específicamente esta quinasa con KU55933. En el caso de las células HT144 (ATM -/-) (Figura 27), la acetilación de la H4K16 aumentó sustancialmente en respuesta al tratamiento con olaparib, pero se vio afectado de manera significativa al silenciar la quinasa VRK1. Por su parte, las células A549 tratadas con el inhibidor de ATM no experimentaron ningún cambio en los niveles de acetilación de la H4K16 con respecto a las células control tras el tratamiento con olaparib, aunque se redujeron notablemente en ausencia de VRK1 (Figura 28). Ambos resultados pusieron de manifiesto que el efecto de VRK1 sobre la acetilación de la H4K16 es independiente de ATM.

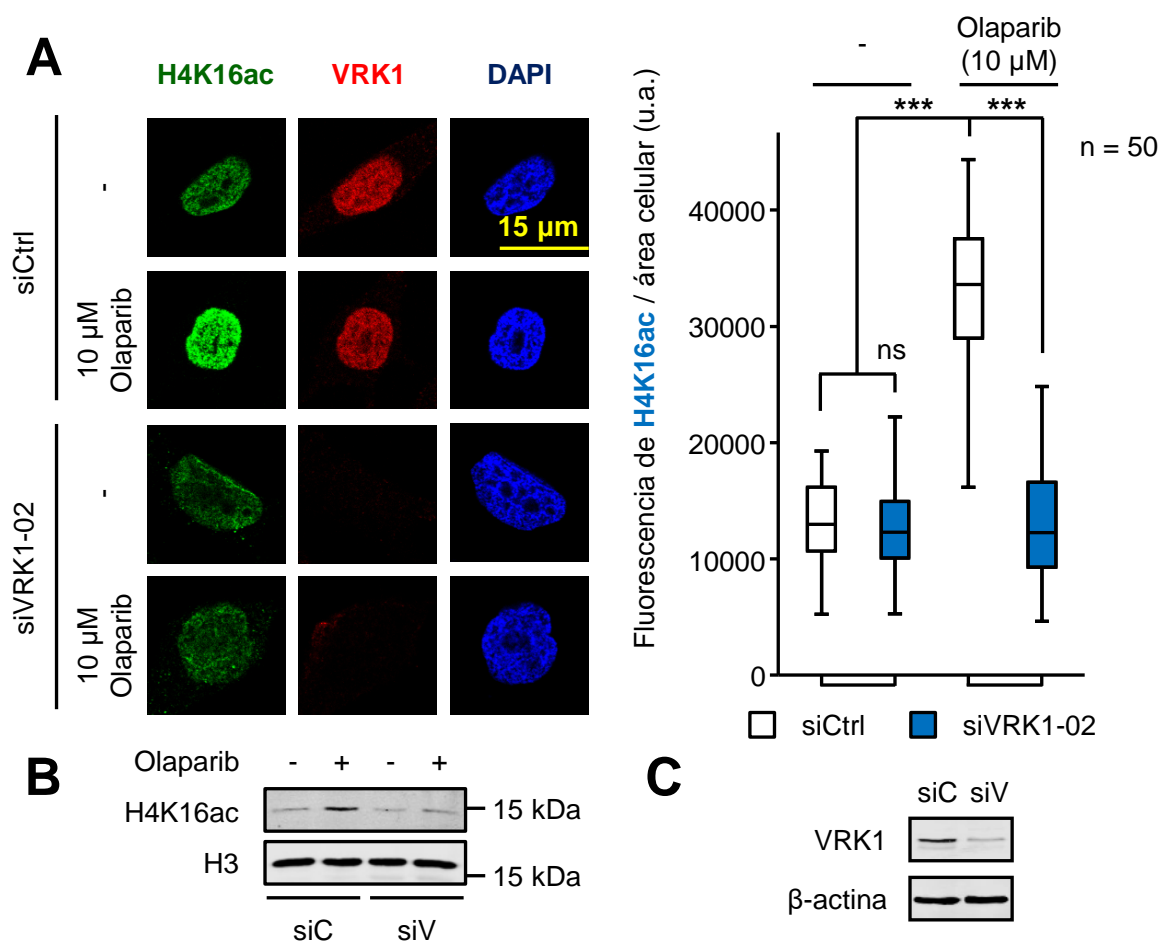

Figura 27: La ausencia de VRK1 conlleva una reducción significativa de los niveles de la H4K16ac en las células HT144 (ATM -/-). Se silenció la expresión génica de VRK1 durante 72 horas y se retiró el suero del medio de cultivo 24 horas después (48 horas, 0,5\% FBS). A continuación, se trataron las células correspondientes con olaparib (10 $\mu \mathrm{M}, 24$ horas) y se analizaron los niveles de la H4K16ac mediante microscopía confocal y western blot. A. Acetilación de la H4K16 en respuesta al tratamiento con olaparib en presencia o ausencia de VRK1, y cuantificación de los niveles de dicha acetilación. La significación estadística se calculó con el test de comparación múltiple de Dunn's. B. Cambios en los niveles de la H4K16ac evaluados por western blot a partir de extractos enriquecidos en histonas. C. Análisis de los niveles proteicos de VRK1 tras el silenciamiento génico. siCtrl: siC; siVRK1-02: siV. ns: no significativo; ${ }^{* \star *}, p<0,001$. 
$\mathbf{A}$

A
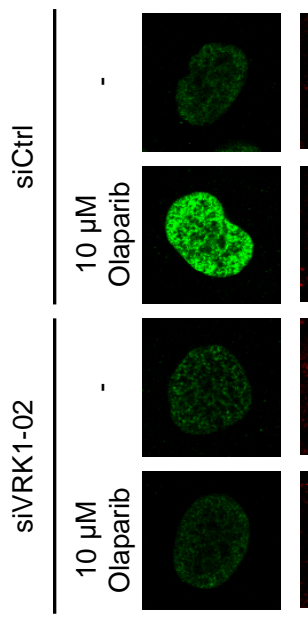

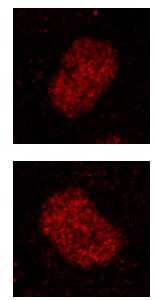

$10 \mu \mathrm{m}$
H4K16ac

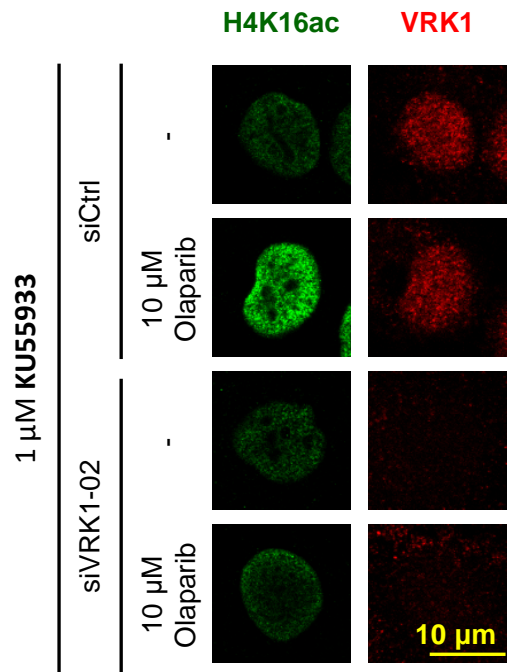

\section{B}
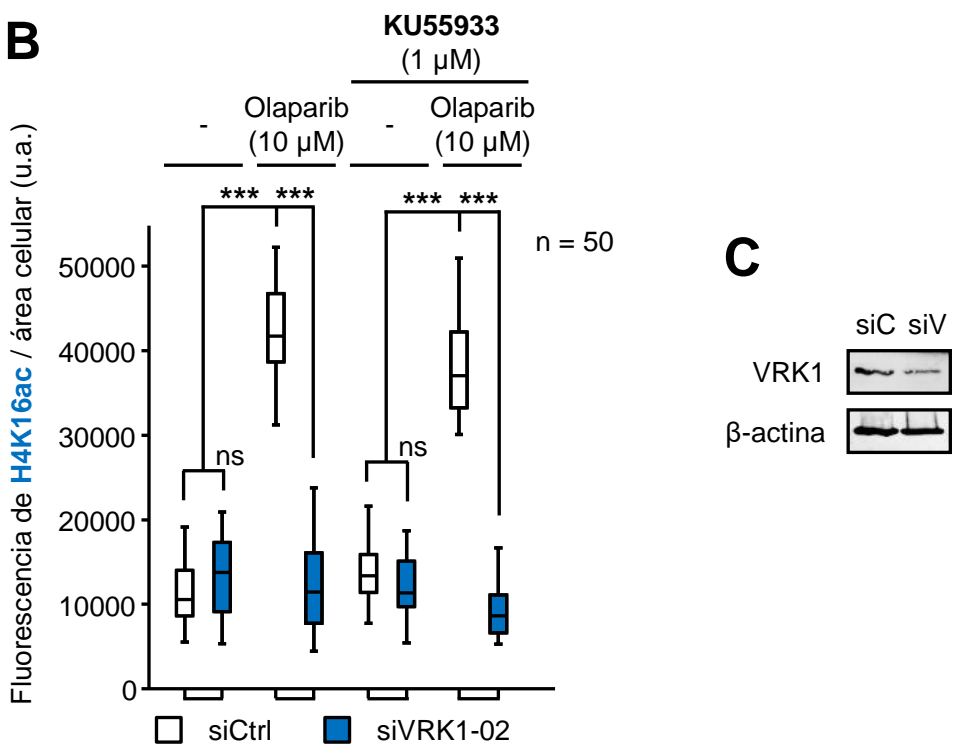

Figura 28: La inhibición de ATM no interfiere en la acetilación de la H4K16 en las células A549. Se transfectaron estas células con 2 ARNi (siCtrl y siVRK1-02, 72 horas) y se retiró el suero del medio de cultivo 24 horas después (48 horas, 0,5\% FBS). Tres horas antes de tratar las células con olaparib (10 $\mathrm{M}, 24$ horas), se preincubaron con el inhibidor de ATM (KU55933, 1 $\mu \mathrm{M}) \mathrm{y}$, se evaluaron los niveles de la H4K16ac mediante microscopía confocal. A. Efecto del silenciamiento de VRK1 y/o del inhibidor KU55933 sobre la acetilación de la H4K16 en respuesta al tratamiento con olaparib. B. Cuantificación de los niveles de la H4K16ac tras el tratamiento con olaparib y/o el inhibidor de ATM en presencia o ausencia de VRK1. La significación estadística se calculó con el test de comparación múltiple de Dunn's. C. Comprobación del silenciamiento de VRK1 por western blot. siCtrl: siC; siVRK1-02: siV. ns: no significativo; ${ }^{* * *}$, $p<0,001$. 


\section{EFECTO DEL INHIBIDOR CHAETOCIN EN LA REGULACIÓN DEL CICLO CELULAR Y LA RESPUESTA AL DAÑO EN EL ADN}

\subsection{Los cambios en la metilación de la cromatina alteran el perfil de ciclo celular sin modificar la viabilidad}

La cromatina es una estructura dinámica sujeta a numerosos cambios asociados a procesos celulares que afectan al $A D N$, como la replicación, la transcripción o la respuesta al daño génico, que implican alteraciones en el patrón de modificaciones covalentes en las histonas. Con el objetivo de estudiar parte de estas alteraciones, concretamente las que afectan a la metilación, en distintos contextos celulares, utilizamos un enfoque basado en el tratamiento con inhibidores de metiltransferasas (chaetocin) y de demetilasas (JMJD2 inhibitor o JMJD2i). El inhibidor chaetocin es una micotoxina presente en especies del género Chaetomium y pertenece a la clase de las 3-6 epiditio-dicetopiperacinas (227). Por su parte, el JMJD2i o 5-carboxi-8hidroxiquinolina es un inhibidor específico de la subfamilia de demetilasas JMJD2, que consta de 6 miembros (JMJD2A-F) (228).

Lo primero que quisimos determinar fue la capacidad de ambos compuestos para inhibir la metilación y demetilación de un resido conocido, la trimetilación de la lisina 9 de la histona H3 (H3K9me3), en la línea celular U2OS. Utilizando concentraciones de $100 \mathrm{nM}$ de chaetocin y $100 \mu \mathrm{M}$ de JMJD2i, observamos una reducción significativa de los niveles de $\mathrm{H} 3 \mathrm{~K} 9 \mathrm{me} 3$ tras el tratamiento con chaetocin, y un aumento considerable de la trimetilación de la H3K9 en respuesta al inhibidor JMJD2i (Figura 29).

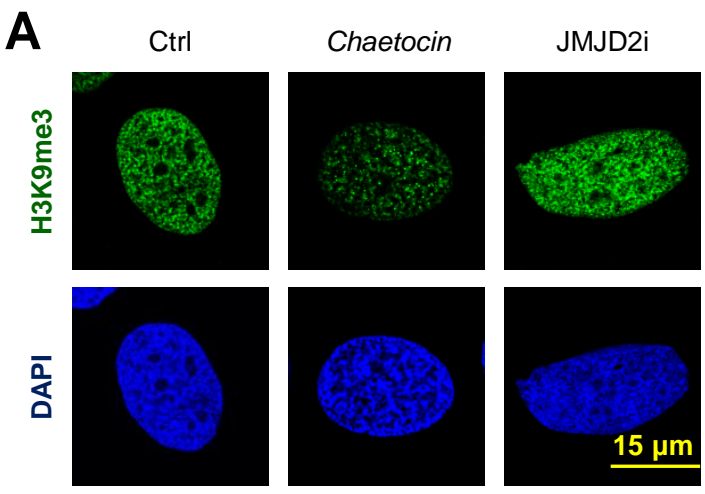




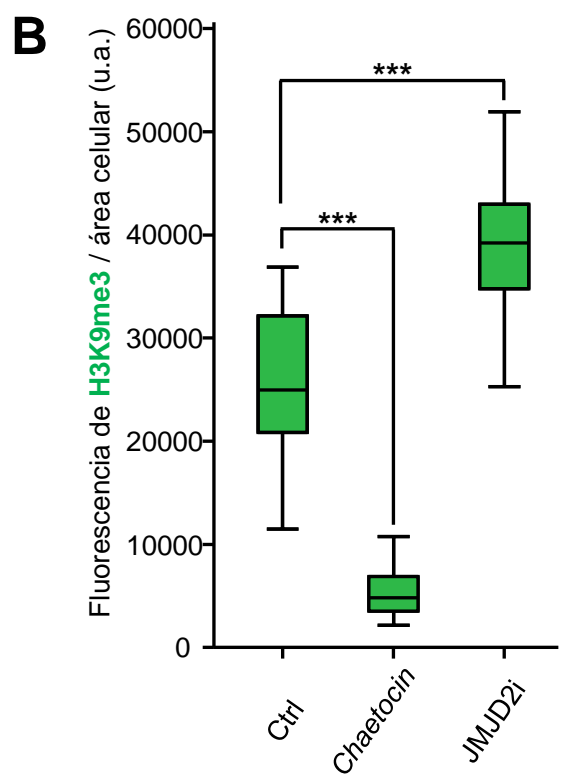

Figura 29: Cambios en la trimetilación de la H3K9 tras el tratamiento con chaetocin o JMJD2i. Tras retirar el suero del medio de cultivo (48 horas, 0,5\% FBS), se trataron las células U2OS con $100 \mathrm{nM}$ de chaetocin o $100 \mu \mathrm{M}$ de JMJD2i durante 24 horas. Posteriormente, se analizaron los niveles de la H3K9me3 mediante microscopía confocal. A. Trimetilación de la H3K9 en presencia de chaetocin o JMJD2i. B. Cuantificación de los niveles de H3K9me3 tras el tratamiento con chaetocin o JMJD2i. La significación estadística se analizó con el test de la $U$ de Mann-Whitney, comparando por separado cada uno de los tratamientos con el control. ${ }^{* * *}$, $\mathrm{p}<0,001$.

A continuación, nos propusimos caracterizar el efecto de estos inhibidores sobre el ciclo y la viabilidad celular, ya que estudios previos mostraban que el inhibidor chaetocin inducía la parada del ciclo celular en G2/M y promovía la apoptosis (229). En este caso, sincronizamos las células U2OS en las fases G2/M del ciclo con nocodazol y las tratamos con chaetocin o JMJD2i. Seguidamente, analizamos el perfil de ciclo celular y la viabilidad mediante citometría de flujo. En respuesta al tratamiento con chaetocin, las células U2OS no eran capaces de progresar a través del ciclo celular, quedando atrapadas en las fases G2/M (Figura 30.A y C). Por contra, el inhibidor de la subfamilia JMJD2 mostraba un perfil similar al de las células control, pero con un incremento significativo del porcentaje de células en G0/G1 (Figura 30.A y C). Ahora bien, curiosamente, ninguno de los dos inhibidores mostró diferencias significativas en la viabilidad celular con respecto a las células control (Figura 30.B y C). 


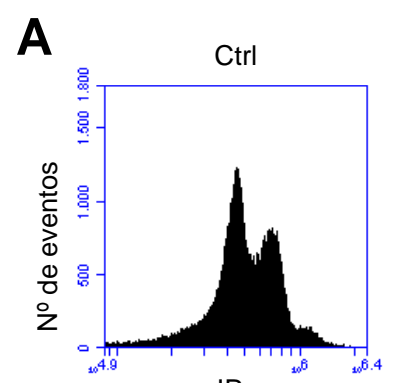

B

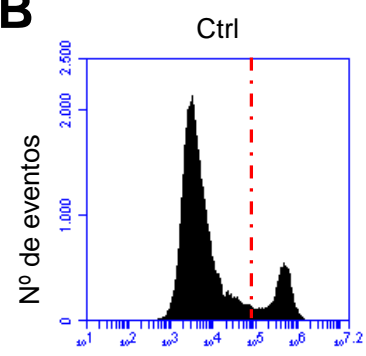

C

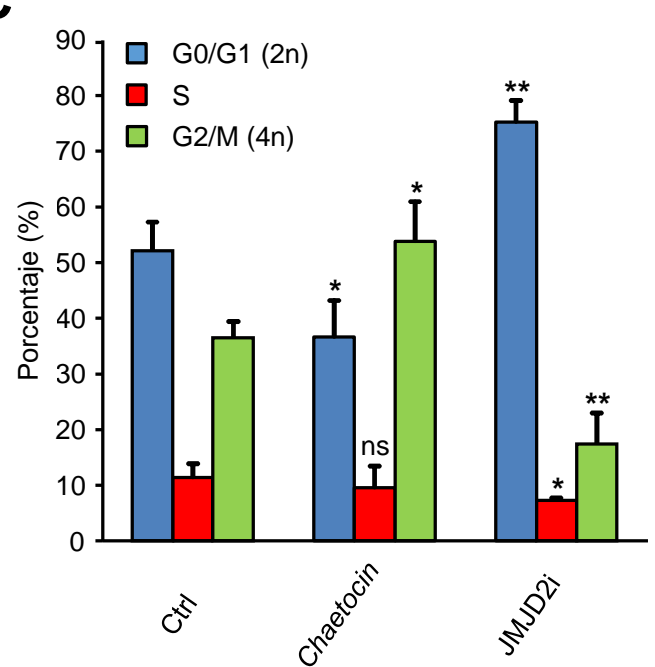

IP

IP
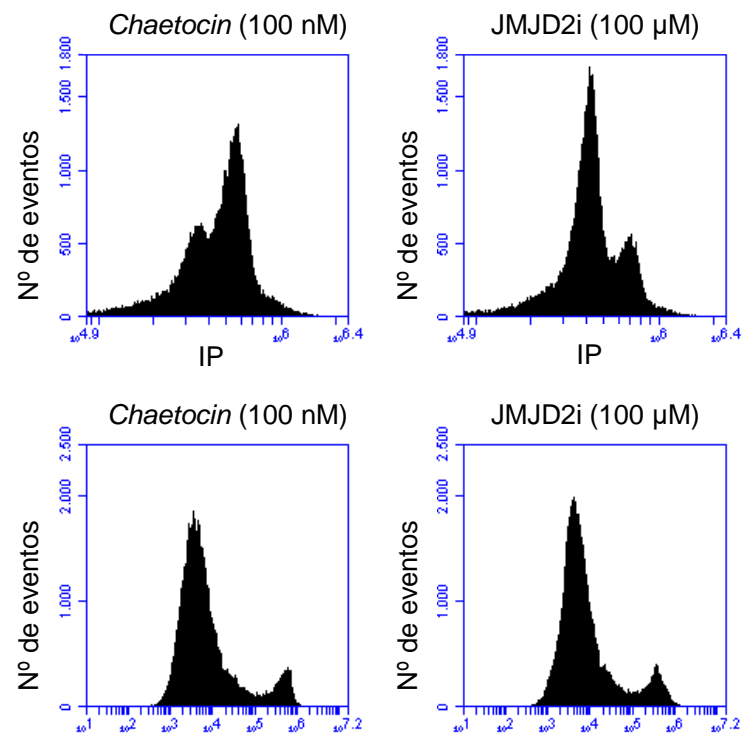

IP

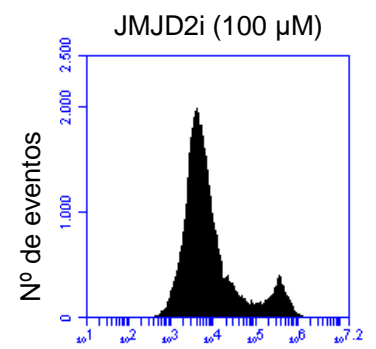

IP

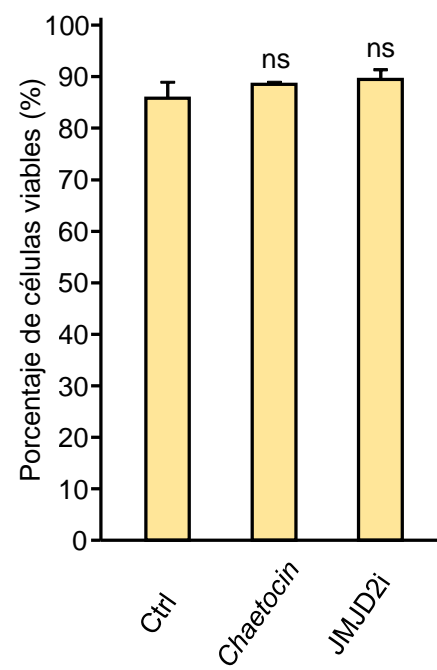

Figura 30: El inhibidor de metiltransferasas chaetocin y el de demetilasas JMJD2i modifican el perfil de ciclo de las células U2OS sin alterar su viabilidad. Se trataron estas células con nocodazol durante toda la noche para sincronizarlas en las fases G2/M del ciclo, y antes de retirar este compuesto del medio, se preincubaron durante 3 horas con chaetocin (100 nM) o JMJD2i $(100 \mu \mathrm{M})$. Posteriormente, se eliminó el nocodazol del medio y se añadió medio al $0,5 \%$ de suero con cada uno de los inhibidores (a excepción del punto control) durante 24 horas. Finalmente se evaluó la viabilidad celular y el perfil de ciclo mediante citometría de flujo. A. Perfil de ciclo celular tras el tratamiento con los inhibidores de metiltransferasas y demetilasas. B. Estudio de la viabilidad celular en respuesta a chaetocin y JMJD2i. C. Análisis del perfil de ciclo celular y del porcentaje de células viables como consecuencia del tratamiento con chaetocin y JMJD2i. Los experimentos de viabilidad y ciclo celular se realizaron por triplicado y la significación estadística se calculó mediante la comparación de ambos tratamientos con el control utilizando la $t$ de Student. ns: no significativo; *, $p<0,05 ;{ }^{* *}, p<0,01$. 


\subsection{El inhibidor chaetocin es capaz de inducir daño en el ADN por sí mismo, pero no muestra efectos sinérgicos con la radiación ionizante.}

Otro de los efectos asociados al inhibidor chaetocin, junto con la regulación del ciclo celular, es la capacidad que tiene para inducir estrés oxidativo (230). Esto nos llevó a pensar que este inhibidor causaría daño en el ADN y podría colaborar con otras fuentes de daño oxidativo como la radiación ionizante. Para corroborar esta hipótesis, tratamos las células U2OS con dosis crecientes de chaetocin durante 24 horas y, posteriormente, las irradiamos (1-3 Gy). Pasados 30 minutos, analizamos la formación de focos de $\mathrm{yH} 2 \mathrm{AX}$ en respuesta al tratamiento con chaetocin, IR o su combinación. Los resultados obtenidos demostraron que el inhibidor chaetocin, independientemente de la concentración empleada, aumentaba de manera significativa el número de focos de reparación con respecto al control, pero su efecto era menor que el de las dosis de radiación empleadas. Además, la combinación de este inhibidor (50 nM) con IR (1 Gy) no se tradujo en un incremento de la cantidad de focos de $\mathrm{yH} 2 \mathrm{AX}$ respecto al tratamiento con 1 Gy de IR (Figura 31).
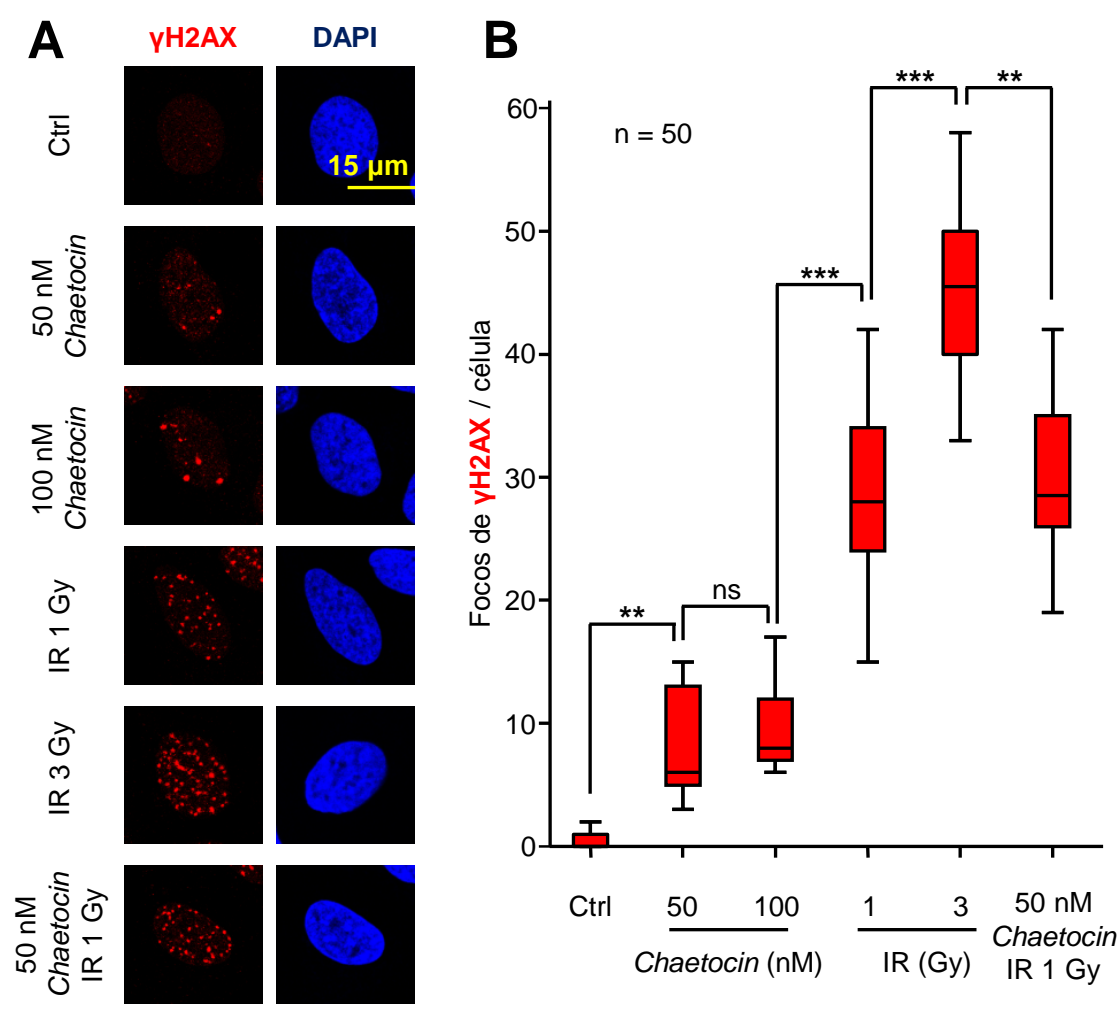
Figura 31: El inhibidor chaetocin induce daño en el ADN, pero no muestra un efecto sinérgico sobre la formación de focos de yH2AX al combinarlo con IR. Se retiró el suero del medio de cultivo de las células U2OS durante 48 horas (0,5\% FBS) y se trataron con chaetocin (50-100 nM, 24 horas). Pasadas las 48 horas sin suero y las 24 de tratamiento con el inhibidor, se irradiaron (1-3 Gy) y, 30 minutos después, se analizó la formación de focos de yH2AX por microscopía confocal. A. Formación de focos de $\mathrm{yH} 2 \mathrm{AX}$ en respuesta al tratamiento con chaetocin y/o IR. B. Cuantificación del número de focos de $\mathrm{yH} 2 \mathrm{AX}$ tras la inducción de daño génico con chaetocin, IR o su combinación. La significación estadística se calculó utilizando el test de comparación múltiple de Dunn's. ns: no significativo; ${ }^{* *}, p<0,01 ;{ }^{* *}, p<0,001$.

\subsection{La inhibición de la metilación asociada al tratamiento con chaetocin impide la correcta formación de focos de 53BP1 tras la inducción de daño con IR}

En vista de los resultados obtenidos con $\mathrm{yH} 2 \mathrm{AX}$, un marcador de respuesta temprana, nos preguntamos cuál sería el efecto del inhibidor chaetocin sobre el reclutamiento de proteínas de reparación implicadas en una ruta concreta, como es el caso de 53BP1, utilizando como fuente de daño distintas dosis de radiación ionizante (0,5-1-3 Gy). Tras 24 horas de tratamiento con este inhibidor de metiltransferasas y 30 minutos después de irradiar las células, analizamos la formación de focos de $\mathrm{YH} 2 \mathrm{AX}$ y 53BP1 en la línea celular U2OS. Para nuestra sorpresa, el incremento del número de focos de $\mathrm{yH} 2 \mathrm{AX}$ asociado a dosis crecientes de IR en presencia del inhibidor chaetocin no iba acompañado de la acumulación de 53BP1 en las regiones del ADN dañadas (Figura 32.A y B).

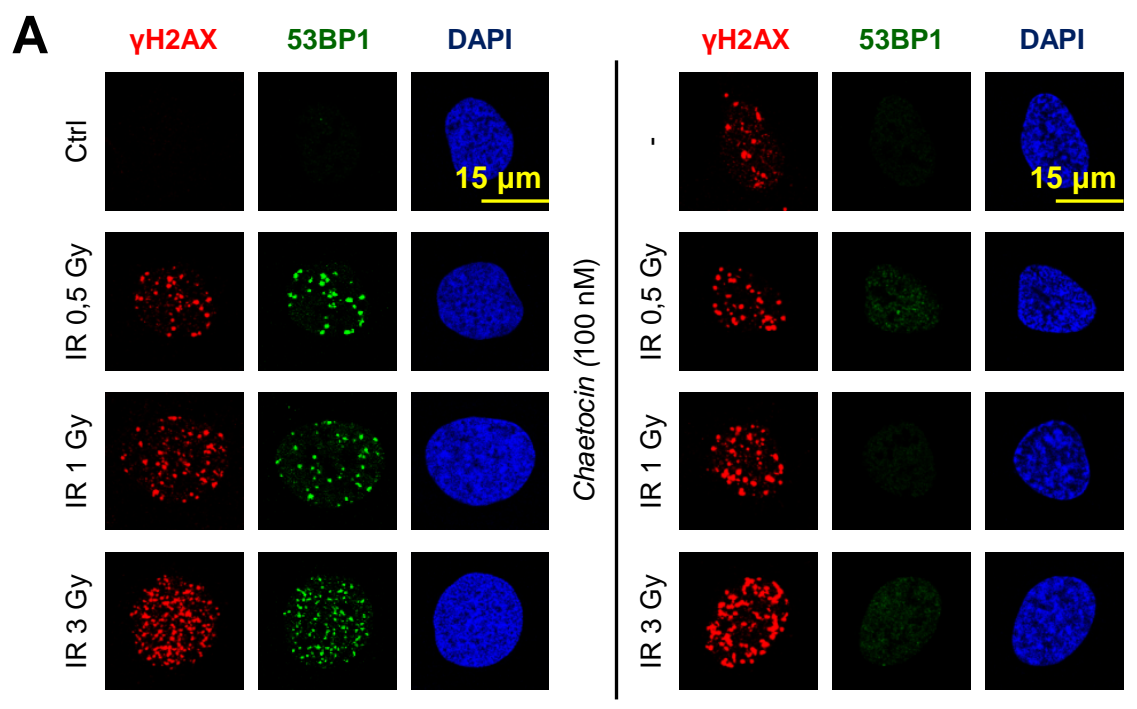



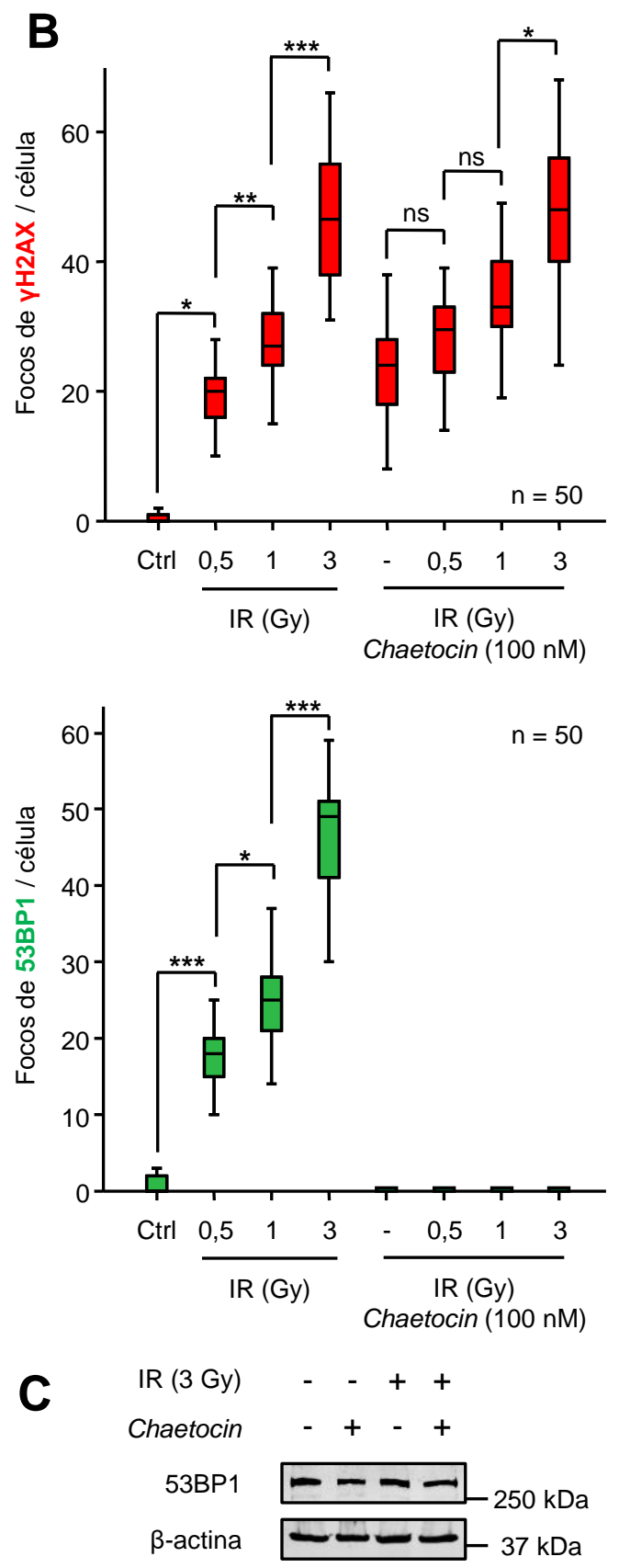
Figura 32: El inhibidor chaetocin impide la correcta formación de focos de 53BP1 tras la inducción de daño con IR sin modificar sus niveles proteicos. Tras retirar el suero del medio de cultivo de las células U2OS (48 horas, 0,5\% FBS) e incubarlas con 100 nM de chaetocin (24 horas), se irradiaron (0,5-1-3 Gy) y, pasados 30 minutos, se evaluó la formación de focos de YH2AX y 53BP1 mediante microscopía confocal. A. Focos de $\mathrm{YH} 2 \mathrm{AX}$ y 53BP1 en respuesta al tratamiento con IR y/o chaetocin. B. Cuantificación del número de focos de $\mathrm{YH} 2 \mathrm{AX}$ y $53 \mathrm{BP} 1$ en presencia o ausencia de chaetocin tras inducir daño génico con IR. La significación estadística se calculó utilizando el test de comparación múltiple de Dunn's. C. Western blot en el que se comparan los niveles proteicos de 53BP1 en respuesta al tratamiento con chaetocin y/o IR. ns: no significativo; ${ }^{*}, p<0,05 ;{ }^{* *}, p<0,01 ;{ }^{* * *}, p<0,001$.

Estos datos nos hicieron pensar que quizá el inhibidor chaetocin estuviese alterando la expresión de 53BP1 o promoviendo su degradación, por lo que analizamos los niveles proteicos de esta proteína mediante western blot. Al ver que estos niveles no se modificaban en presencia de chaetocin y/o IR (Figura 32.C), supusimos que este inhibidor interfería en el reclutamiento y la formación de focos de 53BP1.

A continuación, quisimos comprobar el efecto del inhibidor de demetilasas (JMJD2i) sobre la formación de focos de 53BP1 en células U2OS. En este caso, tratamos estas células durante 24 horas con el inhibidor de la subfamilia JMJD2 $(100 \mu \mathrm{M})$ y, a continuación, las irradiamos (0,5-1-3 Gy). A diferencia de lo que ocurría con el inhibidor chaetocin, tanto el número de focos de $\mathrm{yH} 2 \mathrm{AX}$ como el de 53BP1 aumentaban de manera dosis-dependiente en presencia de JMJD2i (Figura 33), lo que demuestra que la metilación es necesaria para el reclutamiento de 53BP1.

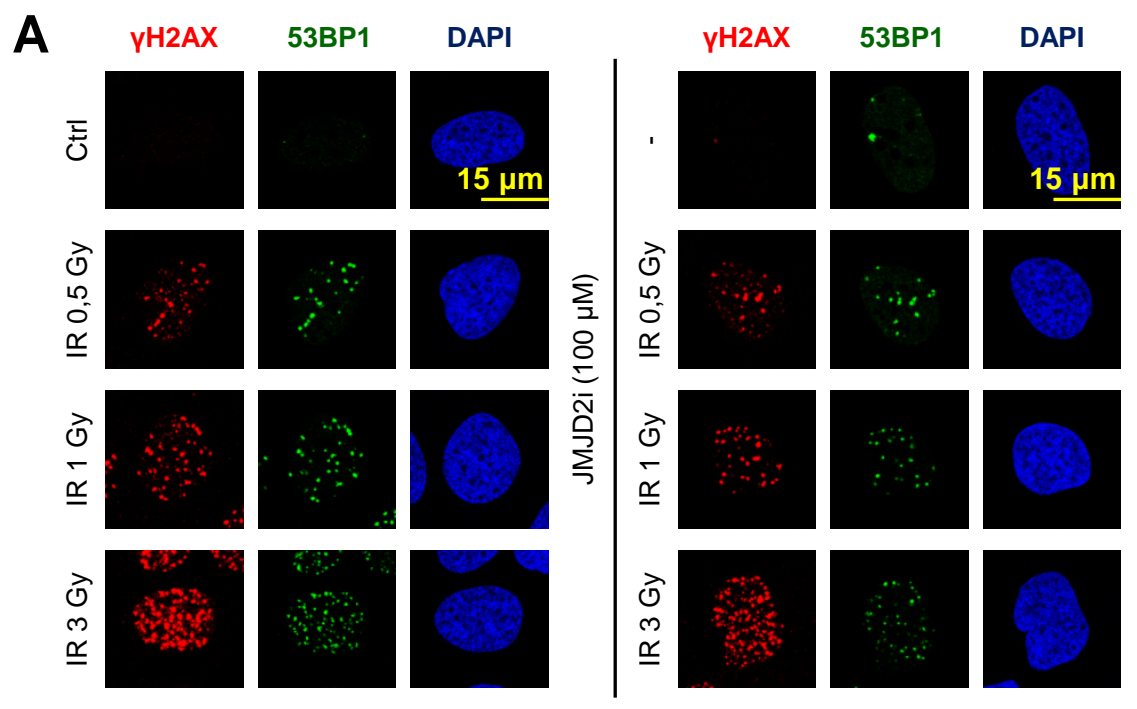



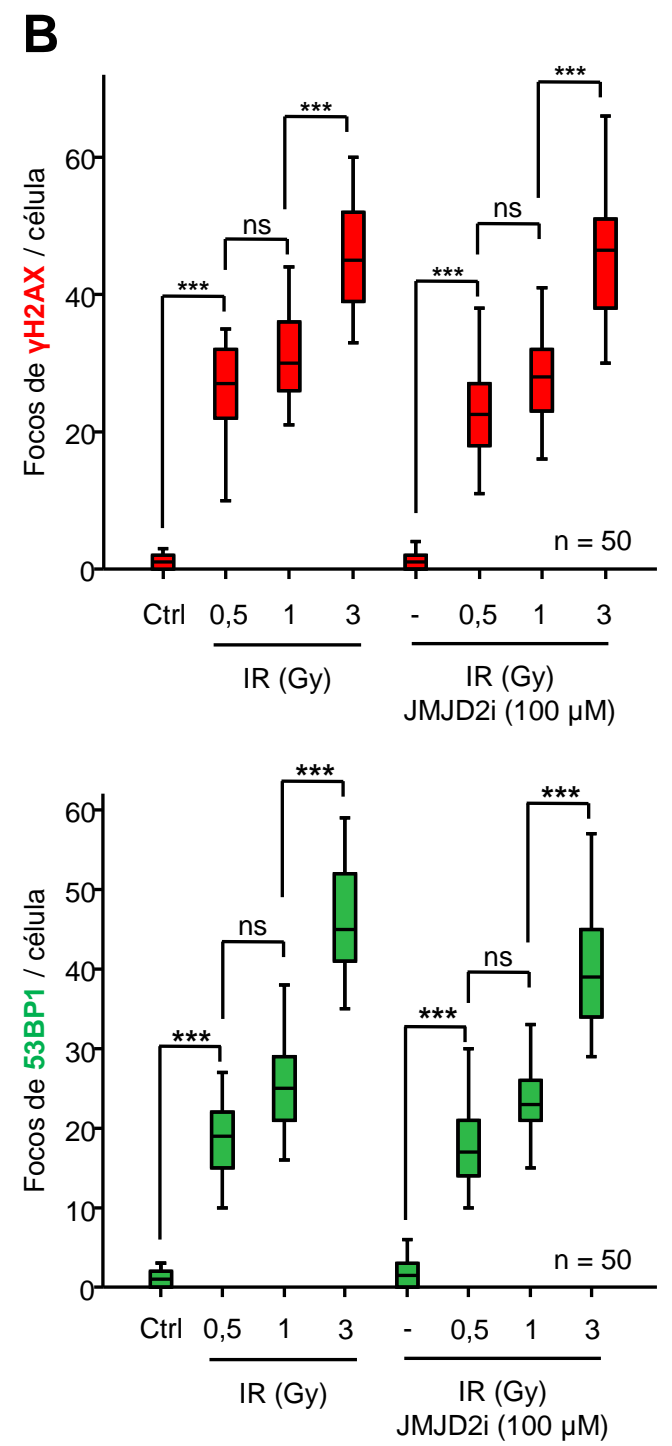

Figura 33: La inhibición de demetilasas mediada por JMJD2i no afecta a la formación de focos de $\mathrm{YH} 2 \mathrm{AX}$ y 53BP1 en respuesta a IR. Se retiró el suero del medio de cultivo de las células U2OS (48 horas, 0,5\% FBS) y se incubaron con el inhibidor JMJD2i (100 $\mu \mathrm{M}$ ) durante 24 horas. Posteriormente, se irradiaron (0,5-1-3 Gy) y se analizó la formación de focos de $\mathrm{YH} 2 \mathrm{AX}$ y 53BP1 mediante microscopía confocal. A. Formación de focos de $\mathrm{yH2AX}$ y 53BP1 tras el tratamiento con JMJD2i y/o IR. B. Cuantificación de los focos de yH2AX y 53BP1 en respuesta al tratamiento con JMJD2i, IR o su combinación. La significación estadística se calculó con el test de comparación múltiple de Dunn's. ns: no significativo; ${ }^{* * *}, p<0,001$. 


\subsection{El inhibidor chaetocin impide la formación de focos de 53BP1 asociada al tratamiento con olaparib}

Ante el efecto mostrado por el inhibidor chaetocin sobre la formación de focos de 53BP1 inducidos por el tratamiento con radiación ionizante, quisimos descartar que dicho efecto se debiese a la fuente de daño empleada. Por este motivo, decidimos preincubar las células U2OS con chaetocin para, posteriormente, tratarlas durante 24 horas con concentraciones crecientes de olaparib. Al igual que ocurría con la IR, el daño en el ADN causado por olaparib, detectado mediante la formación de focos de YH2AX y 53BP1, no se veía afectado en ausencia de chaetocin, pero la presencia de este inhibidor impidió de nuevo que la proteína 53BP1 se reclutase adecuadamente a las zonas dañadas del ADN (Figura 34).

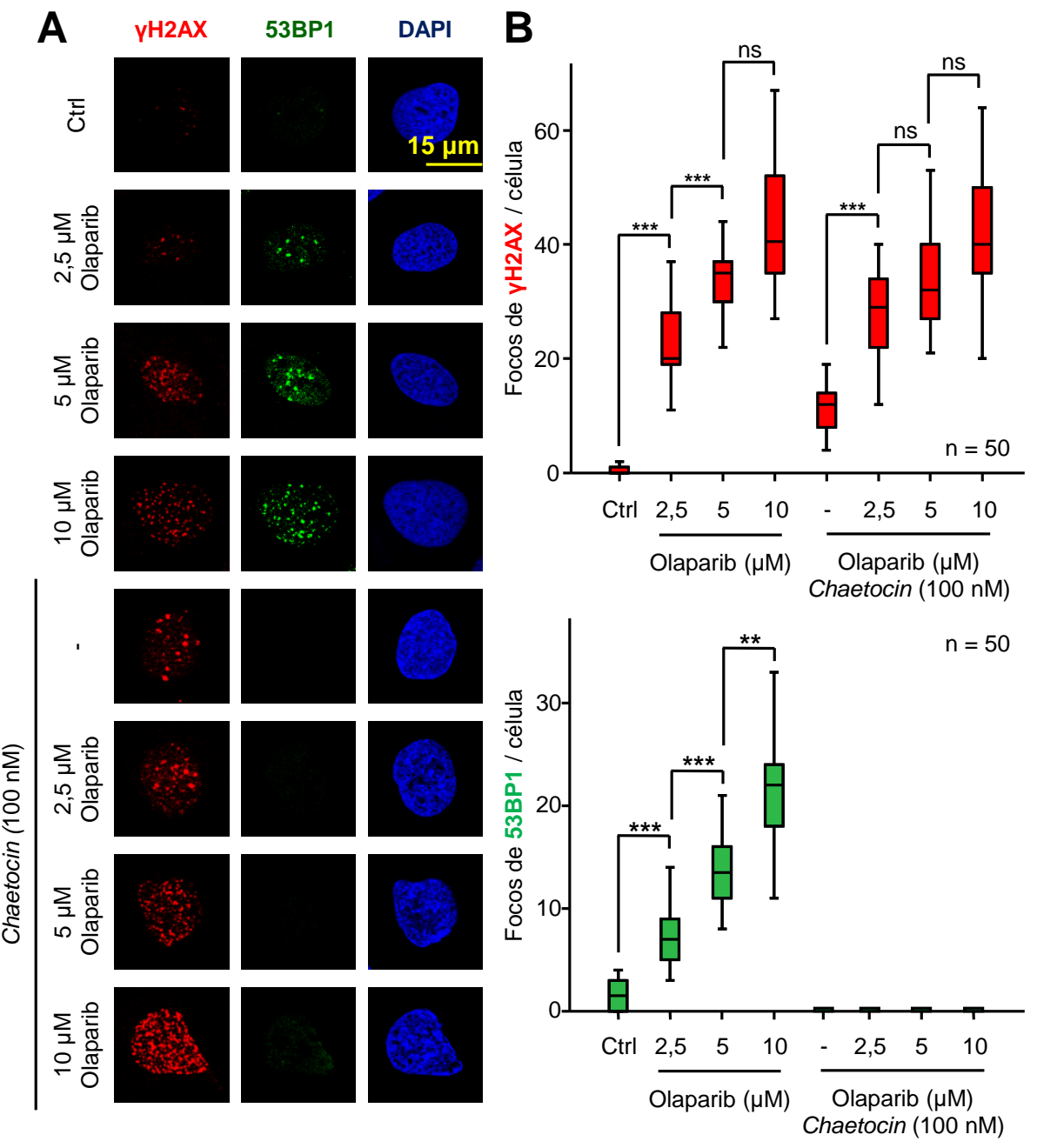


Figura 34: El inhibidor chaetocin impide la correcta formación de focos de 53BP1 tras el tratamiento con olaparib. Tras retirar el suero del medio de cultivo (48 horas, $0,5 \% \mathrm{FBS}$ ), se preincubaron las células U2OS con el inhibidor chaetocin durante 3 horas y, posteriormente, se añadió el olaparib (2,3-5-10 $\mu \mathrm{M})$ y se incubaron los dos compuestos juntos durante 24 horas. Después de estos tratamientos, se evaluó la formación de focos de YH2AX y 53BP1 por microscopía confocal. A. Focos de $\mathrm{yH} 2 \mathrm{AX}$ y 53BP1 en respuesta al tratamiento con olaparib en presencia o ausencia del inhibidor chaetocin. B. Cuantificación del número de focos de reparación tras el tratamiento con olaparib y/o chaetocin. La significación estadística se calculó con el test de comparación múltiple de Dunn's. ns: no significativo; ${ }^{* *}, p<0,01 ;{ }^{* \star *}, p<0,001$.

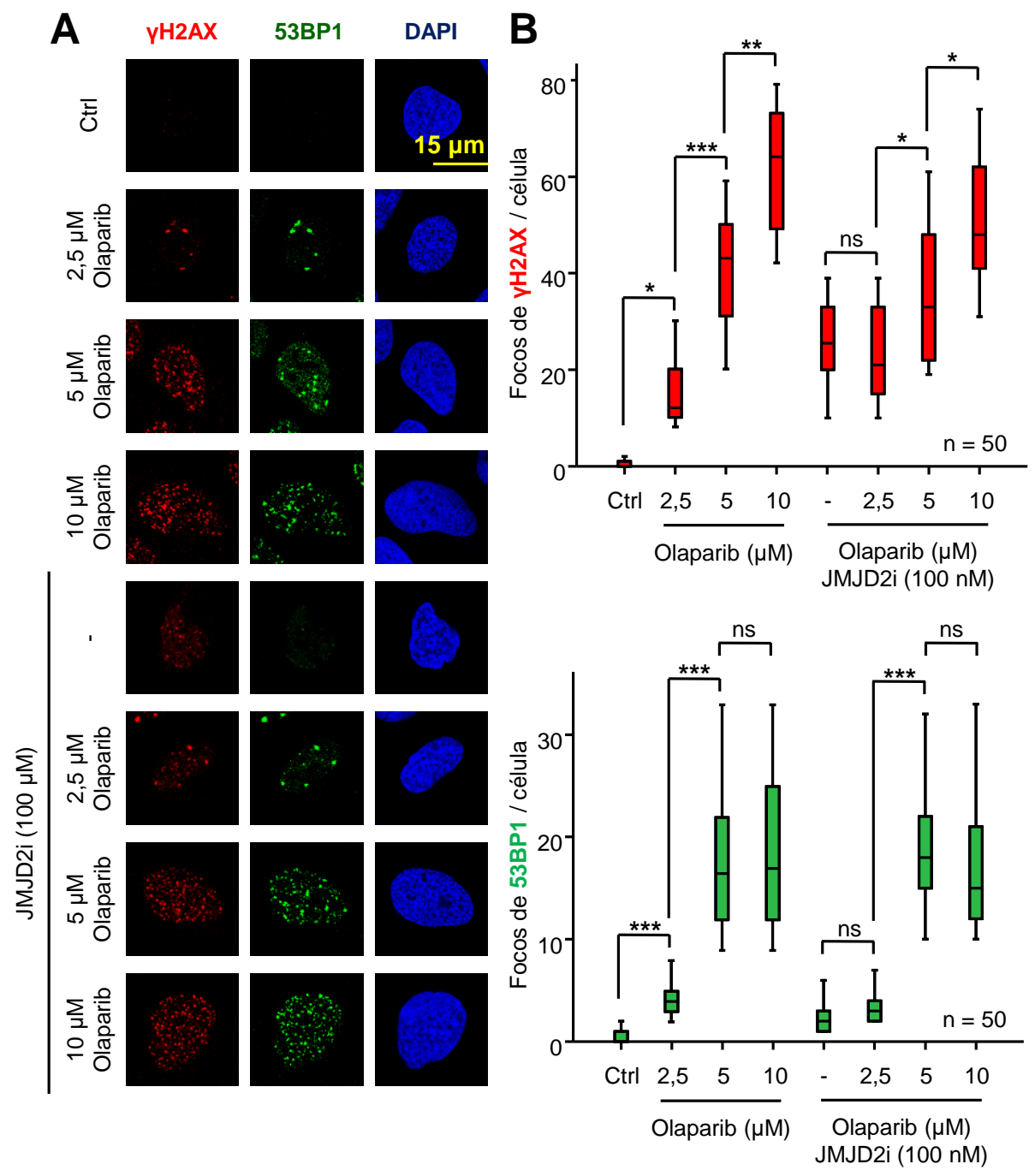


Figura 35: El tratamiento con el inhibidor de demetilasas JMJD2i no altera la formación de focos de 53BP1 en respuesta a olaparib. Se retiró el suero del medio de cultivo de las células U2OS (48 horas, 0,5\% FBS) y se preincubaron con el inhibidor JMJD2i (100 $\mu \mathrm{M}$; 3 horas). A continuación, se trataron con olaparib $(2,5-5-10 \mu \mathrm{M})$ y se incubaron los dos compuestos juntos durante 24 horas. Posteriormente, se analizó la formación de focos de $\mathrm{YH} 2 \mathrm{AX}$ y $53 \mathrm{BP} 1$ por microscopía confocal. A. Focos de $\mathrm{YH} 2 \mathrm{AX}$ y 53BP1 asociados al tratamiento con olaparib y/o JMJD2i. B. Cuantificación de los focos de $\mathrm{YH} 2 \mathrm{AX}$ y 53BP1 formados tras el tratamiento con olaparib en presencia o ausencia del inhibidor de demetilasas JMJD2i. La significación estadística se calculó con el test de comparación múltiple de Dunn's. ns: no significativo; *, $\mathrm{p}<0,05 ;{ }^{* *}, \mathrm{p}<0,01 ;{ }^{* * *}, \mathrm{p}<0,001$.

Como en el apartado anterior, nos preguntamos si la inhibición de las demetilasas mediada por JMJD2i se comportaba de manera opuesta al inhibidor chaetocin en la formación de focos de 53BP1. Para evaluar esta hipótesis, tratamos las células U2OS durante 3 horas con el inhibidor JMJD2i y, a continuación, les añadimos el olaparib y las incubamos con ambos compuestos (24 horas). En este caso, el inhibidor de demetilasas no alteraba ni la formación de focos de $\mathrm{yH} 2 \mathrm{AX}$ ni la de 53BP1 en respuesta a olaparib (Figura 35).

\subsection{El efecto del inhibidor chaetocin sobre la formación de focos de 53BP1 no depende del tiempo transcurrido desde la irradiación}

Los experimentos previos realizados con el inhibidor chaetocin en respuesta a IR se llevaron a cabo 30 minutos después de inducir el daño en el ADN, cuando el número de focos de los dos marcadores de reparación utilizados, yH2AX y 53BP1, alcanza su punto más alto. Sin embargo, pensamos que el inhibidor chaetocin podría estar causando únicamente un retraso en la aparición de los focos de reparación de 53BP1. Para investigarlo, analizamos la formación de focos de ambas proteínas a distintitos tiempos tras la irradiación, tanto en presencia como en ausencia de chaetocin. Los resultados obtenidos demostraron que la proteína 53BP1 era incapaz de acumularse en las regiones del ADN dañadas independientemente del tiempo que hubiera pasado desde la exposición a la IR en presencia del inhibidor de metiltransferasas. Por el contrario, el número de focos de $\mathrm{y} H 2 \mathrm{AX}$, que aumentó de manera drástica durante los primeros instantes post-IR (15-30 minutos), disminuyó progresivamente hasta alcanzar un nivel residual que era más alto tras el tratamiento con chaetocin que en condiciones control (Figura 36). 


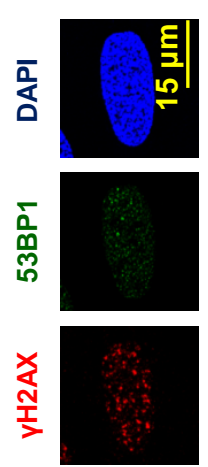

u!̣u Gı
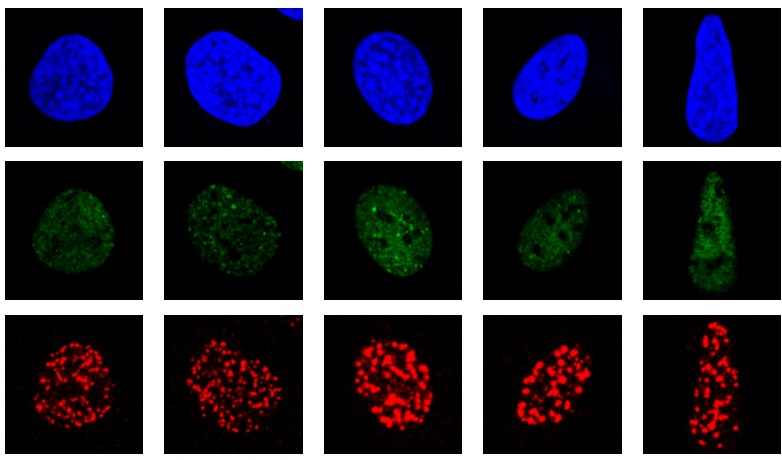

u!̣ $0 \mathcal{E}$

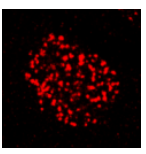

u!̣u 09

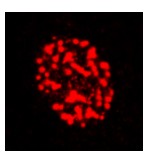

u!̣u 08 เ

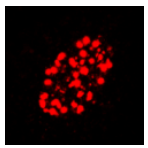

u!̣ய $09 \varepsilon$

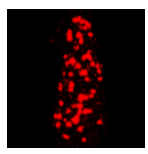

u!̣ $02 L$

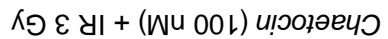
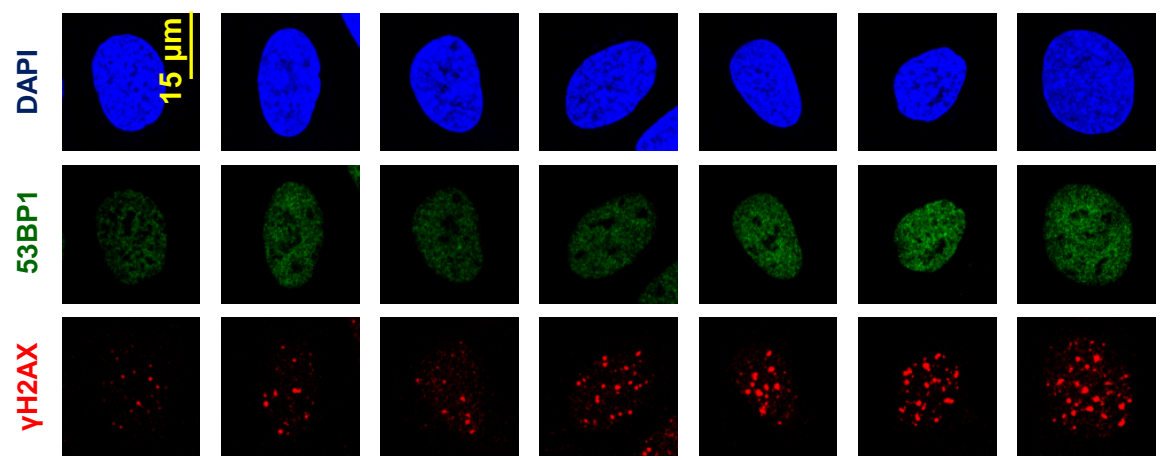

ןu!̣u 0
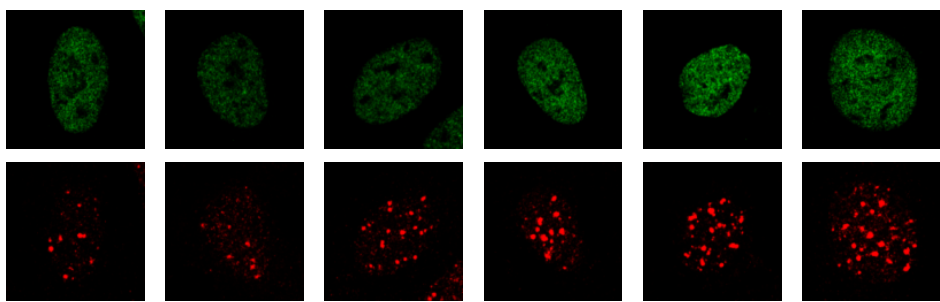

u!̣ G

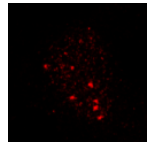

u!̣u $0 \mathcal{E}$
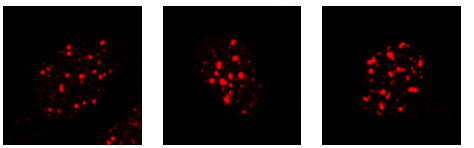

u!̣u $09 \varepsilon$

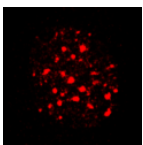

u!̣u 09

u!̣ 08 เ

u!̣ $02 L$

(wu 001) น!วоาәечว
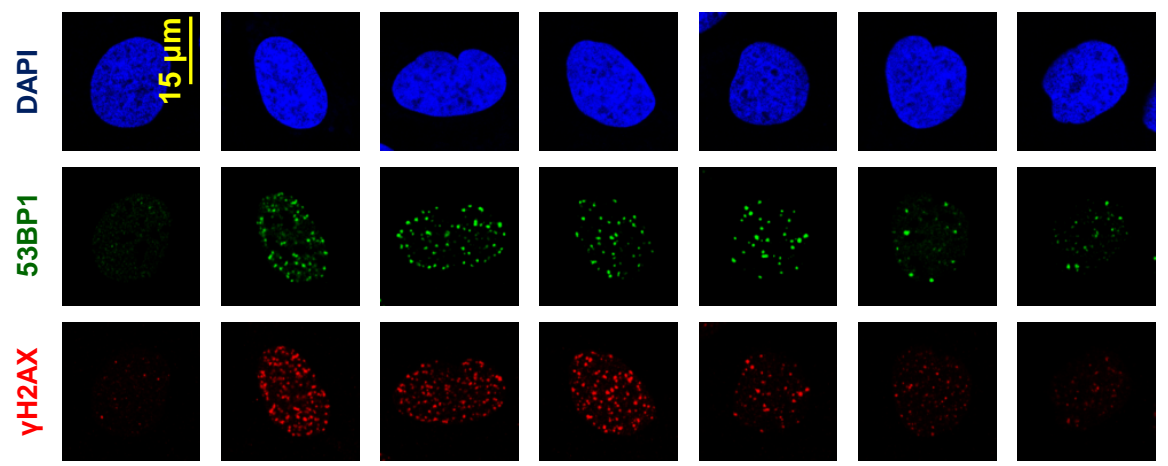

ןำ

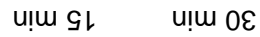

u!̣u 09

u!̣u 08 เ

u!̣u $09 \varepsilon$

u!̣m 0ZL

$<$

রり $\varepsilon$ प् 


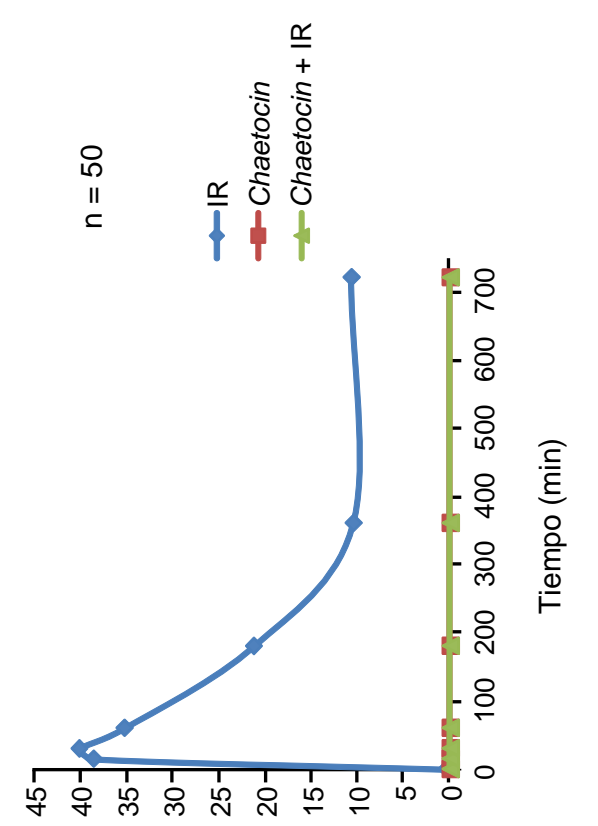

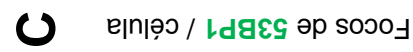

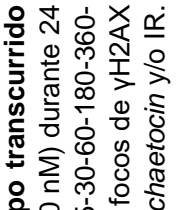

은 ल원

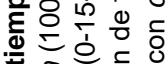

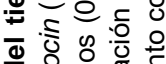

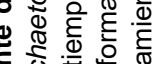

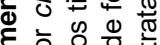

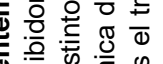

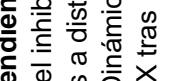

ฮ

웡 융 원

등 융

点

ก.

๑

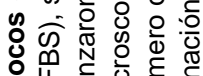

눈

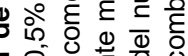

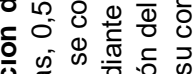

के

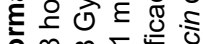

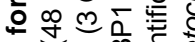

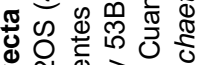

웡

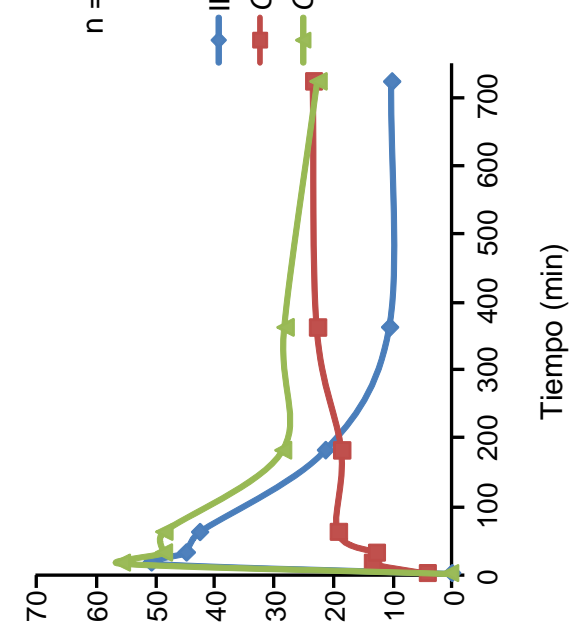

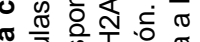

긍

응 0 응

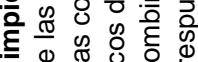

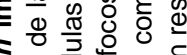

워웡

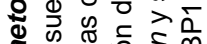

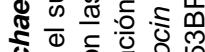

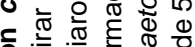

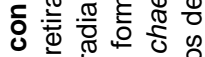

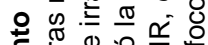

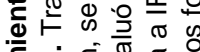

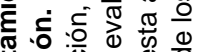

制

웧

พ

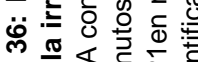

๘

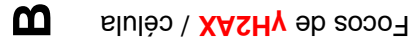




\subsection{La inhibición de la metilación asociada al tratamiento con chaetocin no modifica el reclutamiento de otras proteínas implicadas en la reparación de las DSBs generadas por IR}

Con el fin de determinar si el efecto del inhibidor chaetocin afectaba también a otros componentes de la ruta de reparación de las DSBs, analizamos la formación de focos y los niveles proteicos de otras dos proteínas implicadas en la respuesta al daño, NBS1 y MDC1. Elegimos a NBS1 por ser miembro del complejo MRN, que protege los extremos generados tras la rotura y actúa como punto de ensamblaje para otras proteínas implicadas en la reparación $(81,82)$. Por otro lado, analizamos la proteína MDC1 porque se une a la histona $\mathrm{H} 2 \mathrm{AX}$ fosforilada $(\mathrm{YH} 2 \mathrm{AX})$ en respuesta al daño en el ADN (88), que no se afecta por el tratamiento con chaetocin, y porque interacciona con 53BP1 y favorece su acumulación en las regiones donde se han producido las DSBs $(94,95)$.

Tras evaluar la formación de focos de NBS1 en respuesta al daño generado por IR y en presencia o ausencia de chaetocin, vimos que los niveles de este componente del complejo MRN aumentaban como consecuencia del daño inducido por IR y/o el inhibidor de metiltransferasas, siendo especialmente significativo el incremento asociado al tratamiento con chaetocin e IR (Figura 37.A).

Al igual que ocurría con NBS1, la formación de focos de MDC1 tampoco se vio alterada por la inhibición de la metilación, alcanzándose el mayor número de focos tras la exposición a la radiación, independientemente de la presencia o ausencia de chaetocin (Figura 37.B). Además, los niveles proteicos de ambas proteínas no sufrieron variaciones significativas asociadas a la radiación o al tratamiento con el inhibidor de metiltransferasas (Figura 37.C). 

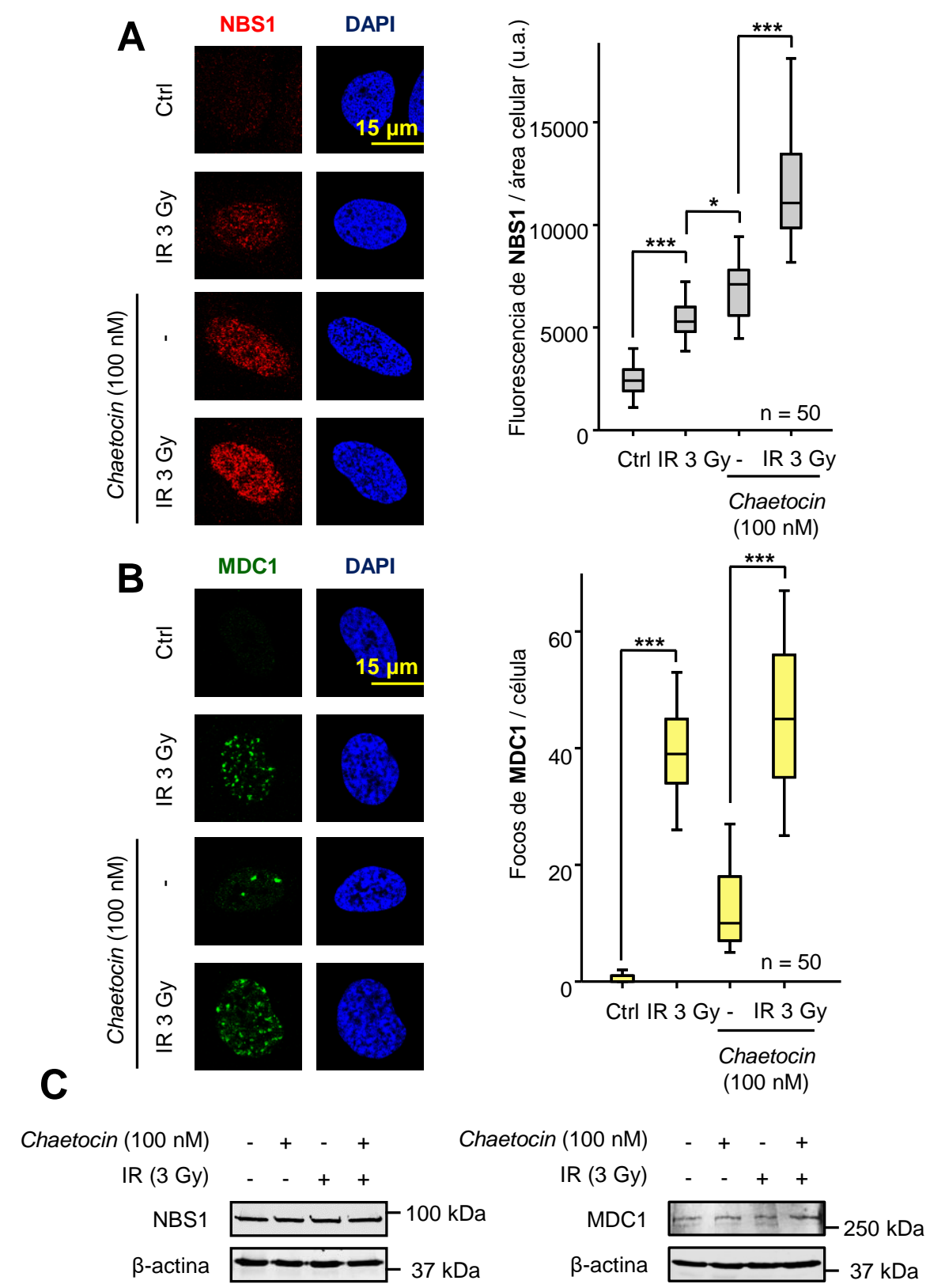
Figura 37: La inhibición de la metilación mediada por chaetocin no afecta ni a la formación de focos de NBS1 y MDC1 ni a sus niveles proteicos. Se retiró el suero del medio de cultivo de las células U2OS (48 horas, 0,5\% FBS) y se incubaron con chaetocin durante 24 horas. Posteriormente, se irradiaron (3 Gy) y, pasados 30 minutos, se analizó la formación de focos de NBS1 y MDC1 mediante microscopía confocal y los niveles proteicos de ambas proteínas por western blot. A. Focos de NBS1 en respuesta a IR y/o chaetocin, y cuantificación de los niveles de esta proteína, medidos a través de su fluorescencia. B. Formación de focos de MDC1 tras el tratamiento con chaetocin, IR o su combinación. La significación estadística de las figuras A y B se calculó con el test de comparación múltiple de Dunn's. C. Western blots que indican los niveles proteicos de NBS1 y MDC1. * $p<0,05 ;{ }^{* * *}, p<0,001$.

\subsection{La pérdida de la acetilación de la histona $\mathrm{H} 4$ en la lisina 16 no interfiere en la formación de focos de 53BP1 en respuesta a IR}

Como se ha mencionado en la introducción, la acetilación de la H4K16 es uno de los principales marcadores de relajación local de la cromatina asociada a la respuesta al daño en el ADN (69-71). Por esta razón, quisimos estudiar si la pérdida de esta acetilación asociada a la inhibición de Tip60 alteraba la formación de focos de 53BP1. Tras inducir daño en el ADN con IR, observamos un aumento dosis-dependiente de los niveles de la H4K16ac y del número de focos de 53BP1. Sin embargo, la pérdida de la acetilación de la H4K16 debida al tratamiento con MG149, un inhibidor específico de Tip60, no interfirió en la formación de estos focos de reparación en respuesta a IR (Figura 38).

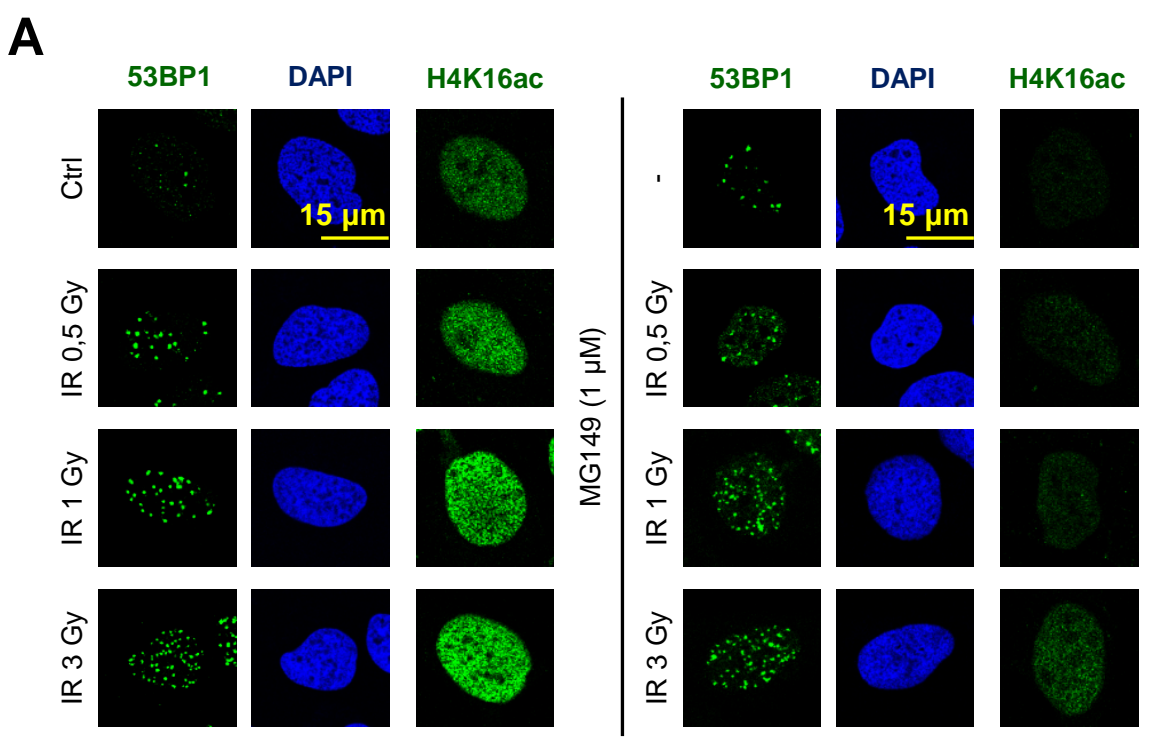



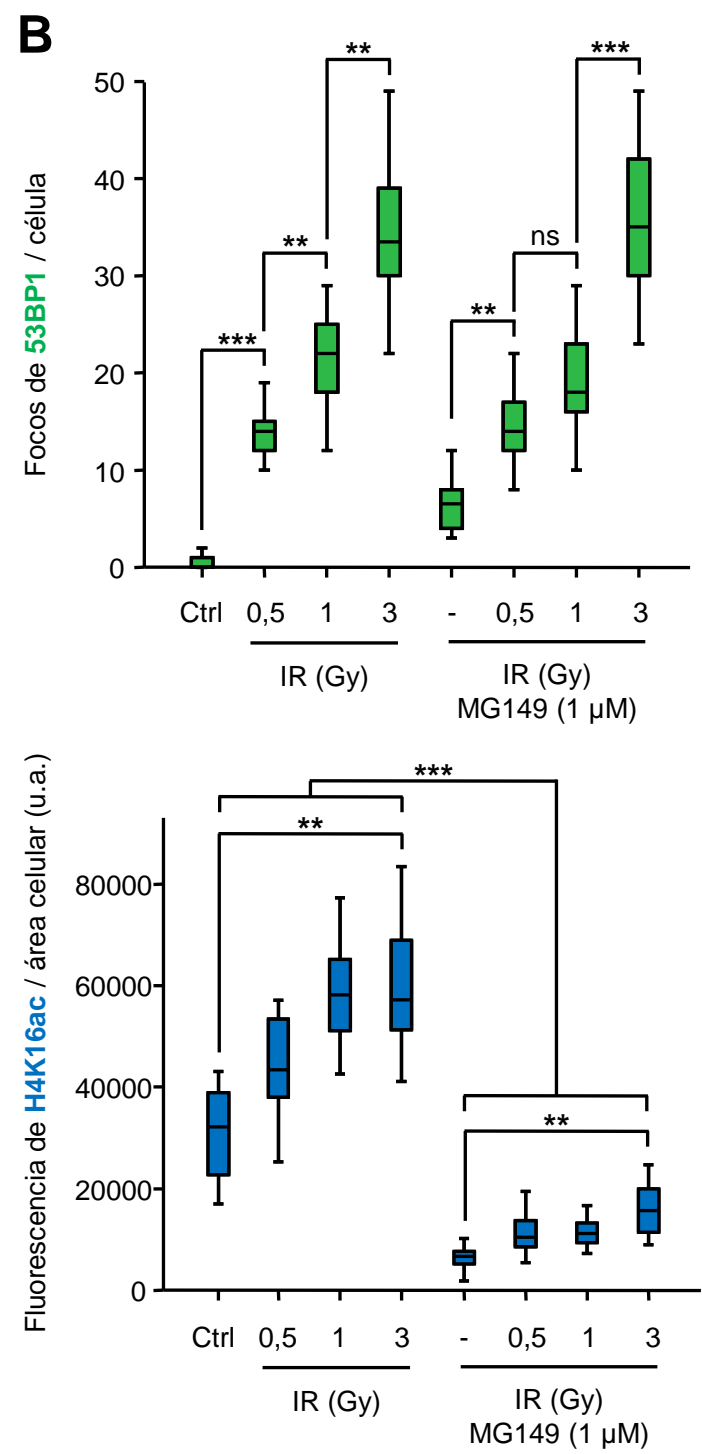

Figura 38: La inhibición de Tip60 mediada por MG149 reduce significativamente los niveles de H4K16ac, pero no interfiere en la formación de focos de 53BP1. Tras retirar el suero del medio de cultivo de las células U2OS (48 horas, 0,5\% FBS), se incubaron con MG149 $(1 \mu \mathrm{M})$ y, 24 horas después, se irradiaron ( $3 \mathrm{~Gy}$ ). Pasados 30 minutos, se evaluaron, por separado, la formación de focos de 53BP1 y los niveles de acetilación de la H4K16 mediante microscopía confocal. A. Focos de 53BP1 y niveles de la H4K16ac tras la inducción de daño en el ADN en presencia o ausencia de MG149. B. Cuantificación del número de focos de 53BP1 y de la acetilación de la H4K16 en respuesta a IR y/o al tratamiento con el inhibidor MG149. La significación estadística se calculó con el test de comparación múltiple de Dunn's. ns: no significativo; ${ }^{* *}, p<0,01 ;{ }^{* * *}, p<0,001$. 


\subsection{El inhibidor chaetocin reduce los niveles de la dimetilación de la histona $\mathrm{H} 4$ en la lisina 20 e, indirectamente, favorece la acetilación de la H4K16}

Hasta este momento hemos demostrado que el inhibidor chaetocin impide la correcta formación de focos de 53BP1 en respuesta al daño génico inducido sin afectar al reclutamiento de otras proteínas clave en la respuesta como H2AX, NBS1 o MDC1. Ahora bien, para caracterizar de manera más precisa el efecto de este inhibidor de metiltransferasas, nos centramos en una de las modificaciones covalentes en las histonas asociadas específicamente al reclutamiento de 53BP1, la dimetilación de la histona $\mathrm{H} 4$ en la lisina 20 (H4K20me2), mediada por SET8 y MMSET en respuesta al daño. La proteína 53BP1 se une a esta modificación a través de sus dominios Tudor, lo que le permite acumularse en las regiones dañadas y servir de anclaje para otros factores implicados en la reparación de las DSBs por unión de extremos no homólogos $(97,98)$.

Tras analizar los resultados obtenidos, vimos que el tratamiento con el inhibidor chaetocin reducía significativamente los niveles de la H4K20me2 en respuesta al daño génico inducido por IR (Figura 39.A y B). Además, pudimos comprobar también mediante western blot el efecto del inhibidor sobre esta modificación en ausencia de daño, el cual no pudimos detectar por inmunofluorescencia (Figura 39.C).

Paralelamente a este experimento, evaluamos también los niveles de la H4K16ac en presencia o ausencia de chaetocin tras la inducción de daño en el ADN con IR, ya que es necesario que este residuo se deacetile para que 53BP1 pueda unirse adecuadamente a la H4K20me2 (104). En este caso, observamos que el aumento de esta acetilación asociado a la irradiación no variaba significativamente en presencia del inhibidor chaetocin (Figura 40), lo cual concuerda con la reducción de los niveles de la H4K20me2 observados anteriormente en respuesta a IR (Figura 39). 
A
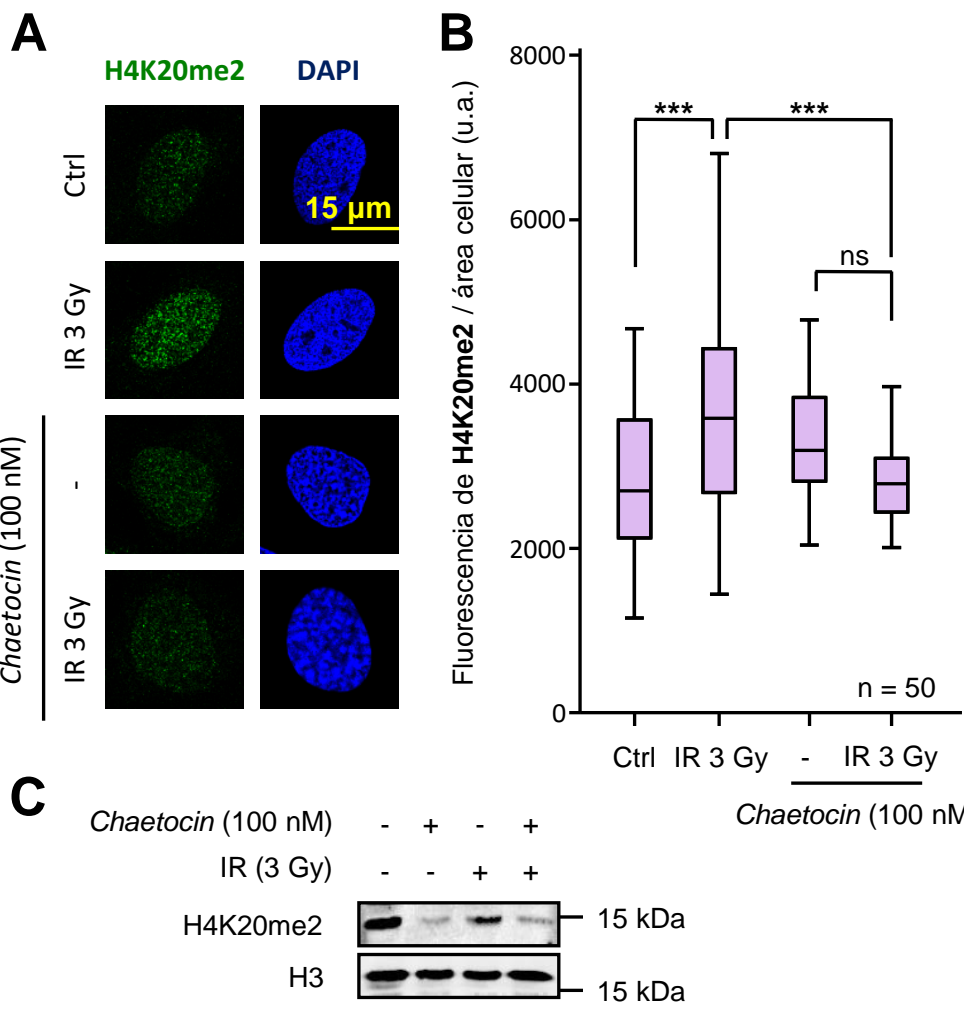

Figura 39: El inhibidor chaetocin reduce considerablemente los niveles de la H4K20me2 en respuesta al daño génico inducido por IR. Se retiró el suero del medio de cultivo de las células U2OS (48 horas, 0,5\% FBS) y se incubaron con chaetocin durante 24 horas. Posteriormente, se irradiaron ( 3 Gy) y, pasados 30 minutos, se analizaron los cambios en la H4K20me2 mediante microscopía confocal y western blot. A. Dimetilación de la H4K20 en respuesta al tratamiento con chaetocin y/o IR. B. Cuantificación de los niveles de la H4K20me2 tras la inducción de daño génico con IR y el tratamiento con chaetocin. La significación estadística se calculó con el test de comparación múltiple de Dunn's. C. Western blot que muestra los cambios en la H4K20me2 asociados al tratamiento con chaetocin y/o IR, partiendo de extractos enriquecidos en histonas. ns: no significativo; ${ }^{* *}, \mathrm{p}<0,001$. 
A
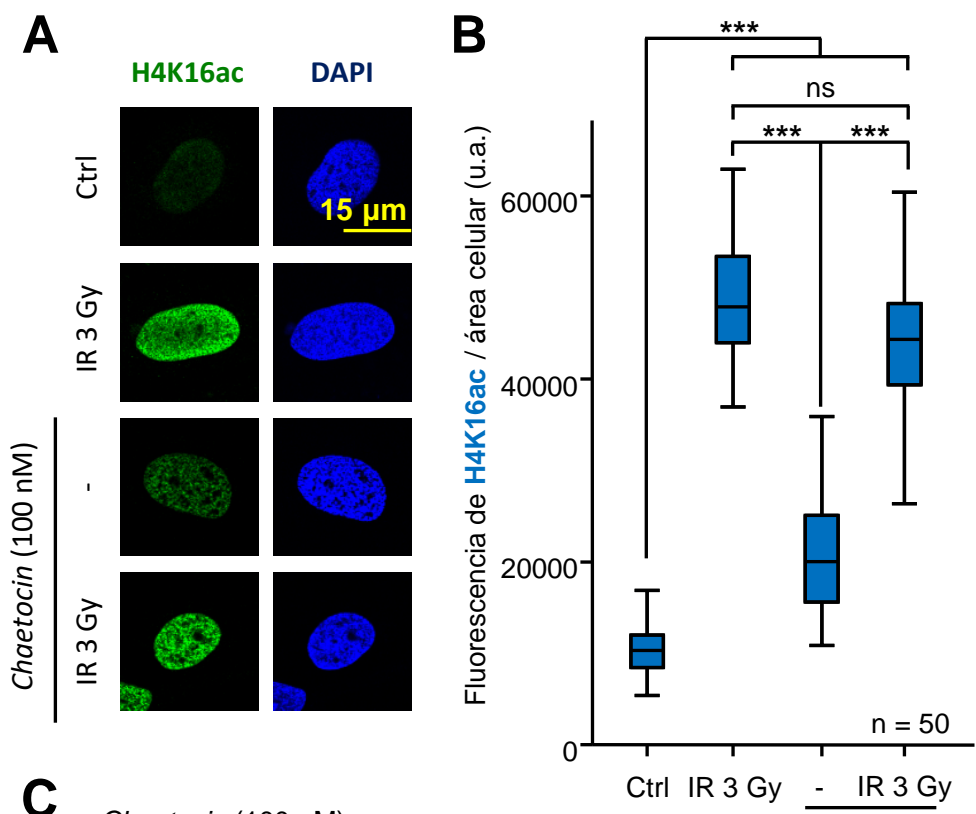

C

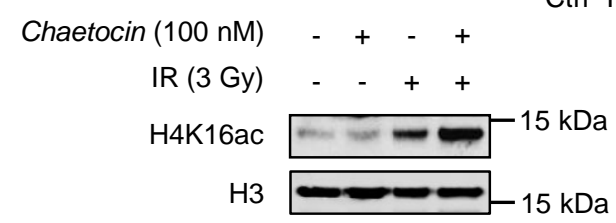

Chaetocin (100 nM)

Figura 40: La acetilación de la H4K16 aumenta en respuesta al daño inducido con IR, pero no varía en presencia o ausencia de chaetocin. Tras retirar el suero del medio de cultivo de las células U2OS (48 horas, 0,5\% FBS), se incubaron con el inhibidor chaetocin durante 24 horas y se irradiaron (3 Gy) para evaluar posteriormente los cambios en la H4K16ac mediante microscopía confocal y western blot. A. Acetilación de la H4K16 en respuesta al tratamiento con chaetocin y/o IR. B. Cuantificación de los niveles de la H4K16ac tras la inducción de daño génico con IR y el tratamiento con chaetocin. La significación estadística se calculó con el test de comparación múltiple de Dunn's. C. Western blot que muestra los cambios en la H4K16ac asociados al tratamiento con chaetocin y/o IR, partiendo de extractos enriquecidos en histonas. ns: no significativo; ${ }^{* * *}, \mathrm{p}<0,001$. 


\section{IMPLICACIÓN DE LA QUINASA HUMANA VRK1 EN LA REGULACIÓN DE LAS MODIFICACIONES COVALENTES DE LAS HISTONAS H3 Y H4}

Las modificaciones covalentes en las colas de las histonas juegan un papel esencial en distintos procesos celulares como la replicación, la transcripción o la reparación del $A D N$, donde el balance entre cromatina compactada y relajada debe regularse de manera precisa $(22,231)$.

VRK1 tiene como sustratos a las histonas H3 y H2A $(85,152,179)$ y el patrón de acetilación en las histonas $\mathrm{H} 3$ y $\mathrm{H} 4$ se ve alterado al silenciar esta quinasa (85). Además, en este trabajo de tesis doctoral hemos demostrado cómo el silenciamiento de VRK1 altera la acetilación de la H4K16 en respuesta al tratamiento con olaparib y/o $I R$, clave en la relajación local de la cromatina asociada a la reparación del ADN. En base a todos estos indicios, decidimos estudiar las variaciones en la acetilación y metilación de residuos concretos en las histonas H3 y H4 implicados en la relajación y/o compactación de la cromatina.

\subsection{Efecto del silenciamiento de VRK1 sobre la acetilación de la lisina $\mathbf{1 6}$ de la histona $\mathrm{H} 4$}

El primer residuo que quisimos caracterizar fue la acetilación de la H4K16 (H4K16ac), dado que ya existen datos en la bibliografía que hablan de las consecuencias que tiene la ausencia de VRK1 sobre esta modificación covalente (85). Con este objetivo, silenciamos la expresión del gen VRK1 durante 96 horas en la línea celular A549 con dos ARNi (siVRK1-02 y -03) y retiramos el suero del medio de cultivo durante 48 horas para minimizar los cambios en esta acetilación que pudieran estar asociados al ciclo celular. A continuación, analizamos las variaciones en la H4K16ac mediante microscopía confocal y western blot. Los resultados obtenidos con ambas técnicas demostraron que la ausencia de VRK1 conlleva una disminución significativa de los niveles de la H4K16ac (Figura 41). 
A

H4K16ac

VRK1

DAPI

\section{DETALLE}

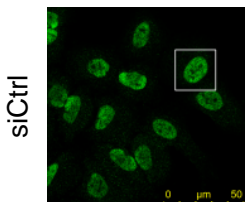
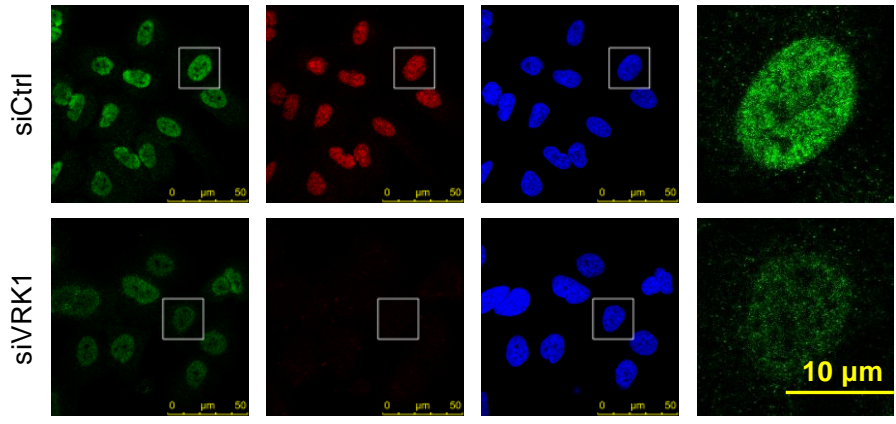

B

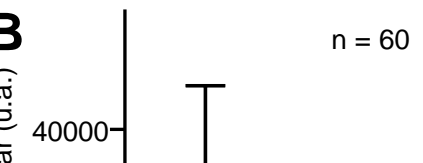

C

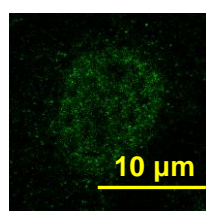

$10 \mu \mathrm{m}$

\section{VRK1}

$\beta$-actina

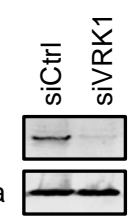

D

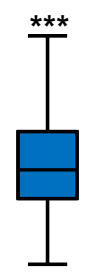

0

siCtrl

siVRK1

H3

H4K16ac/H3 10,22

\section{E}

\section{H4K16}

\section{H4K16ac}

Figura 41: El silenciamiento de VRK1 reduce significativamente los niveles de la H4K16ac. Se transfectaron las células A549 con 3 ARNi (siCtrl y una combinación de siVRK1-02 y -03) durante 96 horas y se retiró el suero del medio de cultivo (48 horas, 0,5\% FBS). A continuación, se analizaron los niveles de la H4K16ac por microscopía confocal y western blot. A. Cambios en acetilación de la H4K16 tras el silenciamiento de VRK1. B. Cuantificación de los niveles de la H4K16ac en presencia o ausencia de VRK1. La significación estadística se calculó con el test de la U de Mann-Whitney. C. Comprobación del silenciamiento de VRK1 mediante western blot. D. Extractos enriquecidos en histonas en los que se aprecian los cambios en la acetilación de la H4K16 en ausencia de VRK1. La cuantificación de las bandas representa el cociente H4K16ac/H3 relativizado con respecto al control. E. Representación esquemática del efecto del silenciamiento de VRK1 sobre la H4K16ac. siCtrl: siC; siVRK1: siVRK1-02 + siVRK1-03. ${ }^{* * *}$, $\mathrm{p}<0,001$. 


\subsubsection{La inhibición de las deacetilasas de histonas compensa el efecto del silenciamiento de VRK1 sobre la H4K16ac}

La dinámica de acetilación/deacetilación de la H4K16 depende de la acción de dos principales grupos de enzimas, las acetiltransferasas y las deacetilasas de histonas (HATs y HDACs, respectivamente). Para esclarecer los mecanismos moleculares a través de los cuales VRK1 regula los cambios en la H4K16ac, evaluamos, en primer lugar, el efecto de dos inhibidores de HDACs ya descritos en la bibliografía, entinostat y SAHA (232-234), sobre esta acetilación en presencia o ausencia de VRK1. Tras el tratamiento con ambos inhibidores, los niveles de la H4K16ac aumentaron significativamente, independientemente de que se hubiese silenciado o no la expresión de VRK1 (Figura 42).

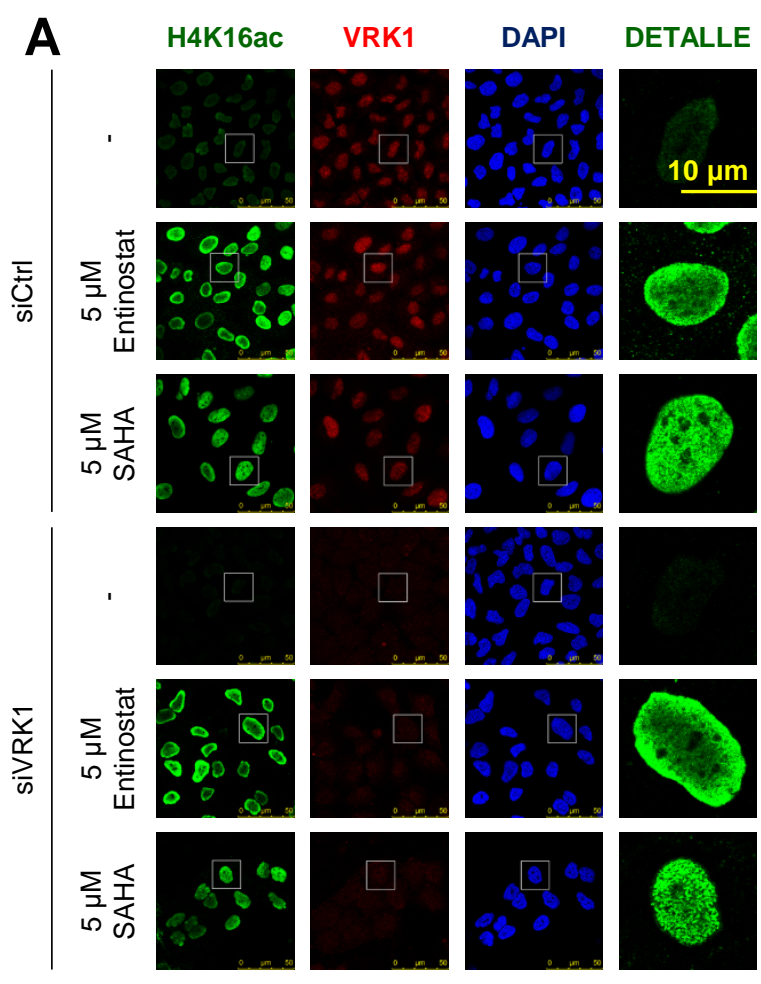




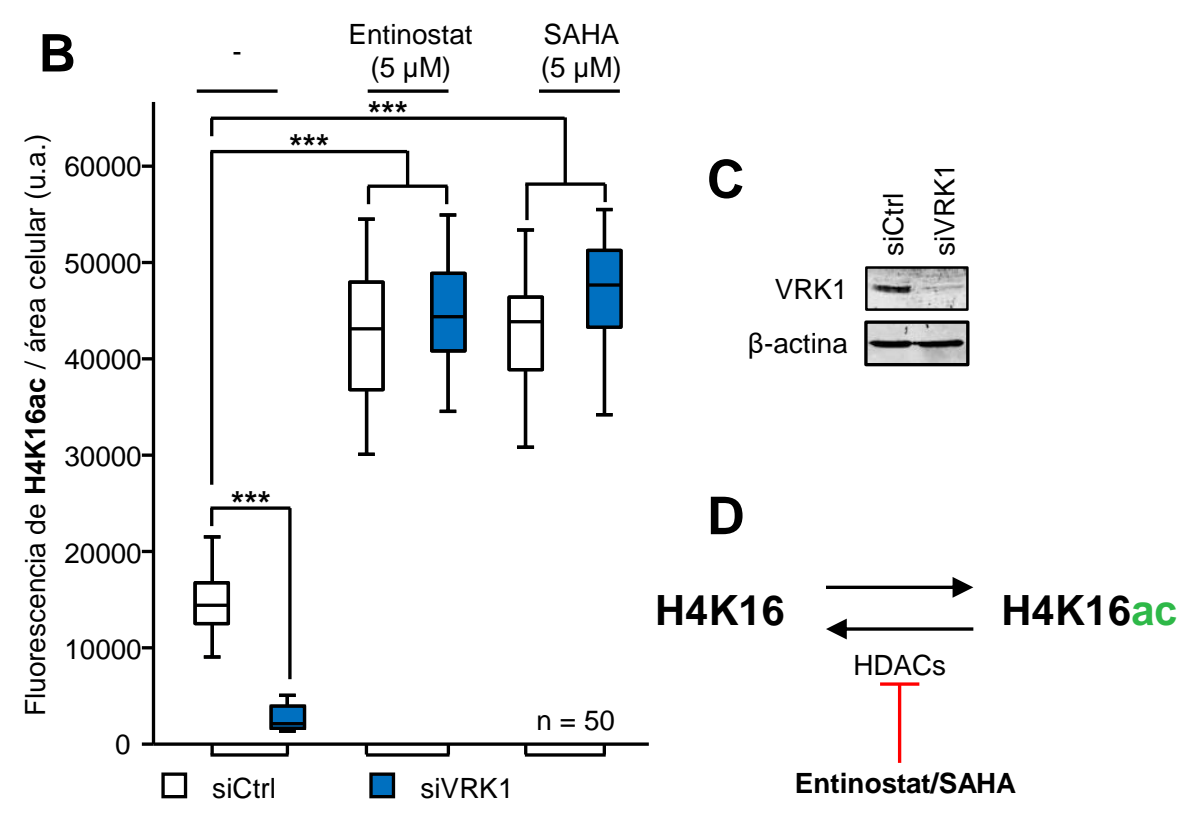

Figura 42: Los inhibidores entinostat y SAHA promueven un aumento significativo de los niveles de la H4K16ac que no depende de la presencia o ausencia de VRK1. Tras silenciar la expresión génica de VRK1 (96 horas) y retirar el suero del medio de cultivo de las células A549 (48 horas, 0,5\% FBS), se incubaron con los inhibidores entinostat (5 $\mu \mathrm{M})$ y SAHA (5 $\mu \mathrm{M})$ durante 24 horas y se evaluaron los niveles de la H4K16ac mediante microscopía confocal. A. Acetilación de la H4K16 en respuesta al tratamiento con entinostat y SAHA en presencia o ausencia de VRK1. B. Cuantificación de los niveles de la H4K16 asociados al tratamiento con entinostat y SAHA tras silenciar o no la expresión de VRK1. La significación estadística se calculó con el test de Kluskal-Wallis y el post hoc T2 de Tamhane. C. Análisis de los niveles proteicos de VRK1 tras el silenciamiento génico. D. Esquema en el que se indica el grupo de enzimas diana de los inhibidores entinostat y SAHA. siCtrl: siC; siVRK1: siVRK1-02 + siVRK1-03. ***, $\mathrm{p}<0,001$.

\subsubsection{La disminución de los niveles de la H4K16ac en ausencia de VRK1 es comparable al efecto que tiene el inhibidor MG149 sobre esta acetilación}

Paralelamente al experimento con los inhibidores de deacetilasas, estudiamos el efecto de dos inhibidores de acetiltransferasas de histonas con distinta especificidad, C646, frente a p300/CBP, y MG149, frente a Tip60, los cuales se habían descrito previamente $(235,236)$. Dado que sólo Tip60, y no p300/CBP, media la acetilación de la H4K16, esperábamos un efecto diferencial entre los dos compuestos. El análisis de la acetilación de la H4K16 tras el tratamiento con los inhibidores de HATs reveló que el inhibidor MG149 reducía los niveles de la H4K16ac de manera similar al silenciamiento de VRK1, mientras que el otro compuesto, C646, no mostraba diferencias significativas con respecto al control. Ahora bien, la fluorescencia asociada 
a esta modificación covalente de la histona H4 sí que disminuyó en ausencia de VRK1 con independencia del inhibidor de HATs utilizado (Figura 43).

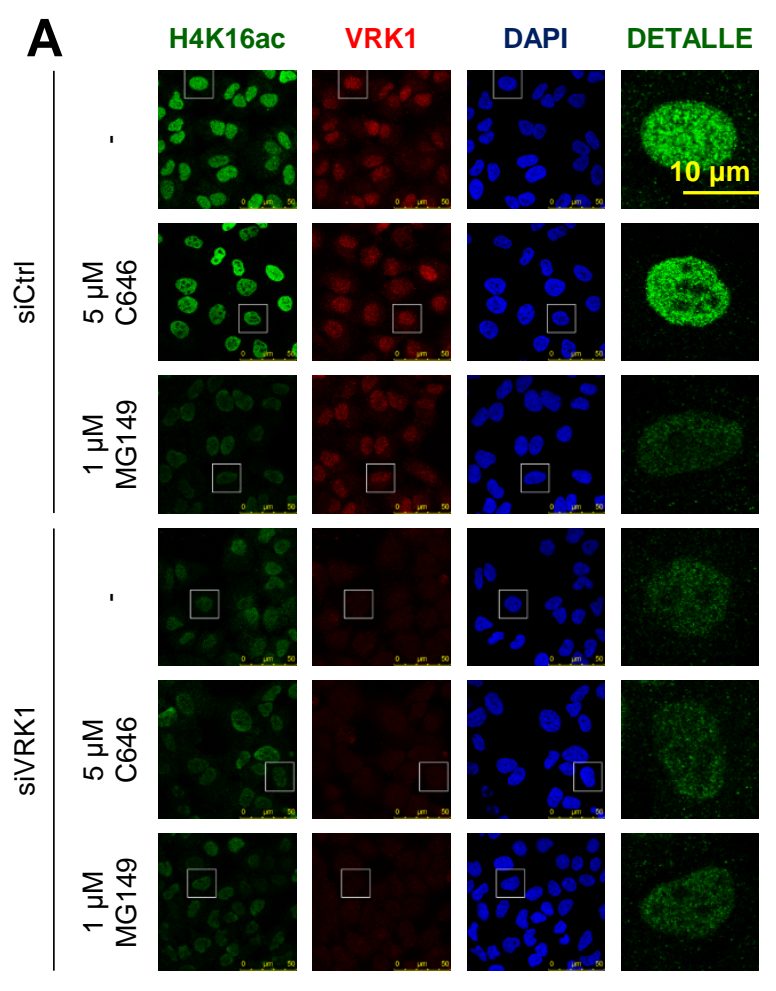




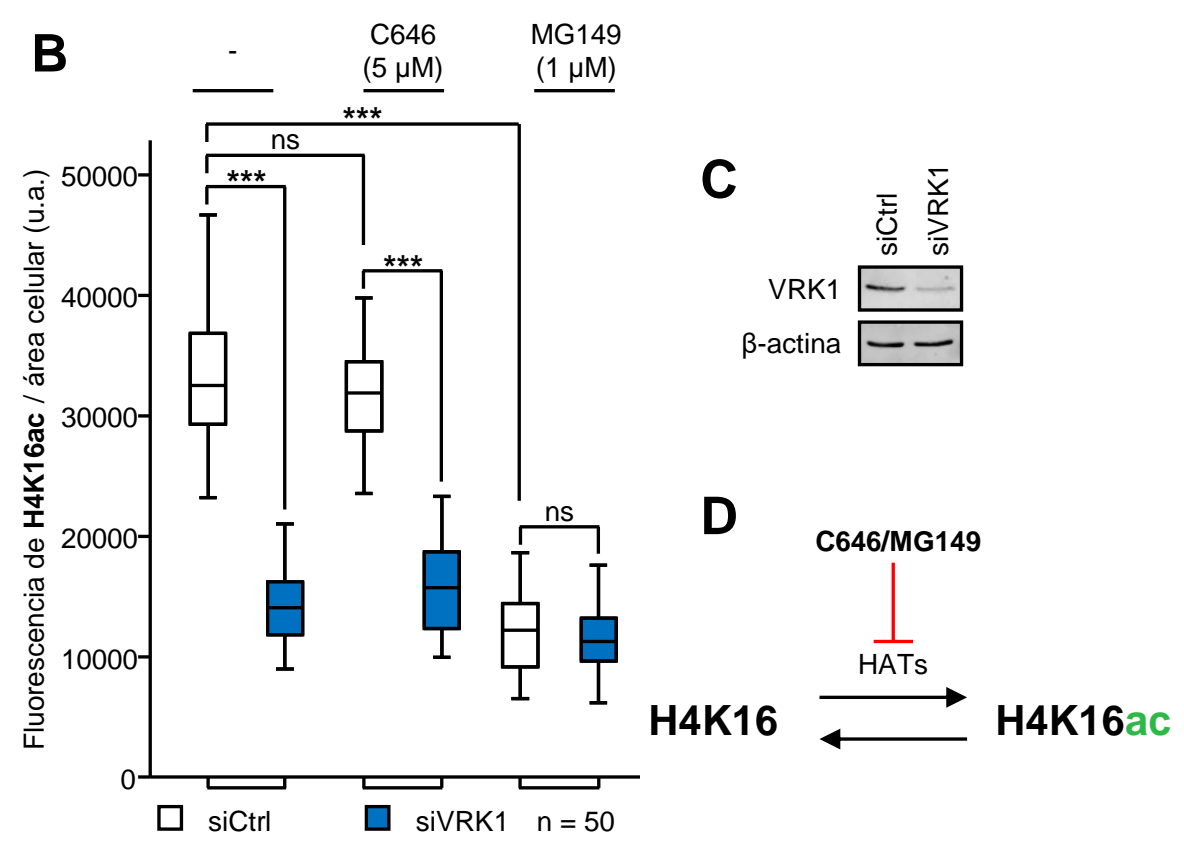

Figura 43: El inhibidor MG149 mimetiza el efecto de la ausencia de VRK1 sobre la H4K16ac. Se transfectaron las células A549 con 3 ARNi (siCtrl y una combinación de siVRK1-02 y -03) durante 96 horas y se retiró el suero del medio de cultivo (48 horas, 0,5\% FBS) antes de incubarlas con los inhibidores C646 $(5 \mu \mathrm{M})$ y MG149 $(1 \mu \mathrm{M})$ durante 24 horas. A continuación, se analizaron los cambios en los niveles de la H4K16ac mediante microscopía confocal. A. Acetilación de la H4K16 tras el silenciamiento de VRK1 y el tratamiento con C646 o MG149. B. Cuantificación de los niveles de la H4K16ac en respuesta a los inhibidores de HATs en presencia o ausencia de VRK1. La significación estadística se calculó con el test de Kluskal-Wallis y el post hoc T2 de Tamhane. C. Comprobación del silenciamiento de VRK1 mediante western blot. D. Esquema en el que se indica el grupo de enzimas diana de los inhibidores C646 y MG149. siCtrl: siC; siVRK1: siVRK1-02 + siVRK1-03. ns: no significativo; ${ }^{* *}, \mathrm{p}<0,001$.

\subsection{La ausencia de VRK1 altera el patrón de metilación de la lisina 4 de la histona $\mathrm{H} 3$}

El siguiente residuo que quisimos analizar fue la trimetilación de la H3K4 (H3K4me3), que se asocia, igual que la H4K16ac, con la relajación de la cromatina $(34,40)$. Tras silenciar el gen VRK1 y retirar el suero del medio de las células A549, evaluamos los cambios en esta metilación mediante microscopía confocal y western blot. Como ocurría con la H4K16ac, la ausencia de VRK1 redujo notablemente los niveles de la H3K4me3, lo cual demostramos por ambas técnicas (Figura 44). 


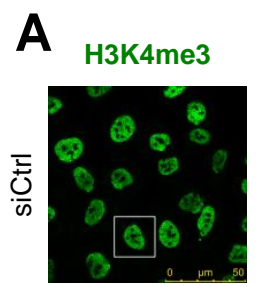

VRK1
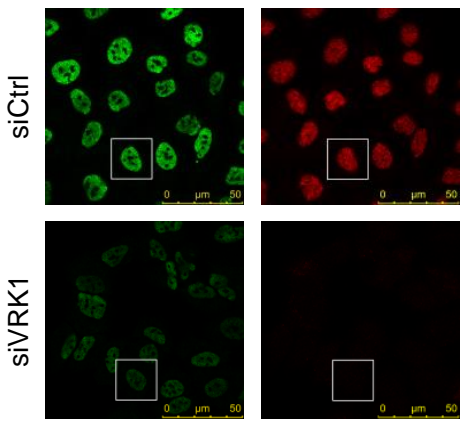

B

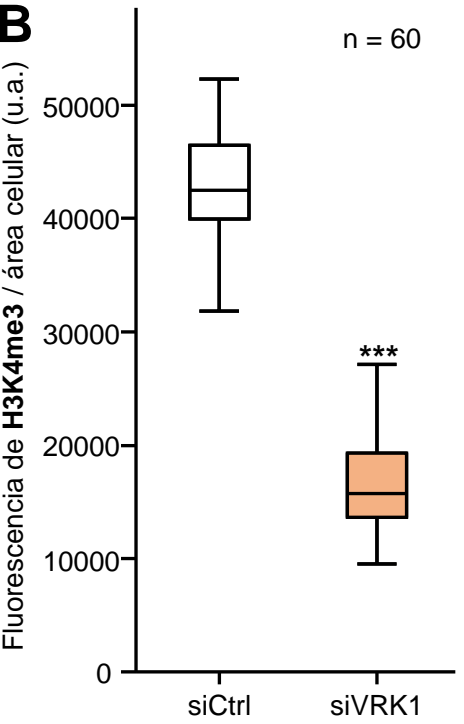

DAPI
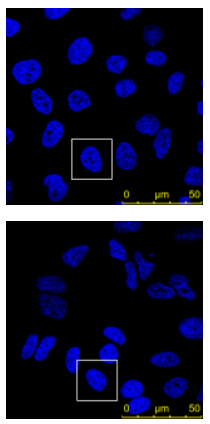

DETALLE
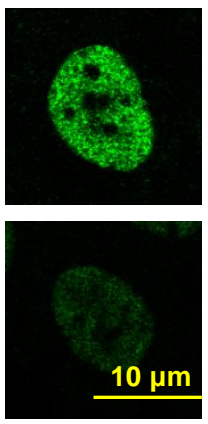

C

VRK1

$\beta$-actina

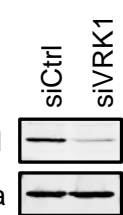

D

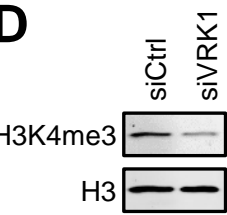

H3K4me3/H3 10,54

$\mathbf{E}$

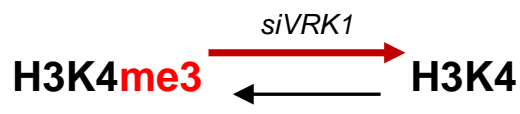

Figura 44: El silenciamiento de VRK1 conlleva una disminución considerable de los niveles de la trimetilación de la H3K4. Se silenciaron las células A549 con dos ARNi (siVRK102 y -03) y se retiró el suero del medio de cultivo $(0,5 \%$ FBS) durante 96 y 48 horas, respectivamente. A continuación, se evaluaron los niveles de la H3K4me3 mediante microscopía confocal y western blot. A. Cambios en la trimetilación de la H3K4 tras el silenciamiento de VRK1. B. Cuantificación de los niveles de la H3K4me3 en presencia o ausencia de VRK1. La significación estadística se calculó con el test de la $U$ de Mann-Whitney. C. Análisis de los niveles proteicos de VRK1 tras el silenciamiento génico. D. Extractos enriquecidos en histonas en los que se aprecian los cambios en los niveles de la trimetilación de la H3K4 en ausencia de VRK1. La cuantificación de las bandas representa el cociente $\mathrm{H} 3 \mathrm{~K} 4 \mathrm{me} / \mathrm{H} 3$ relativizado con respecto al control. E. Representación esquemática del efecto del silenciamiento de VRK1 sobre la H3K4me3. siCtrl: siC; siVRK1: siVRK1-02 + siVRK1-03. ${ }^{* * *}, \mathrm{p}<0,001$. 


\subsubsection{La inhibición de la metilación mediada por chaetocin mimetiza el efecto de la ausencia de VRK1 sobre la H3K4me3}

Para profundizar en la posible regulación de esta trimetilación, utilizamos los inhibidores de metiltransferasas y demetilasas de histonas chaetocin y JMJD2i, respectivamente $(227,228)$, y analizamos las variaciones en la $\mathrm{H} 3 \mathrm{~K} 4 \mathrm{me} 3$ en presencia y ausencia de VRK1 y de cada uno de estos inhibidores. Tras incubar las células A549 con el inhibidor chaetocin, observamos una clara disminución de los niveles de la H3K4me3 que no depende de la presencia de VRK1, pero que mimetiza el efecto del silenciamiento de esta quinasa. Por el contrario, el inhibidor JMJD2i impide que la H3K4 se demetile y, en consecuencia, los niveles de esta trimetilación aumentan tanto en presencia como en ausencia de VRK1 (Figura 45).

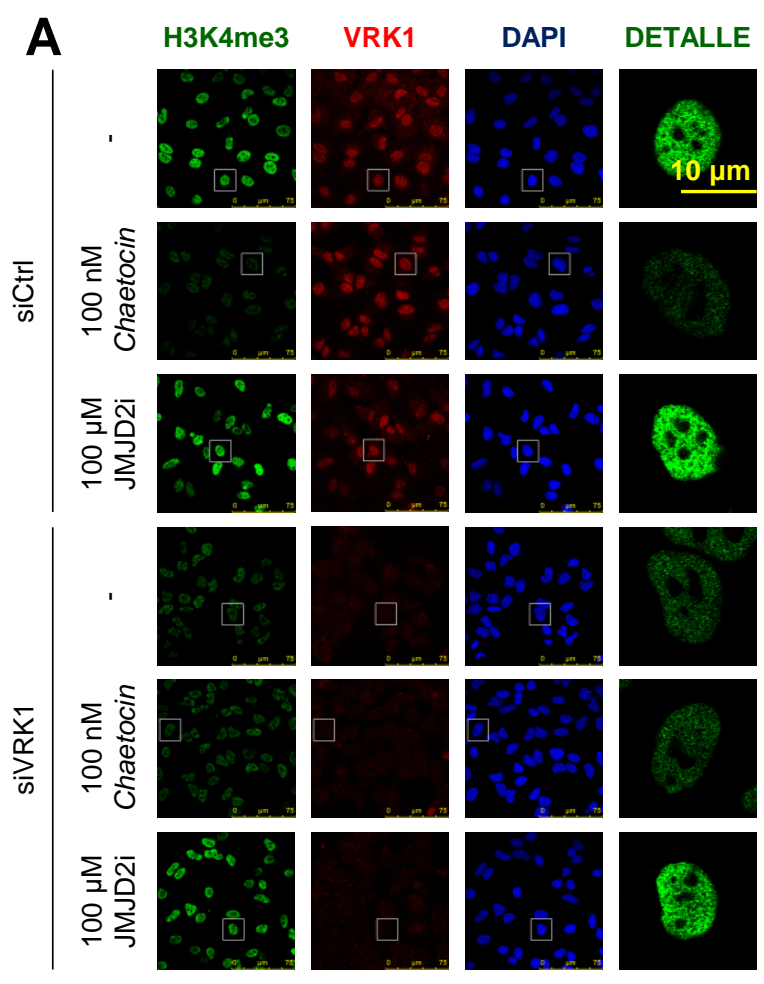




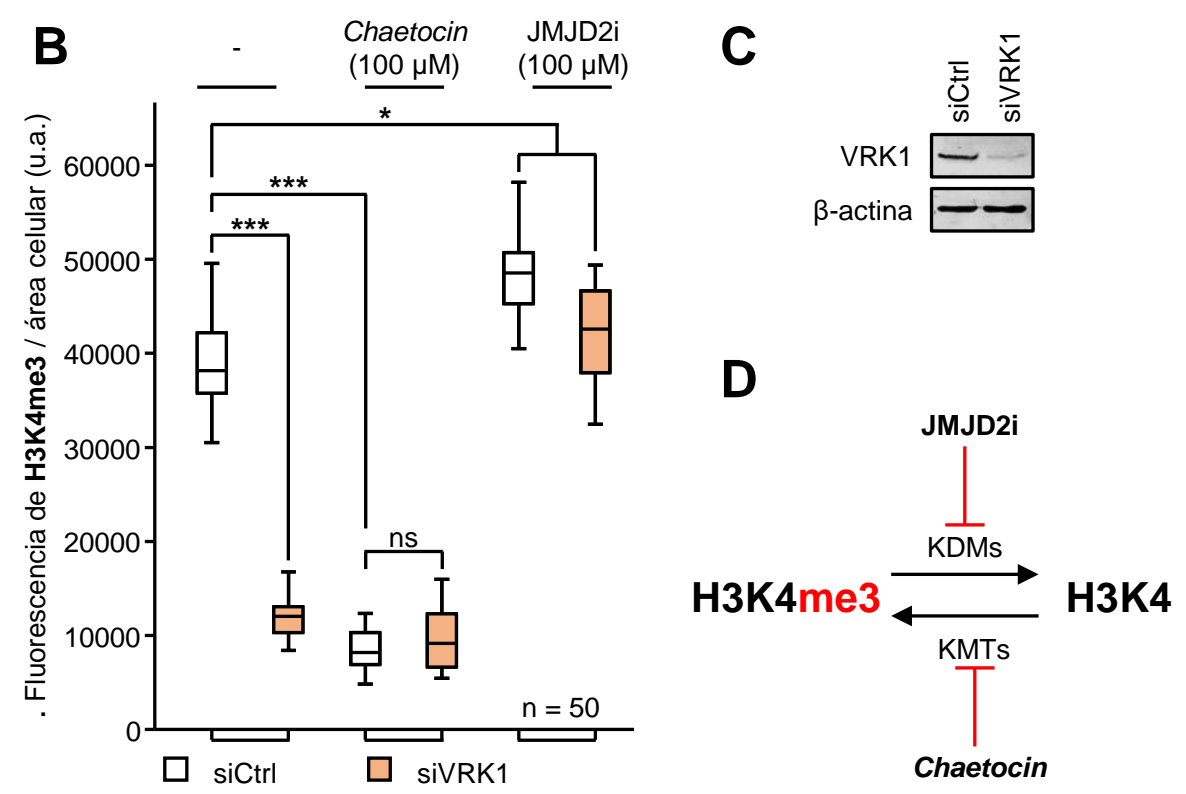

Figura 45: El silenciamiento de VRK1 y el tratamiento con el inhibidor chaetocin reducen significativamente los niveles de la H3K4me3. Se transfectaron las células A549 con 3 ARNi (siCtrl y una combinación de siVRK1-02 y -03) durante 96 horas y se retiró el suero del medio de cultivo (48 horas, 0,5\% FBS) antes de incubarlas con los inhibidores chaetocin (100 nM) y JMJD2i $(100 \mu \mathrm{M})$ durante 24 horas. Posteriormente, se analizaron los cambios en los niveles de la H3K4me3 mediante microscopía confocal. A. Trimetilación de la H3K4me3 tras el tratamiento con los inhibidores chaetocin y JMJD2i y el silenciamiento de VRK1. B. Cuantificación de los niveles de la H3K4me3 en presencia o ausencia de VRK1 y de los inhibidores correspondientes. La significación estadística se calculó con el test de Kluskal-Wallis y el post hoc T2 de Tamhane. C. Comprobación del silenciamiento de VRK1 mediante western blot. D. Esquema en el que se indica el grupo de enzimas diana de los inhibidores chaetocin y JMJD2i. siCtrl: siC; siVRK1: siVRK1-02 + siVRK1-03. ns: no significativo; ${ }^{*}, p<0,05 ;{ }^{* *}, p<0,001$.

\subsection{El silenciamiento de VRK1 modifica la dinámica de acetilación/metilación de la lisina 9 de la histona H3}

El último de los residuos que evaluamos fue la lisina 9 de la histona H3 y nos centramos en su acetilación (H3K9ac) o trimetilación (H3K9me3), dos modificaciones mutuamente excluyentes que favorecen la relajación o la compactación de la cromatina, respectivamente $(22,40,41)$. Por esta razón, quisimos determinar el patrón diferencial de ambas modificaciones en presencia o ausencia de la quinasa VRK1. Una vez analizados los niveles de ambas modificaciones mediante microscopía confocal y western blot, vimos que, de manera muy significativa, los niveles basales de acetilación disminuían y los de la trimetilación aumentaban (Figura 46), lo cual demuestra que la cromatina tiende a compactarse en ausencia de VRK1. Además, estos datos concuerdan con los obtenidos en experimentos anteriores en los 
que el silenciamiento de esta quinasa conllevaba una reducción considerable de otras marcas asociadas a la relajación de la cromatina como la H4K16ac (Figura 41) y la H3K4me3 (Figura 44).

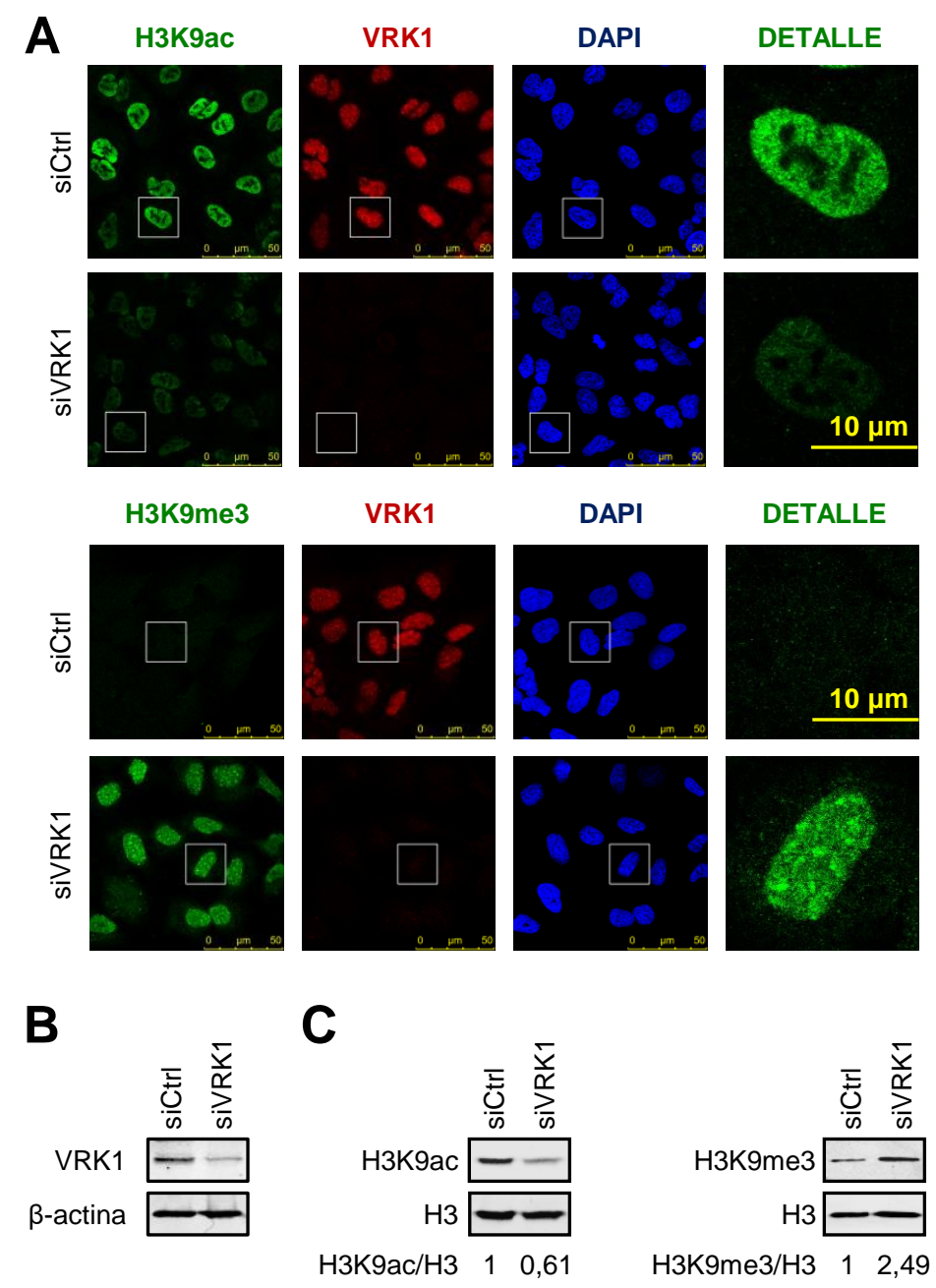



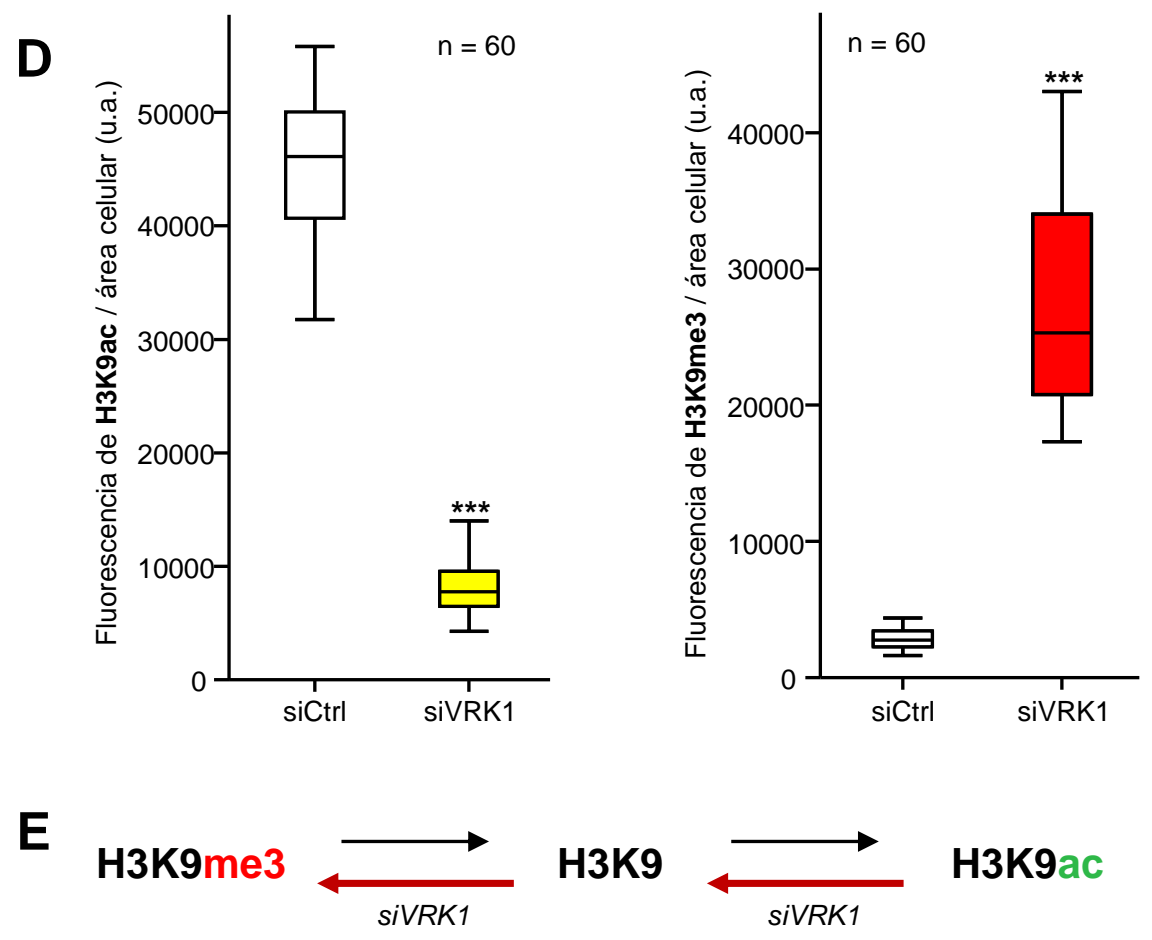

Figura 46: El silenciamiento de VRK1 conlleva el aumento de la metilación de la H3K9 y la disminución de la acetilación de este residuo. Se silenciaron las células A549 con dos ARNi (siVRK1-02 y -03) y se retiró el suero del medio de cultivo (0,5\% FBS) durante 96 y 48 horas, respectivamente. A continuación, se evaluaron los niveles de la acetilación y la trimetilación de la H3K9 mediante microscopía confocal y western blot. A. Acetilación y trimetilación de la H3K9 en presencia o ausencia de VRK1. B. Análisis de los niveles proteicos de VRK1 tras el silenciamiento génico. C. Extractos enriquecidos en histonas en los que se aprecian los cambios en los niveles de la H3K9ac y la H3K9me3 en ausencia de VRK1. La cuantificación de las bandas representa el cociente $\mathrm{H} 3 \mathrm{~K} 9 \mathrm{ac} / \mathrm{H} 3$ o $\mathrm{H} 3 \mathrm{~K} 9 \mathrm{me} 3 / \mathrm{H} 3$ relativizado con respecto al control. D. Cuantificación de los niveles de la H3K9ac y la H3K9me3 tras el silenciamiento de VRK1. La significación estadística se calculó con el test de la $U$ de Mann-Whitney. E. Representación esquemática del efecto del silenciamiento de VRK1 sobre las modificaciones covalentes de la H3K9. siCtrl: siC; siVRK1: siVRK1-02 + siVRK1-03. ${ }^{* * *}, p<0,001$.

\subsubsection{Los niveles de acetilación de la H3K9 aumentan tras el tratamiento con inhibidores de deacetilasas en presencia $y$ ausencia de VRK1}

Al igual que con la acetilación de la H4K16, quisimos estudiar el efecto de los inhibidores de deacetilasas entinostat y SAHA sobre la H3K9ac para determinar si alteraban la respuesta celular asociada al silenciamiento de VRK1. El tratamiento con estos inhibidores, al impedir la pérdida de la acetilación preexistente, supuso un aumento de los niveles de H3K9ac, más pronunciados en el caso de SAHA, tanto en presencia como en ausencia de VRK1 (Figura 47). Sin embargo, el silenciamiento de 
esta quinasa sí se asoció con una disminución de la fluorescencia asociada a la H3K9ac en las células que no se incubaron con ningún inhibidor, como se observa también en la figura 46 .

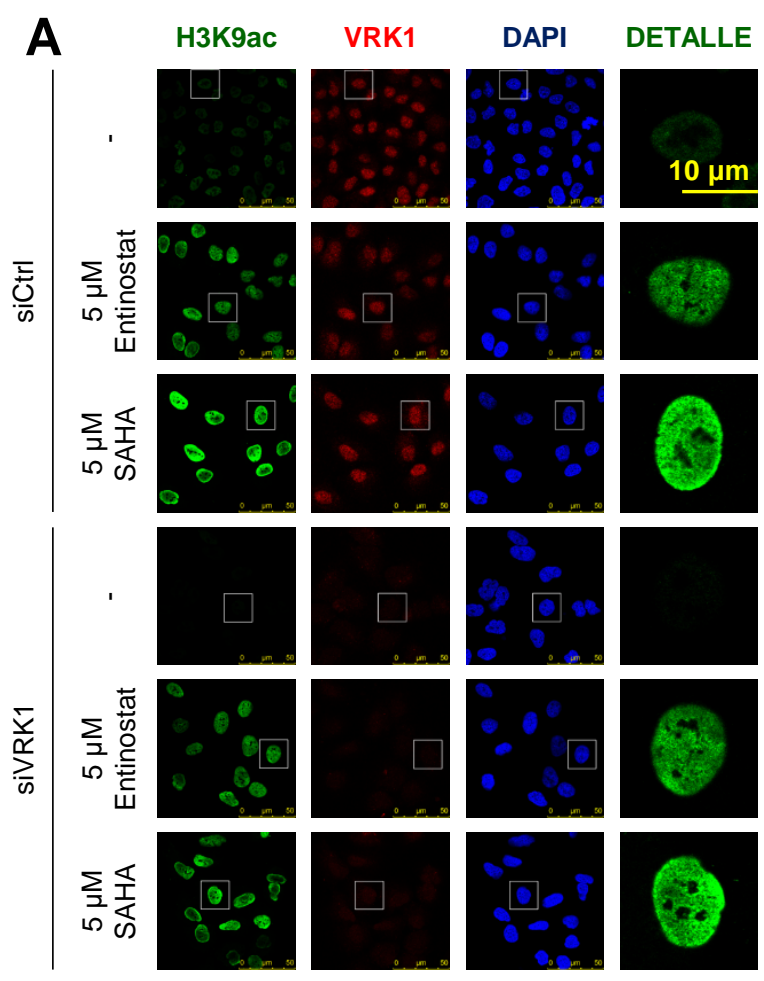




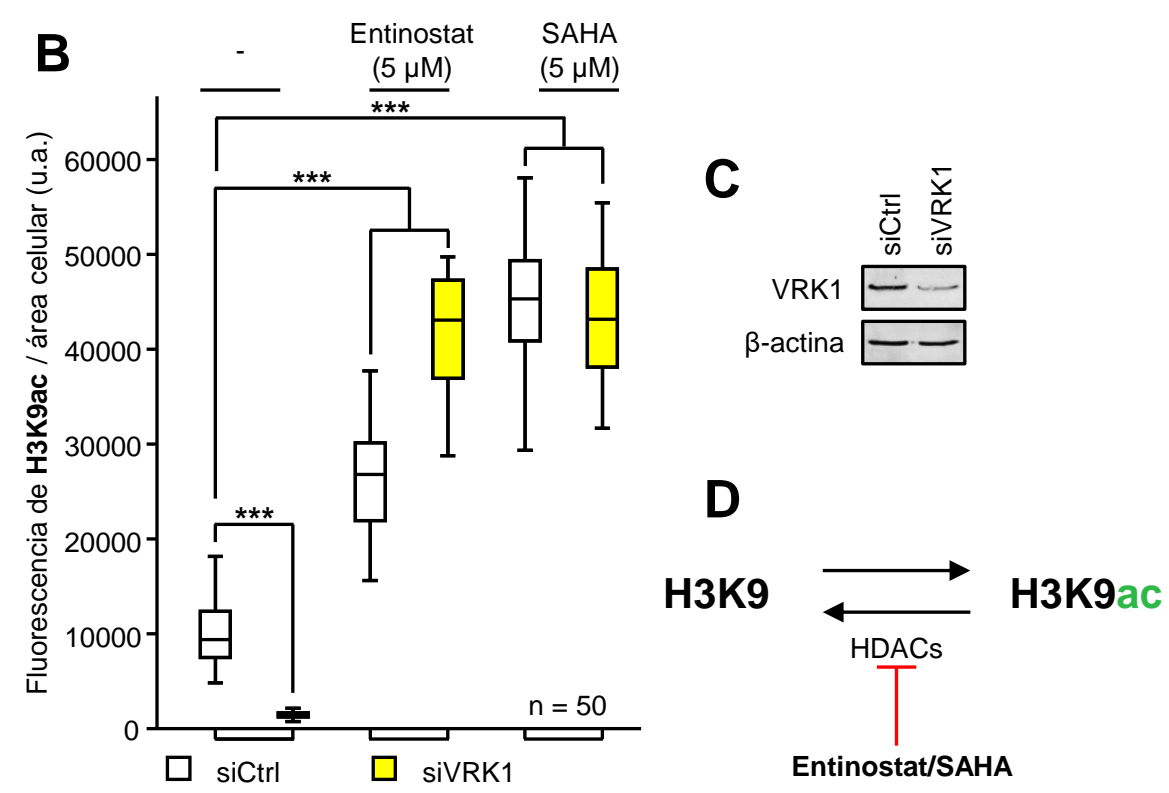

Figura 47: La inhibición de las deacetilasas mediada por entinostat y SAHA conlleva un aumento significativo de los niveles de la H3K9ac. Se transfectaron las células A549 con 3 ARNi (siCtrl y una combinación de siVRK1-02 y -03) durante 96 horas y se retiró el suero del medio de cultivo (48 horas, $0,5 \%$ FBS) antes de incubarlas con los inhibidores entinostat $(5 \mu \mathrm{M})$ y SAHA $(5 \mu \mathrm{M})$ durante 24 horas. Posteriormente, se analizaron los cambios en los niveles de la H3K9ac mediante microscopía confocal. A. Acetilación de la H3K9 en respuesta al tratamiento con los inhibidores de deacetilasas en presencia o ausencia de VRK1. B. Cuantificación de los niveles de la H3K9ac tras el silenciamiento de VRK1 y el tratamiento con entinostat o SAHA. La significación estadística se calculó con el test de Kluskal-Wallis y el post hoc T2 de Tamhane. C. Comprobación del silenciamiento de VRK1 mediante western blot. D. Esquema en el que se indica el grupo de enzimas diana de los inhibidores entinostat y SAHA. siCtrl: siC; siVRK1: siVRK1-02 + siVRK1-03. ${ }^{* * *}, p<0,001$.

\subsubsection{El silenciamiento de VRK1 reduce los niveles de acetilación de la H3K9 de manera similar a los inhibidores de HATs}

Siguiendo con la caracterización de los cambios en la acetilación de la H3K9 y tras evaluar el efecto de los inhibidores de deacetilasas, estudiamos el efecto de los dos inhibidores de HATs ya utilizados para la H4K16ac, C646 y MG149. Los niveles de la H3K9ac disminuyeron con ambos inhibidores, pero, de manera más drástica, en respuesta al tratamiento con $\mathrm{C646}$. Ahora bien, el silenciamiento de VRK1 redujo aún más los niveles de esta acetilación tanto en presencia como en ausencia de ambos inhibidores de HATs (Figura 48). 

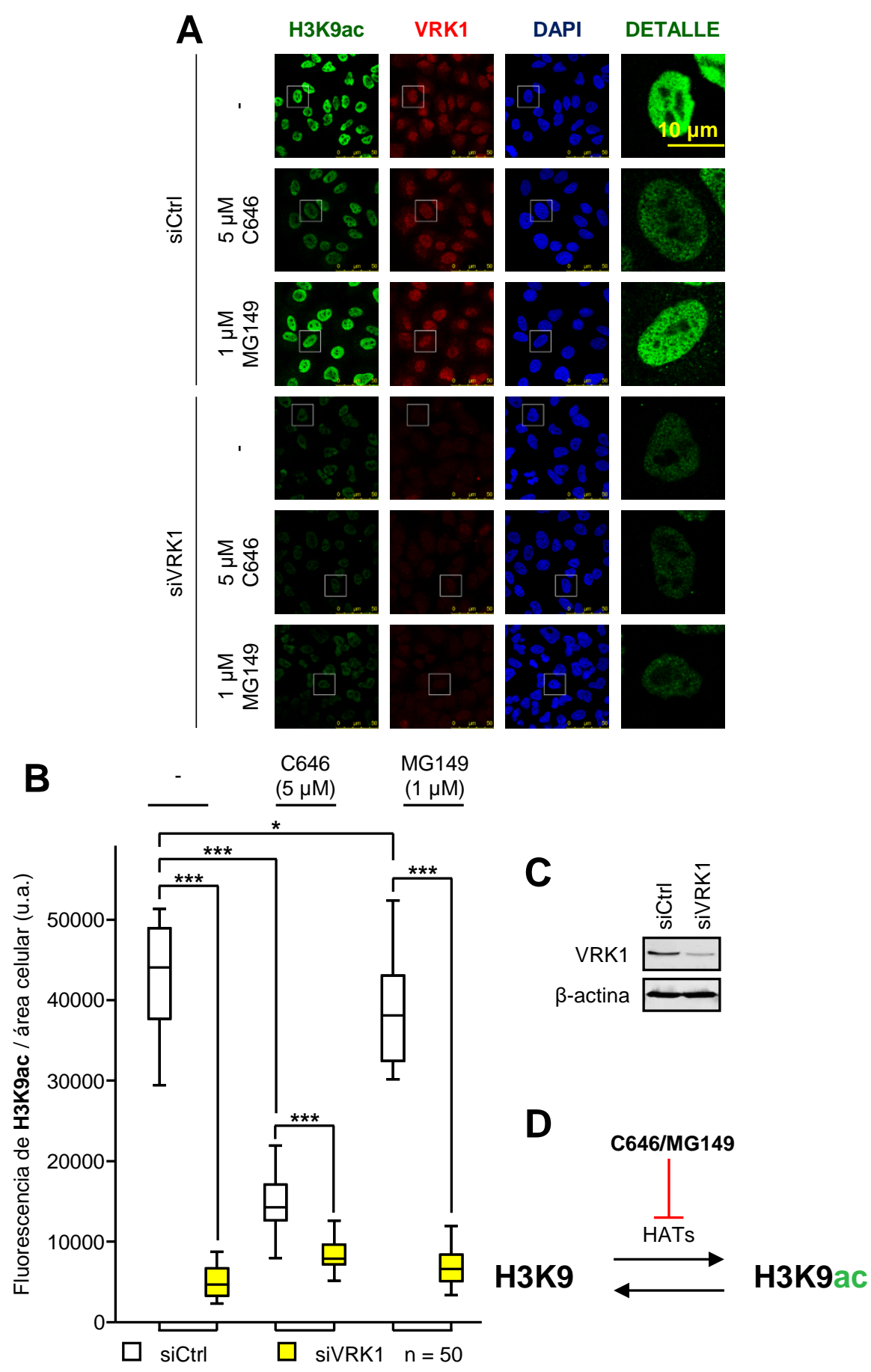
Figura 48: Tanto el silenciamiento de VRK1 como el tratamiento con los inhibidores C646 y MG149 reducen los niveles de acetilación de la H3K9. Tras silenciar la expresión génica de VRK1 (96 horas) y retirar el suero del medio de cultivo de las células A549 (48 horas, 0,5\% FBS), se incubaron con los inhibidores C646 $(5 \mu \mathrm{M})$ y MG149 $(1 \mu \mathrm{M})$ durante 24 horas y se evaluaron los niveles de la H3K9ac mediante microscopía confocal. A. Acetilación de la H3K9 tras la inhibición de HATs mediada por C646 y MG149 y el silenciamiento de VRK1. B. Cuantificación de los niveles de la H3K9ac en respuesta al tratamiento con C646 o MG149 tanto en presencia como en ausencia de VRK1. La significación estadística se calculó con el test de Kluskal-Wallis y el post hoc T2 de Tamhane. C. Análisis de los niveles proteicos de VRK1 tras el silenciamiento génico. D. Esquema en el que se indica el grupo de enzimas diana de los inhibidores C646 y MG149. siCtrl: siC; siVRK1: siVRK1-02 + siVRK1-03. * $p<0,05 ;{ }^{* * *}, p<0,001$.

\subsubsection{La inhibición de las demetilasas mediada por JMJD2i mimetiza el efecto del silenciamiento de VRK1 sobre la trimetilación de la H3K9}

Una vez analizado el efecto de los inhibidores de HATs y HDACs sobre la acetilación de la H3K9, quisimos evaluar también qué pasaba con la trimetilación de este residuo. Con este objetivo, comparamos el efecto del silenciamiento de VRK1 sobre la H3K9me3 en las células A549 con el de los inhibidores chaetocin y JMJD2i. Al contrario de lo que ocurría con la H3K4me3, los niveles de la H3K9me3 aumentaban en ausencia de la quinasa VRK1, un efecto similar al del inhibidor de demetilasas JMJD2i. Sin embargo, la trimetilación de la H3K9 disminuyó notablemente en respuesta al tratamiento con chaetocin y, aunque el silenciamiento de VRK1 contribuyó a aumentar los niveles de $\mathrm{H} 3 \mathrm{~K} 9 \mathrm{me} 3$ en este supuesto, éstos seguían siendo significativamente menores a los asociados a la ausencia de esta quinasa en células no tratadas con ninguno de los inhibidores (Figura 49). 

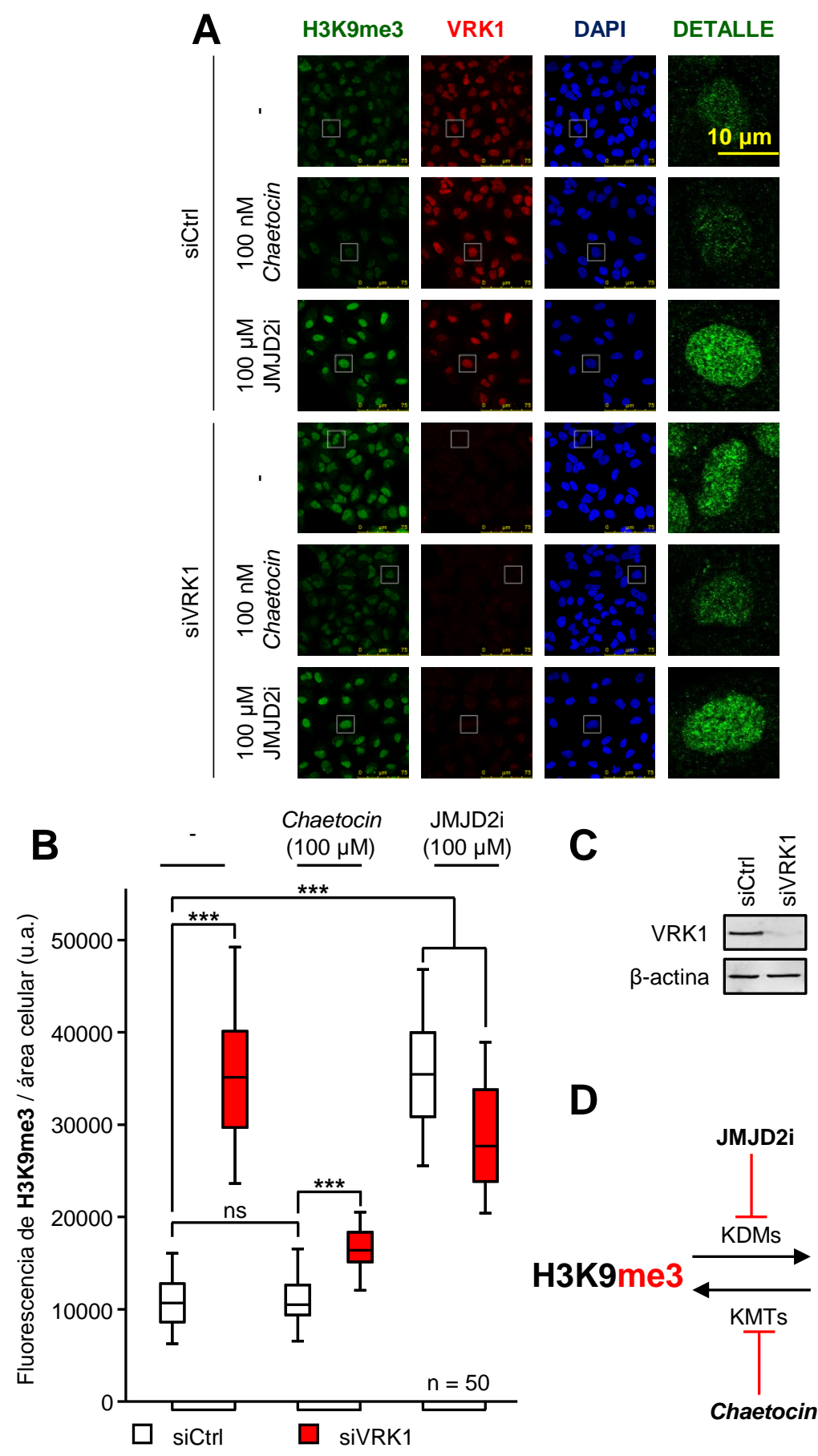

D

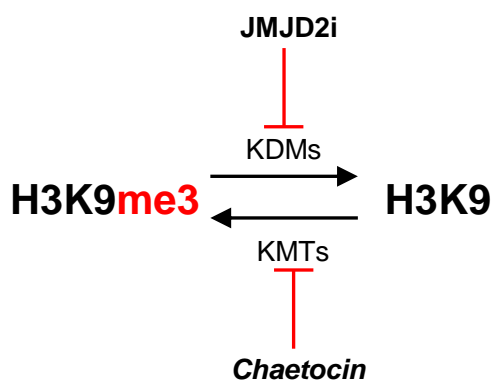


Figura 49: La inhibición de las demetilasas mediada por JMJD2i muestra el mismo efecto sobre la trimetilación de la H3K9 que el silenciamiento de VRK1. Se transfectaron las células A549 con 3 ARNi (siCtrl y una combinación de siVRK1-02 y -03) durante 96 horas y se retiró el suero del medio de cultivo (48 horas, 0,5\% FBS) antes de incubarlas con los inhibidores chaetocin $(100 \mathrm{nM})$ y JMJD2i $(100 \mu \mathrm{M})$ durante 24 horas. Posteriormente, se analizaron los cambios en los niveles de la H3K9me3 mediante microscopía confocal. A. Trimetilación de la H3K9 tras el tratamiento con chaetocin o JMJD2i y el silenciamiento de VRK1. B. Cuantificación de los niveles de la $\mathrm{H} 3 \mathrm{~K} 9 \mathrm{me} 3$ en respuesta al tratamiento con los inhibidores de metiltransferasas o demetilasas y a la presencia o ausencia de VRK1. La significación estadística se calculó con el test de Kluskal-Wallis y el post hoc T2 de Tamhane. C. Comprobación del silenciamiento de VRK1 mediante western blot. D. Esquema en el que se indica el grupo de enzimas diana de los inhibidores chaetocin y JMJD2i. siCtrl: siC; siVRK1: siVRK1-02 + siVRK103. ns: no significativo; ${ }^{* *}, \mathrm{p}<0,001$. 
Discusión 



\section{PAPEL DE VRK1 EN LA RESPUESTA AL DAÑO EN EL ADN CAUSADO POR LA COMBINACIÓN DE OLAPARIB Y RADIACIÓN IONIZANTE}

El mantenimiento de la integridad genómica de un organismo vivo depende, en gran medida, de la capacidad que tenga para reparar las lesiones que se producen constantemente en su ADN, cuyo origen puede ser endógeno o exógeno. En las células eucariotas, existen multitud de vías de señalización implicadas en la reparación del ADN que se engloban en la llamada respuesta al daño génico (DDR), las cuales, a pesar de estar estrictamente reguladas, no son infalibles. Los defectos en estos mecanismos de reparación en el ADN están íntimamente relacionados con una amplia variedad de aberraciones genómicas, incluyendo mutaciones puntuales y translocaciones cromosómicas, así como la ganancia o pérdida de regiones cromosómicas o cromosomas enteros, que, en algunos casos, inducen cambios en la fisiología celular asociados directamente con la progresión tumoral (237).

Ahora bien, la inactivación funcional de los mecanismos implicados en DDR no sólo promueve la transformación celular y el inicio de la carcinogénesis, sino que también vuelve a las células cancerosas más dependientes de las vías de reparación del ADN que siguen activas, lo que las hace más susceptibles a la terapia antitumoral (238).

La quimioterapia y la radiación ionizante se utilizan para el tratamiento del cáncer por su capacidad para generar lesiones en el ADN de las células tumorales (239). Sin embargo, la efectividad de estos tratamientos no radica exclusivamente en la acumulación de daño génico. Muchos tipos de cáncer muestran defectos en la DDR que impiden la correcta reparación del ADN, favorecen la aparición de inestabilidad genómica en el tumor y alteran las relaciones entre las células tumorales y su microambiente (237).

Una alternativa terapéutica a los tratamientos convencionales es la utilización de inhibidores específicos frente a componentes clave en la DDR, los cuales, en combinación con los fallos en las vías de reparación propios de las células tumorales y con agentes causantes de daño génico, sensibilizan al tumor y favorecen el efecto citotóxico de la quimioterapia (239). Dentro de este grupo de inhibidores destacan los dirigidos frente a PARP, entre los que se encuentra el olaparib, objeto de estudio en esta tesis doctoral. 


\subsection{El olaparib sensibiliza a las células cancerosas al tratamiento con radiación ionizante y genera una respuesta independiente de p53}

Estudios previos hablan del uso combinado del olaparib con fuentes exógenas de daño génico como la radiación ionizante, ya que este fármaco quimioterapéutico bloquea el mecanismo principal de reparación del daño oxidativo generado por la IR (BER) y, en consecuencia, promueve la muerte celular tumoral por acumulación de lesiones en el $\operatorname{ADN}(125,126)$. En nuestro caso, quisimos caracterizar el efecto sinérgico de ambos tratamientos sobre líneas celulares tumorales con distintos fondos genéticos y utilizando como marcadores dos proteínas implicadas en la reparación de roturas de doble cadena en el ADN (DSBs): la fosforilación de la histona H2AX ( $\mathrm{H} 2 \mathrm{AX})$, asociada a la respuesta temprana al daño e independiente del mecanismo de reparación que se active, y 53BP1, esencial en la reparación por unión de extremos no homólogos.

El olaparib se utiliza en el tratamiento del cáncer de mama y de ovario con mutaciones en $B R C A 1 / 2$, lo que nos llevó inicialmente a caracterizar el efecto combinado de este fármaco con la radiación en una línea de carcinoma de mama, MDA-MB-231 (triple negativo). Los resultados obtenidos muestran que el tratamiento exclusivo con concentraciones crecientes de olaparib tiene un efecto dosis-dependiente sobre el número de focos de $\mathrm{YH} 2 \mathrm{AX}$ y 53BP1, lo que significa que este agente quimioterapéutico favorece la acumulación de daño en el ADN que tiene que ser reparado. Lo mismo ocurre en el caso de la radiación ionizante, donde dosis más bajas (0,5-1 Gy) generan un menor número de focos de reparación que las más altas (3 Gy). Posteriormente, el análisis de la combinación de ambos tratamientos reveló que las combinaciones de la concentración más alta de olaparib $(10 \mu \mathrm{M})$ con dosis más bajas de radiación, tanto 0,5 como 1 Gy, eran capaces de formar el mismo número de focos de $\mathrm{YH} 2 \mathrm{AX}$ y 53BP1 que la dosis de radiación más alta ( $3 \mathrm{~Gy}$ ). Además, el uso de $5 \mu \mathrm{M}$ de olaparib y 1 Gy de IR, que reduce a la mitad y a una tercera parte las dosis más elevadas de ambos tratamientos, respectivamente, permite generar el mismo número de roturas en el ADN que los tratamientos con este inhibidor de PARP y con la radiación por separado. Este descubrimiento es relevante desde el punto de vista clínico, ya que el uso del olaparib y de otros inhibidores de la DDR en distintos tumores beneficia significativamente al paciente, pero conlleva la aparición de efectos secundarios debido a su administración sistémica. Por esta razón, la posibilidad de reducir las dosis y conseguir generar la misma cantidad de 
daño génico en las células tumorales permitiría mejorar la calidad de vida de los enfermos de cáncer.

Para evaluar que este efecto es independiente de la línea celular, realizamos el mismo tipo de experimentos en dos líneas tumorales de cáncer de pulmón, A549 (TP53 +/+) y H1299 (TP53 -/-). Estas dos nuevas líneas nos permitieron comparar el efecto de la combinación de olaparib e IR en el contexto de la presencia o ausencia de p53, dado que la activación de este factor de transcripción mediada por daño génico pone en marcha mecanismos celulares de protección como la parada del ciclo o, si el daño es muy severo, la entrada de las células en apoptosis o senescencia (223). En ambas líneas, la combinación de olaparib (5 $\mu \mathrm{M})$ e IR (1 Gy) mostró un efecto sinérgico sobre la formación de focos de $\mathrm{YH} 2 \mathrm{AX}$ y 53BP1, al igual que ocurría con las células MDA-MB-231, lo que implica que el reclutamiento de $\mathrm{YH} 2 \mathrm{AX}$ y 53BP1 al sitio de la lesión en respuesta al tratamiento combinado no depende de la línea celular ni del estatus de p53. Esto refuerza la idea de que el olaparib sensibiliza a las células tumorales al tratamiento con radiación ionizante y abre el abanico de tumores en los que podría implantarse esta estrategia terapéutica.

\subsection{La quinasa VRK1 regula la respuesta al daño génico derivada del tratamiento con olaparib e IR}

La respuesta al daño en el $A D N$ es un proceso altamente coordinado capaz de detectar, señalizar y reparar de manera eficaz las lesiones en el genoma en función de su naturaleza (52). Durante los últimos años, numerosos trabajos han puesto de manifiesto el papel de la quinasa VRK1, cuya localización es principalmente nuclear, en las distintas etapas de la DDR $(85,86,101,180)$.

Como se ha comentado anteriormente en esta tesis, el primer evento que tiene que ocurrir tras la rotura del ADN es la relajación de la cromatina que se encuentra alrededor de la zona dañada (69). Esto conlleva la aparición de una estructura abierta y accesible que se caracteriza, principalmente, por un aumento de la acetilación de las histonas adyacentes, incluyendo la acetilación de la lisina 16 de la histona $\mathrm{H} 4$.

Una de las funciones de la quinasa VRK1 es la regulación de la acetilación en respuesta al daño génico inducido por radiación ionizante (85). Por esta razón, quisimos determinar si la acetilación de la H4K16 variaba en respuesta al daño provocado por olaparib y/o IR, y si estos cambios estaban regulados por VRK1. EI tratamiento con radiación u olaparib por separado aumentaba significativamente los niveles de la H4K16ac de manera dosis-dependiente y la combinación de ambos 
también condujo a un incremento considerable de estos niveles. Sin embargo, el silenciamiento de $V R K 1$ reduce la acetilación de la H4K16 en respuesta al daño génico. Esto apunta a que la regulación de esta modificación covalente en la histona H4 depende de esta quinasa de la cromatina, pero tiene que ser a través de un mecanismo indirecto, ya que VRK1 carece de actividad acetiltransferasa.

En el contexto del daño en el ADN, la acetilación de la H4K16 depende de MOF y Tip60, y su actividad puede modularse por fosforilación $(71,78)$. Por tanto, es posible que VRK1 esté regulando a estas acetiltransferasas de la misma manera. Introduciendo la secuencia de ambas enzimas en la herramienta de predicción GPS 3.0 (group-based prediction system; http://gps.biocuckoo.org/), encontramos diversos residuos candidatos a ser fosforilados por esta quinasa en ambas HATs.

En el caso de MOF, convendría evaluar tanto in vitro como in vivo la fosforilación de los dos residuos predichos, las serinas 244 y 428, para determinar la posible interconexión entre VRK1 y los niveles de acetilación de la H4K16. A su vez, otros residuos de fosforilación de esta acetiltransferasa, que según el programa de predicción no serían diana de VRK1, están relacionados con la respuesta al daño en el ADN y habría que estudiarlos más a fondo. Estos residuos son las serinas 37 y 42 , que se encontraron en un análisis multiómico del daño en el ADN generado por radiación UV (240), y la treonina 392, que se fosforila vía ATM y es importante para la reparación del daño génico en las fases S/G2 del ciclo celular $(71,241)$.

Por su parte, Tip60 también tiene residuos potenciales de fosforilación según el programa de predicción, que varían en función de la isoforma de esta acetiltransferasa. En primer lugar, sería interesante estudiar la serina 6, que es la que presenta mayor puntuación, y, a continuación, la serina 422 y la treonina 191, presentes en todas las isoformas descritas para esta HAT. Merece la pena destacar a la treonina 191, dado que su fosforilación mediada por las MAP quinasas p38 (p38MAPKs) en respuesta a radiación ionizante promueve la vía apoptótica al acetilar a p53 y activar a PUMA $(242,243)$, situando a este residuo en el contexto de la DDR. Además, convendría analizar también la serina 123 debido a la importancia que tiene esta fosforilación sobre su actividad catalítica (244).

Junto con la acetilación de histonas, la fosforilación de la histona H2AX en la serina 139 ( $\mathrm{YH} 2 \mathrm{AX})$ y el reclutamiento del complejo MRN son esenciales para la detección del daño, la protección de los extremos generados tras la rotura y la amplificación de la señal en respuesta al daño en el $\operatorname{ADN}(54,68,82)$. Estudios previos han demostrado que la quinasa humana VRK1 se activa en respuesta a la radiación 
ionizante y fosforila, al igual que las quinasas de la familia PIKK (ATM, ATR y DNA$P K c s)$, a la histona H2AX. Además, esta quinasa es necesaria para que se formen correctamente los focos de $\mathrm{yH} 2 \mathrm{AX}(85,101)$. Por este motivo, analizamos el efecto del silenciamiento de VRK1 sobre la formación de estos focos tras la inducción de daño génico con olaparib y/o IR. Tanto la combinación de ambos tratamientos como su uso por separado contribuían a la acumulación de $\mathrm{yH} 2 \mathrm{AX}$ en las zonas dañadas e incrementaban el número de focos de manera notable. Sin embargo, la ausencia de VRK1 afectaba significativamente a la formación de focos de $\mathrm{YH} 2 \mathrm{AX}$ en respuesta a olaparib, IR y a su combinación, lo que quiere decir que el papel que juega VRK1 en la fosforilación y acumulación de $\mathrm{yH} 2 \mathrm{AX}$ en las regiones adyacentes a la región dañada es independiente del tipo de daño.

Tanto ATM como VRK1 fosforilan en la serina 343 a NBS1, uno de los componentes del complejo MRN $(86,87)$. En el caso de VRK1, esta fosforilación no depende de ATM e impide la ubiquitinación y posterior degradación de NBS1 vía proteasoma (86). Dado que el silenciamiento de VRK1 también interfiere en la formación de focos de NBS1 tras la inducción de daño génico con radiación ionizante, quisimos determinar la respuesta celular tras el tratamiento con olaparib y/o IR sobre la formación de focos de NBS1 en presencia o ausencia de esta quinasa de la cromatina. Los resultados obtenidos muestran que el silenciamiento de VRK1 altera la formación de focos de $\mathrm{YH} 2 \mathrm{AX}$ y NBS1 de manera similar en respuesta al tratamiento con olaparib e IR, por separado, o a su combinación, lo que sitúa a VRK1 en las primeras etapas de la respuesta al daño, no sólo por su implicación en la relajación de la estructura de la cromatina, sino también por la regulación de algunas de las proteínas sensoras claves en la reparación.

Debido al efecto que tiene la ausencia de VRK1 sobre la acetilación de la histona H4 y la fosforilación de H2AX y NBS1 tras la inducción de daño génico con olaparib y/o IR, era de esperar que afectase a otras proteínas que participan en etapas más avanzadas de la respuesta. Elegimos a 53BP1 por dos principales motivos. En primer lugar, por el papel que juega VRK1, por una parte, en la formación de focos de 53BP1 en respuesta a radiación ionizante y al tratamiento con doxorrubicina $(101,180)$, y, por otra, en la fosforilación de las serinas 25 y 29 de 53BP1 tras la inducción de daño génico con IR (101). El segundo motivo deriva del hecho de que hemos estudiado el efecto del silenciamiento de VRK1 sobre la relajación de la cromatina y la formación de focos de $\mathrm{YH} 2 \mathrm{AX}$ y NBS1 asociadas al daño génico en células que no se están dividiendo, como es el caso de las neuronas o las células madre, donde las roturas de doble cadena se reparan preferentemente por unión de extremos no homólogos. En 
consecuencia, elegimos a 53BP1, una proteína clave en este mecanismo de respuesta a las DSBs.

El análisis del silenciamiento de VRK1 sobre la formación de focos de 53BP1 asociados al tratamiento con olaparib y/o IR puso de manifiesto que esta quinasa de la cromatina también interfiere en la reparación de las DSBs causadas por este fármaco quimioterapéutico, la IR y su combinación. Con estos datos, podemos demostrar que VRK1 se activa en respuesta a diferentes tipos de daño, independientemente del estado de división de las células, y participa en distintas etapas de la reparación.

Como hemos visto hasta ahora, las quinasas VRK1 y ATM son indispensables para el correcto desarrollo de la DDR y, en algunos casos, redundantes en sus funciones. Sin embargo, la activación de VRK1 es previa a la de ATM en respuesta al daño en el $\operatorname{ADN}(85,86,101)$, con lo que la inhibición de ATM debería mimetizar el efecto del silenciamiento de VRK1. Evaluamos esta hipótesis tratando las células con un inhibidor específico de ATM, KU55933, y vimos cómo la formación defectiva de los focos de $\mathrm{YH} 2 \mathrm{AX}$ y 53BP1 tras el tratamiento con olaparib en ausencia de VRK1 se asemejaba al de la inhibición de ATM. Además, se sabe que la activación de ATM es posterior a la relajación de la cromatina (51) y que VRK1 modula los niveles de acetilación de la H4K16ac (85), por lo que quisimos demostrar que esta acetilación no se veía afectada por la inhibición de ATM o la ausencia de esta quinasa. En respuesta a olaparib, las células tratadas con el inhibidor KU55933 o las que carecían de ATM mostraban un aumento significativo de los niveles de la H4K16ac, al contrario de lo que ocurría con aquellas donde la expresión génica de VRK1 se había silenciado. Estos resultados indican, por tanto, que VRK1 participa en la relajación local de la cromatina como consecuencia del daño génico y se activa antes que ATM. De hecho, basándonos en la posibilidad de que VRK1 fosforile a Tip60 y module así la acetilación de la H4K16, esta quinasa podría regular indirectamente la activación de ATM, que depende de la acetilación de la lisina 3016 mediada por esta acetiltransferasa (75).

Además de la implicación que tiene la quinasa humana VRK1 en las distintas etapas de la respuesta al daño en el ADN provocado por el olaparib y/o la IR, nos preguntamos si la respuesta mediada por esta quinasa dependía de p53 y/o ATM. EI factor de transcripción p53 es un supresor tumoral que protege a las células del daño génico al mediar la parada de ciclo y la muerte celular. Al obtener resultados similares en líneas TP53 +/+ (A549) y TP53 -/- (H1299), podemos decir que la respuesta celular al daño génico causado por la combinación de olaparib e IR no depende de este 
factor de transcripción, lo que amplía el rango de tumores en los que podría utilizarse la combinación olaparib/IR y los futuros inhibidores de VRK1.

Por su parte, ATM es una quinasa que actúa a distintos niveles de la DDR y es clave en la reparación del ADN, al igual que VRK1. Además, se sabe que el tratamiento con olaparib sensibiliza a tumores que carecen de ATM $(129,130)$. Los datos que se extraen de nuestros experimentos nos indican que el silenciamiento de VRK1 interfiere en la reparación del ADN en líneas que carecen de ATM y el hecho de que VRK1 preceda a la quinasa ATM en la respuesta permitiría utilizar inhibidores específicos de VRK1 en combinación con olaparib e IR en tumores $A T M+/+$.

\subsection{El desarrollo de inhibidores de VRK1 para su utilización en tratamientos combinados con olaparib e IR}

Por su efecto sobre la relajación local en la cromatina y en etapas concretas de la reparación del ADN, podemos decir que VRK1 juega una doble función en la DDR, lo que convierte a esta quinasa en una potencial diana terapéutica. Además, el silenciamiento de VRK1 no sólo afecta a la respuesta al daño génico, sino que también interfiere en la proliferación celular, de tal forma que, en caso de utilizarse en el tratamiento contra el cáncer, favorecería la reducción del tamaño del tumor y el incremento de la inestabilidad genómica. Por tanto, basándonos en la implicación de VRK1 en la progresión del ciclo celular y la respuesta al daño en el ADN, la inhibición de esta quinasa, en combinación con fuentes exógenas de DSBs, conllevaría la acumulación de mutaciones en las células madre tumorales, y promovería la activación de los programas de muerte celular en estas células o, en su defecto, las haría más susceptibles a la inmunoterapia $(245,246)$.

Muchos tumores tienen altos niveles de VRK1 asociados con un mal pronóstico, ya que facilitan la proliferación de las células que lo componen $(157,158,190)$, la formación de metástasis (191) y la resistencia al daño en el $\operatorname{ADN}(101,180)$ debido a la activación de las rutas de señalización y reparación del ADN en la cromatina (185) y a las respuestas celulares mediadas por p53 $(147,151,156,167,168)$. En consecuencia, la ausencia de VRK1 contribuiría a la disminución de la tasa proliferativa de las células tumorales e impediría la activación de la DDR.

En base a los resultados obtenidos, que apoyan la idea de que el silenciamiento de VRK1 sensibiliza a las células tumorales a los tratamientos que causan daño en el ADN, podemos afirmar que la ausencia de esta quinasa facilita la acción antitumoral del olaparib y/o la radiación ionizante. Por tanto, el desarrollo de inhibidores de VRK1 
abriría las puertas a nuevas estrategias terapéuticas de letalidad sintética en combinación con inhibidores de PARP como el olaparib y la IR, que contribuiría a reducir las dosis de los tratamientos actuales y, en consecuencia, su toxicidad.

\section{IR

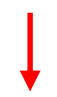

Especies reactivas de oxígeno (ROS)

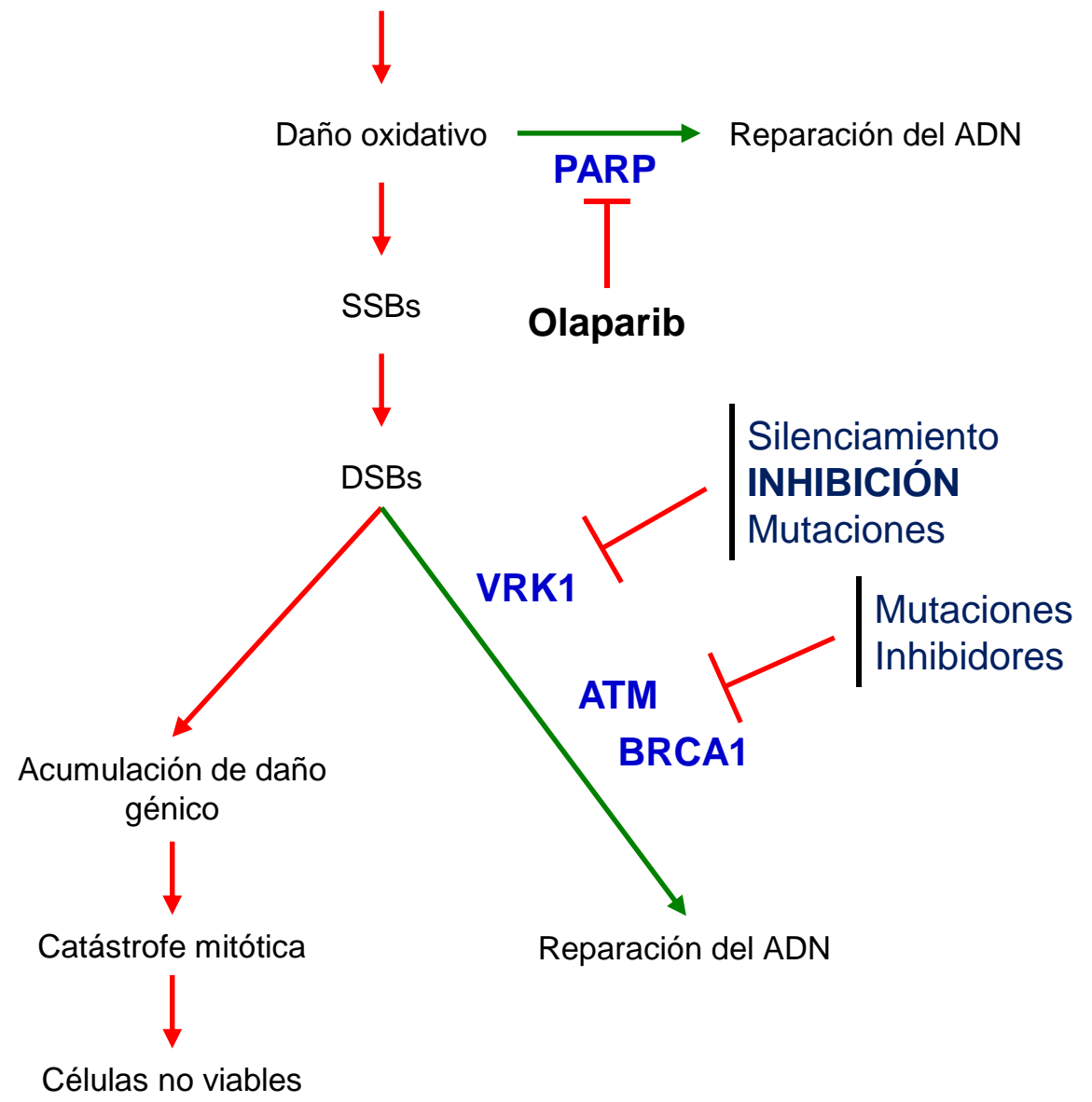

Figura 50: Diagrama que muestra las distintas etapas de la respuesta al daño en el ADN inducida por IR y como se ven alteradas por inhibidores específicos de proteínas clave de la DDR. Se destaca en mayúsculas el papel que tendría la inhibición de VRK1 en este contexto.

El dominio catalítico de VRK1 presenta una serie de características atípicas (148) que lo vuelven insensible a otros inhibidores de serina/treonina quinasas, como ha quedado demostrado mediante ensayos de interacción $(247,248)$ y de auto- y 
transfosforilación (217). Hasta la fecha, se han evaluado dos inhibidores de esta quinasa, la luteolina y el ácido ursólico. La luteolina es un flavonoide natural con un alto poder antioxidante que se ha visto que inhibe la autofosforilación de VRK1 y la fosforilación de BAF mediada por esta quinasa. A su vez, promueve la parada del ciclo celular y reduce la viabilidad celular, favoreciendo la apoptosis (218). Por su parte, el ácido ursólico, también presente en plantas, inhibe la inflamación y promueve la autofagia. Además, se ha visto que contribuye a la acumulación de daño génico al inhibir a VRK1 y muestra un efecto sinérgico con algunos agentes quimioterapéuticos causantes de lesiones en el ADN (219). Sin embargo, y a pesar de que ambos compuestos son capaces de interaccionar de manera específica con VRK1, las concentraciones necesarias para inhibir significativamente su actividad autocatalítica y de fosforilación de sustrato son muy elevadas, del rango micromolar, lo que incrementa el riesgo de inhibición cruzada con otras quinasas y de causar efectos secundarios en el paciente en caso de utilizarlas en tratamiento (185). Por tanto, es importante seguir trabajando en el desarrollo de nuevos inhibidores de VRK1 que permitan su uso a concentraciones tolerables para los pacientes y con un efecto contrastado sobre su actividad quinasa.

Como conclusión a este apartado, podemos decir que el silenciamiento de VRK1 altera la respuesta al daño en el $A D N$ a distintos niveles tras el tratamiento con olaparib y/o IR en células que no se están dividiendo. Además, la inhibición de esta quinasa mediada por compuestos específicos podría utilizarse en terapias combinadas con olaparib e IR en diferentes tipos de cáncer, independientemente del estado mutacional de p53 o ATM. Por último, los fallos en la DDR asociados a la inhibición de VRK1 favorecen la acumulación de daño génico en las células tumorales, lo que las conduciría a la muerte celular o las haría más inmunogénicas y/o susceptibles a nuevos enfoques terapéuticos basados en la inmunoterapia. 


\section{EFECTO DEL INHIBIDOR CHAETOCIN EN LA REGULACIÓN DEL CICLO CELULAR Y LA RESPUESTA AL DAÑO EN EL ADN}

Las distintas funciones biológicas del inhibidor chaetocin, un metabolito aislado de hongos del género Chaetomium, lo convierten en un potencial agente antitumoral. Entre ellas, cabe destacar la inhibición de las metiltransferasas (227), la generación de estrés oxidativo (230), el bloqueo del ciclo celular en G2/M y la inducción de apoptosis $(229,249)$. En este trabajo se ha abordado la implicación de este inhibidor en la regulación del ciclo celular y de la respuesta al daño en el ADN en el contexto de la línea celular U2OS.

\subsection{Consecuencias del tratamiento con los inhibidores chaetocin y JMJD2i sobre la regulación del ciclo celular}

En primer lugar, para verificar la efectividad del tratamiento con el inhibidor chaetocin, evaluamos los niveles de la trimetilación de la H3K9 (H3K9me3), en comparación con los de un inhibidor de demetilasas de la subfamilia JMJD2 (JMJD2i). Como cabía esperar, la fluorescencia asociada a la H3K9me3 disminuyó significativamente en presencia de chaetocin, resultados que demuestran la capacidad de este compuesto para inhibir específicamente a las metiltransferasas de histonas. Por el contrario, los niveles de esta trimetilación aumentaron notablemente tras el tratamiento con JMJD2i, dado que la inhibición de la actividad demetilasa está directamente relacionada con el mantenimiento de un estado hipermetilado de la cromatina.

A continuación, quisimos corroborar el efecto de estos inhibidores sobre el ciclo celular. Con este objetivo, sincronizamos las células U2OS en G2/M con nocodazol y las tratamos con ambos inhibidores, chaetocin y JMJD2i. Tras analizar los perfiles de ciclo obtenidos, vimos que los dos compuestos impedían la progresión del ciclo tras 24 horas de tratamiento: el primero de ellos, chaetocin, en las fases G2/M, y el segundo, JMJD2i, en G0/G1. Estos resultados concuerdan con el hecho de que el inhibidor chaetocin induce la condensación de la cromatina (250). En condiciones normales, dicha condensación se revierte tras la mitosis (251), pero la presencia de este inhibidor interfiere en este proceso. Además, siguiendo con este argumento, podría explicarse el efecto de JMJD2i sobre el bloqueo durante las fases G0/G1 del ciclo celular. En este caso, el inhibidor favorece la descondensación de la cromatina asociada al final de la mitosis, pero impide que ésta se compacte de nuevo en el siguiente ciclo de división. 
Estos datos apoyarían el uso de ambos inhibidores en el tratamiento contra el cáncer, ya que los dos promueven la parada del ciclo en distintas fases, una de las principales estrategias utilizadas en clínica para combatir la progresión tumoral (252). Además, podría decirse que el inhibidor chaetocin tiene un efecto antitumoral adicional en este contexto, dado que la condensación irreversible de la cromatina que provoca es una característica típica de las células apoptóticas y senescentes (253). Sin embargo, nuestros estudios no muestran cambios en la viabilidad celular asociada al tratamiento con estos inhibidores, por lo que sería necesario realizar nuevos experimentos a distintos tiempos y con distintas concentraciones para determinar si son capaces de inducir muerte celular en este modelo experimental.

\section{Chaetocin}

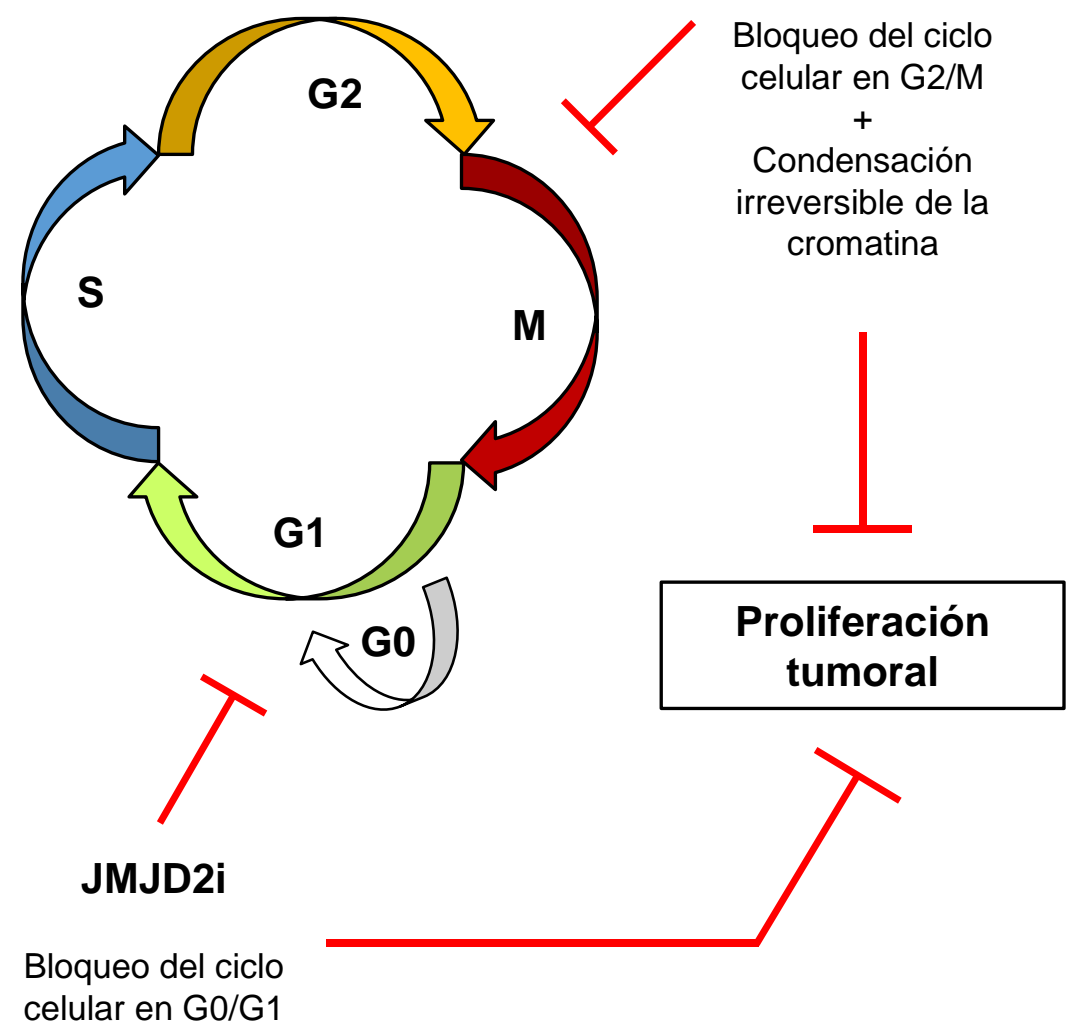

Figura 51: Esquema representativo del efecto de los inhibidores chaetocin y JMJD2i sobre el ciclo celular. 


\subsection{Implicación del inhibidor chaetocin en la respuesta al daño en el ADN}

La capacidad de generar estrés oxidativo es una de las características que convierte al inhibidor chaetocin en un posible agente quimioterapéutico (230). Esto se debe, principalmente, a que este compuesto compite con la tiorredoxina para unirse a la tiorredoxina reductasa e inhibirla, lo que se traduce en un aumento de la producción de especies reactivas de oxígeno (ROS) y de la oxidación de proteínas celulares (254). Dependiendo de la concentración celular, estas ROS pueden actuar como reguladores de rutas de señalización implicadas en supervivencia o proliferación (255) o inducir daño en el ADN y/o apoptosis $(256,257)$.

Con la intención de esclarecer el papel que juega el inhibidor chaetocin en la respuesta al daño génico, analizamos la inducción de roturas de doble cadena mediada por este compuesto en células U2OS crecidas en ausencia de suero $(0,5 \%$ FBS). Utilizando como marcador de estas DSBs a la histona H2AX fosforilada $(\mathrm{yH} 2 \mathrm{AX})$, observamos un aumento significativo del número de focos de $\mathrm{yH} 2 \mathrm{AX}$ asociado al inhibidor chaetocin. Sin embargo, la cantidad de focos formados como consecuencia del tratamiento con este inhibidor no era comparable a la de otras fuentes exógenas de estrés oxidativo como la radiación ionizante. Esto nos hizo pensar que la combinación de chaetocin con la radiación podría tener un efecto sinérgico y permitiría reducir las dosis de radiación, pero los resultados obtenidos demostraron que los focos de $\mathrm{yH} 2 \mathrm{AX}$ generados en respuesta al uso combinado de dosis más bajas de ambas fuentes de ROS era considerablemente menor que en el caso de la radiación más alta. Esto podría significar que la cantidad de especies reactivas de oxígeno asociadas al tratamiento con el inhibidor chaetocin son despreciables con respecto a las de la IR, por lo que no es posible detectar ningún efecto sinérgico entre este inhibidor y la radiación ionizante.

Dado que el modelo elegido para estudiar la respuesta al daño en el ADN fueron células U2OS sin suero (0,5\% FBS), que proliferan de manera significativamente menor que las que crecen en medio completo (10\% FBS), necesitábamos un segundo marcador asociado a la reparación de DSBs a través de un mecanismo que se pueda activar en cualquier fase del ciclo celular, como la unión de extremos no homólogos (NHEJ). Al igual que en el caso de la combinación de olaparib e IR, escogimos a la proteína 53BP1.

Aunque el propio inhibidor chaetocin induce daño en el ADN debido a la generación de estrés oxidativo, decidimos utilizar como referencia una fuente de DSBs más 
potente, la radiación ionizante. Tras generar daño génico con distintas dosis de IR en presencia o ausencia de chaetocin, observamos que este compuesto inhibía específicamente la formación de focos de 53BP1, sin que los de $\mathrm{yH} 2 \mathrm{AX}$ se viesen afectados. Además, el hecho de que los niveles proteicos no se alterasen nos hizo pensar que el efecto de este inhibidor estaba íntimamente relacionado con el reclutamiento de 53BP1 a las regiones del ADN dañadas y, posiblemente, a su unión a la cromatina. Por tanto, todos estos resultados indicaban que el inhibidor chaetocin alteraba algún parámetro de la respuesta a las DSBs localizado entre la detección del daño mediada por $\mathrm{YH} 2 \mathrm{AX}$ y la activación del mecanismo de reparación asociado a 53BP1.

Para validar este efecto, analizamos la formación de focos de $\mathrm{YH} 2 \mathrm{AX}$ y $53 \mathrm{BP} 1$ en respuesta al tratamiento con olaparib. Como ocurría tras la inducción de DSBs con radiación, el inhibidor chaetocin interfiere en la formación de focos de 53BP1 asociada a la exposición a este agente quimioterapéutico, poniendo de manifiesto que el efecto de este inhibidor de metiltransferasas sobre el reclutamiento y acumulación de 53BP1 durante el proceso de reparación del $A D N$ es independiente de la fuente de daño empleada.

Otra de las posibilidades que podría explicar el efecto del inhibidor chaetocin sobre la formación de focos de 53BP1 era que retrasase la acumulación de esta proteína en las DSBs. Por este motivo, realizamos una curva de tiempo post-irradiación en presencia o ausencia de dicho inhibidor. Los resultados obtenidos nos indicaron, por una parte, que el inhibidor chaetocin impedía la formación de focos de 53BP1 incluso 12 horas después de irradiar las células y, por otra, que el número y el tamaño de los focos de $\mathrm{yH} 2 \mathrm{AX}$ era mayor tras el tratamiento con este inhibidor sólo o en combinación con IR. Además, observamos un aumento de la fluorescencia asociada a 53BP1 en respuesta a chaetocin que nos estaría indicando que las células responden al daño e intentan reclutar a esta proteína a las DSBs, pero que no es capaz de formar los típicos focos de reparación. Probablemente, todos estos fenómenos están relacionados, ya que la no reparación de las roturas de doble cadena debido a los defectos en el reclutamiento de 53BP1 asociados al inhibidor chaetocin impide el desemsamblaje de los focos de reparación de $\mathrm{yH} 2 \mathrm{AX}$ que, en consecuencia, se acumulan y se vuelven más grandes.

Junto con la producción de ROS, la inhibición de las metiltransferasas de histonas es otra de las funciones mediada por chaetocin (227) y podría estar implicada en la respuesta al daño en el ADN. Por este motivo, evaluamos la formación de focos de reparación de $\mathrm{YH} 2 \mathrm{AX}$ y 53BP1 en presencia de JMJD2i, que tiene un efecto opuesto 
al del inhibidor chaetocin en lo que a la metilación de histonas se refiere. Como era de esperar, este inhibidor de demetilasas no alteraba ni la formación de focos de $\mathrm{yH} 2 \mathrm{AX}$ ni el reclutamiento de 53BP1 tras la inducción de daño génico con olaparib o IR. Estos datos nos llevaron a hipotetizar que el efecto sobre la acumulación de 53BP1 en los puntos donde se ha producido la rotura en el ADN asociado al inhibidor chaetocin podría deberse a la alteración del patrón de metilación de la cromatina, clave en la reparación de DSBs por unión de extremos no homólogos (96-98).

Antes de analizar las posibles metilaciones de histonas afectadas por el tratamiento con chaetocin, nos preguntamos si este inhibidor alteraba la formación de focos de otras proteínas implicadas en la reparación del ADN y que se reclutan a las DSBs antes que 53BP1, como es el caso de NBS1 y MDC1. Usando la radiación ionizante como fuente de daño, observamos que la presencia de chaetocin no interfería en la formación de los focos de reparación de estas proteínas.

También pensamos que este inhibidor de metiltransferasas podía estar modificando la relajación local de la cromatina, dado que el reclutamiento de acetiltransferasas como Tip60 depende de metilaciones concretas en las colas de las histonas $(72,73)$. Para corroborar esta hipótesis, inhibimos específicamente Tip60 con MG149 y analizamos posteriormente los niveles de la H4K16 (H4K16ac). Los resultados obtenidos mostraron cómo la disminución de acetilación de la H4K16 no afectaba a la formación de los focos de 53BP1. Esto quiere decir que las metilaciones necesarias para el reclutamiento de Tip60 no están asociadas al efecto del inhibidor chaetocin, ya que, en caso contrario, la inhibición de la actividad de Tip60 mediada por MG149 debería mimetizar las consecuencias del tratamiento con chaetocin.

El hecho de que la relajación de la cromatina y la fosforilación y/o reclutamiento de proteínas como la histona H2AX, NBS1 o MDC1 no se vean alteradas en respuesta a chaetocin y/o radiación ionizante nos llevó a pensar que las modificaciones covalentes de histonas que posiblemente se afecten por el tratamiento con este inhibidor interfieran en el reclutamiento de 53BP1 en sí mismo y su unión a la cromatina. Una de las modificaciones covalentes que media la interacción entre 53BP1 y la cromatina es la dimetilación de la lisina 20 de la histona H4 (H4K20me2). 53BP1 se une específicamente a este residuo dimetilado a través de sus dominios Tudor, lo que promueve la reparación por NHEJ $(97,98)$. Dado que se había descrito anteriormente que el inhibidor chaetocin interfería en la metilación de otros residuos en las histonas (227), pensamos que esta dimetilación de la histona $\mathrm{H} 4$ era uno de los candidatos para explicar el efecto de este compuesto sobre la acumulación de 53BP1 en las regiones dañadas de la cromatina. El análisis de los niveles de la H4K20me2 en 
respuesta a IR y al tratamiento con chaetocin mostraba que este inhibidor de metiltransferasas reducía notablemente esta dimetilación tras la inducción de daño génico con IR, mientras que no se observaban diferencias significativas entre el control y las células tratadas exclusivamente con chaetocin. Sin embargo, al evaluar mediante western blot el efecto de este inhibidor antes y después de irradiar las células, vimos que los niveles de la H4K20me2 disminuían considerablemente sin tener en cuenta la IR. Ambos resultados demuestran que la pérdida de esta metilación en respuesta al daño génico podría estar asociada a los defectos en el reclutamiento de 53BP1 debidos al tratamiento con chaetocin. Ahora bien, las diferencias encontradas entre las dos técnicas utilizadas, que sólo afectan a las células tratadas únicamente con chaetocin, pueden deberse a la capacidad diferencial del anticuerpo utilizado para reconocer este residuo dimetilado en condiciones nativas (fluorescencia) o desnaturalizadas (western blot).

La metilación en la lisina 20 de la histona H4 no sólo es importante para la reparación del ADN, sino que también se asocia a otros procesos celulares relacionados con el mantenimiento de la integridad genómica como la replicación del ADN o la compactación de la cromatina (258). Las metiltransferasas que median preferentemente la mono- y dimetilación de este residuo de la histona H4 son SET8 y SUV420H1, respectivamente, aunque en el contexto de daño génico, esta dimetilación depende de MMSET (97). Por tanto, a la vista del efecto del inhibidor chaetocin sobre la H4K20me2, sería interesante estudiar la relación funcional y/o la interacción de este compuesto con estas metiltransferasas.

Por último, nos preguntamos si el inhibidor chaetocin alteraría, de manera indirecta, a otras modificaciones en las histonas. Concretamente, nos centramos en la acetilación de la H4K16, basándonos en estudios previos que demuestran que esta modificación impide la unión de 53BP1 a la H4K20me2 (104). En este caso, suponíamos que la acetilación de este residuo seguiría siendo muy alta en presencia del inhibidor de metiltransferasas. Para verificar nuestra hipótesis, analizamos los niveles de la H4K16ac mediante microscopía confocal y western blot tras la inducción de daño con IR y/o el tratamiento con chaetocin y, como esperábamos, la presencia de este inhibidor no alteraba la acumulación de la H4K16ac en respuesta a IR. En consecuencia, podemos decir que el inhibidor chaetocin reduce significativamente los niveles de H4K20me2 e, indirectamente, favorece la acetilación de la H4K16, impidiendo el reclutamiento de 53BP1 y su unión a la cromatina e interfiriendo así en la respuesta al daño en el ADN. 

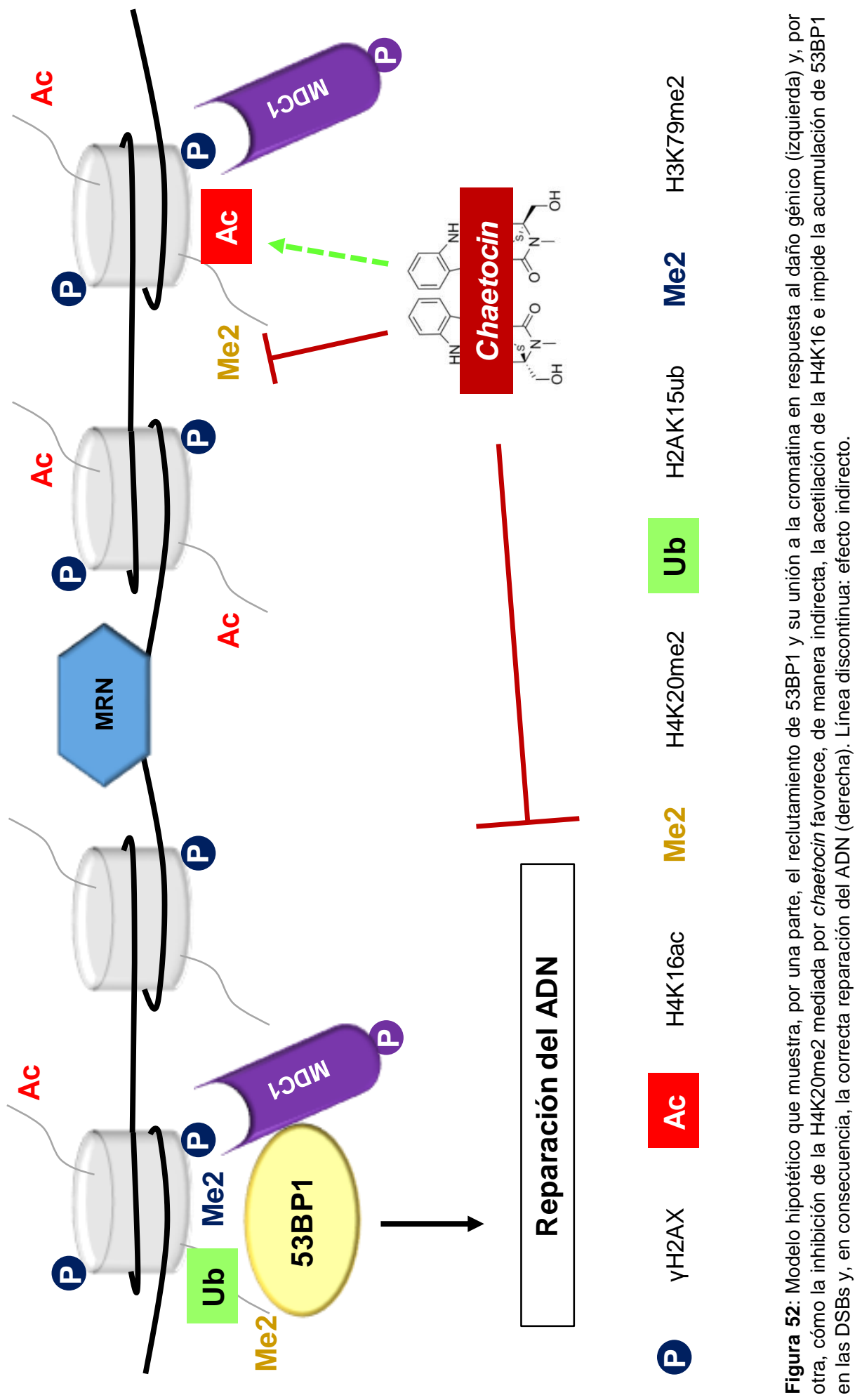
El descubrimiento de este nuevo mecanismo molecular por el cual el inhibidor chaetocin modula la respuesta al daño en el ADN ayudaría a explicar, junto con la generación de ROS, la inducción de apoptosis y la inhibición de la proliferación celular (229, 230, 259-266), el efecto antitumoral de este metabolito fúngico y aportaría nuevos argumentos para su utilización clínica como fármaco epigenético. 


\section{IMPLICACIÓN DE LA QUINASA HUMANA VRK1 EN LA REGULACIÓN DE LAS MODIFICACIONES COVALENTES DE LAS HISTONAS H3 Y H4}

Los extremos $\mathrm{N}$-terminales de las histonas que forman el nucleosoma se modifican covalentemente de manera diferencial en función del proceso celular en el que participen (22). El elevado número de modificaciones covalentes y, sobre todo, la relación o cross-talk que existe entre ellas, contribuyen enormemente a la regulación de la estructura de la cromatina (267).

El genoma de las células eucariotas, desde el punto de vista de la cromatina, puede dividirse en dos grandes regiones, que difieren significativamente en cuanto al tipo de modificaciones presentes en las histonas: eucromatina y heterocromatina. La eucromatina se caracteriza por tener una estructura más relajada, contener la mayoría de los genes que se transcriben y estar sujeta a cambios asociados al ciclo celular, mientras que la heterocromatina es mucho más compacta y suele ser refractaria a los cambios cíclicos relacionados con la división celular (267).

En esta tesis doctoral nos hemos centrado en el patrón de acetilación/metilación de residuos concretos de las histonas H3 y H4 en la línea celular A549 y hemos demostrado que la quinasa de la cromatina VRK1 actúa como un regulador indirecto de dichas modificaciones asociadas con la relajación o compactación de la cromatina.

\subsection{Cambios en la acetilación de la lisina $\mathbf{1 6}$ de la histona H4 asociados al silenciamiento de VRK1}

VRK1 es una quinasa de cromatina capaz de fosforilar tanto proteínas implicadas en la respuesta al daño como factores de transcripción e histonas, entre otras. Precisamente, las fosforilaciones en las distintas histonas del nucleosoma mediadas por esta quinasa la sitúan en el control de la proliferación celular (179), la condensación de la cromatina en las fases G2/M del ciclo celular (152), y las primeras etapas de la respuesta al daño génico (85). Además, se ha descrito el efecto del silenciamiento de esta quinasa en la regulación de distintos residuos acetilados de las histonas $\mathrm{H} 3$ y H4 (85). Todos estos datos indican que la quinasa VRK1 está presente en multitud de procesos celulares y participa en la regulación de la estructura de la cromatina de manera directa e indirecta, por lo que quisimos estudiar, en primer lugar, las variaciones en la acetilación de la H4K16 asociadas a la presencia o ausencia de VRK1 y cómo esta quinasa podría estar controlando dichas variaciones. 
La acetilación de la histona $\mathrm{H} 4$ en la lisina 16 juega un papel esencial durante la transcripción (42) y la reparación del ADN (69-71), procesos en los que es necesario que la cromatina se relaje. Además, es la única modificación covalente que impide la correcta formación de la fibra de $30 \mathrm{~nm}$, asociada a la compactación de la cromatina durante la división celular (225).

El balance entre las acetiltransferasas (HATs) y las deacetilasas (HDACs) de histonas determina el patrón de acetilación de la lisina 16 de la histona H4 en los distintos procesos celulares en los que participa. Tip60 y MOF son las principales enzimas que catalizan la acetilación de este residuo, mientras que SIRT1 es la deacetilasa que media la eliminación del grupo acetilo de la H4K16 y de otros residuos en la histona H3 (268).

Nuestros experimentos demuestran que el silenciamiento de VRK1 conlleva una reducción significativa de los niveles de acetilación de la H4K16. Estos resultados nos hicieron pensar que esta quinasa regula positivamente a las acetiltransferasas Tip60 y/o MOF, o interfiere negativamente en la actividad deacetilasa de SIRT1. Para comprobar estas hipótesis, utilizamos, en primer lugar, un pan-inhibidor de deacetilasas, SAHA, y uno más específico dirigido frente a las deacetilasas de las clases I y III, entinostat. Si VRK1 inhibiese a SIRT1 (clase III), como se podría deducir de nuestros experimientos, esperaríamos que tanto entinostat como SAHA mantuviesen elevados los niveles de acetilación de la H4K16 en presencia o ausencia de esta quinasa, y nuestros datos confirman esta premisa. Por tanto, no podemos descartar que esta quinasa de la cromatina regule negativamente la actividad deacetilasa de SIRT1.

A continuación, nos preguntamos cuál sería el efecto de la inhibición de HATs sobre la H4K16ac, lo que podría explicar también las consecuencias del silenciamiento de VRK1 sobre esta acetilación. En este caso, empleamos C646, un inhibidor que tiene a p300/CBP como diana, y MG149, que está dirigido específicamente frente a Tip60. Los resultados obtenidos demostraron que la inhibición de Tip60 mediada por MG149 mimetiza el efecto del silenciamiento de VRK1 sobre la acetilación de la H4K16, mientras que el inhibidor C646 no altera el patrón de esta acetilación en presencia de dicha quinasa. Con todo esto, podemos decir que Tip60 es una diana potencial de VRK1, lo que explicaría no sólo el efecto del silenciamiento de esta quinasa sobre la H4K16ac en condiciones basales, sino también en respuesta al daño génico.

A pesar de que los datos obtenidos apuntan a la regulación de Tip60, no podemos descartar que VRK1 pueda inhibir también a MOF. Mediante HTS (high throughput 
screening) se ha encontrado un nuevo inhibidor dirigido particularmente frente a esta acetiltransferasa, denominado DC_M01_7 (269), que podría usarse para confirmar si MOF también es una posible diana de VRK1.

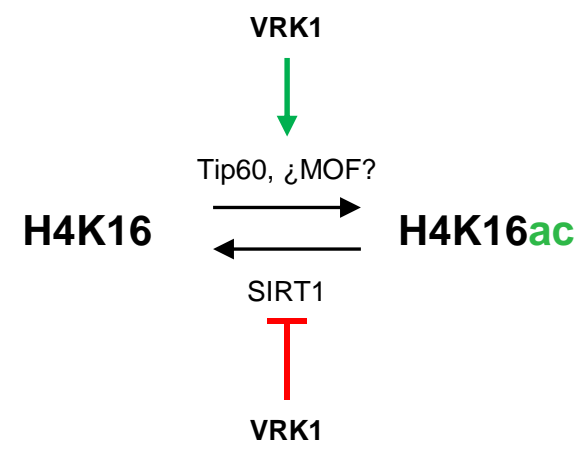

Figura 53: Regulación de la acetilación de la H4K16 mediada por VRK1. MOF aparece entre signos de interrogación al no haber utilizado un inhibidor específico de esta HAT con el que comparar el efecto del silenciamiento de VRK1.

\subsection{Regulación de la trimetilación de la lisina 4 de la histona H3 mediada por la quinasa VRK1}

El siguiente residuo que quisimos caracterizar, la trimetilación de la H3K4, también está asociado a la relajación de la cromatina, principalmente en el inicio de la transcripción $(34,40)$. Los modificadores de cromatina más importantes que median esta trimetilación pertenecen a la familia MLL y a los complejos SETD1 y 2 (40, 270), mientras que son varias las demetilasas (KDMs) que se encargan de la eliminación del grupo metilo de este residuo. Una de ellas es KDM2B, capaz de demetilar esta lisina de la histona $\mathrm{H} 3$ junto con otras dos marcas epigenéticas (H3K36me1/2 y H3K79me2/3) en los promotores transcripcionalmente activos (271). Las demás pertenecen a la subfamila KDM5 y se caracterizan por la presencia de un dominio catalítico JmjC y por demetilar también a la H3K4me2 (272).

Al igual que con la H4K16ac, estudiamos los cambios en los niveles de trimetilación de la H3K4 en presencia o ausencia de VRK1 y vimos que estos niveles disminuían tras silenciar VRK1, un efecto descrito anteriormente en el contexto del promotor de la ciclina D1 (179). Esto quiere decir que, hipotéticamente, VRK1 podría estar activando a las metiltransferasas (KMTs) que median esta trimetilación o inhibiendo a las demetilasas correspondientes, lo que impediría que los niveles basales de metilación disminuyesen. Para determinar qué enzimas están implicadas en la regulación de la H3K4me3 asociada a VRK1, utilizamos la misma estrategia que para la H4K16ac, el 
tratamiento con inhibidores específicos, en este caso, de las KMTs y las KDMs (chaetocin y JMJD2i, respectivamente). Tras analizar los resultados, observamos que los niveles de la $\mathrm{H} 3 \mathrm{~K} 4 \mathrm{me} 3$ eran significativamente mayores que los basales tras el tratamiento con JMJD2i tanto en presencia como en ausencia de VRK1. Ahora bien, el inhibidor chaetocin sí que mostró un efecto similar al silenciamiento de VRK1 sobre la trimetilación de la H3K4. Por tanto, la explicación más plausible de estos resultados es que VRK1 favorece el correcto funcionamiento de las metiltransferasas de histonas asociadas a la $\mathrm{H} 3 \mathrm{~K} 4 \mathrm{me} 3 \mathrm{y} / \mathrm{o}$ inhibe la actividad demetilasa de KDM2B y/o de la subfamilia KDM5. Sin embargo, es necesario tener en cuenta otros factores que podrían modificar esta teoría.

El primero de ellos es el hecho de que experimentos con ratones en los que se han delecionado o truncado algunas de las metiltransferasas de la familia MLL muestran fenotipos claramente diferenciales, lo que sugiere que estas enzimas no son redundantes y juegan distintas funciones en la célula (270). En este trabajo observamos cambios globales en el patrón de metilación de la H3K4, por lo que sería conveniente analizar el efecto del silenciamiento de VRK1 en un contexto celular concreto y evaluar la posible regulación que esta quinasa ejerce sobre cada uno de los miembros de esta familia de KMTs.

Otro de los factores que alteraría la interpretación de nuestros resultados es que la lisina 4 de la histona H3 también puede acetilarse (H3K4ac). Esta acetilación está presente, al igual que la trimetilación, en las regiones promotoras de los genes que se van a transcribir $(273,274)$. Dado que ambas modificaciones son mutuamente excluyentes, el balance entre acetilación y metilación debe estar estrictamente regulado y cabe la posibilidad de que VRK1 no sólo active a las KMTs o inhiba a las KDMs, sino que tenga un efecto indirecto asociado a la activación de las HDACs o la inhibición de las HATs que catalizan la acetilación de la H3K4 (Figura 54). Se sabe que en levaduras, la acetilación de esta lisina depende de Gcn5 y Rtt109 y la deacetilación, de Hst1 y Sir2 (274), mientras que en humanos se ha descrito que la expresión de Tip60 se asocia con esta acetilación y que SIRT1 deacetila este residuo en líneas de cáncer de mama $(275,276)$. Por consiguiente, sería interesante evaluar también el papel de VRK1 en la regulación de estos modificadores de cromatina relacionados con la acetilación de la H3K4. 


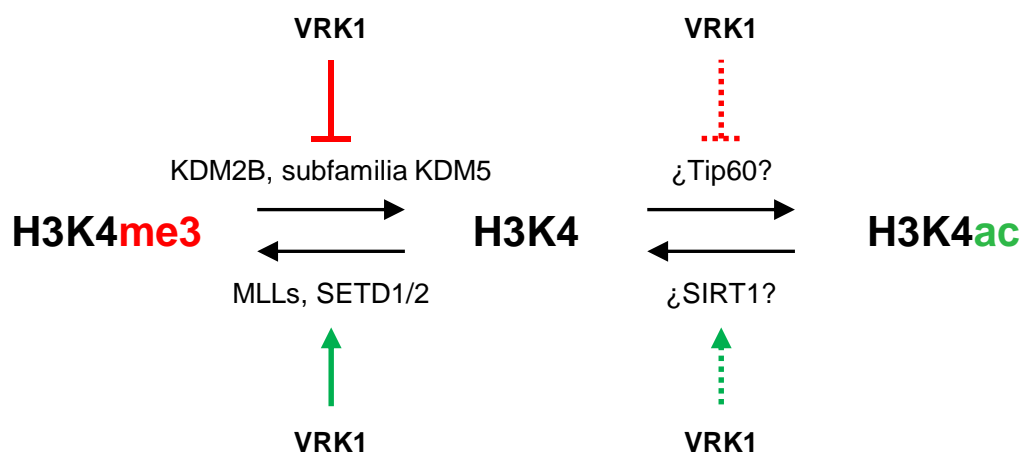

Figura 54: Modelo hipotético de la regulación de las modificaciones covalentes en la lisina 4 de la histona $\mathrm{H} 3$ asociada a la quinasa VRK1. En línea discontinua se muestra el posible efecto de VRK1 sobre los modificadores de HDACs y HATs que explicarían los datos obtenido tras el silenciamiento de esta quinasa sobre la $\mathrm{H} 3 \mathrm{~K} 4 \mathrm{me} 3$, pero que no se han analizado experimentalmente. Los mediadores más probables de la acetilación y deacetilación de la H3K4 aparecen entre signos de interrogación.

\subsection{Cambios en la acetilación y trimetilación de la lisina 9 de la histona H3 mediados por VRK1}

Tras evaluar las consecuencias del silenciamiento de $V R K 1$ sobre la acetilación de la H4K16 y trimetilación de la H3K4, nos planteamos el efecto que tendría esta quinasa en la regulación de las modificaciones covalentes de la lisina 9 de la histona $\mathrm{H} 3$, un residuo que, dependiendo de si está acetilado o trimetilado (H3K9ac o H3K9me3), promueve la relajación o compactación de la cromatina, respectivamente (40).

Nuestros resultados sugieren que la quinasa VRK1 regula positivamente la acetilación de la H3K9 en detrimento de la metilación, en base a los datos obtenidos en presencia o ausencia de esta quinasa. Quisimos profundizar en la regulación de modificadores de cromatina implicados en la acetilación o metilación de la H3K9 y, con ese objetivo, evaluamos el efecto de los inhibidores de HATs (C646 y MG149) y HDACs (entinostat y SAHA) sobre la H3K9ac y de los de KMTs (chaetocin) y KDMs (JMJD2i) sobre la H3K9me3.

Una de las deacetilasas que regula la transición entre acetilación y metilación de este residuo durante la reparación del ADN y la transcripción es HDAC3 (clase I) (277). E efecto esperable de entinostat y SAHA, en caso de que la H3K9ac estuviese regulada negativamente por VRK1, como cabría suponer en base a las consecuencias del silenciamiento de $V R K 1$, es que los niveles de esta acetilación siguiesen siendo tanto o más altos que en condiciones basales. El análisis de nuestros datos confirmó esta 
teoría, lo que nos lleva a pensar que VRK1 podría estar actuando como un inhibidor más de HDACs.

A continuación, estudiamos los cambios en los niveles de la H3K9ac asociados al tratamiento con C646 y MG149 (inhibidores de p300/CBP y Tip60, respectivamente) y al silenciamiento de VRK1. Nos llamó la atención el hecho de que el inhibidor C646 y, en menor medida, el MG149, redujesen los niveles de la H3K9ac en presencia de VRK1, ya que, desde un punto de vista teórico, ninguno de estos inhibidores debería regular negativamente a PCAF o GCN5, las enzimas encargadas de catalizar esta acetilación en distintos contextos celulares $(41,69)$. Este resultado podría explicarse suponiendo que dichos inhibidores no son del todo específicos o que la concentración utilizada es demasiado alta, lo que conllevaría, en ambos casos, una unión inespecífica con otras HATs e interferiría en su actividad acetiltansferasa. Ahora bien, el hecho de que estos inhibidores de acetiltransferasas reduzcan la acetilación de la H3K9, aunque no de manera tan significativa como el silenciamiento de VRK1, nos plantea la posibilidad de que esta quinasa regule positivamente a alguna de las HATs implicadas en dicha acetilación, GCN5 y/o PCAF, pero serían necesarios experimentos adicionales para confirmarlo.

Una vez analizada la posible regulación de HATs y HDACs mediada por VRK1 sobre la H3K9ac, decidimos evaluar las variaciones en la trimetilación de este mismo residuo asociadas al tratamiento con inhibidores de KMTs (chaetocin) y KDMs (JMJD2i) en presencia o ausencia de VRK1. En las células eucariotas podemos encontrar gran variedad de enzimas que catalizan la trimetilación de este residuo, pertenecientes a la subfamilia SUV39 (SUV39H1/2 y SETDB1/2, mayoritariamente) (278), mientras que la demetilación de la H3K9me3 suele estar mediada por los miembros de la familia de demetilasas JMJD2 (A-D) (279).

El inhibidor chaetocin mantiene los niveles basales de H3K9me3 en presencia de VRK1, mientras que la ausencia de VRK1 y el tratamiento con este inhibidor de KMTs se tradujo en un aumento de dicha trimetilación, sin llegar a alcanzarse los niveles asociados a silenciamiento de esta quinasa en ausencia de chaetocin. Esto indica que VRK1 podría estar inhibiendo a las metiltransferasas de la subfamilia SUV39 y se deduce del hecho de que, al silenciar dicha quinasa, estamos "eliminando" un regulador negativo de estas KMTs y la presencia del inhibidor chaetocin sólo compensa, en parte, la pérdida de VRK1 e impide que este residuo se trimetile.

Por otra parte, el silenciamiento de VRK1 aumenta significativamente los niveles de la H3K9me3 y el inhibidor JMJD2i tiene el mismo efecto tanto en presencia como en 
ausencia de esta quinasa. La explicación a estos resultados sería que VRK1 activa a las demetilasas de la familia JMJD2, ya que la inhibición mediada por JMJD2i favorece el incremento de los niveles de la H3K9me3 aunque esta quinasa esté presente, lo que la coloca como un potencial regulador positivo de esta familia de demetilasas.

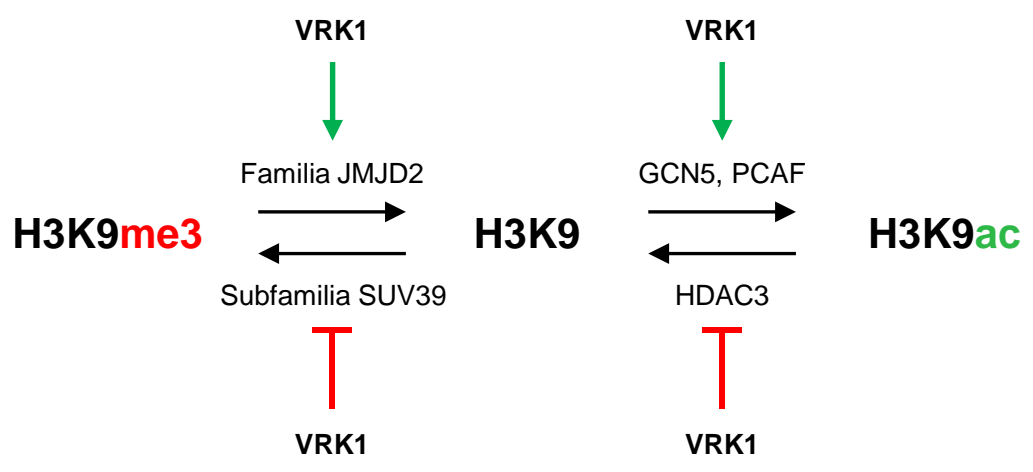

Figura 55: Cambios en la acetilación y la trimetilación de la H3K9 mediados por VRK1, indicando las enzimas que esta quinasa de la cromatina podría estar regulando.

Por último, sería interesante analizar el posible efecto indirecto de los inhibidores de acetilasas/deacetilasas sobre la H3K9me3 y de los de metiltransferasas/demetilasas sobre la H3K9ac. En estos supuestos, la inhibición de las HDACs favorecería la acumulación de la acetilación de la H3K9 (Figura 56.A), con lo que cabría esperar que la metilación disminuyese, mientras que los inhibidores de HATs deberían promover dicha metilación (Figura 56.C). Del mismo modo, el inhibidor de KMTs (chaetocin), al impedir la metilación de la H3K9, contribuiría indirectamente al aumento de la acetilación (Figura 56.B), y el de demetilasas, que mantendría los niveles de metilación elevados, conllevaría la disminución de la H3K9ac (Figura 56.D). 
A

H3K9me3

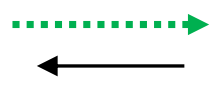

H3K9
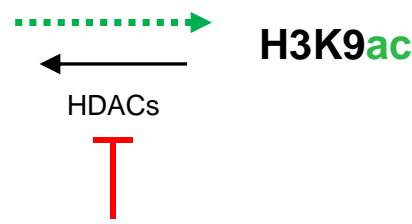

Entinostat/SAHA

B

H3K9me3

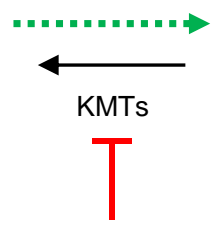

H3K9

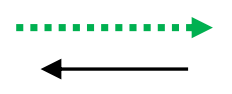

H3K9ac

Chaetocin

C

H3K9me3

JMJD2i

D
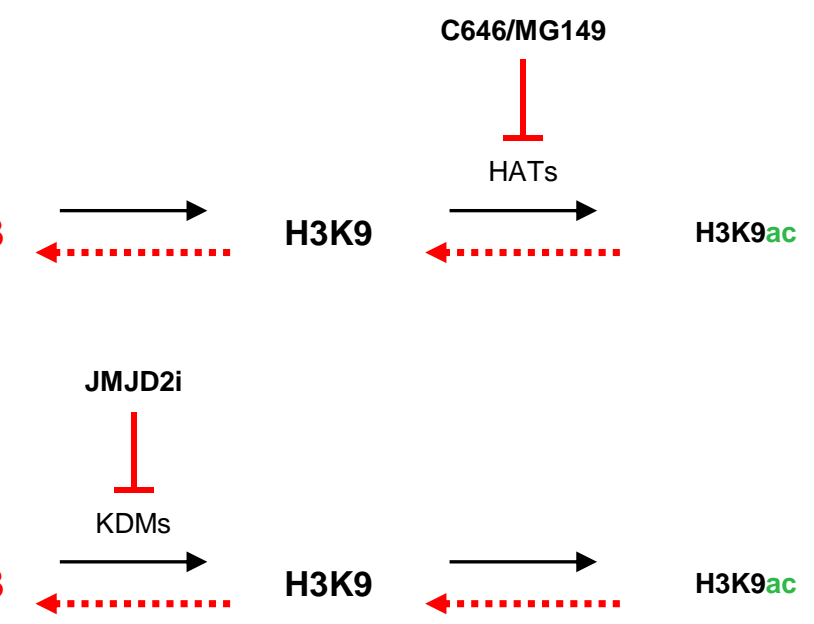

Figura 56: Efecto indirecto de los inhibidores de acetilasas/deacetilasas sobre la H3K9me3 y de los de metiltransferasas/demetilasas sobre la H3K9ac (representado con línea discontinua). El tamaño de cada modificación (acetilación o metilación) corresponde al aumento o disminución esperado de sus niveles en función del inhibidor utilizado.

\subsection{Modificación del patrón de acetilación/metilación de las histonas $\mathrm{H} 3$ y $\mathrm{H} 4$ como consecuencia del silenciamiento de VRK1}

Las modificaciones covalentes estudiadas en esta tesis doctoral están íntimamente relacionadas desde el punto de vista funcional, ya que las acetilaciones de la H3K9 y 
H4K16, y la trimetilación de la H3K4 son marcadores asociados a una estructura abierta de la cromatina y transcripcionalmente activa, mientras que la trimetilación de la $\mathrm{H} 3 \mathrm{~K} 9$ aparece mayoritariamente en regiones compactadas que no se transcriben $(22,34,40,42)$.

Si analizamos en conjunto los resultados obtenidos tras el silenciamiento de VRK1, observamos una reducción considerable de las marcas epigenéticas propias de la cromatina relajada (H3K9ac, H4K16ac y H3K4me3) y el aumento de las que están vinculadas a una estructura más compactada (H3K9me3) (Figura 57). Por tanto, podemos concluir que, en condiciones basales, la quinasa VRK1 favorece la relajación de la cromatina.
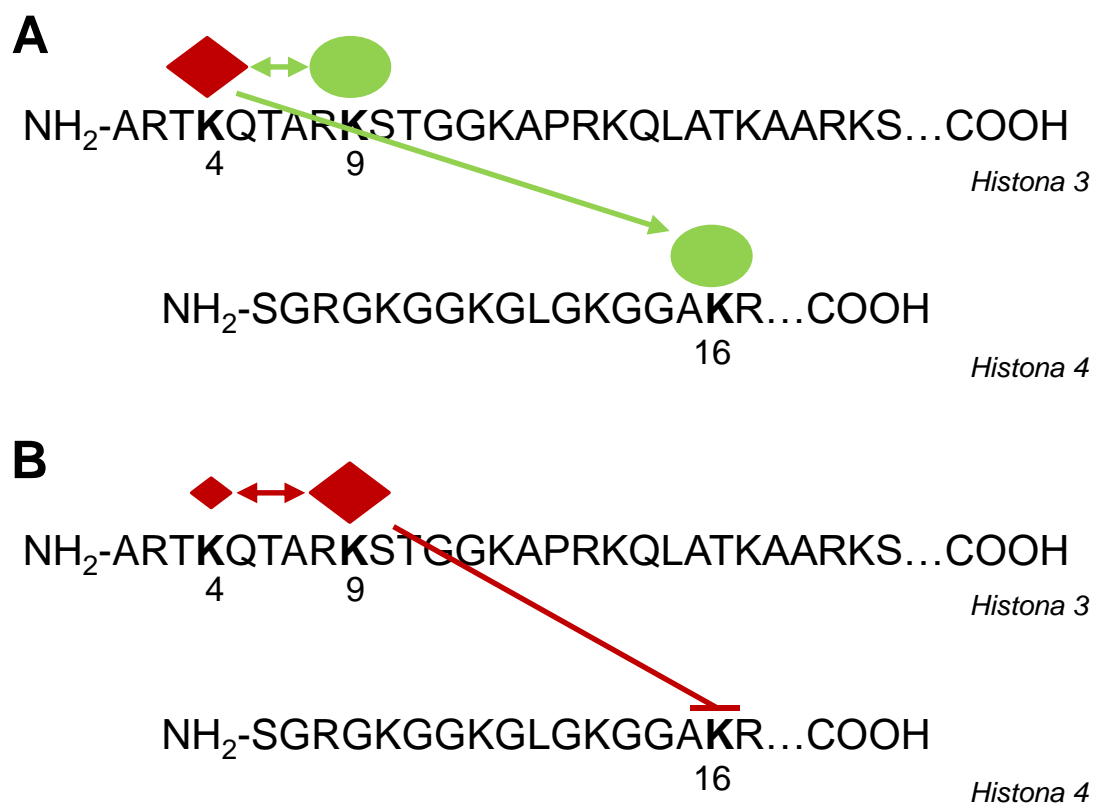

\section{Acetilación $>$ Trimetilación}

Figura 57: Cambios globales en el patrón de acetilación/metilación asociados al silenciamiento de VRK1. A. La presencia de VRK1 promueve la aparición de marcas epigenéticas asociadas a relajación de la cromatina. La flecha en las dos direcciones indica que ambas modificaciones se regulan positivamente entre ellas. B. El silenciamiento de VRK1 favorece la compactación de la cromatina. La flecha en las dos direcciones, en este caso, determina que estas dos modificaciones covalentes son mutuamente excluyentes.

Ahora bien, al evaluar de forma global estos cambios en la estructura cromatínica, no podemos determinar qué zonas se acetilan o metilan de forma diferencial o cómo se regulan los distintos procesos celulares en función del estatus de VRK1. Para 
responder a estas cuestiones, sería necesario realizar estudios de ChIP-seq en los que se analizasen, de manera pormenorizada, las variaciones en estas modificaciones covalentes de las histonas en regiones concretas del ADN y en situaciones fisiológicas o patológicas diversas, lo que permitiría situar a VRK1 como un modulador de la cromatina en contextos celulares específicos. Además, convendría llevar a cabo también un análisis por espectrometría de masas que confirmara de manera más precisa el efecto del silenciamiento de esta quinasa sobre estas modificaciones covalentes de la cromatina. 



\section{Conclusiones}

1. La combinación de olaparib $(5 \mu \mathrm{M})$ y radiación ionizante (1 Gy) genera la misma cantidad de daño en el ADN, evaluada a través de la formación de focos de $\mathrm{YH} 2 \mathrm{AX}$ y 53BP1, que las dosis más altas de cada uno de estos tratamientos por separado.

2. El silenciamiento de la quinasa humana VRK1 interfiere en la acetilación de la lisina 16 de la histona $\mathrm{H} 4$ y en la formación de focos de reparación de YH2AX, NBS1 y 53BP1 tras la inducción de daño génico con olaparib y/o radiación ionizante.

3. El efecto del silenciamiento de VRK1 sobre la respuesta al daño génico ocasionado por la combinación de olaparib y radiación ionizante es independiente de p53 y ATM.

4. El inhibidor de metiltransferasas chaetocin bloquea la progresión del ciclo celular en las fases $\mathrm{G} 2 / \mathrm{M}$.

5. El tratamiento con chaetocin impide la correcta formación de focos de 53BP1 al inhibir la dimetilación de la lisina 20 de la histona $\mathrm{H} 4$ y favorecer, indirectamente, la acetilación de la lisina 16 de esta misma histona en respuesta al daño en el ADN.

6. VRK1 altera el patrón de acetilación y metilación de las histonas H3 y H4, dado que el silenciamiento de esta quinasa de la cromatina se asocia, por una parte, con un aumento significativo de la trimetilación de la lisina 9 de la histona $\mathrm{H} 3 \mathrm{y}$, por otra, con la disminución igualmente significativa de la acetilación de la lisina 16 de la histona $\mathrm{H} 4$ y de la trimetilación y acetilación de las lisinas 4 y 9 de la histona $\mathrm{H} 3$, respectivamente. 



\section{Bíbliografía}



1. Olins AL, Olins DE. Spheroid chromatin units ( $v$ bodies). Science. 1974;183(4122):330-2.

2. Oudet P, Gross-Bellard M, Chambon P. Electron microscopic and biochemical evidence that chromatin structure is a repeating unit. Cell. 1975;4(4):281-300.

3. Cutter AR, Hayes JJ. A brief review of nucleosome structure. FEBS Lett. 2015;589(20 Pt A):2914-22.

4. Koyama M, Kurumizaka H. Structural diversity of the nucleosome. J Biochem. 2018;163(2):85-95.

5. Marzluff WF, Wagner EJ, Duronio RJ. Metabolism and regulation of canonical histone mRNAs: life without a poly(A) tail. Nat Rev Genet. 2008;9(11):843-54.

6. Talbert PB, Ahmad K, Almouzni G, Ausio J, Berger F, Bhalla PL, et al. A unified phylogeny-based nomenclature for histone variants. Epigenetics Chromatin. 2012;5:7.

7. Zhou J, Fan JY, Rangasamy D, Tremethick DJ. The nucleosome surface regulates chromatin compaction and couples it with transcriptional repression. Nat Struct Mol Biol. 2007;14(11):1070-6.

8. Bonisch C, Schneider K, Punzeler S, Wiedemann SM, Bielmeier C, Bocola M, et al. H2A.Z.2.2 is an alternatively spliced histone H2A.Z variant that causes severe nucleosome destabilization. Nucleic Acids Res. 2012;40(13):5951-64.

9. Jin C, Zang C, Wei G, Cui K, Peng W, Zhao K, et al. H3.3/H2A.Z double variant-containing nucleosomes mark 'nucleosome-free regions' of active promoters and other regulatory regions. Nat Genet. 2009;41(8):941-5.

10. Singh N, Basnet H, Wiltshire TD, Mohammad DH, Thompson JR, Heroux A, et al. Dual recognition of phosphoserine and phosphotyrosine in histone variant H2A.X by DNA damage response protein MCPH1. Proc Natl Acad Sci U S A. 2012;109(36):14381-6.

11. Draker R, Ng MK, Sarcinella E, Ignatchenko V, Kislinger T, Cheung P. A combination of H2A.Z and $\mathrm{H} 4$ acetylation recruits Brd2 to chromatin during transcriptional activation. PLoS Genet. 2012;8(11):e1003047.

12. Buschbeck M, Hake SB. Variants of core histones and their roles in cell fate decisions, development and cancer. Nat Rev Mol Cell Biol. 2017;18(5):299314.

13. Berger SL, Kouzarides T, Shiekhattar R, Shilatifard A. An operational definition of epigenetics. Genes Dev. 2009;23(7):781-3.

14. Kulis M, Esteller M. DNA methylation and cancer. Adv Genet. 2010;70:27-56.

15. Akey CW, Luger K. Histone chaperones and nucleosome assembly. Curr Opin Struct Biol. 2003;13(1):6-14.

16. Avvakumov N, Nourani A, Cote J. Histone chaperones: modulators of chromatin marks. Mol Cell. 2011;41(5):502-14.

17. Hamiche A, Shuaib M. Chaperoning the histone $\mathrm{H} 3$ family. Biochim Biophys Acta. 2013;1819(3-4):230-7.

18. Langst G, Manelyte L. Chromatin Remodelers: From Function to Dysfunction. Genes (Basel). 2015;6(2):299-324.

19. Tyagi M, Imam N, Verma K, Patel AK. Chromatin remodelers: We are the drivers!! Nucleus. 2016;7(4):388-404.

20. Filippakopoulos $\mathrm{P}, \mathrm{Knapp} \mathrm{S}$. The bromodomain interaction module. FEBS Lett. 2012;586(17):2692-704.

21. Clapier CR, Cairns BR. The biology of chromatin remodeling complexes. Annu Rev Biochem. 2009;78:273-304.

22. Kouzarides T. Chromatin modifications and their function. Cell. 2007;128(4):693-705.

23. Sterner DE, Berger SL. Acetylation of histones and transcription-related factors. Microbiol Mol Biol Rev. 2000;64(2):435-59. 
24. DesJarlais R, Tummino PJ. Role of Histone-Modifying Enzymes and Their Complexes in Regulation of Chromatin Biology. Biochemistry. 2016;55(11):1584-99.

25. Zhang $\mathrm{Y}$, Reinberg D. Transcription regulation by histone methylation: interplay between different covalent modifications of the core histone tails. Genes Dev. 2001;15(18):2343-60.

26. Shilatifard A. Chromatin modifications by methylation and ubiquitination: implications in the regulation of gene expression. Annu Rev Biochem. 2006;75:243-69.

27. Ubersax JA, Ferrell JE, Jr. Mechanisms of specificity in protein phosphorylation. Nat Rev Mol Cell Biol. 2007;8(7):530-41.

28. Komander D. The emerging complexity of protein ubiquitination. Biochem Soc Trans. 2009;37(Pt 5):937-53.

29. Osley MA, Fleming AB, Kao CF. Histone ubiquitylation and the regulation of transcription. Results Probl Cell Differ. 2006;41:47-75.

30. Mailand N, Bekker-Jensen S, Faustrup H, Melander F, Bartek J, Lukas C, et al. RNF8 ubiquitylates histones at DNA double-strand breaks and promotes assembly of repair proteins. Cell. 2007;131(5):887-900.

31. Doil C, Mailand N, Bekker-Jensen S, Menard P, Larsen DH, Pepperkok R, et al. RNF168 binds and amplifies ubiquitin conjugates on damaged chromosomes to allow accumulation of repair proteins. Cell. 2009;136(3):43546.

32. Ginjala V, Nacerddine K, Kulkarni A, Oza J, Hill SJ, Yao M, et al. BMl1 is recruited to DNA breaks and contributes to DNA damage-induced H2A ubiquitination and repair. Mol Cell Biol. 2011;31(10):1972-82.

33. Huang H, Sabari BR, Garcia BA, Allis CD, Zhao Y. SnapShot: histone modifications. Cell. 2014;159(2):458- e1.

34. Ehrenhofer-Murray AE. Chromatin dynamics at DNA replication, transcription and repair. Eur J Biochem. 2004;271(12):2335-49.

35. Alabert $\mathrm{C}$, Groth $\mathrm{A}$. Chromatin replication and epigenome maintenance. Nat Rev Mol Cell Biol. 2012;13(3):153-67.

36. Alabert C, Jasencakova Z, Groth A. Chromatin Replication and Histone Dynamics. Adv Exp Med Biol. 2017;1042:311-33.

37. Bar-Ziv R, Voichek Y, Barkai N. Chromatin dynamics during DNA replication. Genome Res. 2016;26(9):1245-56.

38. Hammond CM, Stromme CB, Huang H, Patel DJ, Groth A. Histone chaperone networks shaping chromatin function. Nat Rev Mol Cell Biol. 2017;18(3):141-58.

39. Kurat CF, Yeeles JTP, Patel H, Early A, Diffley JFX. Chromatin Controls DNA Replication Origin Selection, Lagging-Strand Synthesis, and Replication Fork Rates. Mol Cell. 2017;65(1):117-30.

40. Gates LA, Foulds CE, O'Malley BW. Histone Marks in the 'Driver's Seat': Functional Roles in Steering the Transcription Cycle. Trends Biochem Sci. 2017;42(12):977-89.

41. Gates LA, Shi J, Rohira AD, Feng Q, Zhu B, Bedford MT, et al. Acetylation on histone H3 lysine 9 mediates a switch from transcription initiation to elongation. J Biol Chem. 2017;292(35):14456-72.

42. Zippo A, Serafini R, Rocchigiani M, Pennacchini S, Krepelova A, Oliviero S. Histone crosstalk between H3S10ph and H4K16ac generates a histone code that mediates transcription elongation. Cell. 2009;138(6):1122-36.

43. Smith E, Shilatifard $A$. The chromatin signaling pathway: diverse mechanisms of recruitment of histone-modifying enzymes and varied biological outcomes. Mol Cell. 2010;40(5):689-701.

44. Skourti-Stathaki K, Kamieniarz-Gdula K, Proudfoot NJ. R-loops induce repressive chromatin marks over mammalian gene terminators. Nature. 2014;516(7531):436-9. 
45. Lee JH, Kang $\mathrm{BH}$, Jang $\mathrm{H}$, Kim TW, Choi J, Kwak S, et al. AKT phosphorylates $\mathrm{H} 3$-threonine 45 to facilitate termination of gene transcription in response to DNA damage. Nucleic Acids Res. 2015;43(9):4505-16.

46. Suganuma T, Workman JL. Crosstalk among Histone Modifications. Cell. 2008;135(4):604-7.

47. Lee JS, Smith E, Shilatifard A. The language of histone crosstalk. Cell. 2010;142(5):682-5.

48. Yao T, Jing W, Hu Z, Tan M, Cao M, Wang Q, et al. Structural basis of the crosstalk between histone $\mathrm{H} 2 \mathrm{~B}$ monoubiquitination and $\mathrm{H} 3$ lysine 79 methylation on nucleosome. Cell Res. 2019;29(4):330-3.

49. Altaf M, Utley RT, Lacoste N, Tan S, Briggs SD, Cote J. Interplay of chromatin modifiers on a short basic patch of histone $\mathrm{H} 4$ tail defines the boundary of telomeric heterochromatin. Mol Cell. 2007;28(6):1002-14.

50. Polo SE, Jackson SP. Dynamics of DNA damage response proteins at DNA breaks: a focus on protein modifications. Genes Dev. 2011;25(5):409-33.

51. Shi L, Oberdoerffer P. Chromatin dynamics in DNA double-strand break repair. Biochim Biophys Acta. 2012;1819(7):811-9.

52. Jackson SP, Bartek J. The DNA-damage response in human biology and disease. Nature. 2009;461(7267):1071-8.

53. Hoeijmakers JH. DNA damage, aging, and cancer. $\mathrm{N}$ Engl $\mathrm{J}$ Med. 2009;361(15):1475-85.

54. d'Adda di Fagagna F. Living on a break: cellular senescence as a DNAdamage response. Nat Rev Cancer. 2008;8(7):512-22.

55. Lindahl T, Barnes DE. Repair of endogenous DNA damage. Cold Spring Harb Symp Quant Biol. 2000;65:127-33.

56. Hoeijmakers $\mathrm{JH}$. Genome maintenance mechanisms for preventing cancer. Nature. 2001;411(6835):366-74.

57. Bruner SD, Norman DP, Verdine GL. Structural basis for recognition and repair of the endogenous mutagen 8-oxoguanine in DNA. Nature. 2000;403(6772):859-66.

58. Caldecott KW. Single-strand break repair and genetic disease. Nat Rev Genet. 2008;9(8):619-31.

59. Ciccia A, Elledge SJ. The DNA damage response: making it safe to play with knives. Mol Cell. 2010;40(2):179-204.

60. Fu D, Calvo JA, Samson LD. Balancing repair and tolerance of DNA damage caused by alkylating agents. Nat Rev Cancer. 2012;12(2):104-20.

61. Sutherland BM, Oliver R, Fuselier CO, Sutherland JC. Photoreactivation of pyrimidine dimers in the DNA of normal and xeroderma pigmentosum cells. Biochemistry. 1976;15(2):402-6.

62. Zhang M, Wang L, Zhong D. Photolyase: Dynamics and electron-transfer mechanisms of DNA repair. Arch Biochem Biophys. 2017;632:158-74.

63. Nouspikel T. DNA repair in mammalian cells : Nucleotide excision repair: variations on versatility. Cell Mol Life Sci. 2009;66(6):994-1009.

64. Jiricny J. The multifaceted mismatch-repair system. Nat Rev Mol Cell Biol. 2006;7(5):335-46.

65. Bassing $\mathrm{CH}$, Alt FW. The cellular response to general and programmed DNA double strand breaks. DNA Repair (Amst). 2004;3(8-9):781-96.

66. Richardson C, Horikoshi N, Pandita TK. The role of the DNA double-strand break response network in meiosis. DNA Repair (Amst). 2004;3(8-9):1149-64.

67. van Attikum H, Gasser SM. The histone code at DNA breaks: a guide to repair? Nat Rev Mol Cell Biol. 2005;6(10):757-65.

68. Bekker-Jensen S, Mailand N. Assembly and function of DNA double-strand break repair foci in mammalian cells. DNA Repair (Amst). 2010;9(12):121928.

69. Deem AK, Li X, Tyler JK. Epigenetic regulation of genomic integrity. Chromosoma. 2012;121(2):131-51. 
70. Price BD, D'Andrea AD. Chromatin remodeling at DNA double-strand breaks. Cell. 2013;152(6):1344-54.

71. Chen QY, Costa M, Sun $H$. Structure and function of histone acetyltransferase MOF. AIMS Biophys. 2015;2(4):555-69.

72. Sun $\mathrm{Y}$, Jiang $\mathrm{X}, \mathrm{Xu} \mathrm{Y}$, Ayrapetov MK, Moreau LA, Whetstine JR, et al. Histone $\mathrm{H} 3$ methylation links DNA damage detection to activation of the tumour suppressor Tip60. Nat Cell Biol. 2009;11(11):1376-82.

73. Bakkenist CJ, Kastan MB. Chromatin perturbations during the DNA damage response in higher eukaryotes. DNA Repair (Amst). 2015;36:8-12.

74. Bakkenist CJ, Kastan MB. DNA damage activates ATM through intermolecular autophosphorylation and dimer dissociation. Nature. 2003;421(6922):499-506.

75. Sun $\mathrm{Y}, \mathrm{Xu} \mathrm{Y}$, Roy K, Price BD. DNA damage-induced acetylation of lysine 3016 of ATM activates ATM kinase activity. Mol Cell Biol. 2007;27(24):85029.

76. Kozlov SV, Graham ME, Jakob B, Tobias F, Kijas AW, Tanuji M, et al. Autophosphorylation and ATM activation: additional sites add to the complexity. J Biol Chem. 2011;286(11):9107-19.

77. Kim YC, Gerlitz G, Furusawa T, Catez F, Nussenzweig A, Oh KS, et al. Activation of ATM depends on chromatin interactions occurring before induction of DNA damage. Nat Cell Biol. 2009;11(1):92-6.

78. Kaidi A, Jackson SP. KAT5 tyrosine phosphorylation couples chromatin sensing to ATM signalling. Nature. 2013;498(7452):70-4.

79. Lavin MF. ATM and the Mre11 complex combine to recognize and signal DNA double-strand breaks. Oncogene. 2007;26(56):7749-58.

80. Lamarche BJ, Orazio NI, Weitzman MD. The MRN complex in double-strand break repair and telomere maintenance. FEBS Lett. 2010;584(17):3682-95.

81. Williams GJ, Lees-Miller SP, Tainer JA. Mre11-Rad50-Nbs1 conformations and the control of sensing, signaling, and effector responses at DNA doublestrand breaks. DNA Repair (Amst). 2010;9(12):1299-306.

82. Sung S, Li F, Park YB, Kim JS, Kim AK, Song OK, et al. DNA end recognition by the Mre11 nuclease dimer: insights into resection and repair of damaged DNA. EMBO J. 2014;33(20):2422-35.

83. Yuan J, Chen J. MRE11-RAD50-NBS1 complex dictates DNA repair independent of H2AX. J Biol Chem. 2010;285(2):1097-104.

84. Rossetto D, Truman AW, Kron SJ, Cote J. Epigenetic modifications in doublestrand break DNA damage signaling and repair. Clin Cancer Res. 2010;16(18):4543-52.

85. Salzano M, Sanz-Garcia M, Monsalve DM, Moura DS, Lazo PA. VRK1 chromatin kinase phosphorylates $\mathrm{H} 2 \mathrm{AX}$ and is required for foci formation induced by DNA damage. Epigenetics. 2015;10(5):373-83.

86. Monsalve DM, Campillo-Marcos I, Salzano M, Sanz-Garcia M, Cantarero L, Lazo PA. VRK1 phosphorylates and protects NBS1 from ubiquitination and proteasomal degradation in response to DNA damage. Biochim Biophys Acta. 2016;1863(4):760-9.

87. Lavin MF, Kozlov S, Gatei M, Kijas AW. ATM-Dependent Phosphorylation of All Three Members of the MRN Complex: From Sensor to Adaptor. Biomolecules. 2015;5(4):2877-902.

88. Lou Z, Minter-Dykhouse K, Franco S, Gostissa M, Rivera MA, Celeste A, et al. MDC1 maintains genomic stability by participating in the amplification of ATM-dependent DNA damage signals. Mol Cell. 2006;21(2):187-200.

89. Liu J, Luo S, Zhao H, Liao J, Li J, Yang C, et al. Structural mechanism of the phosphorylation-dependent dimerization of the MDC1 forkhead-associated domain. Nucleic Acids Res. 2012;40(9):3898-912. 
90. Cook PJ, Ju BG, Telese F, Wang X, Glass CK, Rosenfeld MG. Tyrosine dephosphorylation of $\mathrm{H} 2 \mathrm{AX}$ modulates apoptosis and survival decisions. Nature. 2009;458(7238):591-6.

91. Rai R, Dai H, Multani AS, Li K, Chin K, Gray J, et al. BRIT1 regulates early DNA damage response, chromosomal integrity, and cancer. Cancer Cell. 2006;10(2):145-57.

92. Peng G, Lin SY. The linkage of chromatin remodeling to genome maintenance: contribution from a human disease gene BRIT1/MCPH1. Epigenetics. 2009;4(7):457-61.

93. Lan L, Ui A, Nakajima S, Hatakeyama K, Hoshi M, Watanabe R, et al. The ACF1 complex is required for DNA double-strand break repair in human cells. Mol Cell. 2010;40(6):976-87.

94. Ward IM, Minn K, Jorda KG, Chen J. Accumulation of checkpoint protein 53BP1 at DNA breaks involves its binding to phosphorylated histone H2AX. J Biol Chem. 2003;278(22):19579-82.

95. Eliezer Y, Argaman L, Rhie A, Doherty AJ, Goldberg M. The direct interaction between 53BP1 and MDC1 is required for the recruitment of 53BP1 to sites of damage. J Biol Chem. 2009;284(1):426-35.

96. Wakeman TP, Wang Q, Feng J, Wang XF. Bat3 facilitates H3K79 dimethylation by DOT1L and promotes DNA damage-induced 53BP1 foci at G1/G2 cell-cycle phases. EMBO J. 2012;31(9):2169-81.

97. Pei H, Zhang L, Luo K, Qin Y, Chesi M, Fei F, et al. MMSET regulates histone H4K20 methylation and 53BP1 accumulation at DNA damage sites. Nature. 2011;470(7332):124-8.

98. Dulev S, Tkach J, Lin S, Batada NN. SET8 methyltransferase activity during the DNA double-strand break response is required for recruitment of 53BP1. EMBO Rep. 2014;15(11):1163-74.

99. Fradet-Turcotte A, Canny MD, Escribano-Diaz C, Orthwein A, Leung CC, Huang $\mathrm{H}$, et al. 53BP1 is a reader of the DNA-damage-induced H2A Lys 15 ubiquitin mark. Nature. 2013;499(7456):50-4.

100. Lee KY, Im JS, Shibata E, Dutta A. ASF1a Promotes Non-homologous End Joining Repair by Facilitating Phosphorylation of MDC1 by ATM at DoubleStrand Breaks. Mol Cell. 2017;68(1):61-75 e5.

101. Sanz-Garcia M, Monsalve DM, Sevilla A, Lazo PA. Vaccinia-related kinase 1 (VRK1) is an upstream nucleosomal kinase required for the assembly of 53BP1 foci in response to ionizing radiation-induced DNA damage. J Biol Chem. 2012;287(28):23757-68.

102. Lee H, Kwak HJ, Cho IT, Park SH, Lee CH. S1219 residue of 53BP1 is phosphorylated by ATM kinase upon DNA damage and required for proper execution of DNA damage response. Biochem Biophys Res Commun. 2009;378(1):32-6.

103. Chapman JR, Barral P, Vannier JB, Borel V, Steger M, Tomas-Loba A, et al. RIF1 is essential for 53BP1-dependent nonhomologous end joining and suppression of DNA double-strand break resection. Mol Cell. 2013;49(5):85871.

104. Hsiao KY, Mizzen CA. Histone H4 deacetylation facilitates 53BP1 DNA damage signaling and double-strand break repair. $J$ Mol Cell Biol. 2013;5(3):157-65.

105. Vazquez BN, Thackray JK, Simonet NG, Kane-Goldsmith N, MartinezRedondo $\mathrm{P}$, Nguyen $\mathrm{T}$, et al. SIRT7 promotes genome integrity and modulates non-homologous end joining DNA repair. EMBO J. 2016;35(14):1488-503.

106. Wu Q, Paul A, Su D, Mehmood S, Foo TK, Ochi T, et al. Structure of BRCA1BRCT/Abraxas Complex Reveals Phosphorylation-Dependent BRCT Dimerization at DNA Damage Sites. Mol Cell. 2016;61(3):434-48. 
107. Chen L, Nievera CJ, Lee AY, Wu X. Cell cycle-dependent complex formation of BRCA1.CtIP.MRN is important for DNA double-strand break repair. J Biol Chem. 2008;283(12):7713-20.

108. Nakamura K, Saredi G, Becker JR, Foster BM, Nguyen NV, Beyer TE, et al. H4K20me0 recognition by BRCA1-BARD1 directs homologous recombination to sister chromatids. Nat Cell Biol. 2019;21(3):311-8.

109. Tang J, Cho NW, Cui G, Manion EM, Shanbhag NM, Botuyan MV, et al. Acetylation limits 53BP1 association with damaged chromatin to promote homologous recombination. Nat Struct Mol Biol. 2013;20(3):317-25.

110. Isono M, Niimi A, Oike T, Hagiwara Y, Sato H, Sekine R, et al. BRCA1 Directs the Repair Pathway to Homologous Recombination by Promoting 53BP1 Dephosphorylation. Cell Rep. 2017;18(2):520-32.

111. Stolz A, Ertych N, Bastians H. Tumor suppressor CHK2: regulator of DNA damage response and mediator of chromosomal stability. Clin Cancer Res. 2011;17(3):401-5.

112. Caestecker KW, Van de Walle GR. The role of BRCA1 in DNA double-strand repair: past and present. Exp Cell Res. 2013;319(5):575-87.

113. Chabalier-Taste C, Brichese L, Racca C, Canitrot Y, Calsou P, Larminat F. Polo-like kinase 1 mediates BRCA1 phosphorylation and recruitment at DNA double-strand breaks. Oncotarget. 2016;7(3):2269-83.

114. Czornak K, Chughtai S, Chrzanowska KH. Mystery of DNA repair: the role of the MRN complex and ATM kinase in DNA damage repair. J Appl Genet. 2008;49(4):383-96.

115. Misteli T, Soutoglou E. The emerging role of nuclear architecture in DNA repair and genome maintenance. Nat Rev Mol Cell Biol. 2009;10(4):243-54.

116. Pannunzio NR, Watanabe G, Lieber MR. Nonhomologous DNA end-joining for repair of DNA double-strand breaks. J Biol Chem. 2018;293(27):10512-23.

117. Hartlerode AJ, Scully R. Mechanisms of double-strand break repair in somatic mammalian cells. Biochem J. 2009;423(2):157-68.

118. Brochier C, Langley B. Chromatin modifications associated with DNA doublestrand breaks repair as potential targets for neurological diseases. Neurotherapeutics. 2013;10(4):817-30.

119. Lilley DMJ. Holliday junction-resolving enzymes-structures and mechanisms. FEBS Lett. 2017;591(8):1073-82.

120. Hanahan D, Weinberg RA. Hallmarks of cancer: the next generation. Cell. 2011;144(5):646-74.

121. O'Connor MJ, Martin NM, Smith GC. Targeted cancer therapies based on the inhibition of DNA strand break repair. Oncogene. 2007;26(56):7816-24.

122. Minchom A, Aversa C, Lopez J. Dancing with the DNA damage response: next-generation anti-cancer therapeutic strategies. Ther Adv Med Oncol. 2018;10:1758835918786658.

123. Yousefi H, Yuan J, Keshavarz-Fathi M, Murphy JF, Rezaei N. Immunotherapy of cancers comes of age. Expert Rev Clin Immunol. 2017;13(10):1001-15.

124. Ray Chaudhuri A, Nussenzweig A. The multifaceted roles of PARP1 in DNA repair and chromatin remodelling. Nat Rev Mol Cell Biol. 2017;18(10):610-21 .

125. Kotter A, Cornils K, Borgmann K, Dahm-Daphi J, Petersen C, Dikomey E, et al. Inhibition of PARP1-dependent end-joining contributes to Olaparibmediated radiosensitization in tumor cells. Mol Oncol. 2014;8(8):1616-25.

126. McMahon M, Frangova TG, Henderson CJ, Wolf CR. Olaparib, Monotherapy or with lonizing Radiation, Exacerbates DNA Damage in Normal Tissues: Insights from a New p21 Reporter Mouse. Mol Cancer Res. 2016;14(12):1195-203.

127. Fong PC, Boss DS, Yap TA, Tutt A, Wu P, Mergui-Roelvink M, et al. Inhibition of poly(ADP-ribose) polymerase in tumors from BRCA mutation carriers. $\mathrm{N}$ Engl J Med. 2009;361(2):123-34. 
128. Fong PC, Yap TA, Boss DS, Carden CP, Mergui-Roelvink M, Gourley C, et al. Poly(ADP)-ribose polymerase inhibition: frequent durable responses in BRCA carrier ovarian cancer correlating with platinum-free interval. J Clin Oncol. 2010;28(15):2512-9.

129. Williamson CT, Muzik H, Turhan AG, Zamo A, O'Connor MJ, Bebb DG, et al. ATM deficiency sensitizes mantle cell lymphoma cells to poly(ADP-ribose) polymerase-1 inhibitors. Mol Cancer Ther. 2010;9(2):347-57.

130. Kubota E, Williamson CT, Ye R, Elegbede A, Peterson L, Lees-Miller SP, et al. Low ATM protein expression and depletion of p53 correlates with olaparib sensitivity in gastric cancer cell lines. Cell Cycle. 2014;13(13):2129-37.

131. Pilie PG, Gay CM, Byers LA, O'Connor MJ, Yap TA. PARP Inhibitors: Extending Benefit Beyond BRCA-Mutant Cancers. Clin Cancer Res. 2019.

132. Hanks SK, Hunter T. Protein kinases 6. The eukaryotic protein kinase superfamily: kinase (catalytic) domain structure and classification. FASEB J. 1995;9(8):576-96.

133. Manning G, Whyte DB, Martinez R, Hunter T, Sudarsanam S. The protein kinase complement of the human genome. Science. 2002;298(5600):191234.

134. Nezu J, Oku A, Jones MH, Shimane M. Identification of two novel human putative serine/threonine kinases, VRK1 and VRK2, with structural similarity to vaccinia virus B1R kinase. Genomics. 1997;45(2):327-31.

135. Vega FM, Gonzalo P, Gaspar ML, Lazo PA. Expression of the VRK (vacciniarelated kinase) gene family of $p 53$ regulators in murine hematopoietic development. FEBS Lett. 2003;544(1-3):176-80.

136. Nichols RJ, Traktman P. Characterization of three paralogous members of the Mammalian vaccinia related kinase family. J Biol Chem. 2004;279(9):793446.

137. Park CH, Ryu HG, Kim SH, Lee D, Song H, Kim KT. Presumed pseudokinase VRK3 functions as a BAF kinase. Biochim Biophys Acta. 2015;1853(7):173848.

138. Klerkx EP, Lazo PA, Askjaer P. Emerging biological functions of the vacciniarelated kinase (VRK) family. Histol Histopathol. 2009;24(6):749-59.

139. Dhillon N, Hoekstra MF. Characterization of two protein kinases from Schizosaccharomyces pombe involved in the regulation of DNA repair. EMBO J. 1994;13(12):2777-88.

140. Ho Y, Mason S, Kobayashi R, Hoekstra M, Andrews B. Role of the casein kinase I isoform, Hrr25, and the cell cycle-regulatory transcription factor, SBF, in the transcriptional response to DNA damage in Saccharomyces cerevisiae. Proc Natl Acad Sci U S A. 1997;94(2):581-6.

141. Waters K, Yang AZ, Reinke V. Genome-wide analysis of germ cell proliferation in C.elegans identifies VRK-1 as a key regulator of CEP-1/p53. Dev Biol. 2010;344(2):1011-25.

142. Gorjanacz M, Klerkx EP, Galy V, Santarella R, Lopez-Iglesias C, Askjaer P, et al. Caenorhabditis elegans BAF-1 and its kinase VRK-1 participate directly in post-mitotic nuclear envelope assembly. EMBO J. 2007;26(1):132-43.

143. Dobrzynska A, Askjaer P. Vaccinia-related kinase 1 is required for early uterine development in Caenorhabditis elegans. Dev Biol. 2016;411(2):24656 .

144. Aihara H, Nakagawa T, Yasui K, Ohta T, Hirose S, Dhomae N, et al. Nucleosomal histone kinase-1 phosphorylates H2A Thr 119 during mitosis in the early Drosophila embryo. Genes Dev. 2004;18(8):877-88.

145. Lancaster OM, Cullen CF, Ohkura H. NHK-1 phosphorylates BAF to allow karyosome formation in the Drosophila oocyte nucleus. J Cell Biol. 2007;179(5):817-24. 
146. Zelko I, Kobayashi R, Honkakoski P, Negishi M. Molecular cloning and characterization of a novel nuclear protein kinase in mice. Arch Biochem Biophys. 1998;352(1):31-6.

147. Lopez-Borges S, Lazo PA. The human vaccinia-related kinase 1 (VRK1) phosphorylates threonine-18 within the mdm-2 binding site of the p53 tumour suppressor protein. Oncogene. 2000;19(32):3656-64.

148. Shin J, Chakraborty G, Bharatham N, Kang C, Tochio N, Koshiba S, et al. NMR solution structure of human vaccinia-related kinase 1 (VRK1) reveals the C-terminal tail essential for its structural stability and autocatalytic activity. J Biol Chem. 2011;286(25):22131-8.

149. Blanco S, Klimcakova L, Vega FM, Lazo PA. The subcellular localization of vaccinia-related kinase-2 (VRK2) isoforms determines their different effect on p53 stability in tumour cell lines. FEBS J. 2006;273(11):2487-504.

150. Scheeff ED, Eswaran J, Bunkoczi G, Knapp S, Manning G. Structure of the pseudokinase VRK3 reveals a degraded catalytic site, a highly conserved kinase fold, and a putative regulatory binding site. Structure. 2009;17(1):12838.

151. Vega FM, Sevilla A, Lazo PA. p53 Stabilization and accumulation induced by human vaccinia-related kinase 1. Mol Cell Biol. 2004;24(23):10366-80.

152. Kang TH, Park DY, Choi YH, Kim KJ, Yoon HS, Kim KT. Mitotic histone H3 phosphorylation by vaccinia-related kinase 1 in mammalian cells. Mol Cell Biol. 2007;27(24):8533-46.

153. Valbuena A, Lopez-Sanchez I, Vega FM, Sevilla A, Sanz-Garcia M, Blanco S, et al. Identification of a dominant epitope in human vaccinia-related kinase 1 (VRK1) and detection of different intracellular subpopulations. Arch Biochem Biophys. 2007;465(1):219-26.

154. Guermah M, Palhan VB, Tackett AJ, Chait BT, Roeder RG. Synergistic functions of SII and p300 in productive activator-dependent transcription of chromatin templates. Cell. 2006;125(2):275-86.

155. Andersen JS, Lam YW, Leung AK, Ong SE, Lyon CE, Lamond Al, et al. Nucleolar proteome dynamics. Nature. 2005;433(7021):77-83.

156. Santos CR, Rodriguez-Pinilla M, Vega FM, Rodriguez-Peralto JL, Blanco S, Sevilla $A$, et al. VRK1 signaling pathway in the context of the proliferation phenotype in head and neck squamous cell carcinoma. Mol Cancer Res. 2006;4(3):177-85.

157. Valbuena A, Lopez-Sanchez I, Lazo PA. Human VRK1 is an early response gene and its loss causes a block in cell cycle progression. PLoS One. 2008;3(2):e1642.

158. Valbuena A, Sanz-Garcia M, Lopez-Sanchez I, Vega FM, Lazo PA. Roles of VRK1 as a new player in the control of biological processes required for cell division. Cell Signal. 2011;23(8):1267-72.

159. Haraguchi T, Koujin T, Segura-Totten M, Lee KK, Matsuoka Y, Yoneda Y, et al. BAF is required for emerin assembly into the reforming nuclear envelope. J Cell Sci. 2001;114(Pt 24):4575-85.

160. Nichols RJ, Wiebe MS, Traktman P. The vaccinia-related kinases phosphorylate the $\mathrm{N}$ ' terminus of $\mathrm{BAF}$, regulating its interaction with DNA and its retention in the nucleus. Mol Biol Cell. 2006;17(5):2451-64.

161. Molitor TP, Traktman P. Depletion of the protein kinase VRK1 disrupts nuclear envelope morphology and leads to BAF retention on mitotic chromosomes. Mol Biol Cell. 2014;25(6):891-903.

162. Ruan Q, Wang Q, Xie S, Fang Y, Darzynkiewicz Z, Guan K, et al. Polo-like kinase 3 is Golgi localized and involved in regulating Golgi fragmentation during the cell cycle. Exp Cell Res. 2004;294(1):51-9.

163. Xie S, Wang Q, Ruan Q, Liu T, Jhanwar-Uniyal M, Guan K, et al. MEK1induced Golgi dynamics during cell cycle progression is partly mediated by Polo-like kinase-3. Oncogene. 2004;23(21):3822-9. 
164. Lopez-Sanchez I, Sanz-Garcia M, Lazo PA. Plk3 interacts with and specifically phosphorylates VRK1 in Ser342, a downstream target in a pathway that induces Golgi fragmentation. Mol Cell Biol. 2009;29(5):1189201.

165. Barcia R, Lopez-Borges S, Vega FM, Lazo PA. Kinetic properties of p53 phosphorylation by the human vaccinia-related kinase 1. Arch Biochem Biophys. 2002;399(1):1-5.

166. Valbuena A, Vega FM, Blanco S, Lazo PA. p53 downregulates its activating vaccinia-related kinase 1 , forming a new autoregulatory loop. Mol Cell Biol. 2006;26(13):4782-93.

167. Valbuena A, Castro-Obregon S, Lazo PA. Downregulation of VRK1 by p53 in response to DNA damage is mediated by the autophagic pathway. PLoS One. 2011;6(2):e17320.

168. Valbuena A, Blanco S, Vega FM, Lazo PA. The $\mathrm{C} / \mathrm{H} 3$ domain of $\mathrm{p} 300$ is required to protect VRK1 and VRK2 from their downregulation induced by p53. PLoS One. 2008;3(7):e2649.

169. Sevilla A, Santos CR, Vega FM, Lazo PA. Human vaccinia-related kinase 1 (VRK1) activates the ATF2 transcriptional activity by novel phosphorylation on Thr-73 and Ser-62 and cooperates with JNK. J Biol Chem. 2004;279(26):27458-65.

170. Sevilla A, Santos CR, Barcia R, Vega FM, Lazo PA. C-Jun phosphorylation by the human vaccinia-related kinase 1 (VRK1) and its cooperation with the $\mathrm{N}$ terminal kinase of c-Jun (JNK). Oncogene. 2004;23(55):8950-8.

171. Kang TH, Park DY, Kim W, Kim KT. VRK1 phosphorylates CREB and mediates CCND1 expression. J Cell Sci. 2008;121(Pt 18):3035-41.

172. Hans F, Dimitrov S. Histone H3 phosphorylation and cell division. Oncogene. $2001 ; 20(24): 3021-7$.

173. Costelloe T, Fitzgerald J, Murphy NJ, Flaus A, Lowndes NF. Chromatin modulation and the DNA damage response. Exp Cell Res. 2006;312(14):2677-86.

174. Hurd PJ, Bannister AJ, Halls K, Dawson MA, Vermeulen M, Olsen JV, et al. Phosphorylation of histone H3 Thr-45 is linked to apoptosis. J Biol Chem. 2009;284(24):16575-83.

175. Luijsterburg MS, van Attikum H. Chromatin and the DNA damage response: the cancer connection. Mol Oncol. 2011;5(4):349-67.

176. Prigent $\mathrm{C}$, Dimitrov S. Phosphorylation of serine 10 in histone $\mathrm{H} 3$, what for? $\mathrm{J}$ Cell Sci. 2003;116(Pt 18):3677-85.

177. Moura DS, Campillo-Marcos I, Vazquez-Cedeira M, Lazo PA. VRK1 and AURKB form a complex that cross inhibit their kinase activity and the phosphorylation of histone $\mathrm{H} 3$ in the progression of mitosis. Cell Mol Life Sci. 2018;75(14):2591-611.

178. Burma S, Chen BP, Murphy M, Kurimasa A, Chen DJ. ATM phosphorylates histone $\mathrm{H} 2 \mathrm{AX}$ in response to DNA double-strand breaks. J Biol Chem. 2001;276(45):42462-7.

179. Aihara $H$, Nakagawa $T$, Mizusaki $H$, Yoneda $M$, Kato $M$, Doiguchi $M$, et al. Histone H2A T120 Phosphorylation Promotes Oncogenic Transformation via Upregulation of Cyclin D1. Mol Cell. 2016;64(1):176-88.

180. Salzano M, Vazquez-Cedeira M, Sanz-Garcia M, Valbuena A, Blanco S, Fernandez IF, et al. Vaccinia-related kinase 1 (VRK1) confers resistance to DNA-damaging agents in human breast cancer by affecting DNA damage response. Oncotarget. 2014;5(7):1770-8.

181. Thompson LH. Recognition, signaling, and repair of DNA double-strand breaks produced by ionizing radiation in mammalian cells: the molecular choreography. Mutat Res. 2012;751(2):158-246.

182. Lopez-Sanchez I, Valbuena A, Vazquez-Cedeira M, Khadake J, Sanz-Garcia M, Carrillo-Jimenez A, et al. VRK1 interacts with p53 forming a basal complex 
that is activated by UV-induced DNA damage. FEBS Lett. 2014;588(5):692700.

183. Kiessling MK, Schuierer S, Stertz S, Beibel M, Bergling S, Knehr J, et al. Identification of oncogenic driver mutations by genome-wide CRISPR-Cas9 dropout screening. BMC Genomics. 2016;17(1):723.

184. Kim IJ, Quigley D, To MD, Pham P, Lin K, Jo B, et al. Rewiring of human lung cell lineage and mitotic networks in lung adenocarcinomas. Nat Commun. 2013;4:1701.

185. Campillo-Marcos I, Lazo PA. Implication of the VRK1 chromatin kinase in the signaling responses to DNA damage: a therapeutic target? Cell Mol Life Sci. 2018;75(13):2375-88.

186. Del Puerto-Nevado L, Marin-Arango JP, Fernandez-Acenero MJ, ArroyoManzano D, Martinez-Useros J, Borrero-Palacios A, et al. Predictive value of vrk 1 and 2 for rectal adenocarcinoma response to neoadjuvant chemoradiation therapy: a retrospective observational cohort study. BMC Cancer. 2016;16:519.

187. Liu J, Wang Y, He S, Xu X, Huang Y, Tang J, et al. Expression of vacciniarelated kinase 1 (VRK1) accelerates cell proliferation but overcomes cell adhesion mediated drug resistance (CAM-DR) in multiple myeloma. Hematology. 2016;21(10):603-12.

188. Fournier MV, Martin KJ, Kenny PA, Xhaja K, Bosch I, Yaswen P, et al. Gene expression signature in organized and growth-arrested mammary acini predicts good outcome in breast cancer. Cancer Res. 2006;66(14):7095-102.

189. Martin KJ, Patrick DR, Bissell MJ, Fournier MV. Prognostic breast cancer signature identified from 3D culture model accurately predicts clinical outcome across independent datasets. PLoS One. 2008;3(8):e2994.

190. Molitor TP, Traktman P. Molecular genetic analysis of VRK1 in mammary epithelial cells: depletion slows proliferation in vitro and tumor growth and metastasis in vivo. Oncogenesis. 2013;2:e48.

191. Mon AM, MacKinnon AC, Jr., Traktman P. Overexpression of the VRK1 kinase, which is associated with breast cancer, induces a mesenchymal to epithelial transition in mammary epithelial cells. PLoS One. 2018;13(9):e0203397.

192. Lee N, Kwon JH, Kim YB, Kim SH, Park SJ, Xu W, et al. Vaccinia-related kinase 1 promotes hepatocellular carcinoma by controlling the levels of cell cycle regulators associated with G1/S transition. Oncotarget. 2015;6(30):30130-48.

193. Huang W, Cui X, Chen Y, Shao M, Shao X, Shen Y, et al. High VRK1 expression contributes to cell proliferation and survival in hepatocellular carcinoma. Pathol Res Pract. 2016;212(3):171-8.

194. Varghese RT, Liang Y, Guan T, Franck CT, Kelly DF, Sheng Z. Survival kinase genes present prognostic significance in glioblastoma. Oncotarget. 2016;7(15):20140-51.

195. Ben Z, Gong L, Qiu Y. High expression of VRK1 is related to poor prognosis in glioma. Pathol Res Pract. 2018;214(1):112-8.

196. Li J, Wang T, Pei L, Jing J, Hu W, Sun T, et al. Expression of VRK1 and the downstream gene BANF1 in esophageal cancer. Biomed Pharmacother. 2017;89:1086-91.

197. Liu ZC, Cao K, Xiao ZH, Qiao L, Wang XQ, Shang B, et al. VRK1 promotes cisplatin resistance by up-regulating C-MYC via C-Jun activation and serves as a therapeutic target in esophageal squamous cell carcinoma. Oncotarget. 2017;8(39):65642-58.

198. Sanz-Garcia M, Vazquez-Cedeira M, Kellerman E, Renbaum P, Levy-Lahad E, Lazo PA. Substrate profiling of human vaccinia-related kinases identifies coilin, a Cajal body nuclear protein, as a phosphorylation target with neurological implications. J Proteomics. 2011;75(2):548-60. 
199. Cantarero L, Sanz-Garcia M, Vinograd-Byk H, Renbaum P, Levy-Lahad E, Lazo PA. VRK1 regulates Cajal body dynamics and protects coilin from proteasomal degradation in cell cycle. Sci Rep. 2015;5:10543.

200. Renbaum P, Kellerman E, Jaron R, Geiger D, Segel R, Lee M, et al. Spinal muscular atrophy with pontocerebellar hypoplasia is caused by a mutation in the VRK1 gene. Am J Hum Genet. 2009;85(2):281-9.

201. Gonzaga-Jauregui C, Lotze T, Jamal L, Penney S, Campbell IM, Pehlivan D, et al. Mutations in VRK1 associated with complex motor and sensory axonal neuropathy plus microcephaly. JAMA Neurol. 2013;70(12):1491-8.

202. Vinograd-Byk H, Sapir T, Cantarero L, Lazo PA, Zeligson S, Lev D, et al. The spinal muscular atrophy with pontocerebellar hypoplasia gene VRK1 regulates neuronal migration through an amyloid-beta precursor proteindependent mechanism. J Neurosci. 2015;35(3):936-42.

203. Najmabadi H, Hu H, Garshasbi M, Zemojtel T, Abedini SS, Chen W, et al. Deep sequencing reveals 50 novel genes for recessive cognitive disorders. Nature. 2011;478(7367):57-63.

204. Nguyen TP, Biliciler S, Wiszniewski W, Sheikh K. Expanding Phenotype of VRK1 Mutations in Motor Neuron Disease. J Clin Neuromuscul Dis. 2015;17(2):69-71.

205. Stoll M, Teoh H, Lee J, Reddel S, Zhu Y, Buckley M, et al. Novel motor phenotypes in patients with VRK1 mutations without pontocerebellar hypoplasia. Neurology. 2016;87(1):65-70.

206. Feng SY, Li LY, Feng SM, Zou ZY. A novel VRK1 mutation associated with recessive distal hereditary motor neuropathy. Ann Clin Transl Neurol. 2019;6(2):401-5.

207. Wiebe MS, Nichols RJ, Molitor TP, Lindgren JK, Traktman P. Mice deficient in the serine/threonine protein kinase VRK1 are infertile due to a progressive loss of spermatogonia. Biol Reprod. 2010;82(1):182-93.

208. Choi YH, Park CH, Kim W, Ling H, Kang A, Chang MW, et al. Vacciniarelated kinase 1 is required for the maintenance of undifferentiated spermatogonia in mouse male germ cells. PLoS One. 2010;5(12):e15254.

209. Schober CS, Aydiner F, Booth CJ, Seli E, Reinke V. The kinase VRK1 is required for normal meiotic progression in mammalian oogenesis. Mech Dev. 2011;128(3-4):178-90.

210. Kim J, Choi YH, Chang S, Kim KT, Je JH. Defective folliculogenesis in female mice lacking Vaccinia-related kinase 1. Sci Rep. 2012;2:468.

211. Riggi N, Knoechel B, Gillespie SM, Rheinbay E, Boulay G, Suva ML, et al. EWS-FLI1 utilizes divergent chromatin remodeling mechanisms to directly activate or repress enhancer elements in Ewing sarcoma. Cancer Cell. 2014;26(5):668-81.

212. Takahashi K, Yamanaka S. Induction of pluripotent stem cells from mouse embryonic and adult fibroblast cultures by defined factors. Cell. 2006;126(4):663-76.

213. Moura DS, Fernandez IF, Marin-Royo G, Lopez-Sanchez I, Martin-Doncel E, Vega FM, et al. Oncogenic Sox2 regulates and cooperates with VRK1 in cell cycle progression and differentiation. Sci Rep. 2016;6:28532.

214. Kim W, Chakraborty G, Kim S, Shin J, Park CH, Jeong MW, et al. Macro histone H2A1.2 (macroH2A1) protein suppresses mitotic kinase VRK1 during interphase. J Biol Chem. 2012;287(8):5278-89.

215. Park CH, Choi BH, Jeong MW, Kim S, Kim W, Song YS, et al. Protein kinase Cdelta regulates vaccinia-related kinase 1 in DNA damage-induced apoptosis. Mol Biol Cell. 2011;22(8):1398-408.

216. Sanz-Garcia M, Lopez-Sanchez I, Lazo PA. Proteomics identification of nuclear Ran GTPase as an inhibitor of human VRK1 and VRK2 (vacciniarelated kinase) activities. Mol Cell Proteomics. 2008;7(11):2199-214. 
217. Vazquez-Cedeira M, Barcia-Sanjurjo I, Sanz-Garcia M, Barcia R, Lazo PA. Differential inhibitor sensitivity between human kinases VRK1 and VRK2. PLoS One. 2011;6(8):e23235.

218. Kim YS, Kim SH, Shin J, Harikishore A, Lim JK, Jung Y, et al. Luteolin suppresses cancer cell proliferation by targeting vaccinia-related kinase 1. PLoS One. 2014;9(10):e109655.

219. Kim SH, Ryu HG, Lee J, Shin J, Harikishore A, Jung HY, et al. Ursolic acid exerts anti-cancer activity by suppressing vaccinia-related kinase 1-mediated damage repair in lung cancer cells. Sci Rep. 2015;5:14570.

220. Shechter D, Dormann HL, Allis CD, Hake SB. Extraction, purification and analysis of histones. Nat Protoc. 2007;2(6):1445-57.

221. Towbin H, Staehelin T, Gordon J. Electrophoretic transfer of proteins from polyacrylamide gels to nitrocellulose sheets: procedure and some applications. Proc Natl Acad Sci U S A. 1979;76(9):4350-4.

222. Hoebeke J, Van Nijen G, De Brabander M. Interaction of oncodazole (R 17934), a new antitumoral drug, with rat brain tubulin. Biochem Biophys Res Commun. 1976;69(2):319-24.

223. Lazo PA. Reverting p53 activation after recovery of cellular stress to resume with cell cycle progression. Cell Signal. 2017;33:49-58.

224. Xu Y, Price BD. Chromatin dynamics and the repair of DNA double strand breaks. Cell Cycle. 2011;10(2):261-7.

225. Shogren-Knaak M, Ishii H, Sun JM, Pazin MJ, Davie JR, Peterson CL. Histone H4-K16 acetylation controls chromatin structure and protein interactions. Science. 2006;311(5762):844-7.

226. Krishnan V, Chow MZ, Wang Z, Zhang L, Liu B, Liu X, et al. Histone H4 lysine 16 hypoacetylation is associated with defective DNA repair and premature senescence in Zmpste24-deficient mice. Proc Natl Acad Sci U S A. 2011;108(30):12325-30.

227. Greiner D, Bonaldi T, Eskeland R, Roemer E, Imhof A. Identification of a specific inhibitor of the histone methyltransferase SU(VAR)3-9. Nat Chem Biol. 2005;1(3):143-5.

228. Rose NR, Woon EC, Kingham GL, King ON, Mecinovic J, Clifton IJ, et al. Selective inhibitors of the JMJD2 histone demethylases: combined nondenaturing mass spectrometric screening and crystallographic approaches. J Med Chem. 2010;53(4):1810-8.

229. He J, Chen X, Li B, Zhou W, Xiao J, He K, et al. Chaetocin induces cell cycle arrest and apoptosis by regulating the ROS-mediated ASK-1/JNK signaling pathways. Oncol Rep. 2017;38(4):2489-97.

230. Isham CR, Tibodeau JD, Jin W, Xu R, Timm MM, Bible KC. Chaetocin: a promising new antimyeloma agent with in vitro and in vivo activity mediated via imposition of oxidative stress. Blood. 2007;109(6):2579-88.

231. Bonenfant D, Towbin H, Coulot M, Schindler P, Mueller DR, van Oostrum J. Analysis of dynamic changes in post-translational modifications of human histones during cell cycle by mass spectrometry. Mol Cell Proteomics. 2007;6(11):1917-32.

232. Robey RW, Chakraborty AR, Basseville A, Luchenko V, Bahr J, Zhan Z, et al. Histone deacetylase inhibitors: emerging mechanisms of resistance. Mol Pharm. 2011;8(6):2021-31.

233. Bhatt S, Ashlock BM, Toomey NL, Diaz LA, Mesri EA, Lossos IS, et al. Efficacious proteasome/HDAC inhibitor combination therapy for primary effusion lymphoma. J Clin Invest. 2013;123(6):2616-28.

234. Connolly RM, Rudek MA, Piekarz R. Entinostat: a promising treatment option for patients with advanced breast cancer. Future Oncol. 2017;13(13):1137-48.

235. Bowers EM, Yan G, Mukherjee C, Orry A, Wang L, Holbert MA, et al. Virtual ligand screening of the p300/CBP histone acetyltransferase: identification of a selective small molecule inhibitor. Chem Biol. 2010;17(5):471-82. 
236. Ghizzoni M, Wu J, Gao T, Haisma HJ, Dekker FJ, George Zheng Y. 6alkylsalicylates are selective Tip60 inhibitors and target the acetyl-CoA binding site. Eur J Med Chem. 2012;47(1):337-44.

237. Mouw KW, Goldberg MS, Konstantinopoulos PA, D'Andrea AD. DNA Damage and Repair Biomarkers of Immunotherapy Response. Cancer Discov. 2017;7(7):675-93.

238. Carrassa L, Damia G. DNA damage response inhibitors: Mechanisms and potential applications in cancer therapy. Cancer Treat Rev. 2017;60:139-51.

239. Lord CJ, Ashworth A. The DNA damage response and cancer therapy. Nature. 2012;481(7381):287-94.

240. Boeing S, Williamson L, Encheva V, Gori I, Saunders RE, Instrell R, et al. Multiomic Analysis of the UV-Induced DNA Damage Response. Cell Rep. 2016;15(7):1597-610.

241. Gupta A, Hunt CR, Hegde ML, Chakraborty S, Chakraborty S, Udayakumar $\mathrm{D}$, et al. MOF phosphorylation by ATM regulates 53BP1-mediated doublestrand break repair pathway choice. Cell Rep. 2014;8(1):177-89.

242. Xu Y, Liao R, Li N, Xiang R, Sun P. Phosphorylation of Tip60 by p38alpha regulates p53-mediated PUMA induction and apoptosis in response to DNA damage. Oncotarget. 2014;5(24):12555-72.

243. Ghobashi AH, Kamel MA. Tip60: updates. J Appl Genet. 2018;59(2):161-8.

244. Lemercier C, Legube G, Caron C, Louwagie M, Garin J, Trouche D, et al. Tip60 acetyltransferase activity is controlled by phosphorylation. J Biol Chem. 2003;278(7):4713-8.

245. Germano G, Lamba S, Rospo G, Barault L, Magri A, Maione F, et al. Inactivation of DNA repair triggers neoantigen generation and impairs tumour growth. Nature. 2017;552(7683):116-20.

246. Chae YK, Anker JF, Bais P, Namburi S, Giles FJ, Chuang JH. Mutations in DNA repair genes are associated with increased neo-antigen load and activated $T$ cell infiltration in lung adenocarcinoma. Oncotarget. 2018;9(8):7949-60.

247. Fedorov O, Marsden B, Pogacic V, Rellos P, Muller S, Bullock AN, et al. A systematic interaction map of validated kinase inhibitors with Ser/Thr kinases. Proc Natl Acad Sci U S A. 2007;104(51):20523-8.

248. Fedorov O, Sundstrom M, Marsden B, Knapp S. Insights for the development of specific kinase inhibitors by targeted structural genomics. Drug Discov Today. 2007;12(9-10):365-72.

249. Teng Y, luchi K, Iwasa E, Fujishiro S, Hamashima Y, Dodo K, et al. Unnatural enantiomer of chaetocin shows strong apoptosis-inducing activity through caspase-8/caspase-3 activation. Bioorg Med Chem Lett. 2010;20(17):5085-8.

250. Illner D, Zinner R, Handtke V, Rouquette J, Strickfaden H, Lanctot C, et al. Remodeling of nuclear architecture by the thiodioxoxpiperazine metabolite chaetocin. Exp Cell Res. 2010;316(10):1662-80.

251. Albiez H, Cremer M, Tiberi C, Vecchio L, Schermelleh L, Dittrich S, et al. Chromatin domains and the interchromatin compartment form structurally defined and functionally interacting nuclear networks. Chromosome Res. 2006;14(7):707-33.

252. Wiman KG, Zhivotovsky B. Understanding cell cycle and cell death regulation provides novel weapons against human diseases. J Intern Med. 2017;281(5):483-95.

253. Narita M, Nunez S, Heard E, Narita M, Lin AW, Hearn SA, et al. Rb-mediated heterochromatin formation and silencing of E2F target genes during cellular senescence. Cell. 2003;113(6):703-16.

254. Isham CR, Tibodeau JD, Bossou AR, Merchan JR, Bible KC. The anticancer effects of chaetocin are independent of programmed cell death and hypoxia, and are associated with inhibition of endothelial cell proliferation. $\mathrm{Br} \mathrm{J}$ Cancer. 2012;106(2):314-23. 
255. Ray PD, Huang BW, Tsuji Y. Reactive oxygen species (ROS) homeostasis and redox regulation in cellular signaling. Cell Signal. 2012;24(5):981-90.

256. Duan Y, Gao Y, Zhang J, Chen Y, Jiang Y, Ji J, et al. Mitochondrial aldehyde dehydrogenase 2 protects gastric mucosa cells against DNA damage caused by oxidative stress. Free Radic Biol Med. 2016;93:165-76.

257. Fan XY, Chen XY, Liu YJ, Zhong HM, Jiang FL, Liu Y. Oxidative stressmediated intrinsic apoptosis in human promyelocytic leukemia HL-60 cells induced by organic arsenicals. Sci Rep. 2016;6:29865.

258. Jorgensen S, Schotta G, Sorensen CS. Histone H4 lysine 20 methylation: key player in epigenetic regulation of genomic integrity. Nucleic Acids Res. 2013;41(5):2797-806.

259. Chaib H, Nebbioso A, Prebet T, Castellano R, Garbit S, Restouin A, et al. Anti-leukemia activity of chaetocin via death receptor-dependent apoptosis and dual modulation of the histone methyl-transferase SUV39H1. Leukemia. 2012;26(4):662-74.

260. Yokoyama Y, Hieda M, Nishioka Y, Matsumoto A, Higashi S, Kimura H, et al. Cancer-associated upregulation of histone $\mathrm{H} 3$ lysine 9 trimethylation promotes cell motility in vitro and drives tumor formation in vivo. Cancer Sci. 2013;104(7):889-95.

261. Maleszewska M, Steranka A, Kaminska B. The effects of selected inhibitors of histone modifying enzyme on C6 glioma cells. Pharmacol Rep. 2014;66(1):107-13.

262. Truitt L, Hutchinson C, DeCoteau JF, Geyer CR. Chaetocin antileukemia activity against chronic myelogenous leukemia cells is potentiated by bone marrow stromal factors and overcomes innate imatinib resistance. Oncogenesis. 2014;3:e122.

263. Lai YS, Chen JY, Tsai HJ, Chen TY, Hung WC. The SUV39H1 inhibitor chaetocin induces differentiation and shows synergistic cytotoxicity with other epigenetic drugs in acute myeloid leukemia cells. Blood Cancer J. 2015;5:e313.

264. Liu X, Guo S, Liu X, Su L. Chaetocin induces endoplasmic reticulum stress response and leads to death receptor 5-dependent apoptosis in human nonsmall cell lung cancer cells. Apoptosis. 2015;20(11):1499-507.

265. Rombo R, Weiher H, Schmidt-Wolf IG. Effect of chaetocin on renal cell carcinoma cells and cytokine-induced killer cells. Ger Med Sci. 2016;14:Doc04.

266. Han X, Han Y, Zheng Y, Sun Q, Ma T, Zhang J, et al. Chaetocin induces apoptosis in human melanoma cells through the generation of reactive oxygen species and the intrinsic mitochondrial pathway, and exerts its antitumor activity in vivo. PLoS One. 2017;12(4):e0175950.

267. Bannister AJ, Kouzarides T. Regulation of chromatin by histone modifications. Cell Res. 2011;21(3):381-95.

268. Bosch-Presegue L, Vaquero A. Sirtuin-dependent epigenetic regulation in the maintenance of genome integrity. FEBS J. 2015;282(9):1745-67.

269. Zhang R, Wang J, Zhao L, Liu S, Du D, Ding H, et al. Identification of novel inhibitors of histone acetyltransferase hMOF through high throughput screening. Eur J Med Chem. 2018;157:867-76.

270. Ruthenburg AJ, Allis CD, Wysocka J. Methylation of lysine 4 on histone H3: intricacy of writing and reading a single epigenetic mark. Mol Cell. 2007;25(1):15-30.

271. Vacik T, Ladinovic D, Raska I. KDM2A/B lysine demethylases and their alternative isoforms in development and disease. Nucleus. 2018;9(1):431-41.

272. Rasmussen PB, Staller P. The KDM5 family of histone demethylases as targets in oncology drug discovery. Epigenomics. 2014;6(3):277-86. 
273. Wang Z, Zang C, Rosenfeld JA, Schones DE, Barski A, Cuddapah S, et al. Combinatorial patterns of histone acetylations and methylations in the human genome. Nat Genet. 2008;40(7):897-903.

274. Guillemette $\mathrm{B}$, Drogaris $\mathrm{P}$, Lin $\mathrm{HH}$, Armstrong $\mathrm{H}$, Hiragami-Hamada K, Imhof $A$, et al. $\mathrm{H} 3$ lysine 4 is acetylated at active gene promoters and is regulated by H3 lysine 4 methylation. PLoS Genet. 2011;7(3):e1001354.

275. Judes G, Dubois L, Rifai K, Idrissou M, Mishellany F, Pajon A, et al. TIP60: an actor in acetylation of $\mathrm{H} 3 \mathrm{~K} 4$ and tumor development in breast cancer. Epigenomics. 2018;10(11):1415-30.

276. Rifai K, Judes G, Idrissou M, Daures M, Bignon YJ, Penault-Llorca F, et al. SIRT1-dependent epigenetic regulation of $\mathrm{H} 3$ and $\mathrm{H} 4$ histone acetylation in human breast cancer. Oncotarget. 2018;9(55):30661-78.

277. Ji H, Zhou Y, Zhuang X, Zhu Y, Wu Z, Lu Y, et al. HDAC3 deficiency promotes liver cancer through a defect in $\mathrm{H} 3 \mathrm{~K} 9 \mathrm{ac} / \mathrm{H} 3 \mathrm{~K} 9 \mathrm{me} 3$ transition. Cancer Res. 2019.

278. Rao VK, Pal A, Taneja R. A drive in SUVs: From development to disease. Epigenetics. 2017;12(3):177-86.

279. Shin S, Janknecht R. Diversity within the JMJD2 histone demethylase family. Biochem Biophys Res Commun. 2007;353(4):973-7. 

Parte del trabajo mostrado en esta tesis doctoral ha sido publicado en los siguientes artículos científicos:

Campillo-Marcos I. \& Lazo PA. Olaparib and ionizing radiation trigger a cooperative DNA-damage repair response that is impaired by depletion of the VRK1 chromatin kinase. J Exp Clin Cancer Res., 38, 203. doi: 10.1186/s13046-019-1204-1 (2019)

Campillo-Marcos I. \& Lazo PA. Implication of the VRK1 chromatin kinase in the signaling responses to DNA damage: a therapeutic target? Cell Mol Life Sci., 75, 2375-2388, doi: 10.1007/s00018-018-2811-2 (2018)

Otros trabajos en los que se ha participado y que también han sido publicados:

Moura DS., Campillo-Marcos I., Vázquez-Cedeira M. \& Lazo, PA. VRK1 and AURKB form a complex that cross inhibit their kinase activity and the phosphorylation of histone H3 in the progression of mitosis. Cell Mol Life Sci., 75, 2591-2611, doi: 10.1007/s00018-018-2746-7 (2018)

Monsalve, DM., Campillo-Marcos, I., Salzano, M., Sanz-García, M., Cantarero, L. \& Lazo, PA. VRK1 phosphorylates and protects Nbs1 from ubiquitination and proteasomal degradation in response to DNA damage. Biochim Biophys Acta. 1863, 760-769, doi: 10.1016/j.bbamcr.2016.02.005 (2016) 



\section{Agradecimientos}

No puedo terminar la escritura de esta tesis sin dar las gracias a todos aquellos que han compartido conmigo esta etapa de mi vida. En primer lugar, al profesor Pedro A. Lazo, que desde el principio confió en mí, me ofreció la oportunidad de realizar este trabajo en su laboratorio y me ayudó a crecer como científico.

A continuación, me gustaría acordarme de todos aquellos que forman parte del Centro de Investigación del Cáncer, tanto de los servicios comunes como de los distintos laboratorios. Habéis estado ahí siempre que os he necesitado y no puedo más que agradecéroslo. En este punto, quiero dar las gracias, de forma especial, a los técnicos de la unidad de microscopía: María, aunque ya no estés por aquí, Ángel, Sara y Ana. Hemos compartido muchísimas horas de trabajo, pero también de entretenimiento. Sin vosotros, esta tesis no habría sido posible y sabéis que, "a pesar de todo...", os echaré de menos.

Quiero destacar también la enorme importancia que han tenido todos mis compañeros del laboratorio 4 en esta tesis, desde los que estuvieron hasta los que acaban de llegar. Gracias a Martiña y Ana Clara, importantes durante mi primer año, siempre difícil. A Diana, por estar siempre dispuesta a ayudarme aun sabiendo que tenía una tesis que escribir... Espero haber seguido bien tu ejemplo y haber cuidado como es debido del que fue tu lugar de trabajo y que a día de hoy es el mío. A Marcella, porque, a pesar de nuestros más y nuestros menos, siempre estuviste pendiente de que todo me fuera bien en el laboratorio. A Gema, por la alegría que nos transmitías a la hora de trabajar. A David, por tus buenos consejos tanto en el campo científico como en el personal. Espero que todo te vaya genial y que nos volvamos a ver pronto. A Lara... No sabría explicar con palabras lo que significas para mí. Nunca pensé, en base a la primera impresión que tuve de ti al entrar al laboratorio, que serías tan importante, no sólo en la tesis, sino en mi vida. Fuiste, eres y serás mi rubiiiii. $A$ Adrivanio, con quién compartí 6 meses y que me mostró lo importante que es la informática para el análisis de datos. iiiCuánto tiempo me habría ahorrado si hubieses llegado antes!!! A Abel, por todo lo bueno que hemos pasado dentro y fuera del laboratorio. A Elena, la artista del grupo, que ha estado conmigo desde que inicié mi 
andadura en Salamanca y con la que he tenido el placer de compartir momentos inolvidables. Me resultará difícil entrar a un nuevo laboratorio y no verte por ahí. $A$ Raúl, mi "pupilo", por dejar que te enseñase lo poco que sabía cuando llegaste y por ayudarme con la tesis, sobre todo, en este último tramo. Espero que vayas tomando nota para la tuya. A Helena, mi segunda "alumna", siempre dispuesta a ayudar y a aprender cosas nuevas. Es estupendo trabajar contigo. A Patri... Has sido una gran compañera de pasillo en el laboratorio, aunque me queje continuamente de tus despistes, y que sepas que echaré de menos que alguien me llame Ignacio, porque Nacho no le gusta. Y por último, pero no menos importante, a Eugenia y Eva, por vuestra simpatía y apoyo en estos últimos compases de la tesis iiiGracias a todos por ser mi pequeña gran familia en el CIC!!!

Además de los amigos que me llevo del laboratorio 4, otros muchos se han unido a la lista, bien por trabajar en el CIC, o bien por formar parte de mi vida en Salamanca. Me resulta difícil nombraros a todos, por lo que mencionaré a algunos de vosotros en representación del resto: Ari, Vane, Laura/s, Lucía/s, Arturo, JAM, Rubén, Blanca, Sonia/s, Natalia/s... Todos, de alguna manera, me habéis ayudado a crecer como persona y habéis hecho de la tesis una época única. También a Laura, Diego y Ester. A pesar de la distancia, os siento cerca y me alegro de que forméis parte de esta historia. En este apartado, no puedo olvidarme de mis amigos de La Bañeza, tanto los que viven en Salamanca como los que están en otros lugares. Gracias por acompañarme durante este camino.

Antes de terminar y, para no alargarme demasiado, me gustaría dar las gracias de manera particular a Bea. Has sido un apoyo constante e incondicional durante estos últimos años y siempre has estado a mi lado a pesar de las trabas del camino. Espero y deseo que esta tesis sea uno de los muchos logros que consigamos juntos.

Ya para finalizar, reservo mis últimas palabras para mi familia $y$, en especial, para mis padres. Habéis sido siempre mi mayor pilar, los que habéis confiado en mí incluso cuando ni siquiera yo lo hacía y habéis hecho posible que mis sueños se vayan cumpliendo. Todo lo que he conseguido hasta ahora os lo debo a vosotros y os merecéis un GRACIAS con mayúsculas. 

